\title{
As espécies do gênero Ceresa Amyot \& Serville (Hemiptera, Auchenorrhyncha, Membracidae)
}

\author{
Gabriel Simões de Andrade
}

Centro de Ciências Biológicas e da Saúde, Universidade Estadual do Oeste do Paraná. Rua Universitária 2069, Caixa Postal

711, 85819-110 Cascavel, Paraná, Brasil. E-mail: gsa@certto.com.br

ABSTRACT. The species of the genus Ceresa Amyot \& Serville (Hemiptera,Auchenorrhyncha, Membracidae). A revision of the genus Ceresa Amyot \& Serville, 1843 is presented. Thirty-four species are recognized as valid, each one described and illustrated, five of which are revalidated: $C$. abbreviata Andrade, 1989, C. albosignata RemesLenicov, 1973, C. amazonica Andrade, 2002, C. atrata Remes-Lenicov, 1973, C. axillaris (Germar, 1835), C. brunnicornis (Germar, 1835), C. calosa Andrade, 2002, C. cavicornis Stål, 1859, C. chacoana Remes-Lenicov, 1973, C. cuprea Funkhouser, 1927, C. denticulata Andrade, 2002, C. distans Butler, 1877 sp. rev., C. fasciatithorax Remes-Lenicov, 1973, C. maculipennis Remes-Lenicov, 1973, C. malina (Germar, 1835), C. mulsa Remes-Lenicov, 1973, C. nigripectus Remes-Lenicov, 1973, C. paranaensis Remes-Lenicov, 1976, C. paulistana Remes-Lenicov, 1976, C. pauperata Berg, 1883 sp. rev., C. piramidalis RemesLenicov, 1973, C. platycera Remes-Lenicov, 1973, C. plaumanni Sakakibara, 1977, C. projecta Funkhouser, 1927 sp. rev., C. prosocera Remes-Lenicov, 1973, C. remeslenicovae Andrade, 2002, C. rufescens Butler, 1877 sp. rev., C. similis Andrade, 1989, C. spinifera Fairmaire, 1846 sp. rev., C. stylata Remes-Lenicov, 1973, C. uruguayensis Berg, 1883, C. ustulata Fairmaire, 1846, C. viridilineata Funkhouser, 1943 and C. vitulus (Fabricius, 1775). C. excisa Walker, 1858 syn. rev. is convalidated as a junior synonym of $C$. vitulus (Fabricius, 1775) and the following new synonymies are proposed: $C$. peruensis Remes-Lenicov, 1973 syn. nov. $=$ C. distans Butler, 1877, C. alboguttata Remes-Lenicov, 1973 syn. nov. $=$ C. rufescens Butler, 1877 and $C$. insignis Walker, 1858 syn. nov. = C. ustulata Fairmaire, 1846. $C$. jugifera Goding is discussed as nomen dubium and $C$. conica Sakakibara as incertae sedis. Lectotypes are designated for $C$. pauperata Berg, $1883, C$. spinifera Fairmaire, 1846 and $C$. uruguayensis Berg, 1883. The geographical distribution of the genus is confirmed as being exclusively Neotropical, with records from the department of Quezaltenango, Guatemala, up to the province of Rio Negro, Argentina.

KEY WORDS. Ceresini, Membracoidea, Smiliinae, systematics, taxonomy.

RESUMO. É apresentada revisão do gênero Ceresa Amyot \& Serville, 1843. Trinta e quatro espécies são reconhecidas como válidas, cada qual descrita e ilustrada, cinco das quais são revalidadas: C. abbreviata Andrade, 1989, $C$. albosignata Remes-Lenicov, 1973, C. amazonica Andrade, 2002, C. atrata Remes-Lenicov, 1973, C. axillaris (Germar, 1835), C. brunnicornis (Germar, 1835), C. calosa Andrade, 2002, C. cavicornis Stål, 1859, C. chacoana Remes-Lenicov, 1973, C. cuprea Funkhouser, 1927, C. denticulata Andrade, 2002, C. distans Butler, 1877 sp. rev., C. fasciatithorax Remes-Lenicov, 1973, C. maculipennis Remes-Lenicov, 1973, C. malina (Germar, 1835), C. mulsa Remes-Lenicov, 1973, C. nigripectus RemesLenicov, 1973, C. paranaensis Remes-Lenicov, 1976, C. paulistana Remes-Lenicov, 1976, C. pauperata Berg, 1883 sp. rev., $C$. piramidalis Remes-Lenicov, 1973, C. platycera Remes-Lenicov, 1973, C. plaumanni Sakakibara, 1977, C. projecta Funkhouser, 1927 sp. rev., C. prosocera Remes-Lenicov, 1973, C. remeslenicovae Andrade, 2002, C. rufescens Butler, 1877 sp. rev., $C$. similis Andrade, 1989, C. spinifera Fairmaire, 1846 sp. rev., C. stylata Remes-Lenicov, 1973, C. uruguayensis Berg, 1883, C. ustulata Fairmaire, 1846, C. viridilineata Funkhouser, 1943 e C. vitulus (Fabricius, 1775). C. excisa Walker, 1858 syn. rev. é convalidada como sinônimo júnior de $C$. vitulus (Fabricius, 1775) e as seguintes novas sinonímias são propostas: $C$. peruensis Remes-Lenicov, 1973 syn. nov. $=$ C. distans Butler, 1877, C. alboguttata Remes-Lenicov, 1973 syn. nov. $=C$. rufescens Butler, 1877 e $C$. insignis Walker, 1858 syn. nov. = C. ustulata Fairmaire, 1846. C. jugifera Goding é discutida como nomen dubium e $C$. conica Sakakibara como incertae sedis. Lectótipos são designados para $C$. pauperata Berg, 1883, C. spinifera Fairmaire, 1846 e C. uruguayensis Berg, 1883. A distribuição geográfica do gênero é confirmada como sendo exclusivamente Neotropical, com registros desde o departamento de Quezaltenango, Guatemala, até a província de Rio Negro, Argentina.

PALAVRAS CHAVE. Ceresini, Membracoidea, sistemática, Smiliinae, taxonomia. 


\section{SUMÁRIO}

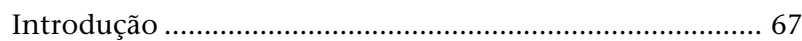

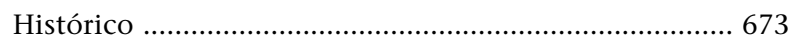

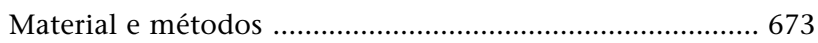

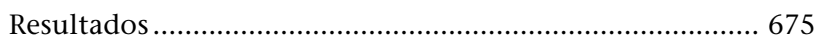

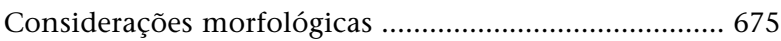

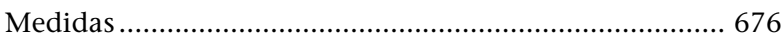

Ceresa Amyot \& Serville, 1843 ..........................................6 676

Chave para identificação das espécies ............................ 678

Ceresa abbreviata Andrade, 1989 .................................... 682

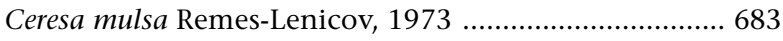

Ceresa amazonica Andrade, 2002 ...................................... 685

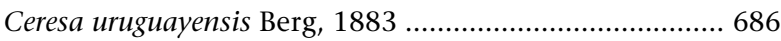

Ceresa pauperata Berg, 1883 sp. rev. .............................. 688

Ceresa axillaris (Germar, 1835) ....................................... 689

Ceresa stylata Remes-Lenicov, 1973 ............................... 690

Ceresa distans Butler, 1877 sp. rev. .................................... 692

Ceresa ustulata Fairmaire, 1846 ........................................ 694

Ceresa projecta Funkhouser, 1927 sp. rev....................... 696

Ceresa platycera Remes-Lenicov, 1973 ............................ 698

Ceresa piramidalis Remes-Lenicov, 1973 ........................ 699

Ceresa atrata Remes-Lenicov, 1973 .................................. 699

Ceresa cavicornis Stål, 1859 ............................................ 701

Ceresa prosocera Remes-Lenicov, 1973 ........................... 702

Ceresa brunnicornis (Germar, 1835) ................................. 703

Ceresa cuprea Funkhouser, 1927 ..................................... 705

Ceresa nigripectus Remes-Lenicov, 1973 ......................... 706

Ceresa maculipennis Remes-Lenicov, 1973 ..................... 709

Ceresa paulistana Remes-Lenicov, 1976 ......................... 710

Ceresa paranaensis Remes-Lenicov, 1976 ....................... 712

Ceresa malina (Germar, 1835) .......................................... 714

Ceresa plaumanni Sakakibara, 1977 ............................... 715

Ceresa denticulata Andrade, 2002 ................................... 718

Ceresa vitulus (Fabricius, 1775) .................................... 719

Ceresa albosignata Remes-Lenicov, 1973 ........................ 722

Ceresa spinifera Fairmaire, 1846 sp. rev. ....................... 723

Ceresa viridilineata Funkhouser, 1943 ........................... 724

Ceresa fasciatithorax Remes-Lenicov, 1973 .................... 726

Ceresa similis Andrade, 1989 ....................................... 727

Ceresa rufescens Butler, 1877 sp. rev. ............................. 728

Ceresa calosa Andrade, 2002 ............................................ 730

Ceresa chacoana Remes-Lenicov, 1973 ........................... 731

Ceresa remeslenicovae Andrade, 2002 ............................. 732

Ceresa jugifera Goding, 1929 nom. dub. ....................... 734

Ceresa conica Sakakibara, 1977 ........................................ 734

Vestistilus affinis (Fairmaire, 1846) comb. nov. ............. 735

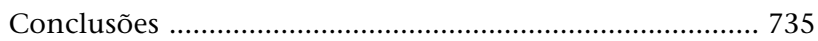

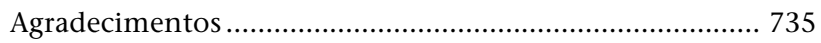

Referências bibliográficas ............................................... 736
A identificação das espécies incluídas no gênero Ceresa Amyot \& Serville, 1843, assim como das de muitos outros gêneros da família Membracidae, constitui-se em uma empreitada difícil. Kopp \& YonKe (1979), ao tratarem deste gênero, escreveram: "Due to the extent of the suprahumeral horns in the Ceresini, there have been more than 125 specific names associated with the genus Ceresa since it was erected (Metcalf \& Wade, 1965)...".

O estado caótico em que se encontra o reconhecimento das espécies associadas ao gênero Ceresa deve-se em grande parte à exigüidade das descrições dos autores pioneiros, falta de ilustrações em publicações originais e subseqüentes, identificações e interpretações errôneas, inacessibilidade aos tipos, indisponibilidade de material para estudo e limitações de escopo geográfico.

O objetivo do presente estudo é a revisão do gênero Ceresa Amyot \& Serville, 1843, seguindo métodos tradicionais em uso na sistemática.

O ponto de partida para a presente contribuição foi o catálogo de Metcalf \& WADE (1965), onde são reconhecidas como válidas 25 espécies para o gênero Ceresa. Depois desse trabalho, apenas mais duas contribuições relevantes foram publicadas: a de Remes-Lenicov (1973), que revisou o gênero Ceresa, reconhecendo 14 espécies descritas anteriormente e descrevendo 13 espécies como novas, e a de Kopp \& Yonke (1979), que revisaram a tribo Ceresini e que, ao tratar do gênero Ceresa, admitiram como válidas apenas 20 espécies, mais da metade seguindo o arranjo proposto por MEtCALF \& WADE (1965), mas que omitiram a contribuição de Remes-Lenicov (1973).

O presente trabalho não tem a pretensão de criticar as contribuições anteriores e nem a de esgotar o assunto, mas apenas a de apresentar novos subsídios para o conhecimento do gênero Ceresa e afins. Foi dada atenção especial ao exame de tantos tipos, diapositivos ou fotografias de tipos quanto possível, investigação das sinonímias até então propostas, precisão das localidades-tipo, distribuição geográfica, utilização de novos caracteres e a padronização das descrições e ilustrações, de forma a permitir um maior grau de fidedignidade e comparabilidade para as diferentes espécies.

Foram omitidas as informações da publicação de Lichtenstein (1796), a qual, segundo Deitz \& Kopp (1987), “... [gives first binominal names to various membracids illustrated by Stoll 1788a; this work was unknown to Z.P. Metcalf]". Optou-se por considerar a colocação de McKAMEY (1998), “...The work by Lichtenstein (1796a), which was unknown to Z.P. Metcalf and first bibliographed for Membracoidea by Deitz \& Kopp (1987a), gave several new names for species illustrated by Stoll (1788a). Nevertheless, Lichtenstein's (1796a) 'book' is apparently a sales catalogue for specimens to be sold at an auction rather than a work intended for permanent scientific record, so it fails to meet the criterion of publication [ICZN Art. 8a (1)]; nomenclatural acts therein are ignored in this catalogue...". 


\section{Histórico}

O gênero Ceresa foi descrito por АмYOT \& SERVILle em 1843 para acomodar duas espécies, uma das quais, Membracis vitulus Fabricius, 1775, permanece até hoje como espécie válida e, por designação subseqüente, é a espécie-tipo do gênero.

Durante o século seguinte muitas contribuições foram publicadas, incluindo descrições de novas espécies, propondo sinonímias, sugerindo novas combinações, tratando da distribuição geográfica, informando sobre plantas hospedeiras, contribuindo para o conhecimento do grupo como um todo ou simplesmente catalogando as espécies. Merecem destaque, nesse período, os trabalhos de Fairmaire (1846), Walker (1851, 1858a, b), STÅL (1859, 1867, 1869a, b), Butler (1877), Berg (1883), Fowler (1895), FunKHouser (1914, 1927a, b, 1943) e Goding (1929).

A publicação de Caldwell (1949) foi a primeira a apresentar contribuições mais claras para a caracterização do gênero Ceresa e a sua distinção com os gêneros próximos, com base em caracteres da genitália masculina. Cabe ressaltar que a utilização destes caracteres foi primeiramente sugerida por FowLER (1895) e efetivamente utilizada, com resultados satisfatórios, por Lawson (1922). A contribuição de CALDWEll (1949) estabelece para o gênero Ceresa uma distribuição exclusivamente Neotropical e transfere várias espécies neárticas e da América Central, antes nele incluídas, para outros gêneros previamente caracterizados ou para outros propostos como novos.

Na década seguinte, aparece a importante contribuição de Funkhouser (1951), o $208^{\circ}$ fascículo da obra Genera Insectorum. O gênero Ceresa foi tratado nessa publicação sem levar em consideração o arranjo proposto por CALDwell (1949). Segundo Kopp \& YONKe (1979), “...Funkhouser's (1951) manuscript, which was completed in 1938, lay in a vault in war-torn Europe from that time till its publication in 1951, several years after the death of the author. Consequently, the 5 genera described by Caldwell (1949) are not included.".

Metcalf \& Wade (1965) publicaram um necessário e indispensável suplemento ao catálogo de FunkHouser (1927b). Nesse trabalho, ora acrítico, ora propondo modificações substanciais, não somente para o gênero Ceresa, mas para toda a família Membracidae e afins, podem ser levantadas quase todas as contribuições publicadas até o ano de 1955. Após o enfoque de Metcalf \& Wade (1965), pouco foi publicado abordando aspectos de sistemática com relação ao gênero Ceresa.

Broomfield (1971) catalogou os tipos de Membracidae depositados no "British Museum (Natural History)", incluindo, portanto, os das espécies do gênero Ceresa descritas por F. Walker, A.G. Butler e W.W. Fowler. Remes-Lenicov (1973) apresentou uma revisão do gênero, na qual fez sua recaracterização e incluiu dados sobre sua posição sistemática, biologia, danos, distribuição geográfica e sinonímias. Tratou de 27 espécies, das quais 13 descritas como novas. Em 1976, essa mesma autora acrescentou mais duas novas espécies ao gênero. DeiTz (1975) fez referência e ilustrou a espécie-tipo do gênero Ceresa, ao caracterizar a tribo Ceresini em seu estudo sobre a classificação dos Membracidae do novo mundo. Kopp \& YONKE (1977) publicaram um artigo no qual trataram exaustivamente da situação taxonômica de C. bubalus (Fabricius, 1794), mantendo esta espécie no gênero Ceresa e concluindo que a consagrada "buffalo treehopper" da América do Norte não corresponde à mesma, propondo então uma nova classificação para tal no gênero Stictocephala Stål, 1869. SAKAKIBARA (1977) descreveu mais duas novas espécies para o gênero. Kopp \& YonKe (1979) publicaram a mais relevante contribuição desde os trabalhos de Remes-LenICOV (1973), tratando não especificamente do gênero Ceresa, mas da tribo Ceresini como um todo, onde, com uso de metodologia cladística e anagenética, propuseram novos gêneros e redefiniram os demais gêneros da tribo, inclusive Ceresa, baseando-se em grande parte nos caracteres da genitália masculina, em consonância pois com a contribuição de CALDwell (1949).

Deitz \& Kopp (1987) e Deitz (1989) elaboraram suplementos bibliográficos ao catálogo de Metcalf \& Wade (1965). O exame das referências apresentadas mostra que praticamente nada foi trabalhado a respeito da sistemática do gênero em questão desde o referido catálogo, salvo as citações mencionadas nos parágrafos anteriores. ANDRADE (1989) descreveu mais duas novas espécies para o gênero. Ainda ANDrade (1997) esclareceu a situação taxonômica da "buffalo treehopper" como Stictocephala alta (Walker, 1851) e transferiu C. bubalus para o gênero Hadrophallus Kopp \& Yonke, 1979.

MCKAMEY (1998) publicou o segundo suplemento ao catálogo de Funkhouser (1927), atualizando informações da literatura até abril de 1997. Andrade (1999a, b , c) publicou, respectivamente, a nova combinação de C. robusta Butler em Alcmeone Stål, a convalidação de C. intracta Walker em Proranus Spinola, 1850 (Cicadellidae) e o esclarecimento de Amastris stali Fowler como nomen nudum e não como interpretação alternativa de C. stalii Butler.

SAKAKIBARA (2002), ao tratar de Ilithucia Stål, transferiu $C$. extensa Walker para este gênero.

Os últimos trabalhos enfocando aspectos sobre a sistemática do gênero Ceresa, antes do presente estudo, são os de AndRADE (2002), onde são propostas quatro novas espécies para o gênero, ANDRADE (2003), onde várias espécies são transferidas para o gênero Vestistiloides Andrade, 2003, ANDRADE (2004a), onde C. colon (Germar, 1835) e C. recta Walker, 1858 são transferidas para Paraceresa Kopp \& Yonke, 1979, e ANDrade (2004b), onde C. discolor Fairmaire, 1846 e C. puncticeps Stål são transferidas para Spissistilus Caldwell, 1949.

\section{MATERIAL E MÉTODOS}

Para o presente estudo foram examinados cerca de 2.000 exemplares secos, depositados em coleções particulares ou em instituições nacionais e estrangeiras.

As siglas utilizadas, em ordem alfabética, os nomes das coleções particulares ou das instituições, por extenso, as cidades onde se localizam, e os nomes dos responsáveis pelo empréstimo do material, entre parênteses, são: BCL - Coleção

Revista Brasileira de Zoologia 21 (4): 671-738, dezembro 2004 
"Benedito Cortês Lopes", Florianópolis, Brasil (B.C. Lopes); CACS - Coleção "Carlos Alberto Campos Seabra", Rio de Janeiro, Brasil (C.A.C. Seabra); CB - Coleção "Carlos Bordón”, Maracay, Venezuela (C. Bordón); CESJF - Centro de Ensino Superior de Juiz de Fora, Juiz de Fora, Brasil (L. Krieger); CU - Cornell University, Ithaca, EUA (J.K. Liebherr); DZUP - Departamento de Zoologia, Universidade Federal do Paraná, Curitiba, Brasil (A.M. Sakakibara); ESALQ - Escola Superior de Agricultura "Luiz de Queiroz", Piracicaba, Brasil (J.R.P. Parra); FCNM - Facultad de Ciencias Naturales y Museo, La Plata, Argentina (R.A. Ronderos); FIOC - Fundação Instituto "Oswaldo Cruz", Rio de Janeiro, Brasil (O.V. Ferreira); FML - Fundación "Miguel Lillo", San Miguel de Tucumán, Argentina (M.V.A. Toledo); FMRP Faculdade de Medicina de Ribeirão Preto, Ribeirão Preto, Brasil (J.M.F. Camargo); IB - Instituto Biológico, São Paulo, Brasil (A.D. Brisolla); INPA - Instituto Nacional de Pesquisas da Amazônia, Manaus, Brasil (J.A. Rafael); LU - Lunds Universitet, Lund, Suécia (R. Danielsson); MA - Museu Anchieta, Porto Alegre, Brasil (C.M. Penz); MHNJP - Museo de História Natural "Javier Prado", Lima, Peru (P.W. Lozada); MN - Museu Nacional, Rio de Janeiro, Brasil (J. Becker, M.A. Monné); MRSN - Museo Regionale di Scienze Naturali, Torino, Itália (A. Casale); MZUSP - Museu de Zoologia da Universidade de São Paulo, São Paulo, Brasil (F.C. do Val, P.E. Vanzolini); NMNH - National Museum of Natural History, Washington, EUA (R.C. Froeschner); RBL - Coleção "Rudolf Bruno Lange", Curitiba, Brasil (R.B. Lange); UFRGS Universidade Federal do Rio Grande do Sul, Porto Alegre, Brasil (J. Grazia); UFV - Universidade Federal de Viçosa, Viçosa, Brasil (P.S.F. Ferreira); UPR - Universidad de Puerto Rico, Mayagüez, Porto Rico (J.A. Ramos) e ZM - Zoologisk Museum, København, Dinamarca (N.M. Andersen).

Foram examinados também diapositivos dos tipos de quase todas as espécies envolvidas neste estudo, os quais fazem parte do acervo do Departamento de Zoologia da Universidade Federal do Paraná, além de diapositivos e fotografias adicionais de tipos inacessíveis, depositados na Cornell University (Ithaca) e no Naturhistorisches Museum Wien (Wien), obtidas durante o desenvolvimento deste trabalho.

As seguintes siglas adicionais foram utilizadas no texto, para fazer referência a tipos não examinados ou não incluídos no material examinado do presente estudo: (BMNH) The Natural History Museum, Londres, Reino Unido; (EEAT) Estación Experimental Agrícola de Tucumán, San Miguel de Tucumán, Argentina; (MACNBR) Museo Argentino de Ciencias Naturales "Bernardino Rivadavia”, Buenos Aires, Argentina; (NR) Naturhistoriska Riksmuseet, Estocolmo, Suécia e (UM) University of Missouri, Columbia, EUA.

Os Resultados enfocam Considerações morfológicas, onde são apresentados comentários sobre a morfologia dos Membracidae em geral, destacando e ilustrando os caracteres relevantes para o gênero Ceresa e propondo nova terminologia para a caracterização e distinção das espécies do gênero, e Medidas, onde são feitas considerações sobre o uso de dados mensuráveis no estudo dos Membracidae em geral, acompanhados de caracterização e ilustrações dos que foram utilizados no presente estudo.

Ao tratar do gênero Ceresa propriamente dito são apresentadas as considerações de praxe: lista sinonímica do gênero, onde é feita referência à descrição original, ao catálogo de MEtCAlf \& WADE (1965) e às contribuições subseqüentes a este trabalho, amplitude dos dados mensuráveis, caracterizações cromática e morfológicas, comentários de natureza variada e situação entre os gêneros próximos. Ainda, chave para auxiliar na identificação das espécies, utilizando os caracteres comentados em Considerações morfológicas, e a seguir tratamento detalhado para cada uma das espécies.

Para cada uma das espécies, após a lista sinonímica, foi seguida a seguinte ordem de itens: Medidas, Descrição, Material examinado, Distribuição geográfica, Localidade-tipo, Notas sobre o(s) tipo(s), Planta(s) hospedeira(s), Comentários e ilustrações.

A lista sinonímica faz referência à descrição original e, quando existentes, a citação sobre como a espécie está relacionada no catálogo de METCALF \& WADE (1965) e/ou publicações subseqüentes. Após cada citação, entre parênteses, é informado, de forma abreviada, a natureza de cada referência. As abreviaturas são: (biol.) biologia, (cat.) catálogo, (gen.) genitália, (fem.) feminina, (masc.) masculina, (not.) notas, (list.) lista, (plant. hosp.) planta hospedeira, (tip.) tipo; (rdescr.) redescrição, (rep. tip.) repositório de tipo e (sin.) sinonímia.

As medidas foram tomadas com ocular micrométrica e convertidas em milímetros, sempre que possível sobre um exemplar macho e um exemplar fêmea, de preferência pertencentes à série-tipo de cada espécie, e não tem outra pretensão senão a de mostrar as proporções entre as diferentes espécies.

O item Descrição segue a disposição anatômica e funcional dos exemplares, isto é, cabeça, tórax e abdome, dando ênfase aos caracteres da cabeça, pronoto, tégminas e da genitália masculina. Foi feito um destaque inicial ao padrão de coloração das espécies, relevando a cor predominante e as matizes contrastantes. Estas considerações referem-se a exemplares secos, preservados em coleções entomológicas. Os caracteres morfológicos utilizados são os de uso geral entre os especialistas e os novos termos propostos em Considereções morfológicas. A omissão de informações com relação à genitália da fêmea não implica que não existam caracteres desta estrutura que possam ser úteis para a caracterização e distinção das espécies, mas, mais que uma opção, que a comprovação por estudos anteriores, além da observação de abundante material, mostrou sua pouca funcionalidade para tal, salvo se estudos posteriores, utilizando outra metodologia, venham a demonstrar sua validade neste aspecto. Para o estudo e acondicionamento da genitália foi seguida a técnica de Dennis (1952).

$\mathrm{O}$ item Material examinado foi elaborado seguindo as sugestões de Papavero \& Martins, in Papavero (1994).

Ao tratar de Distribuição geográfica, foram considerados

Revista Brasileira de Zoologia 21 (4): 671-738, dezembro 2004 
apenas os dados confiáveis da literatura e os do Material examinado. As informações são apresentadas por país, ao nível de estado ou equivalente, na ordem de norte para sul, exceto aquelas publicadas anteriormente, que aparecem em primeiro plano dentro de cada país e onde é feita menção à autoria e data da referência. Foram omitidas quase todas as informações contidas no catálogo de Metcalf \& Wade (1965), tendo em vista o fato de serem, geralmente, fundamentadas em dados da literatura e em espécies antes consideradas como sinônimas das atualmente admitidas como válidas, sem comprovação da verdadeira identidade das espécies.

O item Localidade-tipo faz menção clara ao país, estado ou equivalente e local de procedência do tipo ou, na falta destas informações, apresenta discussão sobre a provável localidade-tipo das espécies.

Sob Notas sobre o(s) tipo(s) são apresentadas informações tão detalhadas quanto possível sobre o holótipo ou lectótipo, isto é, o estado de conservação e o repositório do mesmo, ou sobre algum outro tipo disponível, no caso de inacessibilidade ao holótipo ou lectótipo. Outros exemplares de sériestipo, quando existentes, são apenas mencionados, com indicação sobre sua localização. Tendo em vista que não somente o gênero Ceresa, mas os Ceresini como um todo incluem muitas espécies crípticas, foram designados lectótipos para garantir a correta identificação de espécies. Neste item são apresentados também, conforme o caso, discussão sobre séries-tipo ou tipos confusos, comentários sobre tipos inacessíveis ou sobre aqueles cuja localização não foi possível precisar.

No item sobre Planta(s) hospedeira(s), assim como no item Distribuição geográfica, somente são apresentados os dados confiáveis da literatura e os do Material examinado, bem como eventuais informações pessoais fidedignas. Em primeiro lugar são relacionadas as informações publicadas anteriormente, com menção à autoria e data da referência e, a seguir, as informações levantadas no presente estudo. É importante ressaltar que estes dados não pretendem caracterizar qualquer espécie como praga dos vegetais mencionados, mas simplesmente informar sobre as plantas em que foram coletadas, o que poderá contribuir para possíveis estudos posteriores sobre a preferência alimentar das espécies do gênero.

Os Comentários são de natureza variada, acrescentando ou alterando informações sobre características das espécies e sua eventual variabilidade. Quando necessário, é apresentada argumentação sobre a identidade das mesmas, corroborando ou contestando publicações anteriores e, sempre que possível, relacionando-as com as espécies próximas, segundo as observações do presente estudo.

As ilustrações foram feitas sob microscópio estereoscópico WILD M5 e microscópio ótico WILD M20, com auxílio de câmara clara: cabeça, pronoto e tégmina foram desenhados com aumento de $12 \mathrm{X}$, o edeago com aumento de $100 \mathrm{X}$ e as demais estruturas da genitália com aumento de 50X. Os desenhos da morfologia externa tem por finalidade simplesmente mostrar as proporções entre as diversas estruturas e os padrões contrastantes de coloração, enquanto que os das estruturas da genitália masculina são mais precisos e confiáveis para a caracterização de cada espécie. Todas as ilustrações são originais, salvo indicação em contrário.

\section{RESULTADOS}

\section{Considerações morfológicas (Figs 1-6)}

Os Membracidae caracterizam-se por apresentarem, usualmente, um extraordinário e variado desenvolvimento do pronoto, o que tem sido utilizado por todos os autores para a caracterização das espécies. A forma e a escultura da superfície da cabeça, os caracteres das tégminas e os padrões de coloração são também de boa utilização, não somente ao nível dos táxons superiores, como também na distinção das espécies. Mais recentemente, tem sido dado um valor excepcional aos caracteres da genitália masculina, sobretudo para a distinção de espécies crípticas.

Kopp \& Yonke (1979) dividiram a tribo Ceresini em dois grupos de gêneros, com base na ornamentação pronotal. O gênero Ceresa foi situado entre aqueles cuja única ornamentação pronotal, quando existente, são os processos supra-umerais, em oposição àqueles que apresentam outras modificações substanciais na conformação do pronoto, tais como intumescimento, processos e outros caracteres que não os processos supra-umerais.

À primeira vista, o pronoto com aspecto tectiforme como o apresentado pelo gênero Ceresa e afins, aparenta não fornecer muitos caracteres úteis para a distinção das espécies. A análise mais acurada desta estrutura e o exame de abundante material mostrou que, além dos caracteres tradicionais de uso corrente entre os especialistas, é possível adicionar outros, que são propostos como novos termos neste estudo.

Seguem, abaixo, a relação e ilustrações dos termos técnicos utilizados no presente estudo para a cabeça, pronoto e tégminas, com a definição tão precisa quanto possível sobre os estados como podem se apresentar os caracteres, assim como ilustração das estruturas da genitália masculina. As estruturas da genitália masculina, bem como as da genitália feminina, sua constância e eventual variabilidade, foram objeto de estudo detalhado feito por Dennis (1960), sendo que as primeiras estão bem caracterizadas e ilustradas no trabalho de KopP \& YONKE (1979).

\section{Cabeça}

Superfície lisa, corrugada, estriada ou uma combinação destes estados. Sutura coronal atingindo a base do frontoclípeo, quando bem aparente em toda a sua extensão ou não atingindo a base do frontoclípeo, quando se esmaece na altura dos ocelos. Espaço interocelar plano ou convexo. Espaços ocelooculares planos ou deprimidos. Conformação dos lóbulos supra-antenais planos ou escavados. Margens dos lóbulos supraantenais retas, sinuosas ou arredondadas. Forma do frontoclípeo piriforme ou sublosângica. Bordos laterais da metade distal do frontoclípeo inteiros ou chanfrados. Direção da metade distal do frontoclípeo para baixo ou para trás. 


\section{Pronoto}

Pontuação homogênea, quando os pontos das partes laterais têm diâmetro igual ou subigual aos do metopídio, ou heterogênea, quando os pontos das partes laterais têm diâmetro ao menos duas vezes maior que os do metopídio. Abaulamento nas regiões adjacentes às impressões semicirculares abaulado ou não abaulado. Elevação fraca, regular ou forte (devido à subjetividade desta definição, é necessário recorrer às ilustrações para sua interpretação). Declive leve, gradual ou abrupto (devido à subjetividade desta definição, é necessário recorrer às ilustrações para sua interpretação). Constrição pré-apical constricto ou não constricto ao nível do ângulo interno das tégminas. Forma do metopídio pentagonal ou trapezoidal. Forma das impressões musculares do metopídio L invertido ou $\mathrm{V}$ invertido. Superfície dos lóbulos pós-oculares lisa, corrugada ou pontuada. Modificações dos lóbulos pós-oculares ao nível do ângulo externo dos olhos sem modificações, intumescidos, sulcados, calosos ou angulosos. Sulcos supra-umerais pouco marcados, quando as regiões supra-umerais são praticamente contíguas com os flancos dos processos supra-umerais ou bem marcados, quando as regiões supra-umerais são nitidamente abauladas e distintas dos flancos dos processos supra-umerais. Superfície das regiões supra-umerais lisa ou pontuada. Conformação dos processos supra-umerais cônicos, prismáticos ou prismáticos na metade basal e cônicos na metade distal. Conformação da metade distal dos processos supra-umerais reta ou curva. Direção dos processos supra-umerais para frente, para frente e para os lados, para os lados ou para os lados e para trás. Inclinação dos processos supra-umerais sem inclinação, para baixo ou para cima. Direção dos ápices dos processos supraumerais para os lados, para os lados e para trás ou para trás. Face dorsal dos processos supra-umerais escavada, plana ou arredondada. Face posterior dos processos supra-umerais lisa, corrugada, pontuada ou uma combinação destes estados. Espaço entre os processos supra-umerais côncavo, plano, convexo ou em forma de cumeeira. Aresta A (anterior) dos processos supra-umerais ausente, aparente ou cortante na metade distal. Aresta M (média) dos processos supra-umerais pronunciada somente na metade basal, pronunciada em toda a sua extensão, pronunciada como um intumescimento somente na metade basal ou pronunciada como um intumescimento em toda a sua extensão. Aresta $\mathrm{P}$ (posterior) dos processos supra-umerais ausente, aparente ou cortante na metade distal. Espaço anterior a aresta M normal, escavado ou intumescido. Espaço posterior a aresta $\mathrm{M}$ normal, escavado ou intumescido. Impressões semicirculares bem distintas, quando contrastantes com a pontuação das partes laterais ou pouco distintas, quando não contrastantes com a pontuação das partes laterais. Áreas semicirculares planas ou convexas. Impressão das áreas semicirculares bem impressas, quando situadas em um plano inferior ao das partes laterais ou pouco impressas, quando situadas no mesmo plano das partes laterais. Carena dorsal cortante ou arredondada a partir do ponto mais elevado. Extensão do ápice não atingindo, atingindo ou ultrapassando a altura da base da $3^{\mathrm{a}}$ célula apical das tégminas.

\section{Tégminas}

Veia R1 originando-se na $1^{\mathrm{a}}$ ou na $2^{\mathrm{a}}$ célula discoidal.

\section{Medidas (Figs 7-8)}

Não existe padronização das medidas utilizadas para a caracterização das diferentes espécies de Membracidae. Seu uso varia entre os autores e principalmente segundo a conformação pronotal apresentada pelas espécies de gêneros diferentes.

No presente estudo foram utilizadas apenas seis medidas para cada espécie, que podem ser tomadas com um grau razoável de precisão e que são de uso corrente entre os especialistas que trabalharam com o gênero Ceresa ou com outros gêneros que também apresentam o pronoto tectiforme.

A caracterização e ilustrações da forma como estas medidas foram tomadas são apresentadas a seguir, na ordem em que foram utilizadas no texto: 1) largura da cabeça em vista frontal, entre os bordos externos dos olhos; 2) comprimento da cabeça em vista frontal, entre a base do vértice e a curvatura do frontoclípeo; 3 ) distância entre os ângulos umerais em vista frontal ou dorsal, entre os extremos dos ângulos umerais; 4) distância entre os ápices dos processos supra-umerais em vista frontal ou dorsal, entre os ápices dos processos supra-umerais; 5) comprimento do pronoto em vista lateral, entre a base do metopídio e o ápice do pronoto; 6) Comprimento total em vista lateral, entre a base do metopídio e o ápice das tégminas.

\section{Ceresa Amyot \& Serville, 1843}

Ceresa Amyot \& Serville, 1843: 539; Metcalf \& Wade, 1965: 839 (cat.); Remes-Lenicov, 1973: 53, lám. I a XXIX, figs 1 a 228 (rev.); Deitz, 1975: 92, figs 26 I, 30 A, 31 Q, 33 D e 34 H (list.); Kopp \& Yonke, 1979: 23, figs 242 a 283 (rdescr., not.); McKamey, 1998: 243 (cat.).

Espécie-tipo. Membracis vitulus Fabricius, 1775, por designação subsequente (FunKHOUSER 1914).

Medidas. Mínima/máxima. Largura da cabeça: 2,16/3,68; comprimento da cabeça: 1,00/1,84; distância entre os ângulos umerais: 2,16/3,84; distância entre os ápices dos processos supra-umerais: 1,80/6,00; comprimento do pronoto: 5,25/9,52; comprimento total: 6,33/10,50.

Descrição. Coloração geral variando de amarelo-pálida a castanho-escura, uniforme ou com máculas, bandas transversais ou faixas longitudinais diferenciadas da cor predominante. Tégminas e veias variando de hialinas a ambarinas, uniformes ou mais escurecidas no terço distal, diferenciadas no limbo ou maculadas ao nível da $2^{\text {a }}$ célula apical. Região ventral do corpo e pernas com matizes variados.

Cabeça subtriangular, geralmente duas vezes mais larga que longa, com escultura variada. Margem superior arqueada. Olhos esféricos em vista frontal, ovóides em vista lateral. Ocelos eqüidistantes dos olhos e entre si, situados na altura da linha imaginária que passa pelo centro dos olhos. 

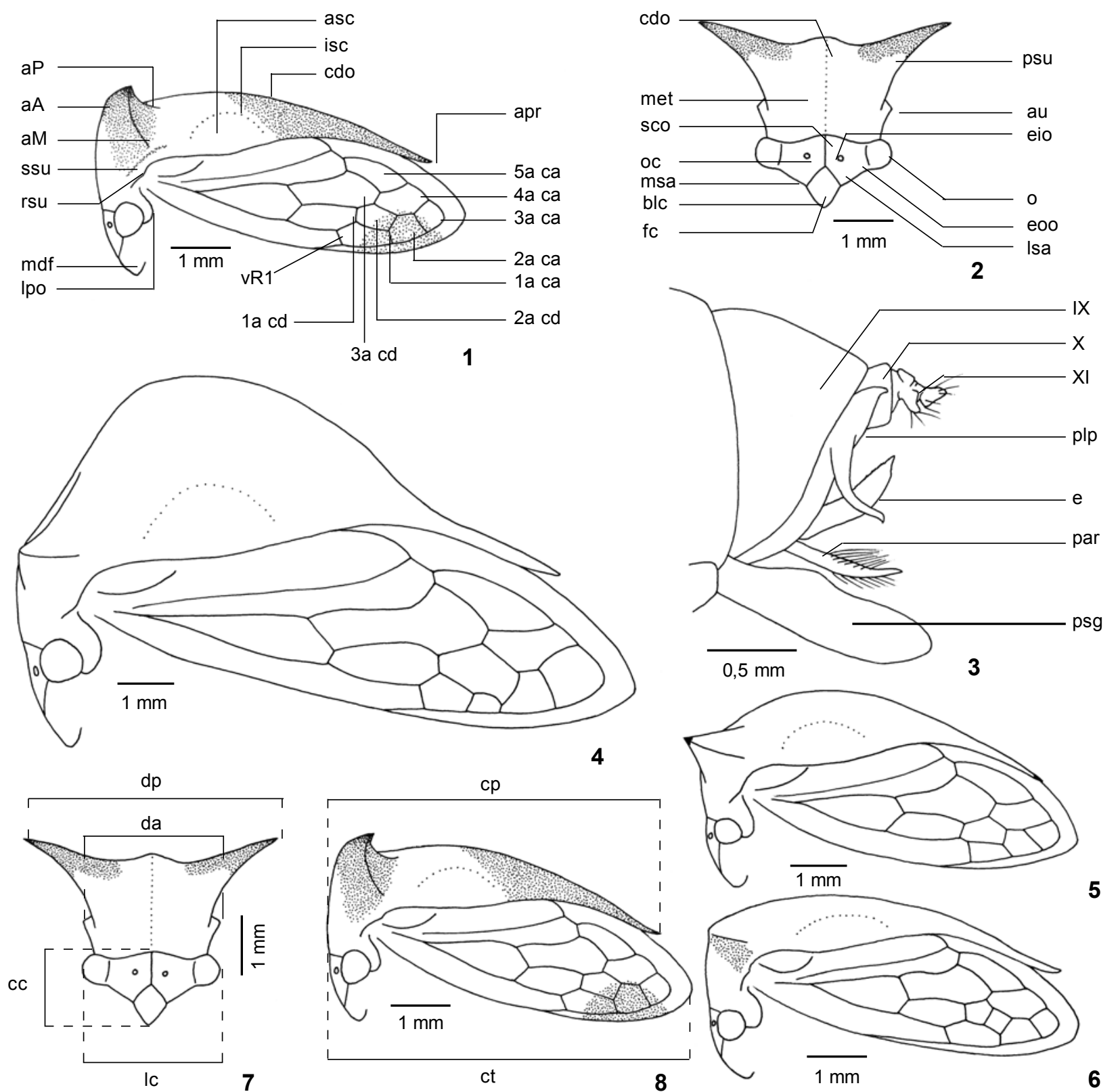

Figuras 1-8. (1-2) Aspectos da morfologia externa (Ceresa ustulata); (3) vista geral da genitália masculina (Ceresa paulistana); (4-6) aspectos da elevação, declive e constrição pré-apical do pronoto: (4) Ceresa mulsa, fortemente elevado, abruptamente em declive e com constrição pré-apical; (5) Ceresa spinifera, regularmente elevado, gradualmente em declive e sem constrição pré-apical; (6) Ceresa pauperata, fracamente elevado, levemente em declive e sem constrição pré-apical; (7-8) medidas (Ceresa ustulata). (aA) aresta anterior, (aM) aresta média, (aP) aresta posterior, (apr) ápice do pronoto, (asc) área semicircular, (au) ângulo umeral, (blc) bordo lateral da metade distal do frontoclípeo, (cc) comprimento da cabeça, (cdo) carena dorsal, (cp) comprimento do pronoto, (ct) comprimento total, (da) distância entre os ângulos umerais, (dp) distância entre os ápices dos processos supra-umerais, (e) edeago, (eio) espaço interocelar, (eoo) espaço ocelo-ocular, (fc) frontoclípeo, (isc) impressão semicircular, (IX, X e XI) $9^{\circ}, 10^{\circ}$ e $11^{\circ}$ urotergitos, (Ic) largura da cabeça, (Ipo) lóbulo pós-ocular, (Isa) lóbulo supra-antenal, (mdf) metade distal do frontoclípeo, (met) metopídio, (msa) margem do lóbulo supra-antenal, (par) parâmero esquerdo, (pig) pigóforo, (plp) placa lateral esquerda do pigóforo, (psg) placa subgenital, (o) olho, (oc) ocelo, (psu) processo supra-umeral, (rsu) região supra-umeral, (sco) sutura coronal, (ssu) sulco supra-umeral, (vR1) veia R1, (1a, 2a, 3a, 4a e 5a ca) células apicais, (1a, 2a e 3a cd) células discoidais. 
Pronoto tectiforme, com conformação e escultura variadas. Processos supra-umerais presentes, desenvolvidos ou rudimentares. Carena dorsal aparente em toda a sua extensão, arredondada ou cortante a partir do ponto mais elevado do pronoto. Ápice com extensão variável em relação à altura da base da $3^{a}$ célula apical das tégminas.

Tégminas e pernas com caracteres comuns aos demais gêneros de Ceresini.

Genitália. Macho. Edeago lanceolado em vista posterior, subcilíndrico ou achatado ântero-posteriormente; face dorsal com denticulação variada. Parâmeros bem desenvolvidos; metade distal, ápice e pilosidade com aspecto variado. Placas laterais do pigóforo alongadas, com um pequeno dente ou projeção apical; dente lateral usualmente bem desenvolvido, localizado geralmente no terço mediano, com direção e conformação variadas. Placa subgenital alongada e achatada, com formato variado; ápice fendido.

Comentários. Аmyot \& Serville (1843) descreveram o gênero Ceresa como "Prothorax à angles huméraux saillants en épine de chaque côté. Les autres caractères sont ceux des Smilies." Devido à sumariedade desta caracterização, existem mais de 100 nomes associados ao gênero, inclusive de espécies que se classificam em outras subfamílias de Membracidae.

A definição mais precisa do gênero Ceresa e sua diferenciação entre os gêneros próximos foi feita por CALDWELL (1949), com base principalmente nas estruturas da genitália masculina. Assim, muitas das espécies descritas pelos autores pioneiros como pertencentes ao gênero Ceresa foram transferidas para outros gêneros de Ceresini ou mesmo para outras tribos de Smiliinae ou subfamílias de Membracidae.

Na revisão apresentada por RemEs-Lenicov (1973), a caracterização do gênero permanece inalterada. Entretanto, o abundante material examinado e ilustrado pela autora veio reforçar a definição feita por CALDWELL (1949) para o gênero Ceresa e, com algumas ressalvas, confirmar sua distribuição como estritamente Neotropical.

A contribuição de Kopp \& Yonke (1979) segue também a caracterização apresentada por CALDWELL (1949), não somente para o gênero Ceresa, bem como para outros gêneros de Ceresini. Esse trabalho fortaleceu ainda mais a definição do gênero Ceresa e proporciona clara diferenciação dele entre os demais gêneros da tribo, com base principalmente nas estruturas da genitália masculina, além de estabelecer relações filogenéticas entre os gêneros com a utilização de metodologia cladística e anagenética.

Os gêneros de Ceresini que mais assemelham-se ao gênero Ceresa pelos caracteres externos e pela distribuição exclusiva ou ocorrência de algumas espécies na região Neotropical são Ilithucia Stål, 1867, Stictolobus Metcalf, 1916, Spissistilus Caldwell, 1949, Trichaetipyga Caldwell, 1949, Vestistilus Caldwell, 1949, Paraceresa Kopp \& Yonke, 1979 e Vestistiloides Andrade, 2003.

A diferenciação detalhada entre o gênero Ceresa e os su- pra-citados é alheia ao escopo do presente estudo. Boas caracterizações, ilustrações e diferenciações entre eles são encontradas na revisão da tribo Ceresini publicada por KopP \& YONKE (1979).

Embora o presente estudo siga a definição do gênero Ceresa com base nas estruturas da genitália masculina, foi dada ênfase na utilização de caracteres cromáticos e da morfologia externa, comuns à ambos os sexos, tanto na chave como nas descrições. Entretanto, é oportuno examinar, sempre que possível, as estruturas da genitália masculina, para dirimir dúvidas sobre a posição sistemática de espécies a identificar.

\section{Chave para identificação das espécies}

Tendo em vista a variabilidade de alguns caracteres ao nível de indivíduos, pode ser necessária a tentativa de utilização de dicotomias distintas da chave e a consulta às descrições, ilustrações e comentários apresentados para cada espécie, de forma a permitir a correta identificação do táxon a determinar.

As espécies são apresentadas na ordem em que aparecem na chave, salvo aquelas que, por apresentarem variação extrema de algum caráter utilizado, tiveram que ter duas entradas na mesma. Nestes casos, elas são apresentadas na ordem em que aparecem na chave, segundo o estado predominante do caráter variável.

1. Tégminas com a veia R1 originando-se na $1^{\mathrm{a}}$ célula discoidal 2

$1^{\prime}$. Tégminas com a veia $\mathrm{R} 1$ originando-se na $2^{\mathrm{a}}$ célula discoidal 26

2. Processos supra-umerais rudimentares ............................. 3

2 '. Processos supra-umerais desenvolvidos ............................. 4

3. Cabeça com a superfície lisa no espaço interocelar, corrugada nas demais regiões; pronoto com pontuação heterogênea; espaço entre os processos supra-umerais em forma de cumeeira .................................................... C. abbreviata

3'. Cabeça com a superfície fortemente estriada, corrugada no frontoclípeo e nos lóbulos supra-antenais; pronoto com pontuação homogênea; espaço entre os processos supraumerais convexo . C. nigripectus

4. Pronoto fortemente elevado atrás do espaço entre os processos supra-umerais e abruptamente em declive e afilado para o ápice após o ponto mais elevado .............. 5

4 '. Pronoto não fortemente elevado atrás do espaço entre os processos supra-umerais e nem abruptamente em declive e afilado para o ápice após o ponto mais elevado .............. 6

5. Pronoto com pontuação homogênea, não abaulado nas regiões adjacentes às impressões semicirculares; processos supra-umerais prismáticos na metade distal; áreas semicirculares planas ................................................ C. mulsa

5'. Pronoto com pontuação heterogênea, abaulado nas regiões adjacentes às impressões semicirculares; processos supraumerais cônicos na metade distal; áreas semicirculares convexas C. amazonica 
6. Processos supra-umerais cônicos na metade distal 7

6'. Processos supra-umerais prismáticos na metade distal .. 12

7. Pronoto fracamente elevado atrás do espaço entre os processos supra-umerais e levemente em declive e afilado para o ápice após o ponto mais elevado ... 8

7 '. Pronoto regularmente elevado atrás do espaço entre os processos supra-umerais e gradualmente em declive e afilado para o ápice após o ponto mais elevado 9

8. Pronoto com faixas longitudinais de coloração alternada, tégminas com o limbo escurecido; cabeça com a superfície fracamente estriada, lisa no frontoclípeo e nos lóbulos supra-antenais; pronoto com pontuação heterogênea; carena dorsal cortante a partir do ponto mais elevado do pronoto; ápice do pronoto não atingindo a altura da base da $3^{\text {a }}$ célula apical das tégminas ................. C. uruguayensis

8'. Pronoto sem faixas longitudinais de coloração alternada, tégminas com o limbo hialino; cabeça com a superfície fortemente estriada, com algumas pontuações, corrugada no frontoclípeo e nos lóbulos supra-antenais; pronoto com pontuação homogênea; carena dorsal arredondada a partir do ponto mais elevado do pronoto, cortante apenas em sua porção distal; ápice do pronoto ultrapassando a altura da base da $3^{\mathrm{a}}$ célula apical das tégminas ........ C. pauperata

9. Cabeça com a superfície estriada na base e nos espaços ocelooculares, lisa nas demais regiões .. 10

9'. Cabeça com a superfície fortemente estriada, corrugada no frontoclípeo e nos lóbulos supra-antenais 11

10. Sutura coronal não atingindo a base do frontoclípeo; pronoto abaulado nas regiões adjacentes às impressões semicirculares e constricto ao nível do ângulo interno das tégminas; lóbulos pós-oculares sulcados ao nível do ângulo externo dos olhos; metade distal da face posterior dos processos supra-umerais lisa C. axillaris

10 '. Sutura coronal atingindo a base do frontoclípeo; pronoto não abaulado nas regiões adjacentes às impressões semicirculares e nem constricto ao nível do ângulo interno das tégminas; lóbulos pós-oculares sem modificações ao nível do ângulo externo dos olhos; metade distal da face posterior dos processos supra-umerais corrugada C. stylata

11. Coloração geral ferruginosa, tégminas ambarinas; espaço interocelar convexo; espaços ocelo-oculares deprimidos; lóbulos supra-antenais escavados; metade distal do frontoclípeo com os bordos laterais chanfrados; pronoto constricto ao nível do ângulo interno das tégminas; lóbulos pós-oculares sulcados ao nível do ângulo externo dos olhos; metade distal da face posterior dos processos supra-umerais lisa .. C. distans

11'. Coloração geral amarelada, tégminas hialinas; espaço interocelar plano; espaços ocelo-oculares planos; lóbulos supra-antenais planos; metade distal do frontoclípeo com os bordos laterais inteiros; pronoto não constricto ao nível do ângulo interno das tégminas; lóbulos pós-oculares sem modificações ao nível do ângulo externo dos olhos; metade distal da face posterior dos processos supra-umerais corrugada ..................................................... . . nigripectus

12. Face dorsal dos processos supra-umerais plana ou escavada 13

12 '. Face dorsal dos processos supra-umerais arredondada...17

13. Pronoto fracamente elevado atrás do espaço entre os processos supra-umerais e levemente em declive e afilado para o ápice após o ponto mais elevado.....

14

13'. Pronoto regularmente elevado atrás do espaço entre os processos supra-umerais e gradualmente em declive e afilado para o ápice após o ponto mais elevado 16

14. Processos supra-umerais e região posterior do pronoto com coloração distintamente amarronzada; espaço interocelar plano; lóbulos supra-antenais planos; sulcos supra-umerais bem marcados C. ustulata

$14^{\prime}$.Processos supra-umerais e região posterior do pronoto sem coloração distintamente amarronzada; espaço interocelar convexo; lóbulos supra-antenais escavados; sulcos supraumerais pouco marcados

15

15. Coloração geral ferruginosa, mais escurecida no fundo das pontuações; margem costal das tégminas maculada ao nível das $1^{\text {a }}$ e $2^{\text {a }}$ células apicais; espaços ocelo-oculares deprimidos; metade distal do frontoclípeo distintamente dirigida para trás; processos supra-umerais retos na metade distal; áreas semicirculares bem impressas ................... C. projecta

15'. Coloração geral amarelada, não escurecida no fundo das pontuações; margem costal das tégminas não maculada ao nível das $1^{\text {a }}$ e $2^{\text {a }}$ células apicais; espaços ocelo-oculares planos; metade distal do frontoclípeo distintamente dirigida para baixo; processos supra-umerais curvos na metade distal; áreas semicirculares não impressas ....... C. platycera

16. Coloração geral amarelada, sem máculas claras, não escurecida na face ventral dos processos supra-umerais e região posterior do pronoto; face ventral da cabeça, pleuras, coxas e fêmures amarelados; cabeça com a superfície estriada na base e nos espaços ocelo-oculares, lisa no espaço interocelar e corrugada nas demais regiões; sulcos supra-umerais pouco marcados; metade distal da face posterior dos processos supra-umerais pontuada; aresta $\mathrm{M}$ intumescida em suas metades distal e basal; áreas semicirculares não impressas

C. piramidalis

16'. Coloração geral amarronzada, com máculas claras, mais escurecida na face ventral dos processos supra-umerais e região posterior do pronoto; face ventral da cabeça, pleuras, coxas e fêmures enegrecidos; cabeça com a superfície estriada, com algumas pontuações, corrugada no frontoclípeo e nos lóbulos supra-antenais; sulcos supra-umerais bem marcados; metade distal da face posterior dos processos supra-umerais corrugada; aresta $\mathrm{M}$ cortante em sua metade distal, intumescida em sua metade basal; áreas semicirculares bem impressas C. atrata

Revista Brasileira de Zoologia 21 (4): 671-738, dezembro 2004 
17. Pronoto com faixas longitudinais de coloração alternada; porção apical das faces ventral e posterior dos processos supra-umerais enegrecida 18

17'. Pronoto sem faixas longitudinais de coloração alternada; porção apical das faces ventral e posterior dos processos supra-umerais acastanhada

18. Cabeça sem calosidade distinta junto à margem superior na direção dos ocelos; pronoto regularmente elevado atrás do espaço entre os processos supra-umerais e gradualmente em declive e afilado para o ápice após o ponto mais elevado; sulcos supra-umerais bem marcados; processos supraumerais dirigidos para frente e para os lados; carena dorsal cortante a partir do ponto mais elevado do pronoto; ápice do pronoto ultrapassando a altura da base da $3^{\text {a célula apical }}$ das tégminas C. cavicornis

18'. Cabeça com calosidade distinta junto à margem superior na direção dos ocelos; pronoto fracamente elevado atrás do espaço entre os processos supra-umerais e levemente em declive e afilado para o ápice após o ponto mais elevado; sulcos supra-umerais pouco marcados; processos supra-umerais dirigidos para frente; carena dorsal arredondada a partir do ponto mais elevado do pronoto, cortante apenas em sua porção distal; ápice do pronoto não ultrapassando a altura da base da $3^{\text {a }}$ célula apical das tégminas C. prosocera

19. Espaço entre os processos supra-umerais convexo........ 20

$19^{\prime}$.Espaço entre os processos supra-umerais plano ou côncavo

20. Cabeça com a superfície fracamente estriada, lisa no frontoclípeo e nos lóbulos supra-antenais; lóbulos supraantenais com as margens arredondadas; pronoto com pontuação heterogênea; aresta $\mathrm{M}$ mais pronunciada em sua metade distal C. brunnicornis

$20^{\prime}$. Cabeça com a superfície fortemente estriada, corrugada no frontoclípeo e nos lóbulos supra-antenais; lóbulos supraantenais com as margens sinuosas; pronoto com pontuação homogênea; aresta $M$ mais pronunciada em sua metade basal....

21. Coloração geral acastanhada, tégminas ambarinas; espaço interocelar convexo; lóbulos supra-antenais escavados; metade distal do frontoclípeo com os bordos laterais chanfrados; pronoto constricto ao nível do ângulo interno das tégminas; lóbulos pós-oculares sulcados ao nível do ângulo externo dos olhos; áreas semicirculares bem impressas C. cuprea

21'. Coloração geral amarelada, tégminas hialinas; espaço interocelar plano; lóbulos supra-antenais planos; metade distal do frontoclípeo com os bordos laterais inteiros; pronoto não constricto ao nível do ângulo interno das tégminas; lóbulos pós-oculares sem modificações ao nível do ângulo externo dos olhos; áreas semicirculares não impressas C. nigripectus

22. Processo pronotal posterior com coloração distintamente amarronzada, tégminas com escurecimento em todas as células apicais e no limbo; aresta $\mathrm{M}$ com nítido intumescimento em sua metade basal ..................... C. maculipennis

22 '. Processo pronotal posterior sem coloração distintamente amarronzada, tégminas sem escurecimento em todas as células apicais e no limbo; aresta $\mathrm{M}$ sem nítido intumescimento em sua metade basal ........................................ 23

23. Cabeça com calosidades proeminentes nos espaços ocelooculares 24

23 '. Cabeça sem calosidades proeminentes nos espaços ocelooculares 25

24(23). Região posterior do pronoto com uma banda transversal amarronzada; frontoclípeo piriforme, metade distal com os bordos laterais inteiros; pronoto abaulado nas regiões adjacentes às impressões semicirculares e constricto ao nível do ângulo interno das tégminas; aresta $\mathrm{M}$ pronunciada em sua metade distal e intumescida em sua metade basal ..... C. paulistana

24 '. Região posterior do pronoto sem uma banda transversal amarronzada; frontoclípeo sublosângico, metade distal com os bordos laterais chanfrados; pronoto não abaulado nas regiões adjacentes às impressões semicirculares e nem constricto ao nível do ângulo interno das tégminas; aresta $\mathrm{M}$ intumescida em suas metades distal e basal .C. paranaensis

25. Coloração geral amarelo-esverdeada, não escurecida no fundo das pontuações e sem um anel pré-apical mais claro no processo pronotal posterior, tégminas hialinas; espaços ocelo-oculares planos; lóbulos supra-antenais planos; pronoto não abaulado nas regiões adjacentes às impressões semicirculares; lóbulos pós-oculares com a superfície pontuada, sulcados ao nível do ângulo externo dos olhos .....

C. malina

25'. Coloração geral amarelo-ferruginosa, mais escurecida no fundo das pontuações e com um anel pré-apical mais claro no processo pronotal posterior, tégminas ambarinas; espaços ocelo-oculares deprimidos; lóbulos supra-antenais escavados; pronoto abaulado nas regiões adjacentes às impressões semicirculares; lóbulos pós-oculares com a superfície corrugada, sem modificações ao nível do ângulo externo dos olhos ....................................... C. plaumanni

26. Cabeça com calosidade distinta junto à margem superior na direção dos ocelos; pronoto fortemente elevado atrás do espaço entre os processos supra-umerais e abruptamente em declive e afilado para o ápice após o ponto mais elevado C. denticulata

$26^{\prime}$. Cabeça sem calosidade distinta junto à margem superior na direção dos ocelos; pronoto não fortemente elevado atrás do espaço entre os processos supra-umerais e nem abruptamente em declive e afilado para o ápice após o ponto mais

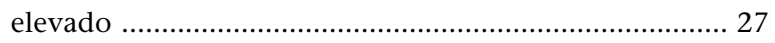

27. Processos supra-umerais cônicos na metade distal ....... 28

27'. Processos supra-umerais prismáticos na metade distal... 31

Revista Brasileira de Zoologia 21 (4): 671-738, dezembro 2004 
28. Pronoto com pontuação homogênea; espaço entre os processos supra-umerais convexo 29

28 '. Pronoto com pontuação heterogênea; espaço entre os processos supra-umerais plano ou côncavo .................. 30

29. Coloração geral amarelada, sem máculas claras, tégminas com as veias amareladas e não escurecidas no terço distal; cabeça com a superfície fracamente estriada na base e nos espaços ocelo-oculares, lisa nas demais regiões; sutura coronal não atingindo a base do frontoclípeo; espaços ocelooculares planos; regiões supra-umerais com a superfície pontuada; áreas semicirculares bem impressas .... C. vitulus

29'. Coloração geral ferruginosa, com máculas claras, tégminas com as veias acastanhadas e mais escurecidas no terço distal; cabeça com a superfície fracamente estriada, corrugada no frontoclípeo e nos lóbulos supra-antenais; sutura coronal atingindo a base do frontoclípeo; espaços ocelos-oculares deprimidos; regiões supra-umerais com a superfície lisa; áreas semicirculares não impressas C. albosignata

30. Coloração geral amarelo-pálida, sem máculas claras, acastanhada na metade distal dos processos supra-umerais e na região posterior do pronoto; cabeça com a superfície fracamente estriada na base e nos espaços ocelo-oculares, lisa nas demais regiões; espaços ocelo-oculares deprimidos; lóbulos supra-antenais com as margens arredondadas; pronoto não constricto ao nível do ângulo interno das tégminas; regiões supra-umerais com a superfície pontuada; processos supra-umerais dirigidos para frente e para os lados, inclinados para cima e com a metade distal da face posterior pontuada, espaço entre eles côncavo; espaço anterior a aresta $\mathrm{M}$ intumescido C. spinifera

30'. Coloração geral amarelo-escura, com máculas claras, não acastanhada na metade distal dos processos supra-umerais e na região posterior do pronoto; cabeça com a superfície lisa; espaços ocelo-oculares planos; lóbulos supra-antenais com as margens sinuosas; pronoto constricto ao nível do ângulo interno das tégminas; regiões supra-umerais com a superfície lisa; processos supra-umerais dirigidos para os lados e para trás, inclinados para baixo e com a metade distal da face posterior lisa, espaço entre eles plano; espaço anterior a aresta $\mathrm{M}$ normal C. viridilineata

31. Face dorsal dos processos supra-umerais plana ou escavada

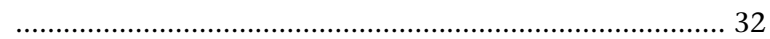

$31^{\prime}$. Face dorsal dos processos supra-umerais arredondada....33

32. Região posterior do pronoto com duas bandas transversais amarronzadas, espaço entre os processos supra-umerais amarelado, margem costal das tégminas maculada ao nível

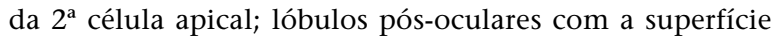
corrugada, calosos ao nível do ângulo externo dos olhos; face dorsal dos processos supra-umerais plana.

C. fasciatithorax

32 '. Região posterior do pronoto com uma banda transversal amarronzada, espaço entre os processos supra-umerais amarronzado, margem costal das tégminas não maculada ao nível da $2^{\text {a }}$ célula apical; lóbulos pós-oculares com a superfície pontuada, sem modificações ao nível do ângulo externo dos olhos; face dorsal dos processos supra-umerais escavada C. similis

33. Pronoto sem faixas longitudinais de coloração alternada; porção apical das faces ventral e posterior dos processos supra-umerais amarelada. 34

$33^{\prime}$. Pronoto com faixas longitudinais de coloração alternada; porção apical das faces ventral e posterior dos processos supra-umerais enegrecida ............................................. 35

34. Tégminas mais escurecidas no terço distal, margem costal não maculada ao nível da $2^{\mathrm{a}}$ célula apical; cabeça com a superfície fracamente estriada na base e nos espaços ocelooculares, lisa nas demais regiões; espaço interocelar convexo; lóbulos supra-antenais escavados; frontoclípeo piriforme; pronoto com pontuação heterogênea, abaulado nas regiões adjacentes às impressões semicirculares e constricto ao nível do ângulo interno das tégminas; lóbulos pósoculares sem modificações ao nível do ângulo externo dos olhos; sulcos supra-umerais bem marcados, regiões supraumerais com a superfície lisa; processos supra-umerais dirigidos para os lados e para trás, espaço entre eles plano; impressões semicirculares bem distintas, áreas semicirculares convexas; carena dorsal cortante a partir do ponto mais elevado do pronoto C. rufescens

$34^{\prime}$. Tégminas não escurecidas no terço distal, margem costal maculada ao nível da $2^{\text {a }}$ célula apical; cabeça com a superfície corrugada; espaço interocelar plano; lóbulos supra-antenais planos; frontoclípeo sublosângico; pronoto com pontuação homogênea, não abaulado nas regiões adjacentes às impressões semicirculares e não constricto ao nível do ângulo interno das tégminas; lóbulos pós-oculares sulcados, calosos e angulosos ao nível do ângulo externo dos olhos; sulcos supra-umerais pouco marcados, regiões supraumerais com a superfície pontuada; processos supra-umerais dirigidos para frente e para os lados, espaço entre eles côncavo; impressões semicirculares pouco distintas, áreas semicirculares planas; carena dorsal arredondada a partir do ponto mais elevado do pronoto .......................... C. calosa

35. Cabeça com a superfície fortemente esculturada; espaços ocelo-oculares deprimidos; frontoclípeo sublosângico, metade distal com os bordos laterais chanfrados; pronoto abaulado nas regiões adjacentes às impressões semicirculares; processos supra-umerais retos na metade distal, dirigidos para frente e para os lados e com os ápices voltados para os lados; arestas A e P aparentes em suas metades distais; ápice do pronoto ultrapassando a altura da base da $3^{\text {a }}$ célula apical das tégminas ......................... C. cavicornis

35'. Cabeça com a superfície fracamente esculturada; espaços ocelo-oculares planos; frontoclípeo piriforme, metade distal com os bordos laterais inteiros; pronoto não abaulado nas

Revista Brasileira de Zoologia 21 (4): 671-738, dezembro 2004 
regiões adjacentes às impressões semicirculares; processos supra-umerais curvos na metade distal, dirigidos para os lados e com os ápices voltados para os lados e para trás; arestas A e P cortantes em suas metades distais; ápice do pronoto não ultrapassando a altura da base da $3^{\text {a }}$ célula apical das tégminas. 36

36. Tégminas sem escurecimento em todas as células apicais e no limbo, margem costal maculada ao nível da $2^{\text {a célula }}$ apical; cabeça com a superfície estriada, com algumas pontuações, corrugada no frontoclípeo e nos lóbulos supraantenais; lóbulos supra-antenais planos; pronoto fracamente elevado atrás do espaço entre os processos supra-umerais, levemente em declive e afilado para o ápice após o ponto mais elevado e não constricto ao nível do ângulo interno das tégminas; lóbulos pós-oculares sulcados e calosos ao nível do ângulo externo dos olhos; processos supra-umerais inclinados para cima, espaço entre eles convexo; carena dorsal arredondada a partir do ponto mais elevado do pronoto, cortante apenas em sua porção distal

C. chacoana

36'. Tégminas com escurecimento em todas as células apicais e no limbo, margem costal não maculada ao nível da $2^{\mathrm{a}}$ célula apical; cabeça com a superfície estriada na base e nos espaços ocelo-oculares, lisa nas demais regiões; lóbulos supra-antenais escavados; pronoto regularmente elevado atrás do espaço entre os processos supra-umerais, gradualmente em declive e afilado para o ápice após o ponto mais elevado e constricto ao nível do ângulo interno das tégminas; lóbulos pósoculares sem modificações ao nível do ângulo externo dos olhos; processos supra-umerais inclinados para baixo, espaço entre eles plano; carena dorsal cortante a partir do ponto mais elevado do pronoto C. remeslenicovae

\section{Ceresa abbreviata Andrade, 1989 Figs 9-15}

Ceresa abbreviata Andrade, 1989: 140, figs 1 e 2, 5 a 8; McKamey, 1998: 244 (cat.).

Medidas. Macho (holótipo)/fêmea (parátipo). Largura da cabeça: 2,68/2,64; comprimento da cabeça: 1,34/1,32; distância entre os ângulos umerais: 2,96/2,84; distância entre os ápices dos processos supra-umerais: $3,04 / 3,04$; comprimento do pronoto: 6,17/5,83; comprimento total: 7,17/6,75.

Descrição. Macho. Coloração geral amarelada, com máculas esbranquiçadas, mais escura no metopídio. Lóbulos pósoculares e flancos do pronoto, acima dos ângulos umerais, acastanhados; ápice do pronoto negro. Tégminas hialinas, veias amareladas. Face ventral da cabeça e pleuras torácicas enegrecidas; esternos abdominais negros. Pernas ferruginosas, com as coxas maculadas de negro.

Cabeça com a superfície lisa no espaço interocelar, corrugada nas demais regiões. Sutura coronal não atingindo a base do frontoclípeo. Espaço interocelar convexo, espaços ocelo-oculares planos. Lóbulos supra-antenais planos, com as margens arredondadas. Frontoclípeo sublosângico, metade distal com os bordos laterais chanfrados e dirigido para trás.

Pronoto com pontuação heterogênea, não abaulado nas regiões adjacentes às impressões semicirculares, com elevação máxima entre os processos supra-umerais, gradualmente em declive e afilado para o ápice após o ponto mais elevado e não constricto ao nível do ângulo interno das tégminas. Metopídio pentagonal, com as impressões musculares em forma de L invertido. Lóbulos pós-oculares com a superfície corrugada, calosos ao nível do ângulo externo dos olhos. Sulcos supraumerais bem marcados, regiões supra-umerais com a superfície lisa. Processos supra-umerais rudimentares; espaço entre eles em forma de cumeeira. Impressões semicirculares pouco distintas, áreas semicirculares planas e não impressas. Carena dorsal cortante a partir do ponto mais elevado do pronoto. Ápice atingindo a altura da base da $3^{\mathrm{a}}$ célula apical das tégminas.

Tégminas com a veia $\mathrm{R} 1$ originando-se na $1^{\mathrm{a}}$ célula discoidal.

Genitália. Edeago subcilíndrico, afilado para o ápice; face dorsal com uma fileira de dentículos de cada lado, divergentes entre si, delimitando denticulação em mosaico na metade superior. Parâmeros achatados lateralmente na metade distal, curvados para cima e para dentro no terço distal; ápice em forma de gancho, mais esclerotinizado, curvado para baixo; pilosidade longa e homogênea distribuída ao longo dos bordos dorsal e ventral do terço distal, mais extensa no bordo ventral. Placas laterais do pigóforo com o dente apical bulbiforme, situado no ângulo posterior; dente lateral bem desenvolvido, localizado no terço superior, curvado para cima e com o ápice arredondado. Placa subgenital duas vezes mais longa que larga basalmente, estreitando-se após a região mediana.

Fêmea. Semelhante ao macho, apenas um pouco menor.

Material examinado. BrasiL, Minas Gerais: Poços de Caldas, morro do Ferro, 19.IX.1982 (B.C. Lopes), 1 fêmea (BCL; parátipo); Paraná: Curitiba, 30.IV.1961 (S. Laroca), 1 macho (DZUP; holótipo).

Distribuição geográfica. Brasil: Minas Gerais e Paraná (ANDRADE 1989).

Localidade-tipo. Brasil. Paraná: Curitiba.

Notas sobre os tipos. O holótipo macho está depositado na DZUP, em bom estado de conservação, alfinetado e com o abdome dissecado. O exemplar apresenta uma célula extranumerária em ambas as tégminas, entre as $2^{\mathrm{a}}$ e $3^{\mathrm{a}}$ células discoidais. Existe um parátipo fêmea depositado na coleção BCL.

Planta hospedeira. Desconhecida.

Comentários. Difere das demais espécies notadamente pela quase ausência de processos supra-umerais, o que resulta num pronoto pentagonal, em vista anterior, e com o aspecto geral de uma cunha, em vista dorsal. 


\section{Ceresa mulsa Remes-Lenicov, 1973 Figs 16-22}

Ceresa mulsa Remes-Lenicov, 1973: 65, lám. II, figs 10 a 13; McKamey, 1998: 245 (cat.).

Medidas. Macho/fêmea (holótipo). Largura da cabeça: 3,36/3,68; comprimento da cabeça: 1,68/1,84; distância entre os ângulos umerais: $3,36 / 3,84$; distância entre os ápices dos processos supra-umerais: 5,75/6,00; comprimento do pronoto: 8,83/9,52; comprimento total: 10,00/10,50.

Descrição. Macho. Coloração geral acastanhada, com máculas amareladas. Aresta $\mathrm{M}$ amarelada; carena dorsal escurecida a partir do ponto mais elevado do pronoto; ápices dos processos supra-umerais e do pronoto negros. Tégminas e veias ambarinas. Região ventral do corpo e pernas acastanhadas.

Cabeça com a superfície fracamente estriada, lisa no frontoclípeo e nos lóbulos supra-antenais. Sutura coronal atingindo a base do frontoclípeo, mais marcada junto a margem superior. Espaço interocelar convexo, espaços ocelo-oculares deprimidos. Lóbulos supra-antenais escavados, com as margens sinuosas. Frontoclípeo sublosângico, metade distal com os bordos laterais chanfrados e dirigida para baixo.

Pronoto com pontuação homogênea, não abaulado nas regiões adjacentes às impressões semicirculares, fortemente elevado atrás do espaço entre os processos supra-umerais, abruptamente em declive e afilado para o ápice após o ponto mais elevado e constricto ao nível do ângulo interno das tégminas. Metopídio trapezoidal, com as impressões musculares em forma de $\mathrm{V}$ invertido. Lóbulos pós-oculares com a superfície corrugada, sulcados e calosos ao nível do ângulo externo dos olhos. Sulcos supra-umerais bem marcados, regiões supraumerais com a superfície pontuada. Processos supra-umerais desenvolvidos, prismáticos, retos na metade distal, dirigidos para os lados, sem inclinação e com os ápices voltados para os lados; face dorsal arredondada, face posterior pontuada; espaço entre eles plano; arestas A e P aparentes na metade distal; aresta $\mathrm{M}$ pronunciada em toda a sua extensão; espaços anterior e posterior a aresta $\mathrm{M}$ escavados. Impressões semicirculares pouco distintas, áreas semicirculares planas e não impressas. Carena dorsal cortante a partir do ponto mais elevado do pronoto. Ápice ultrapassando a altura da base da $3^{\mathrm{a}}$ célula apical das tégminas.

Tégminas com a veia $\mathrm{R} 1$ originando-se na $1^{\mathrm{a}}$ célula discoidal.

Genitália. Edeago plano-convexo, achatado ântero-posteriormente, notadamente na porção apical; face dorsal um pouco escavada, com uma fileira de dentículos bem desenvolvidos ao longo dos bordos da escavação, paralelas entre si e delimitando denticulação em mosaico próximo ao ápice. Parâmeros achatados lateralmente e abruptamente constrictos no bordo inferior, ao nível do quinto apical; ápice em forma de gancho, mais esclerotinizado, curvado para baixo e um pouco para den- tro; pilosidade longa e heterogênea, distribuída ao longo do quinto distal do bordo superior e do quarto distal do bordo inferior. Placas laterais do pigóforo com o dente apical bulbiforme, situado no ângulo posterior; dente lateral bem desenvolvido, localizado no terço mediano, diagonalmente dirigido para baixo, com o ápice arredondado e com um dentículo curvado também para baixo. Placa subgenital subretangular, mais de duas vezes longa que larga medianamente.

Fêmea. Semelhante ao macho, apenas um pouco maior. Material examinado. EQUADOR, Napo: Sacha, 5.III.1983 (L. Huggert), 1 fêmea (LU); 5 km S Sacha, "cultiv. forest", 7.III.1983 (L. Huggert), 1 fêmea (LU). Peru, Huánuco: rio Huallaga, Tingo Maria, 700 m, X.1946 (Weyrauch), 1 fêmea (FML; holótipo); rio Huallaga, Tingo Maria, 700 m, X.1946 (Weyrauch), 1 fêmea (UPR); Tingo Maria, 700 m, VII.1974 (Bordón), 2 fêmeas (CB); Pasco: Pichanaz, 63 km SO de Pto. Bermúdez, 12.IX.1987 (P. Lozada), 1 fêmea (MHNJP); Iscozacín, 250 m, 12.VIII.1987 (P. Lozada), 1 macho (MHNJP); San Juan de Cacazú, 830 m, 1718.IX.1987 (P. Lozada), 1 fêmea (MHNJP); Junín: Perené, El Campamiento, VI.1920 (Cornell Univ. Exp.), 1 fêmea (CU; identificado como C. patruelis (sic) Stål, W.D. Funkhouser det.). Bolívia, La Paz: Coroico, sem data (sem coletor), 1 fêmea (MZUSP); Chuquisaca: El Palmar, sem data (sem coletor), 1 fêmea (DZUP). Sem indicação de localidade, sem data (O. Garlepp), 1 fêmea (MZUSP).

Distribuição geográfica. EUQADOR: Napo. PERU: Huánuco e Junín (Remes-Lenicov 1973) e Pasco. Bolívia: La Paz e Chuquisaca. Localidade-tipo. Peru, Huánuco: rio Huallaga, Tingo Maria, $700 \mathrm{~m}$.

Notas sobre os tipos. O holótipo fêmea está depositado na FML, em razoável estado de conservação, alfinetado e com o abdome dissecado. O exemplar apresenta uma célula extranumerária na tégmina esquerda, entre a $1^{\mathrm{a}}$ e $2^{\mathrm{a}}$ células apicais, uma perfuração no pronoto acima da impressão muscular esquerda do metopídio, faltam o flagelo antenal direito, fêmur, tíbia e tarso I esquerdos, tíbia e tarso III esquerdos, fêmur, tíbia e tarso I direitos e tíbia e tarso II direitos. Segundo a descrição original, existe um parátipo fêmea depositado também na FML e dois parátipos fêmeas na DZUP.

Planta hospedeira. Desconhecida.

Comentários. Esta espécie foi descrita com base somente em exemplares fêmeas. O exame de um exemplar macho, comparado com o holótipo, e a análise das estruturas de sua genitália, mostrou que se trata de uma espécie realmente classificável no gênero Ceresa. Não obstante, discorda-se da identificação proposta para ao menos um dos exemplares incluídos no Material estudado da descrição original. Segundo Andrade (2002), ele corresponde a C. amazonica Andrade.

Foram observadas variações no aspecto da face dorsal dos processos supra-umerais e do espaço entre eles.

Difere das demais espécies notadamente pela forte elevação do pronoto atrás do espaço entre os processos supraumerais.

Revista Brasileira de Zoologia 21 (4): 671-738, dezembro 2004 

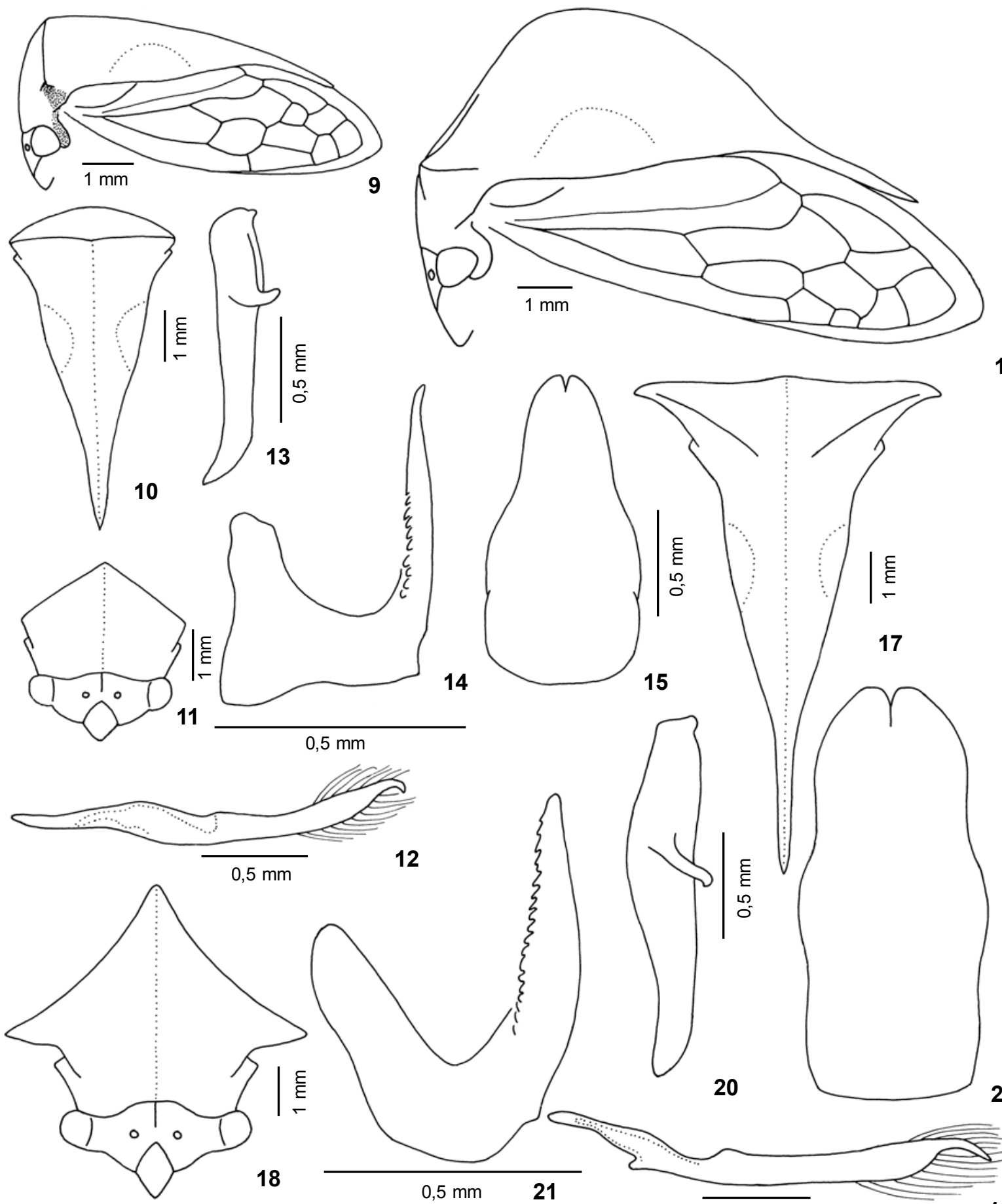

12
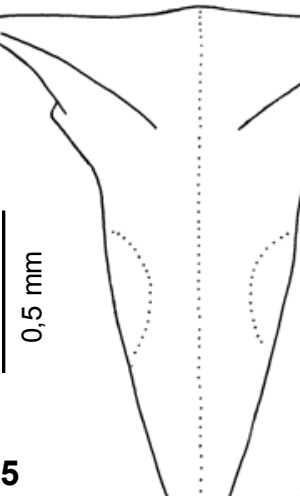

16
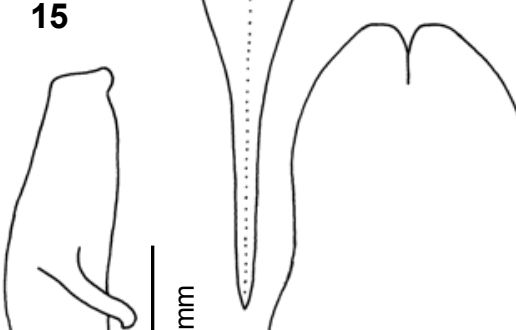

20

22

18
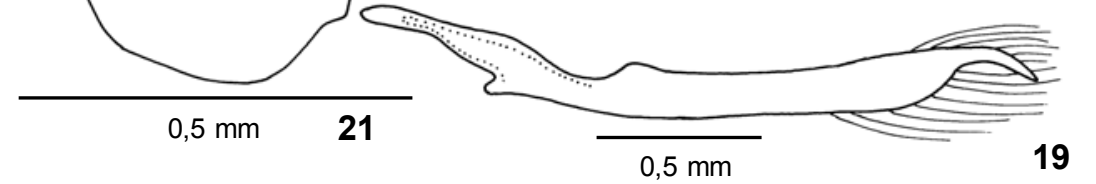

Figuras 9-22. (9-15) Ceresa abbreviata: (9) cabeça, pronoto e tégmina, vista lateral; (10) pronoto, vista dorsal; (11) cabeça e pronoto, vista frontal; (12) parâmero esquerdo, vista lateral; (13) placa lateral esquerda do pigóforo, vista lateral; (14) edeago, vista lateral; (15) placa subgenital, vista ventral; (16-22) Ceresa mulsa: (16) cabeça, pronoto e tégmina, vista lateral; (17) pronoto, vista dorsal; (18) cabeça e pronoto, vista frontal; (19) parâmero esquerdo, vista lateral; (20) placa lateral esquerda do pigóforo, vista lateral; (21) edeago, vista lateral; (22) placa subgenital, vista ventral.

Revista Brasileira de Zoologia 21 (4): 671-738, dezembro 2004 


\section{Ceresa amazonica Andrade, 2002 Figs 23-29}

Ceresa amazonica Andrade, 2002: 40, figs 1 e 2, 9 a 12.

Medidas. Macho (parátipo)/fêmea (holótipo). Largura da cabeça: 2,80/3,20; comprimento da cabeça: 1,40/1,60; distância entre os ângulos umerais: 2,72/3,08; distância entre os ápices dos processos supra-umerais: 4,24/5,33; comprimento do pronoto: 7,33/8,33; comprimento total: 8,17/9,33.

Descrição. Macho. Coloração geral acastanhada. Duas faixas muito tênues que partem da face posterior dos processos supra-umerais e contornam as áreas semicirculares e uma mancha pré-apical no processo pronotal posterior, amareladas; ápices dos processos supra-umerais e do pronoto negros. Tégminas e veias ambarinas. Região ventral do corpo e pernas ferruginosas.

Cabeça com a superfície lisa. Sutura coronal não atingindo a base do frontoclípeo. Espaço interocelar convexo, espaços ocelo-oculares deprimidos. Lóbulos supra-antenais escavados, com as margens sinuosas. Frontoclípeo sublosângico, metade distal com os bordos laterais chanfrados e dirigida para baixo.

Pronoto com pontuação heterogênea, abaulado nas regiões adjacentes às impressões semicirculares, fortemente elevado atrás do espaço entre os processos supra-umerais, abruptamente em declive e afilado para o ápice após o ponto mais elevado e constricto ao nível do ângulo interno das tégminas. Metopídio trapezoidal, com as impressões musculares em forma de $\mathrm{V}$ invertido. Lóbulos pós-oculares com a superfície lisa, sulcados e calosos ao nível do ângulo externo dos olhos. Sulcos supra-umerais bem marcados, regiões supra-umerais com a superfície lisa. Processos supra-umerais desenvolvidos, prismáticos na metade basal e cônicos na metade distal, curvos na metade distal, dirigidos para os lados, sem inclinação e com os ápices voltados para os lados e para trás; face dorsal arredondada, face posterior pontuada na metade basal e lisa na metade distal; espaço entre eles plano; arestas A e P ausentes na metade distal; aresta $\mathrm{M}$ pronunciada como um intumescimento somente na metade basal; espaço anterior a aresta $\mathrm{M}$ normal, espaço posterior a aresta $\mathrm{M}$ escavado. Impressões semicirculares bem distintas, áreas semicirculares convexas e não impressas. Carena dorsal cortante a partir do ponto mais elevado do pronoto. Ápice ultrapassando a altura da base da $3^{\mathrm{a}}$ célula apical das tégminas.

Tégminas com a veia $\mathrm{R} 1$ originando-se na $1^{\mathrm{a}}$ célula discoidal,

Genitália. Edeago plano-convexo, achatado ântero-posteriormente, notadamente na porção apical; face dorsal um pouco escavada, com uma fileira de dentículos bem desenvolvidos ao longo dos bordos da escavação, paralelas entre si. Parâmeros pouco achatados lateralmente na metade distal e abruptamente constrictos no bordo inferior ao nível do quarto distal; ápice fusiforme, mais esclerotinizado, discretamente curvado para dentro e com uma margem cortante nos bordos superior e inferior; pilosidade longa e imbricada para dentro nos bordos superior e inferior, ao nível da constrição pré-apical. Placas laterais do pigóforo com o dente apical bulbiforme, situado no ângulo posterior; dente lateral bem desenvolvido, localizado no terço mediano, diagonalmente dirigido para baixo, com o ápice arredondado e com um dentículo curvado também para baixo. Placa subgenital subretangular, quase duas vezes mais longa que larga medianamente.

Fêmea. Semelhante ao macho, apenas um pouco maior. Material examinado. Brasil, Amapá: Serra do Navio, IX.1972 (K. Lenko), 1 fêmea (DZUP); Pará: Belém, 1959 (L. Deane), 1 fêmea (MZUSP; identificado como C. mulsa RemesLenicov, A.M.M. Remes-Lenicov det.); Belém, IX.1964 (E. Dente), 1 fêmea (MZUSP); Óbidos, 1940 (sem coletor), 1 fêmea (MZUSP); Óbidos, VIII.1940 (sem coletor), 1 fêmea (MZUSP; identificado como C. mulsa Remes-Lenicov, A.M.M. RemesLenicov det.); Óbidos, XI.1953 (F.M. Oliveira), 3 fêmeas (DZUP; um exemplar identificado como C. affinis Fairmaire, A.M. Sakakibara det. e um exemplar identificado como C. affinis Fairmaire, A.M. Sakakibara det. e como C. mulsa Remes-Lenicov, A.M.M. Remes-Lenicov det.); Óbidos, IX.1954 (F.M. Oliveira), 1 fêmea (DZUP; identificado como C. affinis Fairmaire, A.M. Sakakibara det.); Óbidos, Baixo Amazonas, sem data (sem coletor), 1 fêmea (MZUSP); Amazonas: Fonte Boa, sem data (sem coletor), 1 fêmea (MZUSP; identificado como C. mulsa RemesLenicov, A.M.M. Remes-Lenicov det.); Manaus, reserva Ducke, 1.X.1976 (N.D. Penny), 1 fêmea (INPA; holótipo); Manaus, reserva Ducke, 11.XI.1976 (N.D. Penny), 1 macho (INPA); Itacoatiara, I.1965 (sem coletor), 1 fêmea (MZUSP); Manacapuru, 5.IV.1957 (Elias \& Roppa), 1 fêmea (MN); Tefé, sem data (sem coletor), 1 macho (MZUSP); Tabatinga, V.1957 (E.S. Lima), 1 fêmea (FCNM; identificado como C. affinis Fairmaire, A.M. Sakakibara det. e como C. mulsa Remes-Lenicov, A.M.M. Remes-Lenicov det.); Tabatinga, IX.1958 (E. Lima), 1 fêmea (CACS); Borba/Jutaí, BR 319, km 378, 31.X.1977 (J. Becker), 1 fêmea (MN); Mato Grosso: Sinop, X.1975 (M. Alvarenga), 1 fêmea (DZUP); Chapada dos Guimarães, "malaise", 19-21.XI.1983 (Exc. Dep. Zool. UFPR, Polonoroeste), 1 fêmea (DZUP). Peru, Ucayali: Pucallpa, VI.1951 (sem coletor), 1 fêmea (DZUP); Madre de Dios: Z.R. Tambopata, 23.VI.1984 (E. Pérez), 1 fêmea (MHNJP). (Todos os exemplares examinados pertencem à série-tipo).

Distribuição geográfica. BRAsil: Pará (Remes-Lenicov 1973), Amapá, Amazonas e Mato Grosso (Andrade 2002). Peru: Ucayali e Madre de Dios (ANDRADE 2002).

Localidade-tipo. Brasil, Amazonas: Manaus, reserva Ducke.

Notas sobre os tipos. O holótipo fêmea está depositado no INPA, em bom estado de conservação, alfinetado e com o abdome não dissecado. Faltam no exemplar trocanter, fêmur, tíbia e tarso II direitos. Existem um parátipo fêmea na coleção CACS, um parátipo fêmea na FCNM, um parátipo macho no

Revista Brasileira de Zoologia 21 (4): 671-738, dezembro 2004 
INPA, um parátipo fêmea no MHNJP, dois parátipos fêmeas no $\mathrm{MN}$, um parátipo macho e oito parátipos fêmeas no MZUSP e oito parátipos fêmeas na DZUP.

Planta hospedeira. Desconhecida.

Comentários. Foram observadas variações na aparência da sutura coronal e no grau de extensão do ápice do pronoto com relação a altura da base da $3^{\text {a }}$ célula apical das tégminas.

Esta espécie é muito próxima de $C$. mulsa ao nível da genitália masculina, porém distinta pela conformação e esculturação do pronoto.

Difere das demais espécies notadamente pela forte elevação do pronoto atrás do espaço entre os processos supraumerais.

\section{Ceresa uruguayensis Berg, 1883}

Figs 30-36

Ceresa uruguayensis Berg, 1883: 286; Metcalf \& Wade, 1965: 867 (cat., = C. ustulata Fairmaire, 1846); Remes-Lenicov, 1973: 114, lám. XXIII, figs 168 a 176 (gen. masc. fem.); McKamey, 1998: 246 (cat.).

Medidas. Macho (lectótipo)/fêmea (paralectótipo). Largura da cabeça: 2,16/2,48; comprimento da cabeça: 1,00/1,20; distância entre os ângulos umerais: 2,16/2,48; distância entre os ápices dos processos supra-umerais: 3,60/4,20; comprimento do pronoto: 5,25/6,00; comprimento total: $6,33 / 6,83$.

Descrição. Macho. Coloração geral ferruginosa. Máculas na cabeça, faixa nos lados do metopídio e nas faces anterior e dorsal dos processos supra-umerais, carena dorsal até o ponto mais elevado do pronoto, duas faixas que partem da face posterior dos processos supra-umerais e circundam as áreas semicirculares e anel pré-apical no processo pronotal posterior, esbranquiçadas; face ventral e porção distal da face dorsal dos processos supra-umerais e processo pronotal posterior, acastanhados; ápices dos processos supra-umerais e do pronoto negros. Tégminas hialinas, veias $\mathrm{R}+\mathrm{M}$ e $\mathrm{R}$ amareladas, as demais acastanhadas; margem costal maculada ao nível das $1^{\mathrm{a}}$ e $2^{\mathrm{a}}$ células apicais; limbo escurecido. Região ventral do corpo e pernas amareladas.

Cabeça com a superfície fracamente estriada, lisa no frontoclípeo e nos lóbulos supra-antenais. Sutura coronal não atingindo a base do frontoclípeo. Espaço interocelar convexo, espaços ocelo-oculares planos. Lóbulos supra-antenais escavados, com as margens sinuosas. Frontoclípeo sublosângico, metade distal com os bordos laterais inteiros e dirigida para baixo.

Pronoto com pontuação heterogênea, não abaulado nas regiões adjacentes às impressões semicirculares, fracamente elevado atrás do espaço entre os processos supra-umerais, levemente em declive e afilado para o ápice após o ponto mais elevado e não constricto ao nível do ângulo interno das tégminas. Metopídio trapezoidal, com as impressões musculares em forma de L invertido. Lóbulos pós-oculares com a superfície corrugada, sem modificações ao nível do ângulo externo dos olhos. Sulcos supra-umerais bem marcados, regiões supra-umerais com a su- perfície pontuada. Processos supra-umerais desenvolvidos, levemente prismáticos na metade basal e cônicos na metade distal, curvos na metade distal, dirigidos para os lados, inclinados para cima e com os ápices voltados para os lados e para trás; face dorsal arredondada, face posterior pontuada na metade basal e lisa na metade distal; espaço entre eles convexo; arestas A e P ausentes na metade distal; aresta $\mathrm{M}$ pronunciada como um leve intumescimento somente na metade basal; espaços anterior e posterior a aresta $\mathrm{M}$ normais. Impressões semicirculares bem distintas, áreas semicirculares planas e bem impressas. Carena dorsal cortante a partir do ponto mais elevado do pronoto. Ápice não atingindo a altura da base da $3^{\text {a }}$ célula apical das tégminas.

Tégminas com a veia $\mathrm{R} 1$ originando-se na $1^{\mathrm{a}}$ célula discoidal.

Genitália. Edeago subcilíndrico, afilado distalmente, com o ápice bulbiforme; face dorsal com dentículos escamiformes distribuídos em mosaico nos dois quartos medianos, mais proeminentes na porção superior. Parâmeros achatados lateralmente, notadamente na metade distal, curvados para cima e para dentro no terço distal; ápice em forma de faca, mais esclerotinizado, com a margem do bordo superior mais cortante; pilosidade escassa e heterogênea distribuída ao longo do bordo inferior e da face interna, ao nível do quarto distal. Placas laterais do pigóforo com o dente apical intumescido, situado no ângulo central; dente lateral bem desenvolvido, localizado no terço mediano, sinuoso e diagonalmente dirigido para baixo, com o ápice agudo e discretamente curvado também para baixo. Placa subgenital subtriangular, quase duas vezes mais longa que larga basalmente.

Fêmea. Semelhante ao macho, apenas um pouco maior.

Material examinado. Argentina, Entre Ríos: Parque Nacional El Palmar, 12.I.1981 (Bordón), 1 fêmea (CB); San Luis: Merlo, 24.I.1958 (Willink \& Tonsic), 1 fêmea (FML). UruguaI, Sem indicação de Departamento: "Banda Oriental", sem data (sem coletor), 1 macho e 1 fêmea (FCNM; lectótipo e paralectótipo, cf. em Notas sobre os tipos).

Distribuição geográfica. Argentina: Jujuy, Salta, Córdoba, Entre Ríos, San Luis e Buenos Aires (Remes-Lenicov 1973). URuGUAI: "Banda Oriental" (BERg 1883).

Localidade-tipo. “...en la Banda Oriental del Uruguay, cerca del Rio Corralito,..." (BERG 1883).

É possível que uma etiqueta circular azul apensa aos tipos, com o número 17.43 , seja referente a algum registro existente na FCNM e possa precisar mais a localidade-tipo.

Notas sobre os tipos. Foram examinados dois síntipos depositados na FCNM, ambos montados no mesmo alfinete. Designa-se aqui o exemplar superior, macho, como o lectótipo e o inferior, fêmea, como paralectótipo.

O lectótipo se encontra em razoável estado de conservação, com o abdome dissecado, azinhavre no alfinete junto ao exemplar, pronoto um pouco deslocado e tégmina esquerda aberta.

Planta hospedeira. "Vive en la Acacia farnesiiana Will." (BERG 1883). 

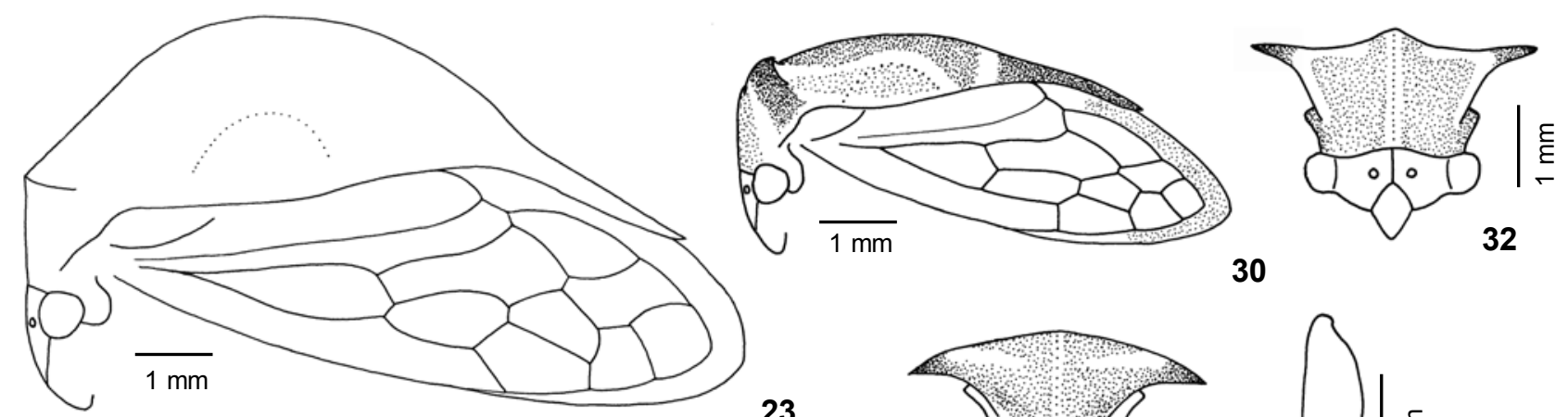

$1 \mathrm{~mm}$

30

32

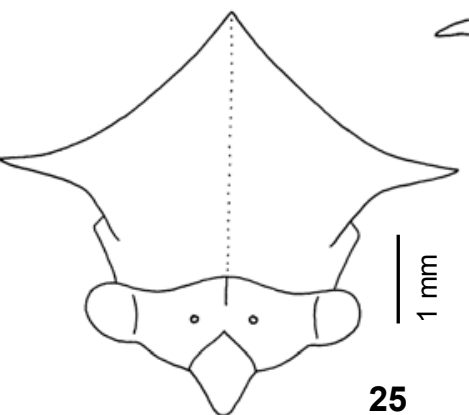

25
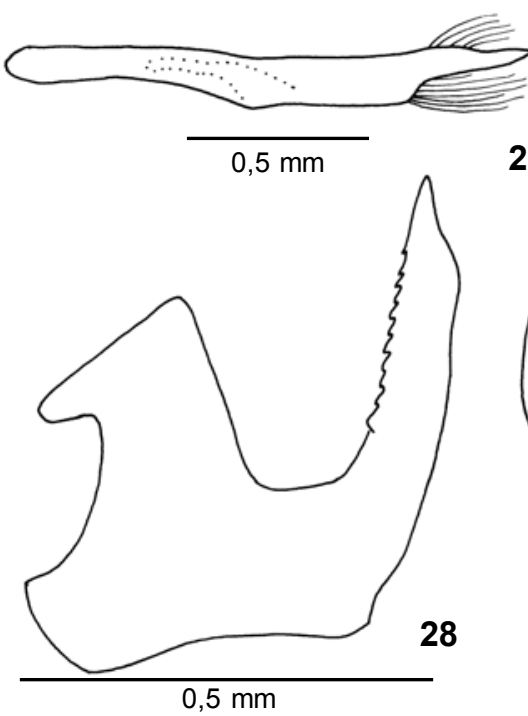

26

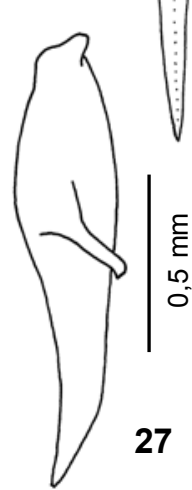

23
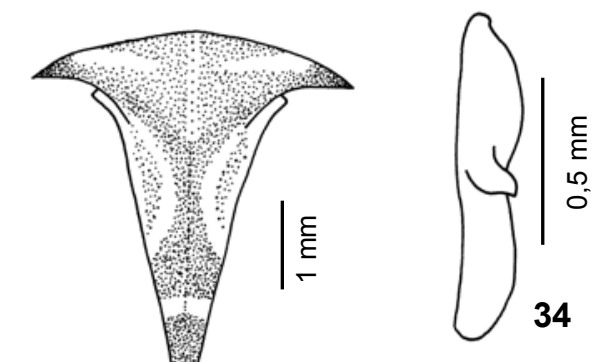

31

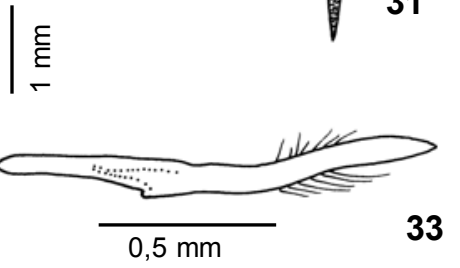

33

24

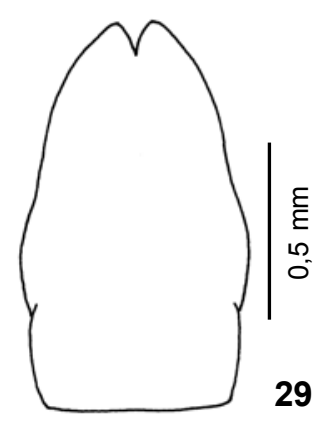

Figuras 23-36. (23-29) Ceresa amazonica: (23) cabeça, pronoto e tégmina, vista lateral; (24) pronoto, vista dorsal; (25) cabeça e pronoto, vista frontal; (26) parâmero esquerdo, vista lateral; (27) placa lateral esquerda do pigóforo, vista lateral; (28) edeago, vista lateral; (29) placa subgenital, vista ventral; (30-36) Ceresa uruguayensis: (30) cabeça, pronoto e tégmina, vista lateral; (31) pronoto, vista dorsal; (32) cabeça e pronoto, vista frontal; (33) parâmero esquerdo, vista lateral; (34) placa lateral esquerda do pigóforo, vista lateral; (35) edeago, vista lateral; (36) placa subgenital, vista ventral.

Comentários. Goding (1929) colocou esta espécie na sinonímia de C. ustulata Fairmaire, 1846. O estudo comparativo do lectótipo de C. uruguayensis com a descrição original e com um exemplar fêmea comparado com o tipo de C. ustulata mostrou que se tratam de espécies distintas, corroborando a interpretação de C. uruguayensis por Remes-Lenicov (1973).

Foram observadas variações na aparência da sutura coronal e das impressões semicirculares.

Difere das demais espécies notadamente pelo padrão de coloração.

Revista Brasileira de Zoologia 21 (4): 671-738, dezembro 2004 


\section{Ceresa pauperata Berg, 1883 sp. rev. Figs $37-43$}

Ceresa pauperata Berg, 1883: 287. sp. rev.

Ceresa pauperata; Metcalf \& Wade, 1965: 865 (cat., = C. extensa Walker, 1858); McKamey, 1998: 245 (cat., = C. extensa Walker, 1858).

Ceresa extensa; Remes-Lenicov, 1973: 72, lám. VI, figs 32 a 40 (rdescr., gen. masc. fem.), non C. extensa Walker, 1858.

Medidas. Macho (paralectótipo)/fêmea (lectótipo). Largura da cabeça: 2,52/2,72; comprimento da cabeça: 1,26/1,36; distância entre os ângulos umerais: 2,76/2,92; distância entre os ápices dos processos supra-umerais: 4,00/3,96; comprimento do pronoto: 5,83/6,50; comprimento total: 6,33/6,83.

Descrição. Macho. Coloração geral amarelada. Face ventral dos processos supra-umerais acastanhada; porção apical dos processos supra-umerais enegrecida, ápice do pronoto negro. Tégminas hialinas, veias amareladas. Região ventral do corpo e pernas amareladas.

Cabeça com a superfície fortemente estriada, com algumas pontuações, corrugada no frontoclípeo e nos lóbulos supra-antenais. Sutura coronal atingindo a base do frontoclípeo. Espaço interocelar convexo, espaços ocelo-oculares planos. Lóbulos supra-antenais planos, com as margens sinuosas. Frontoclípeo sublosângico, metade distal com os bordos laterais inteiros e dirigida fortemente para trás.

Pronoto com pontuação homogênea, não abaulado nas regiões adjacentes às impressões semicirculares, fracamente elevado atrás do espaço entre os processos supra-umerais, levemente em declive e afilado para o ápice após o ponto mais elevado e não constricto ao nível do ângulo interno das tégminas. Metopídio trapezoidal, com as impressões musculares em forma de L invertido. Lóbulos pós-oculares com a superfície pontuada, calosos ao nível do ângulo externo dos olhos. Sulcos supra-umerais bem marcados, regiões supra-umerais com a superfície pontuada. Processos supra-umerais desenvolvidos, levemente prismáticos na metade basal e cônicos na metade distal, retos na metade distal, dirigidos para os lados, sem inclinação e com os ápices voltados para os lados; face dorsal arredondada, face posterior pontuada na metade basal e corrugada na metade distal; espaço entre eles convexo; arestas A e $\mathrm{P}$ ausentes na metade distal; aresta $\mathrm{M}$ pronunciada como um leve intumescimento somente na metade basal; espaços anterior e posterior a aresta $\mathrm{M}$ normais. Impressões semicirculares pouco distintas, áreas semicirculares planas e bem impressas. Carena dorsal arredondada a partir do ponto mais elevado do pronoto, cortante apenas em sua porção distal. Ápice ultrapassando a altura da base da $3^{\mathrm{a}}$ célula apical das tégminas.

Tégminas com a veia $\mathrm{R} 1$ originando-se na $1^{\mathrm{a}}$ célula discoidal.

Genitália. Edeago achatado ântero-posteriormente, afilado para o ápice; face dorsal com uma fileira dupla de dentículos de cada lado nos dois quartos medianos, um pouco divergentes entre si. Parâmeros subcilíndricos, dilatados nos dois quartos medianos, abruptamente achatados lateralmente, constrictos e um pouco curvados para dentro ao nível do quarto distal; ápice laminar, distalmente truncado, mais esclerotinizado e discretamente curvado para fora; pilosidade proeminente na face interna, tufosa, e ao longo do bordo superior, ao nível do quarto distal. Placas laterais do pigóforo com o dente apical intumescido, situado no ângulo central; dente lateral bem desenvolvido, localizado no terço superior, diagonalmente dirigido para baixo e com o ápice arredondado. Placa subgenital quase duas vezes mais longa que larga basalmente, estreitando-se após a região mediana.

Fêmea. Semelhante ao macho, apenas um pouco maior. Material examinado. Argentina, Buenos Aires: Tandil, XII.1943 (Bachman), 1 macho (FCNM; identificado como C. extensa Walker, A.M.M. Remes-Lenicov det.); Sierra de la Ventana, 16.II.1965 (Torres \& Ferreira), 1 fêmea (FCNM; identificado como C. extensa Walker, A.M.M. Remes-Lenicov det.). URUGual, Sem indicação de Departamento: "Banda Oriental", sem data (sem coletor), 1 macho e 1 fêmea (FCNM; paralectótipo e lectótipo, cf. em Notas sobre os tipos).

Distribuição geográfica. Argentina: Tucumán, Entre Ríos, Buenos Aires, La Pampa, Neuquén e Río Negro (Remes-Lenicov 1973). URUGUaI: "Banda Oriental" (Berg 1883).

Localidade-tipo. “...en la misma época y la misma especie de árbol que la Ceresa anterior." (BERg 1883). Esta afirmação sugere que os tipos de $C$. pauperata sejam procedentes da mesma localidade dos tipos de C. uruguayensis.

É possível que uma etiqueta circular azul apensa aos tipos, com o número 17.42, seja referente a algum registro existente na FCNM e possa precisar mais a localidade-tipo.

Notas sobre os tipos. Foram examinados dois síntipos depositados na FCNM, ambos montados no mesmo alfinete. Designa-se aqui o exemplar inferior, fêmea, como lectótipo e o superior, macho, cujo abdome está dissecado, como paralectótipo.

O lectótipo se encontra em razoável estado de conservação, com azinhavre no alfinete junto ao exemplar e tégmina direita aberta.

O edeago do paralectótipo não se encontra no microtubo apenso ao alfinete.

Planta hospedeira. "...la misma especie de árbol que la Ceresa anterior." (BERG 1883). Esta afirmação nos reporta à descrição original de C. uruguayensis e permite referir que a planta hospedeira reconhecida pelo autor seja "...Acacia farnesiiana Will." (BERG 1883).

Comentários. FunKhouser (1927b) colocou esta espécie na sinonímia de C. extensa Walker, 1858. O estudo comparativo do lectótipo de $C$. pauperata com a descrição original e o lectótipo fêmea de C. extensa, depositado no BMNH, mostrou que se tratam de espécies distintas.

A interpretação de C. pauperata como C. extensa feita por Remes-Lenicov (1973) foi, sem dúvida, baseada na sinonímia proposta por Funkhouser (1927b). Segundo SAKAKIBARA (2002), C. extensa Walker classifica-se no gênero Ilithucia Stål, 1867. 
Foi observada variação no aspecto do espaço entre os processos supra-umerais e que alguns exemplares apresentam máculas escurecidas nas coxas.

Difere das demais espécies notadamente pela aparência fosca do tegumento, por apresentar os processos supra-umerais praticamente cônicos e o ápice do pronoto quase atingindo o ângulo externo da $3^{\mathrm{a}}$ célula apical das tégminas.

\section{Ceresa axillaris (Germar, 1835) Figs $44-50$}

Smilia axillaris Germar, 1835: 235.

Ceresa axillaris; Metcalf \& Wade, 1965: 844 (cat.); RemesLenicov, 1973: 88, lám. XII, figs 85 a 93 (rdescr., gen. masc. fem.); Kopp \& Yonke, 1979: 23 (list.); McKamey, 1998: 244 (cat.).

Medidas. Macho. Largura da cabeça: 2,68; comprimento da cabeça: 1,34; distância entre os ângulos umerais: 2,60; distância entre os ápices dos processos supra-umerais: 3,72 ; comprimento do pronoto: 6,42; comprimento total: 7,92.

Descrição. Macho. Coloração geral ferruginosa, com máculas amareladas. Margens dos lóbulos supra-antenais, região mediana das margens laterais do pronoto e da carena dorsal, faixas anterior e posterior à face ventral dos processos supra-umerais, faixas que partem da face posterior dos processos supra-umerais e circundam as áreas semicirculares e áreas semicirculares, amareladas; face ventral dos processos supraumerais, regiões supra-umerais e processo pronotal posterior escurecidos; porção distal dos processos supra-umerais acastanhada; ápices dos processos supra-umerais e do pronoto negros. Tégminas e veias ambarinas. Face ventral da cabeça e pleuras torácicas enegrecidas; esternos abdominais negros. Pernas ferruginosas, com as coxas maculadas de negro.

Cabeça com a superfície estriada na base e nos espaços ocelo-oculares, lisa nas demais regiões. Sutura coronal não atingindo a base do frontoclípeo. Espaço interocelar convexo, espaços ocelo-oculares deprimidos. Lóbulos supra-antenais escavados, com as margens sinuosas. Frontoclípeo sublosângico, metade distal com os bordos laterais chanfrados e dirigida para baixo.

Pronoto com pontuação homogênea, abaulado nas regiões adjacentes às impressões semicirculares, regularmente elevado atrás do espaço entre os processos supra-umerais, gradualmente em declive e afilado para o ápice após o ponto mais elevado e constricto ao nível do ângulo interno das tégminas. Metopídio trapezoidal, com as impressões musculares em forma de $\mathrm{V}$ invertido. Lóbulos pós-oculares com a superfície corrugada, sulcados ao nível do ângulo externo dos olhos. Sulcos supra-umerais bem marcados, regiões supra-umerais com a superfície lisa. Processos supra-umerais desenvolvidos, levemente prismáticos na metade basal e cônicos na metade distal, curvos na metade distal, dirigidos para os lados, inclinados para baixo e com os ápices voltados para os lados e para trás; face dorsal arredondada, face posterior pontuada na metade basal e lisa na metade distal; espaço entre eles convexo; arestas A e P ausentes na metade distal; aresta $\mathrm{M}$ pronunciada como um leve intumescimento somente na metade basal; espaços anterior e posterior a aresta $\mathrm{M}$ normais. Impressões semicirculares pouco distintas, áreas semicirculares planas e não impressas. Carena dorsal cortante a partir do ponto mais elevado do pronoto. Ápice não atingindo a altura da base da $3^{\text {a }}$ célula apical das tégminas.

Tégminas com a veia $\mathrm{R} 1$ originando-se na $1^{\mathrm{a}}$ célula discoidal.

Genitália. Edeago achatado ântero-posteriormente, afilado para o ápice; face dorsal com bandas laterais de dentículos escamiformes distribuídos em mosaico ao longo dos dois quartos medianos. Parâmeros achatados lateralmente na metade distal, fortemente curvados para cima, para dentro e constrictos pré-apicalmente no terço distal; ápice em forma de lança, mais esclerotinizado, laminar, com a ponta dirigida para trás; pilosidade longa e homogênea distribuída ao longo dos bordos superior e inferior, ao nível do quarto distal. Placas laterais do pigóforo com o dente apical fortemente intumescido, situado no ângulo central; dente lateral bem desenvolvido, localizado no terço mediano, diagonalmente dirigido para baixo e com o ápice arredondado. Placa subgenital mais de duas vezes longa que larga basalmente, distintamente constricta ao nível da região mediana.

Fêmea. Não examinada. Segundo Remes-Lenicov (1973), “...en general la coloración es más clara.".

Material examinado. Brasil, São Paulo: São Paulo, Parque Jabaquara, IX.1931 (sem coletor), 3 machos (MZUSP). Argentina, Salta: San Lorenzo, 24.XII.1939 (Denier), 1 macho (FCNM); San Lorenzo, XI.1959 (A. Martinez), 1 macho (MZUSP); Catamarca: El Rodeo, 28.I.1958 (Golbach), 1 macho (FML); Tucumán: San Pedro de Colalao, I.1949 (Arnau), 1 macho (MZUSP); San Pedro de Colalao, II.1949 (Arnau), 4 machos (MZUSP).

Distribuição geográfica. Brasil: São Paulo. Bolívia: Tarija (Remes-Lenicov 1973). Argentina: Jujuy, Salta, Catamarca e Tucumán (Remes-Lenicov 1973).

Localidade-tipo. "Habitat in Brasilia. Bescke." (Germar 1835). É possível precisar um pouco mais a sumariedade desta indicação. Segundo Papavero (1971-1973) existiram dois "Besckes" que coletaram na América do Sul, o pai Christian Friedrich Carl Bescke e seu filho Carl Heinrich Bescke. O primeiro realizou viagem em 1821 às cidades de Buenos Aires, Rio de Janeiro na Guanabara (sic) e Salvador na Bahia, e o segundo se estabeleceu no Estado do Rio de Janeiro entre ? 1831 e 1851, especialmente em Nova Friburgo. A indicação original não permite saber qual dos dois teria enviado material a E.F. Germar, mas a informação "...in Brasilia." sugere que a localidade-tipo seja a cidade do Rio de Janeiro, Nova Friburgo ou Salvador.

Notas sobre o(s) tipo(s). Segundo J.C.M. Carvalho (comunicação pessoal), os tipos das espécies descritas por E.F. Germar estariam depositados no "Museum für Naturkunde der Humboldt-Universität zu Berlin" (Berlin). Em resposta a consulta feita a esta instituição, U. Göllner-Scheiding (comunica-

Revista Brasileira de Zoologia 21 (4): 671-738, dezembro 2004 
ção pessoal) informou: “...da sich die Germar-Typen nur in wenigen Exemplaren in unserer Sammlung befinden. Der Hauptteil der Typen befand sich in Lemberg und ist meines Wissens jetzt in der Sammlung des Zoologischen Museums in Warschau. Ich würde Ihnen raten, sich na (sic) folgende Adresse zu wenden:".

Uma consulta posterior feita a "Polska Akademia Nauk" (Warzawa) também foi infrutífera. S.A. Slipinski (comunicação pessoal) informou: “...We have checked all our Membracidae specimens including those from the former Stettin Collection - but unfortunately there are no Germar types among them. I could not inform you whether the specimens are lost or are $\mathrm{n}$ (sic) the different collection...".

Estas informações sugerem que os tipos das espécies descritas por E.F. Germar, ao menos os deste grupo, estejam provavelmente perdidos.

Planta hospedeira. Desconhecida.

Comentários. Esta espécie foi interpretada em consonância com Remes-Lenicov (1973). Entretanto, cabe ressaltar que embora a autora afirme que "...todos los ejemplares examinados por nosotros se ajustan muy bien a la descripición original...", na descrição de Germar (1835) lemos “...inter cornua concavoimpressum,...", o que contrasta com os exemplares examinados e descrições de Remes-Lenicov (1973) e do presente estudo.

Uma definição futura do tipo de Smilia axillaris Germar poderia alterar a interpretação adotada para a espécie.

Foram observadas variações na coloração, principalmente na região ventral do corpo, no padrão de pontuação do pronoto e na aparência das impressões e áreas semicirculares.

Difere das demais espécies notadamente pelos caracteres apresentados na chave.

\section{Ceresa stylata Remes-Lenicov, 1973}

\section{Figs 51-57}

Ceresa stylata Remes-Lenicov, 1973: 74, lám. VII, figs 41 a 48; McKamey, 1998: 246 (cat.).

Medidas. Macho/fêmea (alótipo). Largura da cabeça: 2,84/ 3,12; comprimento da cabeça: $1,32 / 1,48$; distância entre os ângulos umerais: 2,92/3,20; distância entre os ápices dos processos supra-umerais: 4,00/4,60; comprimento do pronoto: 7,00/7,50; comprimento total: 7,83/8,33.

Descrição. Macho. Coloração geral amarelada, com máculas esbranquiçadas. Face ventral e porção distal da face posterior dos processos supra-umerais e regiões supra-umerais, escurecidas; aresta $\mathrm{M}$ esbranquiçada; ápices dos processos supra-umerais acastanhados, ápice do pronoto negro. Tégminas hialinas, veias amareladas. Região ventral do corpo amarelada, pleuras torácicas e esternos abdominais com máculas enegrecidas. Pernas amareladas, com as coxas maculadas de negro.

Cabeça com a superfície estriada na base e nos espaços ocelo-oculares, lisa nas demais regiões. Sutura coronal atingindo a base do frontoclípeo. Espaço interocelar convexo, espaços ocelo-oculares planos. Lóbulos supra-antenais escavados, com as margens sinuosas. Frontoclípeo sublosângico, metade distal com os bordos laterais chanfrados e dirigida para baixo.

Pronoto com pontuação homogênea, não abaulado nas regiões adjacentes às impressões semicirculares, regularmente elevado atrás do espaço entre os processos supra-umerais, gradualmente em declive e afilado para o ápice após o ponto mais elevado e não constricto ao nível do ângulo interno das tégminas. Metopídio trapezoidal, com as impressões musculares em forma de $\mathrm{V}$ invertido. Lóbulos pós-oculares com a superfície corrugada, sem modificações ao nível do ângulo externo dos olhos. Sulcos supra-umerais bem marcados, regiões supra-umerais com a superfície pontuada. Processos supra-umerais desenvolvidos, levemente prismáticos na metade basal e cônicos na metade distal, retos na metade distal, dirigidos para os lados, inclinados para baixo e com os ápices voltados para os lados; face dorsal arredondada, face posterior pontuada na metade basal e corrugada na metade distal; espaço entre eles convexo; arestas A e P ausentes na metade distal; aresta M pronunciada como um leve intumescimento somente na metade basal; espaços anterior e posterior a aresta M normais. Impressões semicirculares pouco distintas, áreas semicirculares planas e não impressas. Carena dorsal cortante a partir do ponto mais elevado do pronoto. Ápice atingindo a altura da base da $3^{\mathrm{a}}$ célula apical das tégminas.

Tégminas com a veia $\mathrm{R} 1$ originando-se na $1^{\mathrm{a}}$ célula discoidal.

Genitália. Edeago achatado ântero-posteriormente, com o ápice arredondado; face dorsal com uma fileira de dentículos bem desenvolvidos de cada lado na metade distal e dentículos pouco desenvolvidos distribuídos em mosaico na metade basal. Parâmeros subcilíndricos, um pouco achatados lateralmente e com uma escavação no bordo superior ao nível do quarto distal, cujas margens se unem próximo ao ápice, formando uma estrutura de aspecto navicular; ápice laminar, diagonalmente truncado, com a margem cortante; pilosidade proeminente nas faces interna e externa, ao nível do quarto distal. Placas laterais do pigóforo com o dente apical intumescido, situado no ângulo central; dente lateral bem desenvolvido, localizado no terço mediano, subtriangular, diagonalmente dirigido para baixo, com o ápice afilado e curvado também para baixo. Placa subgenital mais de duas vezes longa que larga basalmente, estreitando-se após a região mediana.

Fêmea. Semelhante ao macho, apenas um pouco maior. Material examinado. Brasil, Minas Gerais: Ouro Preto, Topázios, 22.II.1962 (J. Bechyné), 1 fêmea (MZUSP); Barbacena, 14-16.XI.1962 (M. Alvarenga), 1 fêmea (DZUP); Poços de Caldas, campo a jusante do Véu da Noiva, 3.XII.1966 (J. Becker \& O. Roppa), 1 macho (MN); São Paulo: São Carlos, 1944 (M.A. Vulcano \& J. Lane), 1 fêmea (MZUSP); Mairiporã, 4-13.I.1967 (C. Costa), 3 machos e 2 fêmeas (MZUSP); São Paulo, Ipiranga, I.1907 (Lüd.), 1 fêmea (MZUSP; identificado como C. vitulus (Fabricius)); São Paulo, Ipiranga, I.1932 (R. Spitz), 1 fêmea 


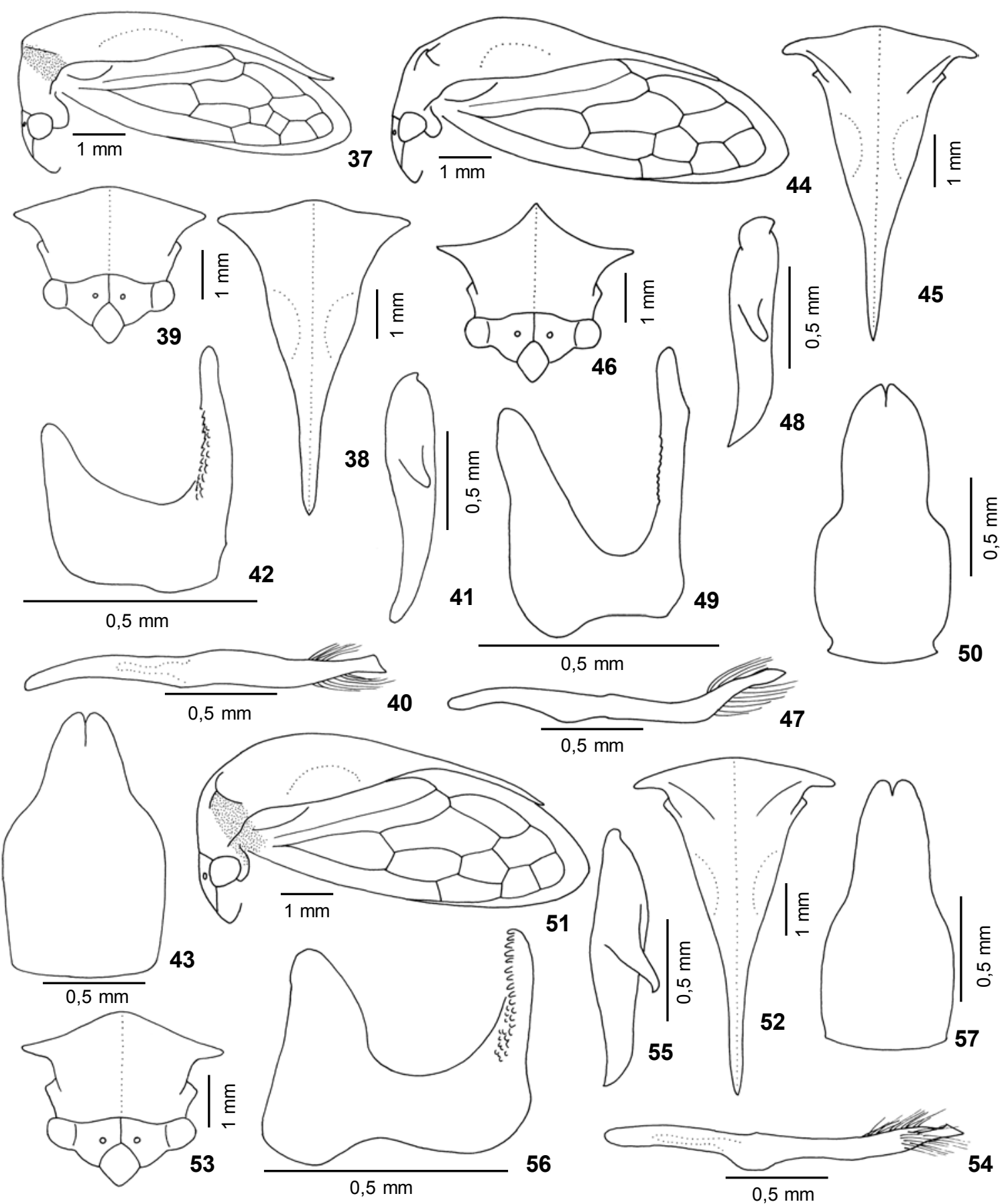

Figuras 37-57. (37-43) Ceresa pauperata: (37) cabeça, pronoto e tégmina, vista lateral; (38) pronoto, vista dorsal; (39) cabeça e pronoto, vista frontal; (40) parâmero esquerdo, vista lateral; (41) placa lateral esquerda do pigóforo, vista lateral; (42) edeago, vista lateral; (43) placa subgenital, vista ventral; (44-50) Ceresa axillaris: (44) cabeça, pronoto e tégmina, vista lateral; (45) pronoto, vista dorsal; (46) cabeça e pronoto, vista frontal; (47) parâmero esquerdo, vista lateral; (48) placa lateral esquerda do pigóforo, vista lateral; (49) edeago, vista lateral; (50) placa subgenital, vista ventral; (51-57) Ceresa stylata: (51) cabeça, pronoto e tégmina, vista lateral; (52) pronoto, vista dorsal; (53) cabeça e pronoto, vista frontal; (54) parâmero esquerdo, vista lateral; (55) placa lateral esquerda do pigóforo, vista lateral; (56) edeago, vista lateral; (57) placa subgenital, vista ventral. 
(MZUSP); São Paulo, M. Governo, 1939 (sem coletor), 1 macho (MZUSP); São Paulo, Santo Amaro, XII.1941 (J. Lane), 1 macho e 2 fêmeas (MZUSP); Rio de Janeiro: Rio de Janeiro, cascatinha da Tijuca, 21.IV.1944 (M.A. Vulcano), 1 fêmea (MZUSP); Paraná: Ponta Grossa, Vila Velha, 19.I.1969 (J.S. Moure), 2 fêmeas (DZUP); Guarapuava, Santa Clara, 56.XII.1983 (Exc. Dep. Zool. UFPR), 1 macho (DZUP). ARGENTINA. Misiones: Santa Inés, 13.XII.1941 (Birabén \& Bezzi), 1 fêmea (FCNM; alótipo).

Distribuição geográfica. Brasil: Minas Gerais, São Paulo, Rio de Janeiro e Paraná. Bolívia: Santa Cruz (Remes-Lenicov 1973). Argentina: Misiones e Buenos Aires (Remes-Lenicov 1973).

Localidade-tipo. “...Dto. Concepción, Santa María, Misiones, Argentina." (Remes-Lenicov 1973).

Notas sobre os tipos. Segundo a descrição original, o holótipo macho está depositado no MACNBR. Foi examinado o alótipo fêmea, depositado na FCNM. O exemplar se encontra em bom estado de conservação, montado em cartão, com a região ventral da cabeça, do tórax e pernas coladas no cartão e com o abdome não dissecado. Faltam tíbia e tarso II em ambos os lados. Ainda segundo a descrição original, existem mais quatro parátipos fêmeas também na FCNM.

Planta hospedeira. Desconhecida.

Comentários. Esta espécie foi interpretada com base no alótipo fêmea e na descrição e ilustrações originais.

Foram observadas variações na coloração, principalmente na região ventral do corpo, na escultura da superfície da cabeça, às vezes mais amplamente estriada, na inclinação dos processos supra-umerais e no grau de extensão do ápice do pronoto com relação à altura da base da $3^{\mathrm{a}}$ célula apical das tégminas.

Esta espécie é muito semelhante a C. axillaris (Germar), como interpretada por RemEs-Lenicov (1973) e no presente estudo. Difere, além de outros caracteres referidos na chave, pelo padrão de coloração e, notadamente, pelo aspecto digitiforme dos processos supra-umerais e por apresentar a metade distal da face posterior dos mesmos nitidamente corrugada, bem como pelas diferenças ao nível das estruturas da genitália masculina.

\section{Ceresa distans Butler, 1877 sp. rev. Figs 58-64}

Ceresa distans Butler, 1877: 218. sp. rev.

Ceresa distans; Metcalf \& Wade, 1965: 862 (cat., = C. vitulus (Fabricius, 1775)); Broomfield, 1971: 346 (tip.); RemesLenicov, 1973: 88 (not.); McKamey, 1998: 246 (cat., $=C$. vitulus (Fabricius, 1775)).

Ceresa vitulus; Caldwell, 1949: 500, pl. 18, fig. 5 (rdescr., gen. masc.), non C. vitulus (Fabricius, 1775).

Ceresa peruensis Remes-Lenicov, 1973: 82, lám. X, figs 67 a 75 . syn. nov.

Ceresa peruensis; McKamey, 1998: 245 (cat.).

Medidas. Macho/fêmea. Largura da cabeça: 3,04/3,28; comprimento da cabeça: 1,52/1,64; distância entre os ângulos umerais: 3,12/3,40; distância entre os ápices dos processos supra-umerais: 4,60/5,50; comprimento do pronoto: $6,75 / 7,50$; comprimento total: $8,67 / 8,75$.

Descrição. Macho. Coloração geral ferruginosa, escurecida no fundo das pontuações, na metade distal da carena dorsal e no processo pronotal posterior, mais clara na cabeça e no metopídio, com máculas amareladas nas regiões adjacentes às impressões semicirculares e nas áreas semicirculares. Face ventral e porção distal da face posterior dos processos supra-umerais e regiões supra-umerais, acastanhadas; aresta $\mathrm{M}$ amarelada; ápices dos processos supra-umerais e do pronoto negros. Tégminas e veias ambarinas. Região ventral do corpo amarelada, pleuras torácicas e esternos abdominais com máculas enegrecidas. Pernas amareladas, coxas com máculas enegrecidas.

Cabeça com a superfície fortemente estriada, corrugada no frontoclípeo e nos lóbulos supra-antenais. Sutura coronal atingindo a base do frontoclípeo, mais marcada junto à margem superior. Espaço interocelar convexo, espaços ocelo-oculares deprimidos. Lóbulos supra-antenais escavados, com as margens sinuosas. Frontoclípeo sublosângico, metade distal com os bordos laterais chanfrados e dirigida para baixo.

Pronoto com pontuação homogênea, não abaulado nas regiões adjacentes às impressões semicirculares, regularmente elevado atrás do espaço entre os processos supra-umerais, gradualmente em declive e afilado para o ápice após o ponto mais elevado e constricto ao nível do ângulo interno das tégminas. Metopídio trapezoidal, com as impressões musculares em forma de $\mathrm{V}$ invertido. Lóbulos pós-oculares com a superfície corrugada, sulcados ao nível do ângulo externo dos olhos. Sulcos supraumerais bem marcados, regiões supra-umerais com a superfície pontuada. Processos supra-umerais desenvolvidos, prismáticos na metade basal e cônicos na metade distal, retos na metade distal, dirigidos para os lados, inclinados para baixo e com os ápices voltados para os lados; face dorsal arredondada, face posterior pontuada na metade basal e lisa na metade distal; espaço entre eles convexo; arestas A e P ausentes na metade distal; aresta $\mathrm{M}$ pronunciada somente na metade basal; espaços anterior $\mathrm{e}$ posterior a aresta $\mathrm{M}$ normais. Impressões semicirculares pouco distintas, áreas semicirculares planas e não impressas. Carena dorsal cortante a partir do ponto mais elevado do pronoto. Ápice atingindo a altura da base da $3^{\mathrm{a}}$ célula apical das tégminas.

Tégminas com a veia $\mathrm{R} 1$ originando-se na $1^{\mathrm{a}}$ célula discoidal.

Genitália. Edeago achatado ântero-posteriormente, notadamente na metade distal; face dorsal um pouco escavada, com uma fileira dupla e irregular de dentículos de cada lado ao longo dos três quartos basais, divergentes entre si e delimitando denticulação em mosaico na porção superior. Parâmeros achatados lateralmente, inclinados para cima e um pouco curvados para fora na região mediana, e abruptamente constrictos no bordo inferior ao nível do terço distal; ápice em forma aproximada de foice, mais esclerotinizado, com a ponta voltada para baixo; pilosidade proeminente ao nível da 
constrição, tufosa, e ao longo do bordo superior do quarto distal. Placas laterais do pigóforo com o dente apical inconspícuo, situado no ângulo central; dente lateral bem desenvolvido, localizado no terço mediano, fracamente dirigido para baixo e com o ápice arredondado. Placa subgenital quase duas vezes mais longa que larga basalmente, estreitando-se após a região mediana.

Fêmea. Semelhante ao macho, apenas um pouco maior. Material examinado. Colômbia, Cundinamarca: Villeta, 19.III.1965 (J.A. Ramos), 2 machos (UPR); Bogotá, sem data (Lindig), 1 macho e 4 fêmeas (MZUSP); Meta: Villavicencio, 1.XI.1965 (J.A. Ramos), 1 fêmea (UPR). SuRINAmE, Saramacca: Paramaribo, 4.IV.1927 (sem coletor), 1 fêmea (CU; identificado como C. sallei Stål, W.D. Funkhouser det.); Paramaribo, 6.IV.1927 (sem coletor), 1 macho e 2 fêmeas (CU; identificado como C. sallei Stål, W.D. Funkhouser det.); Marowijne: Moengo, Boven, Cottica, 13.V.1927 (sem coletor), 2 machos e 2 fêmeas (CU; identificado como C. sallei Stål, W.D. Funkhouser det.); Moengo, Boven, Cottica, 16.V.1927 (sem coletor), 2 machos e 1 fêmea (CU; identificado como C. sallei Stål, W.D. Funkhouser det.); Moengo, Boven, Cottica, 17.V.1927 (sem coletor), 1 macho (CU; identificado como C. sallei Stål, W.D. Funkhouser det.); Sem indicação de Distrito: Sint Barbara, Pln. Surinan, 15.IV.1927 (sem coletor), 1 macho (CU; identificado como C. sallei Stål, W.D. Funkhouser det.). Brasil, Pará: Belém, IX.1964 (E. Dente), 1 macho e 5 fêmeas (MZUSP); Jacareacanga, XII.1968 (M. Alvarenga), 1 fêmea (DZUP); sem indicação de localidade, sem data (Baker), 2 machos e 3 fêmeas (CU; identificado como C. sallei Stål, W.D. Funkhouser det.); Amazonas: Rio Preto, Manaos (sic), 5.VII.1964 (sem coletor), 1 macho (FCNM; parátipo de $C$. peruensis Remes-Lenicov); Manaus, estrada do Aleixo, km 7, 23.IV.1976 (L. Albuquerque), 1 fêmea (INPA; identificado com C. distans Butler, A.M. Sakakibara det.); Manaus, estrada do Aleixo, km 7, 23.IV.1976 (I.S. Gorayeb), 1 macho e 1 fêmea (INPA; identificado com C. distans Butler, A.M. Sakakibara det.); Manaus, estrada do Aleixo, km 7, 23.IV.1976 (B. Mascarenhas), 1 fêmea (INPA; identificado como C. distans Butler, A.M. Sakakibara det.); Manaus, Aleixo, 29.I.1981 (U.C. Barbosa), 1 macho (INPA); Itacoatiara, 15.VI.1952 (O.M. Rego), 1 macho (DZUP); Careiro, 3.VIII.1961 (Mozarth), 2 machos e 1 fêmea (INPA; identificado como C. distans Butler, A.M. Sakakibara det.); Tefé, XI.1976 (G.S. Andrade), 1 macho (CACS); Tabatinga, VII.1958 (E. Lima), 2 fêmeas (CACS); Tabatinga, 16.II.1961 (Mozarth), 2 fêmeas (INPA; identificado como C. distans Butler, A.M. Sakakibara det.); Benjamim Constant, XII.1960 (L.G. Pereira), 5 machos e 12 fêmeas (CACS); Benjamim Constant, I.1961 (L.G. Pereira), 27 machos e 49 fêmeas (CACS); Benjamim Constant, 13-14.I.1977 (Camargo \& M. Mazucato), 1 macho (FMRP); Humaitá, VIII.1980 (G.S. Andrade), 5 machos e 4 fêmeas (CACS); Maranhão: Imperatriz, 4.VII.1974 (Exc. Depto. Zool.), 1 macho e 1 fêmea (DZUP); Imperatriz, 9.VII.1974 (Exc. Depto. Zool.), 1 macho (DZUP); Acre: Cruzeiro do Sul, 330 m, II.1963 (M. Alvarenga), 41 machos, 32 fêmeas e 1 sem abdome
(MZUSP); Feijó, XII.1956 (W.C.A. Bokermann), 1 macho (UPR); Mato Grosso: Barra do Tapirapé, 14.XII.1964 (B. Malkin), 2 machos (MZUSP); Parque Nacional do Xingu, Jacaré, XI.1961 (Alvarenga \& Werner), 1 macho (DZUP); Parque Nacional do Xingu, Jacaré, 15-30.II.1965 (M. Alvarenga), 1 fêmea (DZUP); Rosário Oeste, XI.1963 (sem coletor), 1 macho e 1 fêmea (MZUSP); Chapada dos Guimarães, IV.1963 (Machado), 1 macho e 1 fêmea (MN); Chapada dos Guimarães, "malaise", 2729.XI.1983 (Exc. Dep. Zool. UFPR, Polonoroeste), 1 macho (DZUP); Rondônia: Porto Velho, 8.II.1979 (D. Need), 1 macho (INPA; identificado como C. distans Butler, A.M. Sakakibara det.); Porto Velho, 16.II.1979 (J. Campbell), 1 macho e 1 fêmea (INPA); Porto Velho, 15.III.1979 (D. Need), 1 fêmea (INPA); Porto Velho, 21.III.1979 (D. Need), 1 fêmea (INPA); Porto Velho, 2.IV.1979 (J. Campbell), 1 fêmea (INPA); Forte Príncipe da Beira, 19.xi-3.XII.1967 (G.R. Kloss), 1 fêmea (MZUSP); Vilhena, 3.X.1986 (C. Elias, Polonoroeste), 1 fêmea (DZUP); sem indicação de localidade, 11.IX.1963 (Eduardo), 1 macho (INPA; identificado como C. distans Butler, A.M. Sakakibara det.); Goiás: Goiás, cor. Paciência, 7.VII.1984 (A. Raw), 1 fêmea (DZUP); Goiás, "gold creek", 10.VII.1984 (A. Raw), 1 fêmea (DZUP); Anápolis, 18.V.1938 (F. Lane), 1 fêmea (MZUSP); Jataí, XI.1971 (F.M. Oliveira), 1 fêmea (DZUP); Jataí, XI.1972 (F.M. Oliveira), 2 machos (DZUP); Minas Gerais: Pouso Alegre, 24-25.VI.1965 (Vulcano \& Pereira), 33 machos e 25 fêmeas (MZUSP); Mato Grosso do Sul: Rio Verde, II.1959 (sem coletor), 1 macho (CACS); Corumbá, 600 m, 20-22.IV.1985 (V.O. Becker), 1 macho (DZUP); Salobra, III.1940 (Com. Inst. O. Cruz), 1 macho (FIOC); Espírito Santo: Afonso Cláudio, 14.VII.1966 (C.T. \& C. Elias), 1 fêmea (DZUP); São Paulo: São Paulo, Parque Jabaquara, IX.1931 (sem coletor), 1 sem abdome (MZUSP); Itararé, 1924 (sem coletor), 1 fêmea (MZUSP). EqUADOR, Napo: Coca, V.1965 (L.E. Peña), 1 macho (UPR); Tena, 18.II.1983 (L. Huggert), 1 macho (LU). Peru, Loreto: Iquitos, III.1970 (R. Garcia), 1 fêmea (MHNJP); W de Iquitos, 4.II.1984 (L. Huggert), 1 macho e 3 fêmeas (LU); Ucayali: Pucallpa, 2.XI.1946 (J. Schunke), 1 macho (MHNJP); Pucallpa, sem data (J. Schunke), 1 fêmea (MHNJP); Pucallpa, Neshuya, 16.XII.1970 (R. Garcia), 2 machos e 3 fêmeas (MHNJP); Pucallpa, Neshuya, 250 m, 16.XII.1970 (R. Garcia), 2 machos (MHNJP); Pucallpa, km 34, 12.I.1974 (R. Garcia), 1 macho e 1 fêmea (MHNJP); rio Ucayali, Atalaya, 26.I.1972 (M. Baitrón), 1 fêmea (MHNJP); Huánuco: Tingo Maria, IV.1963 (L.E. Peña), 1 macho (UPR); rio Pachitea, Iparia, 320 m, 1.XII.1967 (R. Garcia), 2 fêmeas (MHNJP); rio Pachitea, Iparia, 320 m, 11.II.1968 (R. Garcia), 1 fêmea (MHNJP); Pasco: rio Pichis, Puerto Bermúdez, 12 19.VII.1920 (sem coletor), 1 macho (CU; identificado como C. sallei Stål, W.D. Funkhouser det.); Castilla, 350 m, em "kudzu" (Pueraria phaseoloides), 31.X.1986 (P. Lozada), 2 machos e 5 fêmeas (MHNJP); Iscozacín, 250 m, 12.VIII.1987 (P. Lozada), 2 fêmeas (MHNJP); Iscozacín, 250 m, 13.VIII.1987 (P. Lozada), 1 fêmea (MHNJP); San Juan de Cacazú, 830 m, 31.VIII.1987 (P. Lozada), 1 macho (MHNJP); Madre de Dios: Puerto Maldonado, 4.I.1984 (L. Huggert), 3 machos e 2 fêmeas (LU); Puerto

Revista Brasileira de Zoologia 21 (4): 671-738, dezembro 2004 
Maldonado, 8.I.1984 (L. Huggert), 1 macho e 2 fêmeas (LU); Tambopata, Albergue, 15.III.1987 (P. Lozada), 1 fêmea (MHNJP); Junín: Perené, El Campamiento, 18.VI.1920 (Cornell Univ. Exp.), 2 machos e 1 fêmea (CU; identificado como C. brunnicornis (Germar), W.D. Funkhouser det.); Perené, 21-23.VI.1920 (Cornell Univ. Exp.), 1 sem abdome (CU; identificado como $C$. brunnicornis (Germar), W.D. Funkhouser det.); Satipo, 29.IX.1940 (P. Paprzyck), 1 fêmea (FIOC); Satipo, 20.I.1984 (L. Huggert), 2 machos e 4 fêmeas (LU); Satipo, Pte. Miranda, 23.I.1984 (L. Huggert), 1 fêmea (LU); Valle Chanchamayo, 800 m, VIII.1941 (Weyrauch), 1 macho (FML; holótipo de C. peruensis RemesLenicov); Chanchamayo, 23.VI.1968 (Picho), 1 macho e 1 fêmea (UPR); Cuzco: Quillabamba, 23.XII.1983 (L. Huggert), 2 machos e 1 fêmea (LU). Bolívia, Cochabamba: Chapare, Villa Tunari, 500 m, 5-9.I.1958 (Monrós \& Wygodzinsky), 1 fêmea (FML); Ichilo, Buenavista, I.1950 (A. Martinez), 2 machos e 1 fêmea (MZUSP); Ichilo, Buenavista, II.1950 (A. Martinez), 2 machos e 1 fêmea (MZUSP).

Distribuição geográfica. ColômBia: Cundinamarca e Meta. Suriname: Saramacca e Marowijne. Brasil: Amazonas (Remes-Lenicov 1973), Pará (Butler 1877), Maranhão, Acre, Mato Grosso, Rondônia, Goiás, Minas Gerais, Mato Grosso do Sul, Espírito Santo e São Paulo. Equador: Napo. Peru: Huánuco e Junín (Remes-Lenicov 1973), Loreto, Ucayali, Pasco, Madre de Dios e Cuzco. Bolívia: La Paz e Santa Cruz (Remes-Lenicov 1973) e Cochabamba.

Localidade-tipo. Brasil, Pará.

Notas sobre os tipos. O holótipo sem abdome está depositado no BMNH, em razoável estado de conservação, microalfinetado em cartão, com o pronoto e protórax um pouco deslocado e superficialmente empoeirado. Faltam tarso I esquerdo, coxa, trocânter, fêmur, tíbia e tarso II esquerdos, parte da coxa, trocânter, fêmur, tíbia e tarso III esquerdos, tarso I direito, tíbia e tarso II direitos e trocânter, fêmur, tíbia e tarso III direitos. Parte da coxa III está perfurada pelo alfinete.

Planta hospedeira. "kudzu", Pueraria phaseoloides (observação de P. Lozada).

Comentários. FunkHouser (1927b) colocou esta espécie na sinonímia de C. vitulus (Fabricius, 1775). O estudo comparativo do holótipo (sem abdome) de C. distans, depositado no $\mathrm{BMNH}$, com o lectótipo macho de C. vitulus, depositado no $\mathrm{ZM}$, mostrou que se tratam de espécies distintas, confirmando as observações de Remes-Lenicov (1973).

O mesmo procedimento com o holótipo macho de $C$. peruensis mostrou que se tratam da mesma espécie.

Foram observadas variações na coloração, principalmente na região ventral do corpo, na extensão e inclinação dos processos supra-umerais e no grau de extensão do ápice do pronoto com relação a altura da base da $3^{\text {a }}$ célula apical das tégminas, bem como no grau de constrição, esclerotinização e conformação da metade distal dos parâmeros.

Esta espécie é muito semelhante a $C$. cuprea Funkhouser. Difere notadamente por não apresentar a aresta $M$ na metade distal dos processos supra-umerais.

\section{Ceresa ustulata Fairmaire, 1846 Figs 65-71}

Ceresa ustulata Fairmaire, 1846: 285; Metcalf \& Wade, 1965: 867 (cat.); Remes-Lenicov, 1973: 109, lám. XXI, figs 150 a 158 (gen. masc. fem.), 108 e 121 (not.); Kopp \& Yonke, 1979: 24, figs 279 a 283 (list.); Andrade, 1989: 143 (not.); McKamey, 1998: 246 (cat.).

Ceresa plana Walker, 1851: 529; Metcalf \& Wade, 1965: 865 (cat., = C. ustulata Fairmaire, 1846); Broomfield, 1971: 369 (tip.); McKamey, 1998: 246 (cat., = C. ustulata Fairmaire, 1846).

Ceresa insignis Walker, 1858: 67. syn. nov.

Ceresa insignis; Metcalf \& Wade, 1965: 863 (cat.); Broomfield, 1971: 356 (tip.); Kopp \& Yonke, 1979: 24 (list.); McKamey, 1998: 245 (cat.).

Centrogonia speciosa Goding, 1930: 18; Metcalf \& Wade, 1965: 830 (cat.); Kopp \& Yonke, 1979: 24 (sin., = C. ustulata Fairmaire, 1846); McKamey, 1998: 246 (cat., = C. ustulata Fairmaire, 1846).

Medidas. Macho/fêmea. Largura da cabeça: 2,48/2,60; comprimento da cabeça: 1,24/1,30; distância entre os ângulos umerais: 2,48/2,60; distância entre os ápices dos processos supra-umerais: 4,68/4,60; comprimento do pronoto: $6,00 / 6,25$; comprimento total: 6,58/7,00.

Descrição. Macho. Coloração geral amarelada. Porção distal da face dorsal, face ventral e face posterior dos processos supra-umerais, regiões supra-umerais e região posterior do pronoto, amarronzadas; aresta $\mathrm{M}$ amarelada na metade basal; lóbulos pós-oculares acastanhados; ápices dos processos supraumerais e do pronoto negros. Tégminas hialinas, com o bordo costal acastanhado e uma mácula amarronzada ao nível das $1^{a}$, $2^{\mathrm{a}}$ e $3^{\mathrm{a}}$ células apicais; veias amareladas, mais escurecidas no terço distal. Região ventral do corpo amarelada, com as pleuras torácicas acastanhadas. Pernas amareladas, com as coxas e fêmures, notadamente os posteriores, acastanhados.

Cabeça com a superfície fortemente estriada, com algumas pontuações, corrugada no frontoclípeo e nos lóbulos supra-antenais. Sutura coronal atingindo a base do frontoclípeo. Espaço interocelar plano, espaços ocelo-oculares planos. Lóbulos supra-antenais planos, com as margens sinuosas. Frontoclípeo sublosângico, metade distal com os bordos laterais chanfrados e dirigida para baixo.

Pronoto com pontuação homogênea, não abaulado nas regiões adjacentes às impressões semicirculares, fracamente elevado atrás do espaço entre os processos supra-umerais, levemente em declive e afilado para o ápice após o ponto mais elevado e não constricto ao nível do ângulo interno das tégminas. Metopídio trapezoidal, com as impressões musculares em forma de L invertido. Lóbulos pós-oculares com a superfície corrugada, sem modificações ao nível do ângulo externo dos olhos. Sulcos supra-umerais bem marcados, regiões supra-umerais com a superfície pontuada. Processos supra-umerais 
desenvolvidos, prismáticos, curvos na metade distal, dirigidos para os lados, inclinados para cima e com os ápices voltados para os lados e para trás; face dorsal escavada, face posterior pontuada; espaço entre eles convexo; arestas A e P cortantes na metade distal; aresta $\mathrm{M}$ pronunciada em toda a sua extensão; espaços anterior e posterior a aresta $M$ escavados. Impressões semicirculares pouco distintas, áreas semicirculares planas e um pouco impressas. Carena dorsal cortante a partir do ponto mais elevado do pronoto. Ápice atingindo a altura da base da $3^{\text {a }}$ célula apical das tégminas.

Tégminas com a veia $\mathrm{R} 1$ originando-se na $1^{\mathrm{a}}$ célula discoidal.

Genitália. Edeago subcilíndrico, afilado distalmente, com o ápice um pouco dilatado; face dorsal com bandas laterais de dentículos escamiformes distribuídos em mosaico nos três quartos basais. Parâmeros achatados lateralmente na metade distal, curvados para cima e para dentro no terço distal, com uma carena longitudinal na face interna; ápice em forma de faca, mais esclerotinizado, com a carena mais proeminente; pilosidade curta distribuída na face interna da metade distal, dirigida para o bordo superior. Placas laterais do pigóforo com o dente apical intumescido, situado no ângulo central; dente lateral bem desenvolvido, localizado no terço mediano, diagonalmente dirigido para baixo e com o ápice mamilar. Placa subgenital piriforme, quase duas vezes mais longa que larga medianamente.

Fêmea. Semelhante ao macho, apenas um pouco maior. Material examinado. BRAsIL, Bahia: Itaparica, X.1986 (J.S. Moure), 1 macho (DZUP); Goiás: Jataí, XI.1972 (F.M. Oliveira), 2 machos e 1 fêmea (DZUP); Minas Gerais: Lassance, 9-19.XI.1919 (R.G. Harris, Cornell Univ. Exp.), 1 fêmea (CU); Passos, 2331.I.1963 (C. Elias), 1 fêmea (DZUP); Viçosa, 30.XI.1974 (P.S.F. Ferreira), 2 machos, 4 fêmeas e 1 sem abdome (UFV); Mato Grosso do Sul: Aquidauana, 11-13.XII.1919 (Cornell Univ. Exp.), 1 fêmea (CU); Rio Brilhante, à luz, 25.I.1971 (V.O. Becker), 13 machos e 9 fêmeas (DZUP); Espírito Santo: Conceição da Barra, Pedro Canário, X.1972 (M. Alvarenga), 1 macho e 2 fêmeas (DZUP); Córrego do Itá, XII.1981 (B. Silva), 1 fêmea (CACS); Linhares, IX.1971 (F.M. Oliveira), 7 fêmeas (DZUP); Linhares, IX.1972 (M. Alvarenga), 5 machos e 5 fêmeas (DZUP); Colatina, XII.1969 (F.M. Oliveira), 2 fêmeas (DZUP); Santa Teresa, 13.I.1966 (C.T. \& C. Elias), 1 fêmea (DZUP); Santa Teresa, 5.IV.1967 (C.T. \& C. Elias), 1 macho (DZUP); Santa Teresa, 26.VI.1967 (C.T. \& C. Elias), 1 fêmea (DZUP); São Paulo: Bauru, 4.XII.1919 (Cornell Univ. Exp.), 4 machos e 1 fêmea (CU); Piracicaba, ESALQ, 16.III.1965 (S. Silveira Neto), 1 fêmea (ESALQ); Piracicaba, ESALQ, 540 m, "ligth trap", 13.XII.1965 (Neto \& Wiendl), 1 fêmea (ESALQ); Piracicaba, IX.1966 (Belluzzo N.), 1 fêmea (ESALQ); Barueri, 29.V.1966 (K. Lenko), 1 fêmea (MZUSP); Rio de Janeiro: Niterói, 15.X.1919 (Cornell Univ. Exp.), 1 fêmea (CU); Rio de Janeiro, represa Rio Grande, IX.1972 (F.M. Oliveira), 2 fêmeas (DZUP); Paraná: Maringá, V.1961 (S. Laroca), 1 fêmea (DZUP; comparado com os lectótipos de C. plana Walker e C. insignis Walker); Juçara, H. Florestal, 340 m, 1-3.XI.1974 (Exp. Depto.
Zool. UFPR), 2 machos e 1 fêmea (DZUP); Campo Mourão, 15.IX.1968 (J.S. Moure), 1 fêmea (DZUP); Santa Catarina: Florianópolis, Naufragados, 12.X.1986 (B.C. Lopes), 1 fêmea (BCL); Florianópolis, morro da Lagoa, em Vernonia polyanthes, 16.X.1986 (B.C. Lopes), 1 fêmea (BCL); Rio Grande do Sul: Santo Augusto, XII.1975 (O. Roppa), 1 macho e 3 fêmeas (DZUP); Porto Alegre, III.1941 (J.P. Costa Neto), 1 fêmea (UPR). ParaguaI, Caaguazú: Estancia Primera, 1.XII.1931 (R.F. Hussey), 1 fêmea (UPR); Sem indicação de Departamento: Pirapo, 2.I.1972 (L.E. Peña), 1 fêmea (UPR); Pastoreo, 5.I.1972 (L.E. Peña), 1 fêmea (UPR); sem indicação de localidade, 1985 (R. Barragán), 1 macho (DZUP). Argentina, Jujuy: San Juancito, 27.II.1920 (Cornell Univ. Exp.), 1 fêmea (CU); Salta: Orán, II.1967 (Golbach), 1 macho (FML); Pocitos, XII.1971 (M.A. Fritz), 1 fêmea (DZUP); Corrientes: Paso de los Libres, 12-14.I.1920 (Cornell Univ. Exp.), 2 fêmeas (CU); sem indicação de localidade, sem data (sem coletor), 1 fêmea (FCNM; "Cum typo comparat").

Distribuição geográfica. Brasil: Minas Gerais (Remes-Lenicov 1973), Bahia, Goiás, Mato Grosso do Sul, Espírito Santo, São Paulo, Rio de Janeiro, Paraná, Santa Catarina e Rio Grande do Sul. Paraguai: Caaguazú. Argentina: Misiones e Corrientes (Berg 1879), Jujuy, Salta, Formosa, Chaco, Tucumán, Santa Fe e Córdoba (ReMES-LENICOV 1973).

Localidade-tipo. "Brésil..." (Fairmaire 1846). Embora não seja possível precisar mais esta indicação, as localidades-tipo das espécies incluídas na sinonímia de C. ustulata podem ser definidas com maior acuracidade.

Na descrição original de C. plana Walker foi feita a vaga indicação "Brazil", porém segundo BRoOMFIELD (1971) existe uma etiqueta “...'Rio; $45 ; 56$. ..." apensa ao alfinete do lectótipo macho desta espécie, o que sugere que o exemplar seja oriundo, ao menos, do estado do Rio de Janeiro. É possível que os números constantes na etiqueta sejam referentes a algum registro existente no $\mathrm{BMNH}$ e possam precisar a localidade-tipo desta espécie.

C. insignis Walker é citada no catálogo de MetCalf \& WADE (1965) como de ocorrência em “...1 Veracruz. ${ }^{2}$ Mexico.". BRoOMFIELD (1971) não faz referência a nenhuma etiqueta de procedência pertinente ao lectótipo fêmea desta espécie, mas a descrição original indica claramente "Vera Cruz" como local de procedência do material examinado, o qual provavelmente corresponde a algum dos topônimos Vera Cruz situados ao longo da Mata Atlântica. O exame da literatura mostrou que a associação “...Vera Cruz, Mex...” foi feita por Goding (1893) e mantida pelos autores subseqüentes.

A localidade-tipo de Centrogonia speciosa Goding não foi precisada na descrição original, mas o material examinado informado pelo autor indica que seja Rio Grande do Sul, Rio de Janeiro ou Corumbá.

Todas estas localidades estão dentro da área de dispersão até então conhecida para C. ustulata, cujo limite setentrional de distribuição se encontra na altura do paralelo $12^{\circ}$ de latitude sul.

Revista Brasileira de Zoologia 21 (4): 671-738, dezembro 2004 
Notas sobre o(s) tipo(s). Segundo a descrição original esta espécie foi descrita com base em material da coleção M. Spinola, atualmente depositada no MRSN. Dentre os exemplares obtidos para estudo junto à esta instituição encontrou-se um, fêmea, que se ajusta bem à descrição original e à interpretação dos autores para esta espécie. Porém, segundo Casale (1981), os dados costantes na etiqueta de caixa pertinente ao exemplar são "Ceresa maculipennis Spinola, Brasilia e Buquet". Consulta aos trabalhos disponíveis de M. Spinola e ao catálogo de Metcalf \& WADE (1965) mostrou que este binômio não foi publicado. Embora uma etiqueta adicional apensa ao alfinete do exemplar por A. Casale traga a informação "syntyp.", C. maculipennis Spinola deve ser considerado como nomen manuscriptum.

Devido a estas circunstâncias preferimos não designar o referido exemplar como lectótipo de C. ustulata.

Plantas hospedeiras. Vernonia polyanthes (observação de B.C. Lopes), Eupatorium sp., Vernonia sp., Batura sp. e Mimosa bimucronata (informações de C.F. Varella) e "fedegoso", Senna obtusifolia (informação de C.A.D. Teixeira).

Comentários. Esta espécie foi interpretada com base na descrição original, na descrição e ilustrações de REMEs-LeNICOV (1973) e em um exemplar fêmea pertencente a coleção C. Berg, depositado na FCNM, o qual porta uma etiqueta com os dizeres "Cum typo comparat".

STÅL (1869b) colocou C. plana Walker na sinonímia desta espécie e no presente estudo consideramos $C$. insignis Walker também idêntica a C. ustulata. Respondendo ao envio de material ao BMNH para comparação com o lectótipo fêmea de $C$. insignis, P.S. Broomfield (comunicação pessoal) informou: "Ceresa insignis Walker; your determination is correct. This species is a synonym of $C$. plana Walker, but whether synonymous with C. ustulus Fairmair (sic) I cannot say, not having seen the type of the latter.".

Centrogonia speciosa Goding foi incluida na sinonímia desta espécie por Kopp \& Yonke (1979), sem nenhuma argumentação. O estudo comparativo do material interpretado no presente estudo como C. ustulata com um diapositivo de um dos tipos de Centrogonia speciosa depositado no NMNH, confirmou que se tratam da mesma espécie.

Foram observadas variações no aspecto da face dorsal dos processos supra-umerais e do espaço entre eles, e na aparência dos sulcos supra-umerais.

Difere das demais espécies notadamente pelo padrão de coloração.

\section{Ceresa projecta Funkhouser, 1927 sp. rev. Figs 72-78}

Ceresa projecta Funkhouser, 1927: 161, pl. XVII, fig. 4. sp. rev. Ceresa projecta; Metcalf \& Wade, 1965: 865 (cat.); Remes-Lenicov, 1973: 102, lám. XVIII, figs 128 a 136 (gen. masc. fem.); Kopp \& Yonke, 1974: 137 (rep. tip.); Kopp \& Yonke, 1979: 23 (sin., = C. cavicornis Stål, 1859); McKamey, 1998: 244 (cat., = C. cavicornis Stål, 1859).
Medidas. Macho/fêmea. Largura da cabeça: 2,36/2,48; comprimento da cabeça: 1,00/1,12; distância entre os ângulos umerais: 2,32/2,56; distância entre os ápices dos processos supra-umerais: $3,40 / 3,96$; comprimento do pronoto: 6,17/6,50; comprimento total: 7,17/7,17.

Descrição. Macho. Coloração geral ferruginosa, escurecida no fundo das pontuações. Porção apical da face dorsal e face ventral dos processos supra-umerais, e lóbulos pós-oculares, acastanhadas; aresta $\mathrm{M}$ amarelada; ápice do pronoto negro. Tégminas hialinas, com uma mácula acastanhada ao nível das $1^{\text {a }}$ e $2^{\mathrm{a}}$ células apicais; veias ferruginosas, mais escurecidas no terço distal. Região ventral do corpo e pernas ferruginosas.

Cabeça com a superfície fortemente estriada, com algumas pontuações, corrugada no frontoclípeo e nos lóbulos supra-antenais. Sutura coronal atingindo a base do frontoclípeo, mais marcada junto a margem superior. Espaço interocelar convexo, espaços ocelo-oculares deprimidos. Lóbulos supraantenais escavados, com as margens sinuosas. Frontoclípeo sublosângico, metade distal com os bordos laterais chanfrados e dirigida fortemente para trás.

Pronoto com pontuação homogênea, não abaulado nas regiões adjacentes às impressões semicirculares, fracamente elevado atrás do espaço entre os processos supra-umerais, levemente em declive e afilado para o ápice após o ponto mais elevado e não constricto ao nível do ângulo interno das tégminas. Metopídio trapezoidal, com as impressões musculares em forma de L invertido. Lóbulos pós-oculares com a superfície corrugada, sem modificações ao nível do ângulo externo dos olhos. Sulcos supra-umerais pouco marcados, regiões supraumerais com a superfície pontuada. Processos supra-umerais desenvolvidos, prismáticos, retos na metade distal, dirigidos para os lados, inclinados para cima e com os ápices voltados para os lados e para trás; face dorsal plana, face posterior pontuada; espaço entre eles plano; arestas A e P cortantes na metade distal; aresta $\mathrm{M}$ pronunciada em toda a sua extensão; espaços anterior e posterior a aresta $\mathrm{M}$ escavados. Impressões semicirculares pouco distintas, áreas semicirculares planas e bem impressas. Carena dorsal cortante a partir do ponto mais elevado do pronoto. Ápice atingindo a altura da base da $3^{\mathrm{a}}$ célula apical das tégminas.

Tégminas com a veia $\mathrm{R} 1$ originando-se na $1^{\mathrm{a}}$ célula discoidal.

Genitália. Edeago subcilíndrico, com o ápice um pouco dilatado; face dorsal com dentículos escamiformes distribuídos em mosaico na metade basal. Parâmeros um pouco achatados lateralmente, curvados para cima e para dentro no terço distal; ápice em forma de faca, mais esclerotinizado, com a margem do bordo inferior mais cortante; pilosidade curta distribuída na face interna do terço distal, mais abundante junto ao bordo inferior. Placas laterais do pigóforo com o dente apical intumescido, situado no ângulo central; dente lateral bem desenvolvido, localizado no terço mediano, diagonalmente dirigido para baixo, com o ápice afilado e curvado também para baixo. Placa subgenital subtriangular, duas vezes mais longa que larga basalmente. 


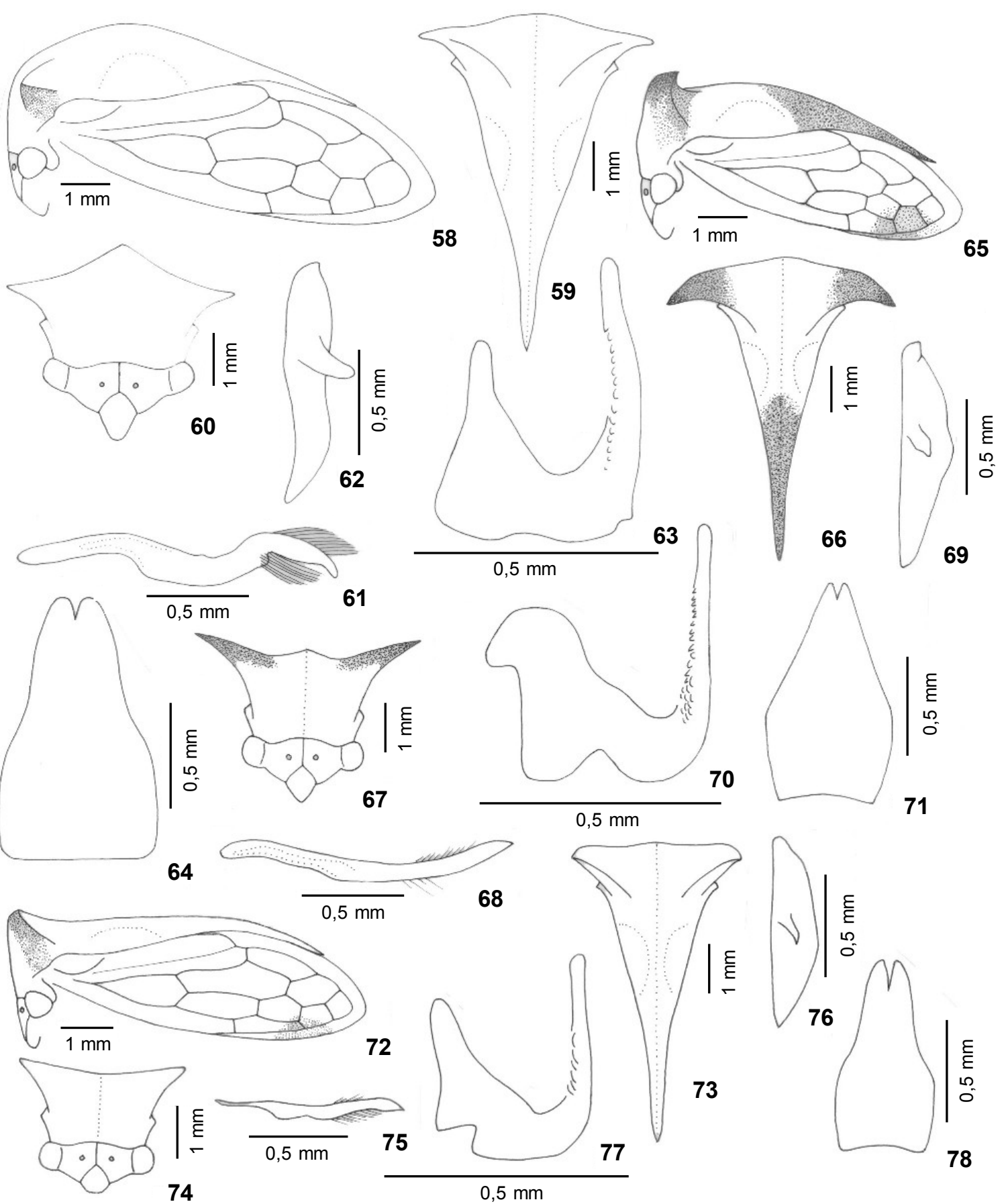

Figuras 58-78. (58-64) Ceresa distans: (58) cabeça, pronoto e tégmina, vista lateral; (59) pronoto, vista dorsal; (60) cabeça e pronoto, vista frontal; (61) parâmero esquerdo, vista lateral; (62) placa lateral esquerda do pigóforo, vista lateral; (63) edeago, vista lateral; (64) placa subgenital, vista ventral; (65-71) Ceresa ustulata: (65) cabeça, pronoto e tégmina, vista lateral; (66) pronoto, vista dorsal; (67) cabeça e pronoto, vista frontal; (68) parâmero esquerdo, vista lateral; (69) placa lateral esquerda do pigóforo, vista lateral; (70) edeago, vista lateral; (71) placa subgenital, vista ventral; (72-78) Ceresa projecta: (72) cabeça, pronoto e tégmina, vista lateral; (73) pronoto, vista dorsal; (74) cabeça e pronoto, vista frontal; (75) parâmero esquerdo, vista lateral; (76) placa lateral esquerda do pigóforo, vista lateral; (77) edeago, vista lateral; (78) placa subgenital, vista ventral. 
Fêmea. Semelhante ao macho, apenas um pouco maior. Material examinado. Argentina, Tucumán: Siambón, XI.1945 (Olea), 1 fêmea (FML); Córdoba: Cabana, 1.III.1959 (M. Birabén), 1 macho (FCNM); Calamuchita, El Sauce, II.1942 (M.J. Viana), 1 fêmea (FCNM); Marcos Juarez, 30.I.1981 (Bordón), 1 fêmea (CB; comparado com o holótipo).

Distribuição geográfica. Argentina: Córdoba (FunkHouser 1927a), Jujuy, Salta e Tucumán (Remes-Lenicov 1973).

Localidade-tipo. “...Cosquin, Sierra de Cordoba, Argentina,..." (FunKhouser 1927a).

Notas sobre o tipo. O holótipo fêmea está depositado na CU. O exame de fotografias do exemplar mostrou que se encontra em bom estado de conservação, alfinetado e com o abdome não dissecado.

Planta hospedeira. Desconhecida.

Comentários. Esta espécie foi interpretada com base na descrição e ilustração originais, na descrição e ilustrações de Remes-Lenicov (1973) e em um exemplar comparado o holótipo.

Kopp \& Yonke (1979) colocaram esta espécie na sinonímia de C. cavicornis Stål, 1859. O estudo comparativo do material interpretado no presente estudo como C. projecta e C. cavicornis mostrou que se tratam de espécies distintas.

Foram observadas variações na inclinação dos processos supra-umerais e no grau de extensão do ápice do pronoto com relação a altura da base da $3^{\mathrm{a}}$ célula apical das tégminas.

Esta espécie é semelhante a C. ustulata Fairmaire. Difere notadamente pelo padrão de coloração, por apresentar o pronoto menos elevado e, também das demais espécies, pela conformação da metade distal do frontoclípeo, fortemente dirigida para trás, o que resulta num aspecto subpentagonal desta estrutura, em vista anterior.

\section{Ceresa platycera Remes-Lenicov, 1973 Figs 79-85}

Ceresa platycera Remes-Lenicov, 1973: 106, lám. XX, figs 141 a 149; McKamey, 1998: 245 (cat.).

Medidas. Macho (holótipo)/fêmea (alótipo). Largura da cabeça: 2,28/2,56; comprimento da cabeça: 1,14/1,28; distância entre os ângulos umerais: 2,24/2,56; distância entre os ápices dos processos supra-umerais: $3,72 / 4,20$; comprimento do pronoto: 5,50/6,50; comprimento total: 6,33/7,00.

Descrição. Macho. Coloração geral amarelada. Face ventral e porção apical da face posterior dos processos supraumerais, regiões supra-umerais e metade distal da carena dorsal, acastanhadas; aresta $\mathrm{M}$ esbranquiçada na metade basal; ápices dos processos supra-umerais e do pronoto negros. Tégminas hialinas, acastanhadas na base; veias amareladas, mais escurecidas no terço distal. Região ventral do corpo amarelada, com as pleuras mesotorácicas acastanhadas. Pernas amareladas, com os fêmures posteriores acastanhados.

Cabeça com a superfície fortemente estriada, com algumas pontuações, corrugada no frontoclípeo e nos lóbulos su- pra-antenais. Sutura coronal atingindo a base do frontoclípeo. Espaço interocelar convexo, espaços ocelo-oculares planos. Lóbulos supra-antenais escavados, com as margens sinuosas. Frontoclípeo sublosângico, metade distal com os bordos laterais chanfrados e dirigida para baixo.

Pronoto com pontuação homogênea, não abaulado nas regiões adjacentes às impressões semicirculares, fracamente elevado atrás do espaço entre os processos supra-umerais, levemente em declive e afilado para o ápice após o ponto mais elevado e não constricto ao nível do ângulo interno das tégminas. Metopídio trapezoidal, com as impressões musculares em forma de L invertido. Lóbulos pós-oculares com a superfície corrugada, sem modificações ao nível do ângulo externo dos olhos. Sulcos supra-umerais pouco marcados, regiões supra-umerais com a superfície pontuada. Processos supraumerais desenvolvidos, prismáticos, curvos na metade distal, dirigidos para os lados, inclinados para cima e com os ápices voltados para os lados e para trás; face dorsal plana, face posterior pontuada; espaço entre eles convexo; arestas A e P cortantes na metade distal; aresta $\mathrm{M}$ pronunciada em toda a sua extensão; espaços anterior e posterior a aresta M escavados. Impressões semicirculares pouco distintas, áreas semicirculares planas e não impressas. Carena dorsal cortante a partir do ponto mais elevado do pronoto. Ápice atingindo a altura da $3^{\text {a }}$ célula apical das tégminas.

Tégminas com a veia $\mathrm{R} 1$ originando-se na $1^{\mathrm{a}}$ célula discoidal.

Genitália. Edeago achatado ântero-posteriormente na metade basal, subcilíndrico na metade distal, afilado distalmente e com o ápice um pouco dilatado; face dorsal com bandas laterais de dentículos escamiformes distribuídos em mosaico na metade basal. Parâmeros achatados lateralmente e curvados para cima e para dentro na metade distal; ápice em forma de espátula, pouco esclerotinizado, afilado distalmente e com a ponta dirigida para baixo; pilosidade escassa e heterogênea distribuída ao longo dos bordos superior e inferior e na face interna, ao nível do terço distal. Placas laterais do pigóforo com o dente apical pouco proeminente, situado no ângulo central; dente lateral bem desenvolvido, localizado no terço mediano, diagonalmente dirigido para baixo, com o ápice afilado e discretamente curvado também para baixo. Placa subgenital subtriangular, quase duas vezes mais longa que larga basalmente.

Fêmea. Semelhante ao macho, apenas um pouco maior. Material examinado. BRASIL, Tocantins: Santa Isabel do Morro, VI.1961 (M. Alvarenga), 3 machos e 1 fêmea (DZUP; holótipo macho, alótipo fêmea e parátipos); Santa Isabel do Morro, VI.1961 (M. Alvarenga), 1 macho e 1 fêmea (FCNM; parátipos); Mato Grosso: rio Culuene, 1948 (J.C.M. Carvalho), 1 macho e 2 fêmeas (DZUP).

Distribuição geográfica. BRAsil: Tocantins (RemEs-LenICOV 1973) e Mato Grosso.

Localidade-tipo. BRASIL, Tocantins: Santa Isabel do Morro. 
Notas sobre os tipos. O holótipo macho está depositado na DZUP, em razoável estado de conservação, alfinetado e com o abdome dissecado. Faltam a antena direita, tíbia e tarso III esquerdos, fêmur, tíbia e tarso I direitos, tarso II direito e perna III direita. O edeago, a placa lateral direita do pigóforo e a placa subgenital não se encontram no microtubo apenso ao alfinete. Segundo a descrição original, existem o alótipo fêmea, quatro parátipos machos e um parátipo fêmea também na DZUP. Cabe ressaltar que só foram localizados nesta instituição, além do holótipo, o alótipo e dois parátipos machos, e um casal de parátipos na FCNM. O repositório do outro parátipo macho é incógnito.

Planta hospedeira. Desconhecida.

Comentários. Esta espécie é semelhante a C. ustulata Fairmaire. Difere notadamente pelo padrão de coloração e por apresentar o pronoto mais elevado.

\section{Ceresa piramidalis Remes-Lenicov, 1973 Figs 86-92}

Ceresa piramidalis Remes-Lenicov, 1973: 122, lám. XXVI, figs 195 a 201; McKamey, 1998: 245 (cat.).

Medidas. Macho. Largura da cabeça: 2,76; comprimento da cabeça: 1,38; distância entre os ângulos umerais: 2,92; distância entre os ápices dos processos supra-umerais: 4,00; comprimento do pronoto: 6,83; comprimento total: 7,92.

Descrição. Macho. Coloração geral amarelada e uniforme. Ápice do pronoto negro. Tégminas e veias ambarinas, com uma mácula acastanhada ao nível das $1^{\mathrm{a}}$ e $2^{\mathrm{a}}$ células apicais. Região ventral do corpo e pernas amareladas.

Cabeça com a superfície estriada na base e nos espaços ocelo-oculares, lisa no espaço interocelar e corrugada nas demais regiões. Sutura coronal atingindo a base do frontoclípeo, mais marcada junto a margem superior. Espaço interocelar convexo, espaços ocelo-oculares planos. Lóbulos supra-antenais planos, com as margens arredondadas. Frontoclípeo sublosângico, metade distal com os bordos laterais inteiros e dirigida para baixo.

Pronoto com pontuação homogênea, não abaulado nas regiões adjacentes às impressões semicirculares, regularmente elevado atrás do espaço entre os processos supra-umerais, gradualmente em declive e afilado para o ápice após o ponto mais elevado e não constricto ao nível do ângulo interno das tégminas. Metopídio trapezoidal, com as impressões musculares em forma de L invertido. Lóbulos pós-oculares com a superfície corrugada, sem modificações ao nível do ângulo externo dos olhos. Sulcos supra-umerais pouco marcados, regiões supra-umerais com a superfície pontuada. Processos supraumerais desenvolvidos, prismáticos, retos na metade distal, dirigidos para os lados, inclinados para cima e com os ápices voltados para os lados; face dorsal plana, face posterior pontuada; espaço entre eles plano; arestas A e P aparentes na metade distal; aresta $\mathrm{M}$ pronunciada como um intumescimento em toda a sua extensão; espaços anterior e posterior a aresta $\mathrm{M}$ normais. Impressões semicirculares bem distintas, áreas semicirculares planas e não impressas. Carena dorsal cortante a partir do ponto mais elevado do pronoto. Ápice não atingindo a altura da base da $3^{\text {a }}$ célula apical das tégminas.

Tégminas com a veia $\mathrm{R} 1$ originando-se na $1^{\mathrm{a}}$ célula discoidal.

Genitália. Edeago achatado ântero-posteriormente, com o ápice um pouco curvado para trás; face dorsal com uma fileira dupla de dentículos de cada lado nos três quartos basais, divergentes entre si. Parâmeros achatados lateralmente na metade distal, curvados para cima e para dentro no terço distal, afilados distalmente e abruptamente alargados na porção apical; ápice em forma de leque, pouco esclerotinizado, com um ângulo agudo no bordo inferior; pilosidade longa e homogênea distribuída ao longo dos bordos superior e inferior, ao nível do terço distal. Placas laterais do pigóforo com o dente apical conspícuo, situado no ângulo central; dente lateral bem desenvolvido, localizado no terço mediano, curvado para baixo e para trás, com o ápice arredondado. Placa subgenital dilatada na região mediana, mais de duas vezes longa que larga basalmente. Fêmea. Desconhecida.

Material examinado. Brasil, Paraná: Foz do Iguaçu, 3.XII.1966 (Exc. Depto. Zool.), 1 macho (FCNM; holótipo).

Distribuição geográfica. Brasil: Paraná (Remes-Lenicov 1973).

Localidade-tipo. Brasil, Paraná: Foz do Iguaçu.

Notas sobre o tipo. Segundo a descrição original o holótipo macho estaria depositado na DZUP, mas foi localizado na FCNM. O exemplar está em mal estado de conservação, alfinetado e com o abdome dissecado, com a porção apical dos processos supra-umerais quebrada e a porção mediana do processo supra-umeral esquerdo rachada. Faltam trocânter, fêmur, tíbia e tarso II direitos.

Planta hospedeira. Desconhecida.

Comentários. Difere das demais espécies notadamente pela aparência brilhante do tegumento e pela conformação piramidal dos processos supra-umerais.

\section{Ceresa atrata Remes-Lenicov, 1973 Figs 93-99}

Ceresa atrata Remes-Lenicov, 1973: 124, lám. XXVII, figs 202 a 210; McKamey, 1998: 244 (cat.).

Medidas. Macho (holótipo)/fêmea (alótipo). Largura da cabeça: 2,56/2,44; comprimento da cabeça: .../1,22; distância entre os ângulos umerais: $2,76 / 2,56$; distância entre os ápices dos processos supra-umerais: 4,44/3,04; comprimento do pronoto: 6,17/4,33; comprimento total: 7,17/6,92.

Descrição. Macho. Coloração geral amarronzada, com máculas amareladas. Lóbulos supra-antenais com um ponto negro ao lado do frontoclípeo. Face ventral dos processos supra-umerais, regiões supra-umerais, lóbulos pós-oculares e re- 

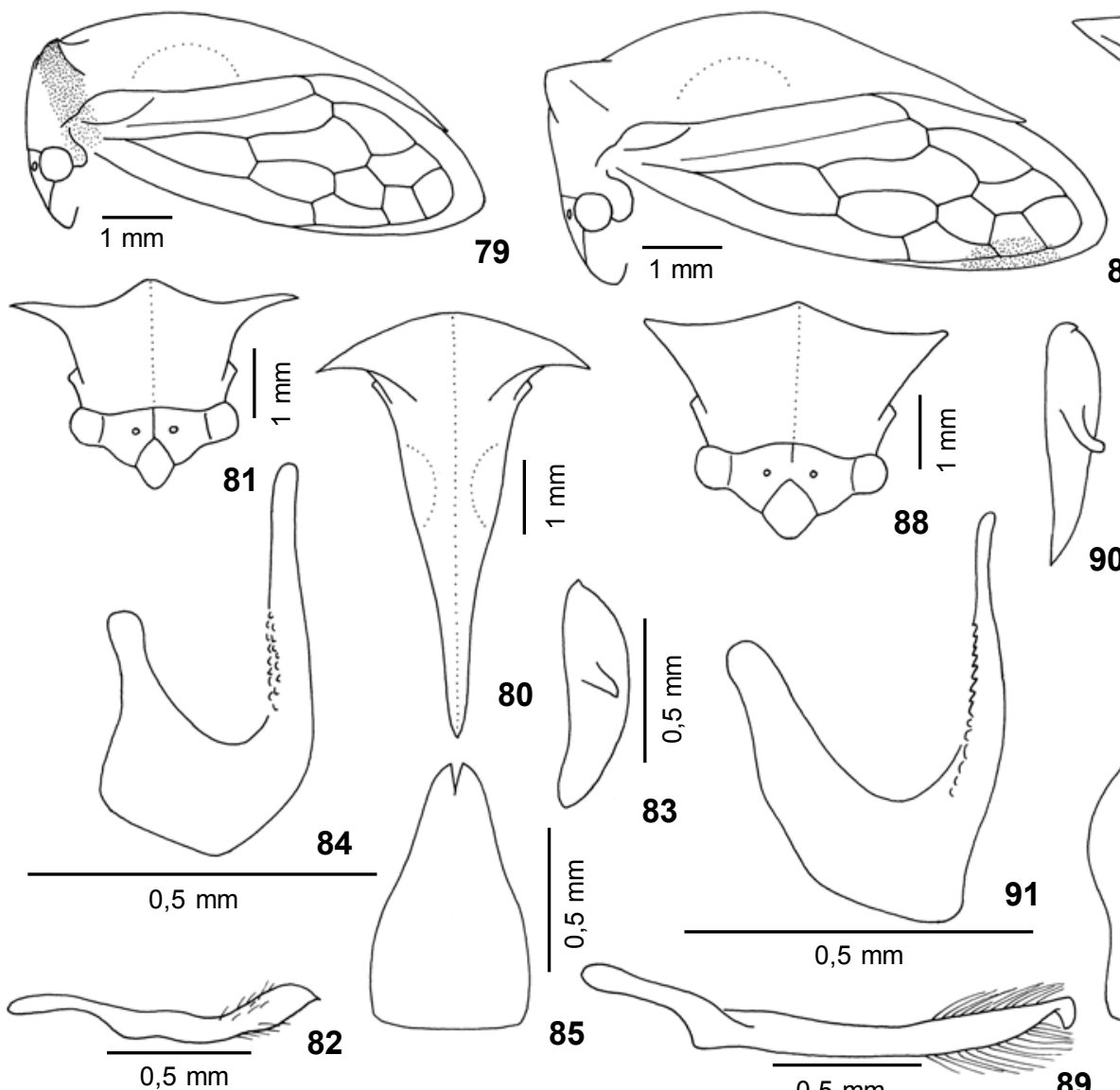

86
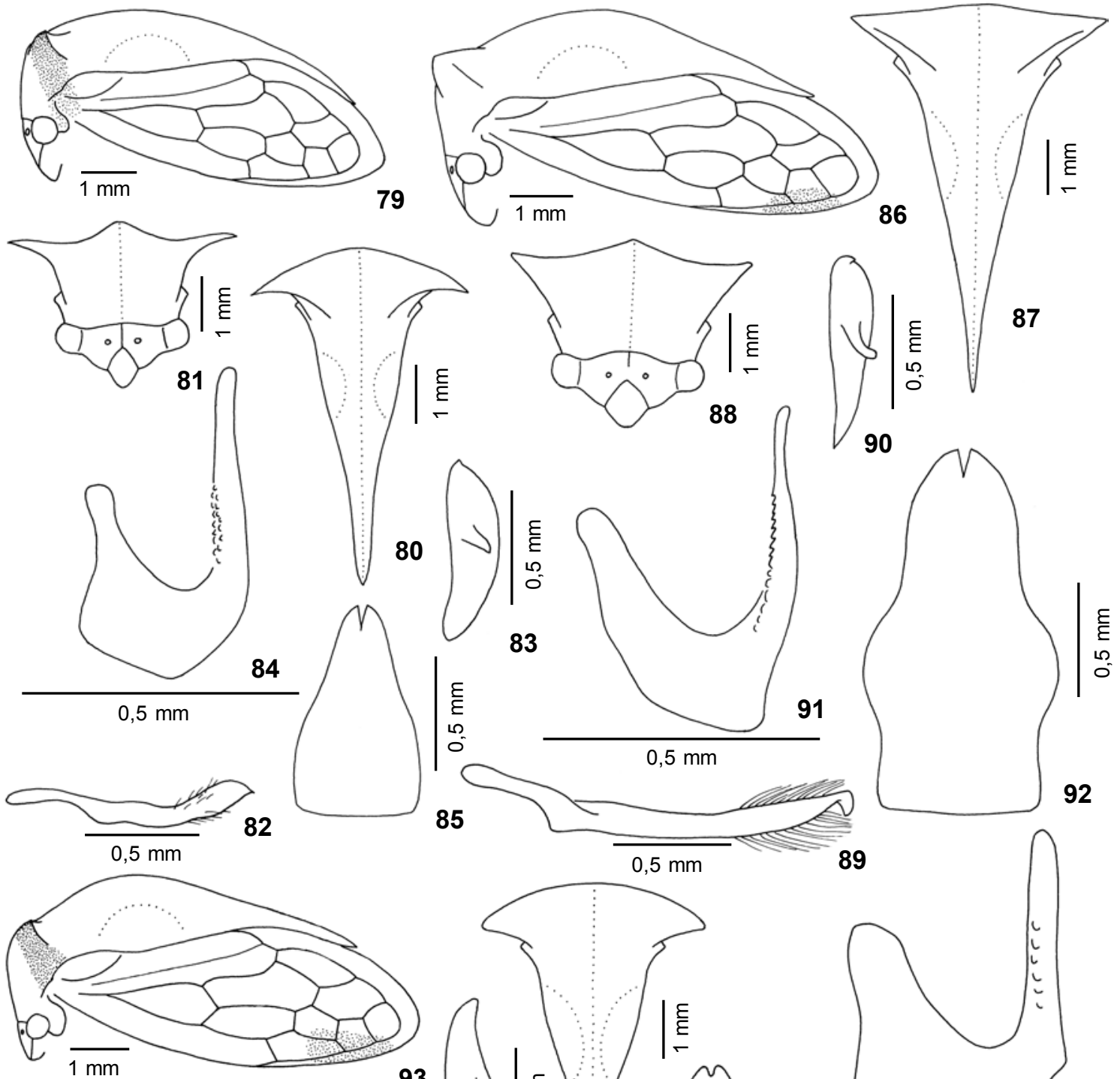

85
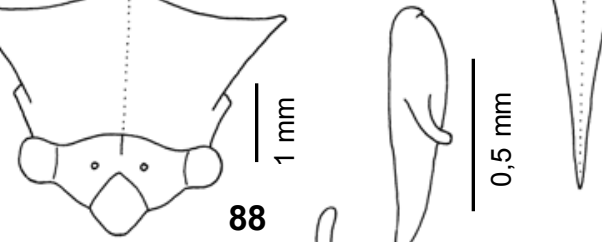

87
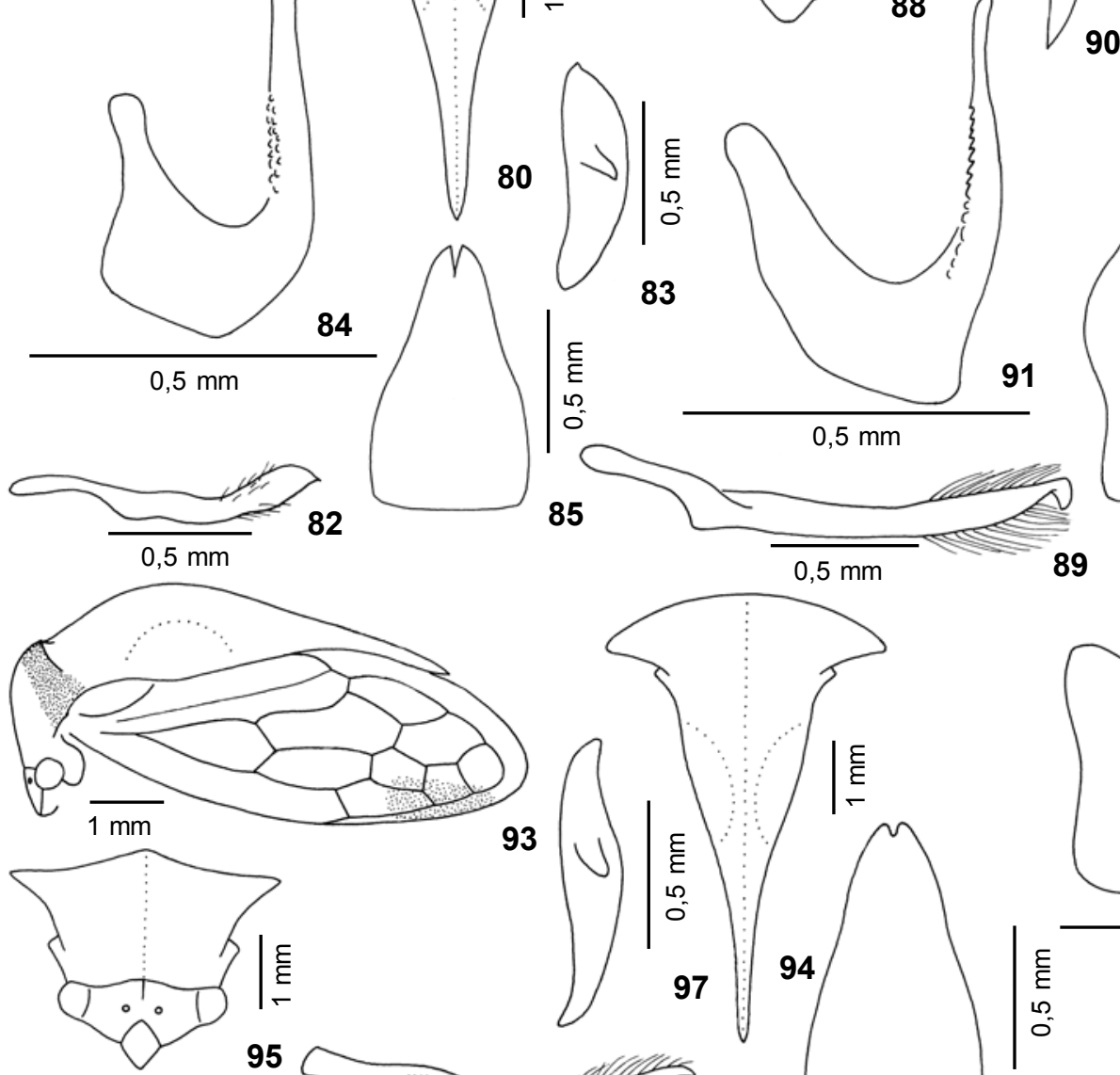

93

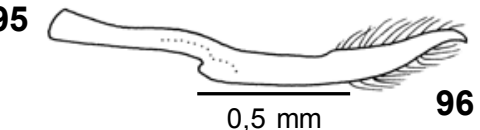

96

83
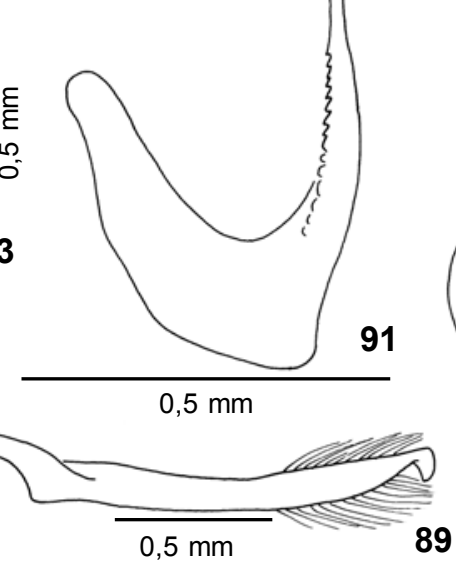

90

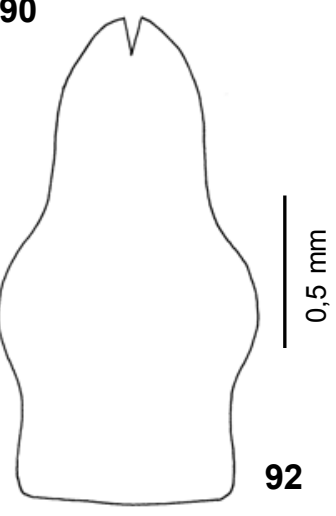

92

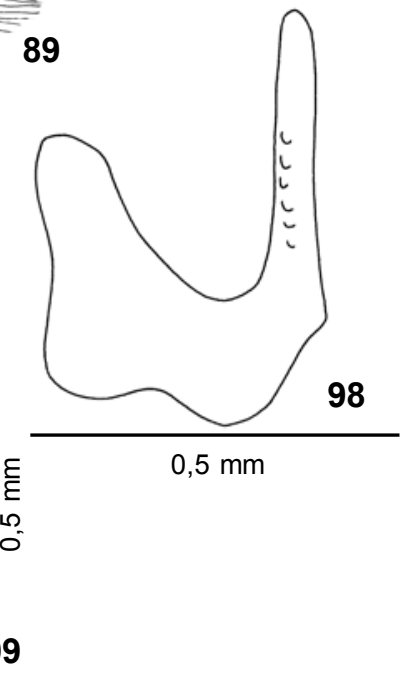

Figuras 79-99. (79-85) Ceresa platycera: (79) cabeça, pronoto e tégmina, vista lateral; (80) pronoto, vista dorsal; (81) cabeça e pronoto, vista frontal; (82) parâmero esquerdo, vista lateral; (83) placa lateral esquerda do pigóforo, vista lateral; (84) edeago, vista lateral; (85) placa subgenital, vista ventral; (86-92) Ceresa piramidalis: (86) cabeça, pronoto e tégmina, vista lateral; (87) pronoto, vista dorsal; (88) cabeça e pronoto, vista frontal; (89) parâmero esquerdo, vista lateral; (90) placa lateral esquerda do pigóforo, vista lateral; (91) edeago, vista lateral; (92) placa subgenital, vista ventral; (93-99) Ceresa atrata: (93) cabeça, pronoto e tégmina, vista lateral; (94) pronoto, vista dorsal; (95) cabeça e pronoto, vista frontal; (96) parâmero esquerdo, vista lateral; (97) placa lateral esquerda do pigóforo, vista lateral; (98) edeago, vista lateral; (99) placa subgenital, vista ventral.

Revista Brasileira de Zoologia 21 (4): 671-738, dezembro 2004 
gião posterior do pronoto, enegrecidas; aresta $\mathrm{M}$ amarelada na metade basal; porção distal dos processos supra-umerais e ápice do pronoto negros; carena dorsal entre o metopídio e o ponto mais elevado do pronoto e margens laterais do pronoto amareladas. Tégminas hialinas, com uma mácula acastanhada ao nível das $1^{\mathrm{a}}$ e $2^{\mathrm{a}}$ células apicais; veias ferruginosas. Região ventral da cabeça e pleuras torácicas negras; abdome ferruginoso. Pernas acastanhadas, com as coxas e fêmures negros.

Cabeça com a superfície estriada, com algumas pontuações, corrugada no frontoclípeo e nos lóbulos supra-antenais. Sutura coronal atingindo a base do frontoclípeo. Espaço interocelar convexo, espaços ocelo-oculares planos. Lóbulos supra-antenais planos, com as margens sinuosas. Frontoclípeo sublosângico, metade distal com os bordos laterais chanfrados e dirigida para baixo.

Pronoto com pontuação homogênea, não abaulado nas regiões adjacentes às impressões semicirculares, regularmente elevado atrás do espaço entre os processos supra-umerais, gradualmente em declive e afilado para o ápice após o ponto mais elevado e não constricto ao nível do ângulo interno das tégminas. Metopídio trapezoidal, com as impressões musculares em forma de L invertido. Lóbulos pós-oculares com a superfície pontuada, sem modificações ao nível do ângulo externo dos olhos. Sulcos supra-umerais bem marcados, regiões supraumerais com a superfície pontuada. Processos supra-umerais desenvolvidos, prismáticos, retos na metade distal, dirigidos para os lados, sem inclinação e com os ápices voltados para os lados; face dorsal plana, face posterior pontuada na metade basal e corrugada na metade distal; espaço entre eles plano; arestas A e $\mathrm{P}$ aparentes na metade distal; aresta $\mathrm{M}$ pronunciada na metade distal e apenas intumescida na metade basal; espaços anterior e posterior a aresta $\mathrm{M}$ normais. Impressões semicirculares pouco distintas, áreas semicirculares planas e bem impressas. Carena dorsal cortante a partir do ponto mais elevado do pronoto. Ápice não atingindo a altura da base da $3^{\mathrm{a}}$ célula apical das tégminas.

Tégminas com a veia $\mathrm{R} 1$ originando-se na $1^{\mathrm{a}}$ célula discoidal.

Genitália. Edeago subcilíndrico, afilado distalmente; face dorsal com uma fileira de dentículos escamiformes muito tênues e espaçados de cada lado nos dois quartos medianos, divergentes entre si. Parâmeros achatados lateralmente na metade distal, curvados para cima e para dentro no terço distal; ápice em forma de gancho, pouco esclerotinizado, curvado para baixo; pilosidade longa e homogênea distribuída ao longo dos bordos superior e inferior, ao nível do terço distal. Placas laterais do pigóforo com o dente apical inconspícuo, situado no ângulo central; dente lateral bem desenvolvido, localizado no terço mediano, distintamente dirigido para baixo e com o ápice arredondado. Placa subgenital subtriangular, quase duas vezes mais longa que larga basalmente.

Fêmea. Difere por apresentar menores proporções, coloração mais clara e pela conformação dos processos supraumerais menos prismática.
Material examinado. Argentina, Jujuy: Volcán, III.1969 (Golbach), 1 macho (FML; holótipo); Santiago del Estero: Lago Muyo, IV.1957 (Golbach), 1 fêmea (FCNM; alótipo).

Distribuição geográfica. Argentina: Jujuy e Santiago del Estero (RemEs-LenICov 1973).

Localidade-tipo. Argentina, Jujuy: Volcán.

Notas sobre os tipos. O holótipo macho está depositado na FML, em razoável estado de conservação, montado em triângulo, com a região ventral da cabeça colada no triângulo e com o abdome dissecado. Faltam a porção distal da tégmina direita a partir da $1^{\text {a }}$ célula apical e o trocânter, fêmur, tíbia e tarso II direitos. Segundo a descrição original existem o alótipo fêmea e um parátipo macho também na FML, mas o alótipo foi localizado na FCNM.

Planta hospedeira. Desconhecida.

Comentários. Esta espécie foi interpretada com base principalmente no holótipo. A falta de uma série mais representativa não permite concluir se as discrepâncias apresentadas pelo alótipo são próprias do dimorfismo sexual, variações ou se os tipos não são conspecíficos.

Difere das demais espécies notadamente pelo padrão de coloração e pelo aspecto da aresta $\mathrm{M}$.

\section{Ceresa cavicornis Stål, 1859 Figs 100-106}

Ceresa cavicornis Stål, 1859: 284; Metcalf \& Wade, 1965: 860 (cat.); Remes-Lenicov, 1973: 116, lám. XXIV, figs 177 a 185 (rdescr., gen. masc. fem.); Kopp \& Yonke, 1979: 23, figs 271 a 278 (list.), 19 e 24 (not.); McKamey, 1998: 244 (cat.).

Medidas. Macho/fêmea. Largura da cabeça: 2,72/2,76; comprimento da cabeça: 1,36/1,38; distância entre os ângulos umerais: 2,84/2,88; distância entre os ápices dos processos supra-umerais: 4,04/4,68; comprimento do pronoto: 7,25/7,67; comprimento total: 7,92/8,08.

Descrição. Macho. Coloração geral ferruginosa, com máculas amareladas, mais clara no espaço entre os processos supra-umerais e nas áreas semicirculares. Face ventral dos processos supra-umerais acastanhada; aresta $\mathrm{M}$ e duas faixas que partem da face posterior dos processos supra-umerais em direção às áreas semicirculares amareladas; porção apical dos processos supra-umerais e ápice do pronoto negros. Tégminas hialinas, com uma mácula acastanhada ao longo das $1^{\text {a }}$ e $2^{\text {a }}$ células discoidais e da $2^{\text {a }}$ célula apical; veias acastanhadas. Região ventral do corpo e pernas ferruginosas.

Cabeça com a superfície fortemente estriada, corrugada no frontoclípeo e nos lóbulos supra-antenais. Sutura coronal atingindo a base do frontoclípeo, mais marcada junto a margem superior. Espaço interocelar convexo, espaços ocelo-oculares deprimidos. Lóbulos supra-antenais escavados, com as margens sinuosas. Frontoclípeo sublosângico, metade distal com os bordos laterais chanfrados e dirigida para baixo.

Pronoto com pontuação homogênea, um pouco abaula-

Revista Brasileira de Zoologia 21 (4): 671-738, dezembro 2004 
do nas regiões adjacentes às impressões semicirculares, regularmente elevado atrás do espaço entre os processos supraumerais, gradualmente em declive e afilado para o ápice após o ponto mais elevado e não constricto ao nível do ângulo interno das tégminas. Metopídio trapezoidal, com as impressões musculares em forma de L invertido. Lóbulos pós-oculares com a superfície corrugada, calosos ao nível do ângulo externo dos olhos. Sulcos supra-umerais bem marcados, regiões supraumerais com a superfície pontuada. Processos supra-umerais desenvolvidos, prismáticos, retos na metade distal, dirigidos para frente e para os lados, inclinados para cima e com os ápices voltados para os lados; face dorsal arredondada, face posterior pontuada na metade basal e corrugada na metade distal; espaço entre eles côncavo; arestas A e P aparentes na metade distal; aresta $\mathrm{M}$ pronunciada em toda a sua extensão; espaço anterior a aresta $\mathrm{M}$ normal, espaço posterior a aresta $\mathrm{M}$ escavado. Impressões semicirculares pouco distintas, áreas semicirculares planas e não impressas. Carena dorsal cortante a partir do ponto mais elevado do pronoto. Ápice ultrapassando a altura da base da $3^{\text {a }}$ célula apical das tégminas.

Tégminas com a veia $\mathrm{R} 1$ originando-se na $1^{\mathrm{a}}$ ou na $2^{\mathrm{a}}$ célula discoidal.

Genitália. Edeago subcilíndrico, afilado distalmente; face dorsal com uma fileira de dentículos de cada lado nos dois quartos medianos, divergentes entre si. Parâmeros subcilíndricos, curvados para dentro na metade distal, afilados e um pouco achatados lateralmente na porção distal; ápice fusiforme, mais esclerotinizado, com uma margem cortante no bordo superior e com a ponta discretamente voltada para fora; pilosidade heterogênea distribuída ao longo dos bordos superior e inferior, também um pouco na face interna, ao nível do terço distal, localizada mais distalmente no bordo superior e mais proximalmente no bordo inferior. Placas laterais do pigóforo com o dente apical proeminente, situado no ângulo anterior; dente lateral bem desenvolvido, localizado no terço mediano, curvado para baixo e para trás, com o ápice arredondado. Placa subgenital oblonga, quase duas vezes mais longa que larga medianamente.

Fêmea. Semelhante ao macho, apenas um pouco maior.

Material examinado. BRASIL, Santa Catarina: Rio Vermelho, sem data (sem coletor), 1 fêmea (MZUSP); Rio Grande do Sul: Porto Alegre, vila Oliva, II.1950 (Becker), 1 fêmea (MZUSP); Pelotas, 1940 (sem coletor), 1 macho (MZUSP). Sem indicação de localidade, sem data (sem coletor), 1 macho (FCNM).

Distribuição geográfica. Brasil: Paraná (Remes-Lenicov 1973), Santa Catarina e Rio Grande do Sul. Argentina: Buenos Aires (Remes-Lenicov 1973). Uruguai: Montevideo (StÅL, 1859).

Localidade-tipo. “...Monte-Video.” (STÅL, 1859).

Notas sobre o tipo. O holótipo está depositado no NR. O exame de fotografias do exemplar mostrou que se encontra em razoável estado de conservação, alfinetado e com o abdome dissecado, e com o pronoto um pouco deslocado.

Planta hospedeira. Desconhecida.

Comentários. Esta espécie foi interpretada com base na descrição original, na redescrição e ilustrações de REMES-LENICOV (1973), nas ilustrações de Kopp \& YonKe (1979) e em fotografias do holótipo.

Embora o holótipo apresente a veia $\mathrm{R} 1$ das tégminas, ao menos a da esquerda, originando-se exatamente entre a $1^{\mathrm{a}}$ e $2^{\mathrm{a}}$ células discoidais, o material examinado inclui exemplares que apresentam a veia $\mathrm{R} 1$ das tégminas originando-se tanto na $1^{\mathrm{a}}$ como na $2^{\mathrm{a}}$ célula discoidal. Preferimos incluir a espécie dentre as que apresentam a veia $\mathrm{R} 1$ das tégminas originando-se na $1^{\text {a }}$ célula discoidal, devido a sua similaridade com $C$. prosocera Remes-Lenicov, pelos caracteres da cabeça e pronoto, das estruturas da genitália masculina e da distribuição geográfica conhecida.

Foram observadas variações acentuadas na direção e inclinação dos processos supra-umerais.

Difere das demais espécies notadamente pelo aspecto grosseiro de esculturação da cabeça e do pronoto e por apresentar o ápice do pronoto quase atingindo o ângulo externo da $3^{\text {a }}$ célula apical das tégminas.

\section{Ceresa prosocera Remes-Lenicov, 1973 Figs 107-113}

Ceresa prosocera Remes-Lenicov, 1973: 126, lám. XXVIII, figs 211 a 219; McKamey, 1998: 246 (cat.).

Medidas. Fêmea (parátipo). Largura da cabeça: 2,92; comprimento da cabeça: 1,46; distância entre os ângulos umerais: 3,00; distância entre os ápices dos processos supra-umerais: 1,80 ; comprimento do pronoto: 7,00; comprimento total: 8,58.

Descrição. Fêmea. Coloração geral amarelada. Faces dorsal, ventral e posterior dos processos supra-umerais, faixas que partem da face posterior dos processos supra-umerais em direção às áreas semicirculares, bífidas a partir da altura dos ângulos umerais, e faixa ao longo da carena dorsal, ao nível das regiões adjacentes às impressões semicirculares, acastanhadas; aresta $\mathrm{M}$ amarelada; porção apical dos processos supra-umerais e ápice do pronoto negros. Tégminas hialinas, com uma mácula acastanhada ao nível da $2^{\mathrm{a}}$ célula discoidal e das $1^{\mathrm{a}}, 2^{\mathrm{a}}$ e $3^{\mathrm{a}}$ células apicais; veias acastanhadas. Região ventral do corpo e pernas amareladas.

Cabeça calosa junto a margem superior na direção dos ocelos, com a superfície fortemente estriada, corrugada no frontoclípeo e nos lóbulos supra-antenais. Sutura coronal atingindo a base do frontoclípeo, mais marcada junto a margem superior. Espaço interocelar convexo, espaços ocelo-oculares deprimidos. Lóbulos supra-antenais escavados, com as margens sinuosas. Frontoclípeo sublosângico, metade distal com os bordos laterais inteiros e dirigida para trás.

Pronoto com pontuação homogênea, não abaulado nas regiões adjacentes às impressões semicirculares, fracamente elevado atrás do espaço entre os processos supra-umerais, levemente em declive e afilado para o ápice após o ponto mais elevado e não constricto ao nível do ângulo interno das 
tégminas. Metopídio tapezoidal, com as impressões musculares em forma de L invertido. Lóbulos pós-oculares com a superfície corrugada, calosos ao nível do ângulo externo dos olhos. Sulcos supra-umerais pouco marcados, regiões supraumerais com a superfície pontuada. Processos supra-umerais desenvolvidos, prismáticos, retos na metade distal, dirigidos para frente, inclinados para cima e com os ápices voltados para os lados; face dorsal arredondada, face posterior pontuada na metade basal e corrugada na metade distal; espaço entre eles convexo; arestas A e P aparentes na metade distal; aresta M pronunciada em toda a sua extensão; espaço anterior a aresta M normal, espaço posterior a aresta $M$ escavado. Impressões semicirculares pouco distintas, áreas semicirculares planas e não impressas. Carena dorsal arredondada a partir do ponto mais elevado do pronoto, cortante apenas em sua porção distal. Ápice não atingindo a altura da base da $3^{\text {a }}$ célula apical das tégminas. discoidal.

Tégminas com a veia $\mathrm{R} 1$ originando-se na $1^{\mathrm{a}}$ célula

Macho. Não examinado, apenas as estruturas da genitália (cf. em Notas sobre os tipos).

Genitália. Edeago subcilíndrico, afilado distalmente; face dorsal com uma fileira de dentículos de cada lado nos dois quartos medianos, um pouco divergentes entre si. Parâmeros subcilíndricos, curvados para dentro, afilados e achatados lateralmente na porção distal; ápice em forma de faca, mais esclerotinizado, com a margem do bordo superior mais cortante; pilosidade heterogênea distribuída ao longo dos bordos superior e inferior, também um pouco na face interna, ao nível do terço distal, mais densa no bordo inferior. Placas laterais do pigóforo com o dente apical proeminente, situado no ângulo anterior; dente lateral bem desenvolvido, localizado no terço mediano, dirigido para baixo e para trás, com o ápice arredondado. Placa subgenital oblonga, quase duas vezes mais longa que larga medianamente.

Material examinado. Urugual, Rivera: Ruta 27, Arroyo Cuñapirú, 20.II.1962 (M.A. Monné \& P.R. San Martín), 1 macho e 2 fêmeas (FCNM; holótipo macho (genitália), alótipo (genitália) e parátipo, cf. em Notas sobre os tipos).

Distribuição geográfica. Uruguai: Rivera (Remes-Lenicov 1973).

Localidade-tipo. UruguaI, Rivera: Ruta 27, Arroyo Cuñapirú.

Notas sobre os tipos. A obtenção dos tipos para estudo foi desastrosa. Segundo a lista de remessa da FCNM, foram enviados o holótipo macho e o alótipo fêmea. No interior da embalagem, dilacerada, além de tipos de outras espécies foram encontrados dois alfinetes, cada qual com um suporte de isopor, etiqueta de procedência, etiqueta com o número 4108, microtubo com o abdome dissecado e, respectivamente, etiquetas de holótipo macho e alótipo fêmea com o nome da espécie manuscrito pela autora, porém sem os respectivos exemplares! Solto no fundo da caixa foi achado um exemplar fêmea, microalfi- netado e com o abdome não dissecado, o qual certamente estava espetado em um dos suportes e seja um dos parátipos referidos na descrição original. Consulta adicional feita a FCNM não possibilitou saber se restou algum exemplar da série-tipo na instituição, mas é quase certo que os demais tipos tenham sido perdidos na remessa da FCNM.

O parátipo examinado está em bom estado de conservação. O ápice do pronoto está quebrado, a tégmina direita com o limbo rasgado entre as $4^{\mathrm{a}}$ e $5^{\mathrm{a}}$ células apicais e falta o tarso II esquerdo.

Planta hospedeira. Desconhecida.

Comentários. Esta espécie é semelhante a C. cavicornis Stål. Difere dela e das demais espécies notadamente pelo padrão de coloração e pela direção dos processos supra-umerais.

\section{Ceresa brunnicornis (Germar, 1835) Figs 114-120}

Smilia brunnicornis Germar, 1835: 235.

Ceresa brunnicornis; Metcalf \& Wade, 1965: 845 (cat.); RemesLenicov, 1973: 67, lám. III, figs 14 a 22 (gen. masc. fem., biol., plant. hosp.), 82 (not.); Kopp \& Yonke, 1979: 23 (list.); McKamey, 1998: 244 (cat.).

Medidas. Macho/fêmea. Largura da cabeça: 2,72/2,96; comprimento da cabeça: 1,36/1,48; distância entre os ângulos umerais: 2,80/3,08; distância entre os ápices dos processos supra-umerais: 4,68/5,50; comprimento do pronoto: $6,75 / 7,42$; comprimento total: 7,83/8,42.

Descrição. Macho. Coloração geral amarelada. Faces ventral e posterior dos processos supra-umerais, regiões supraumerais e carena dorsal a partir do ponto mais elevado do pronoto, acastanhadas; aresta $\mathrm{M}$ esbranquiçada na metade basal; ápices dos processos supra-umerais e do pronoto negros. Tégminas hialinas, veias amareladas. Face ventral da cabeça, pleuras torácicas, esternos abdominais e metade basal das placas laterais do pigóforo, enegrecidas. Pernas amareladas, com as coxas maculadas de negro.

Cabeça com a superfície fracamente estriada, lisa no frontoclípeo e nos lóbulos supra-antenais. Sutura coronal atingindo a base do frontoclípeo. Espaço interocelar plano, espaços ocelo-oculares planos. Lóbulos supra-antenais planos, com as margens arredondadas. Frontoclípeo sublosângico, metade distal com os bordos laterais chanfrados e dirigida para baixo.

Pronoto com pontuação heterogênea, não abaulado nas regiões adjacentes às impressões semicirculares, regularmente elevado atrás do espaço entre os processos supra-umerais, gradualmente em declive e afilado para o ápice após o ponto mais elevado e constricto ao nível do ângulo interno das tégminas. Metopídio trapezoidal, com as impressões musculares em forma de $\mathrm{V}$ invertido. Lóbulos pós-oculares com a superfície corrugada, sem modificações ao nível do ângulo externo dos olhos. Sulcos supra-umerais bem marcados, regiões supraumerais com a superfície pontuada. Processos supra-umerais

Revista Brasileira de Zoologia 21 (4): 671-738, dezembro 2004 


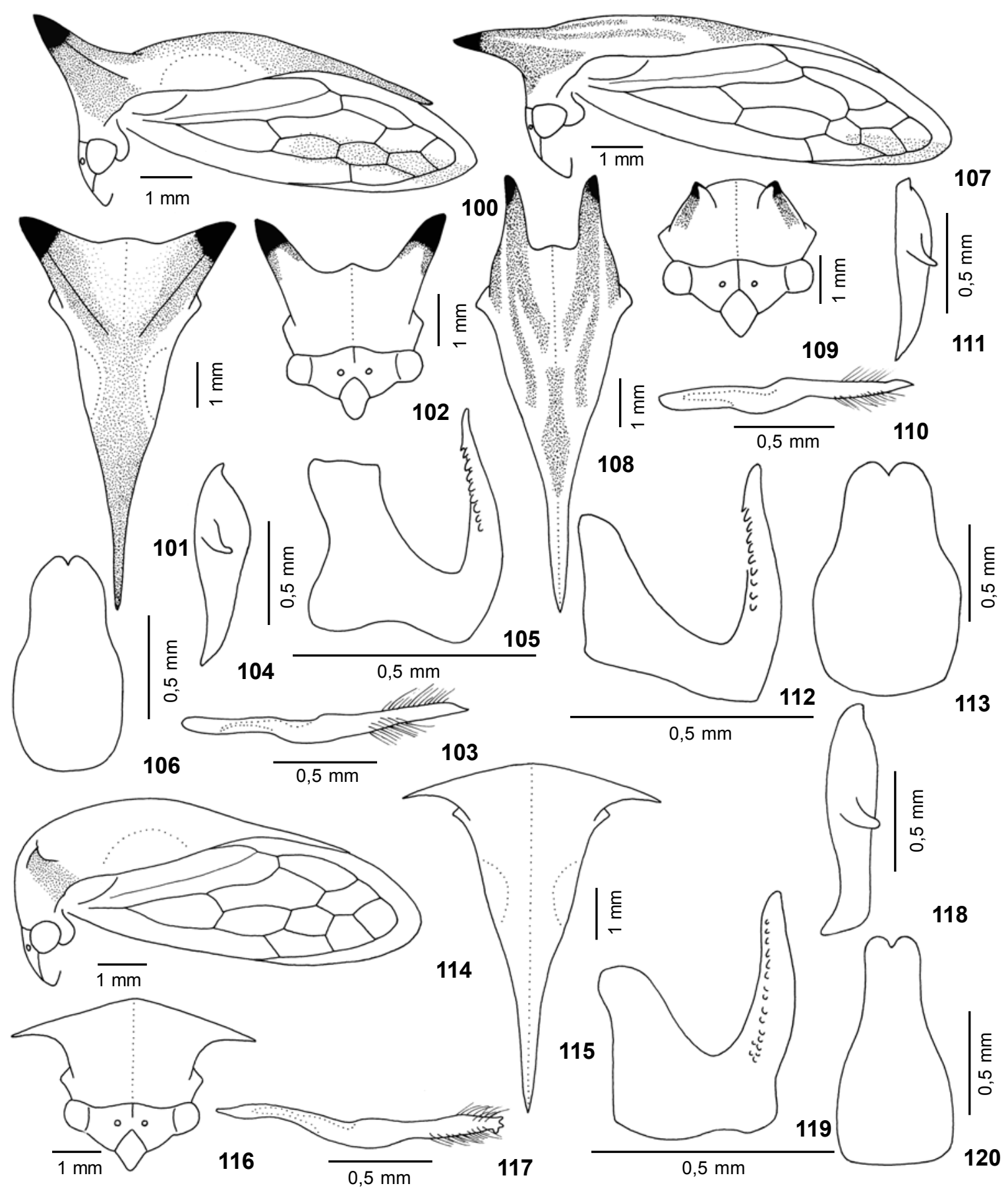

Figuras 100-120. (100-106) Ceresa cavicornis: (100) cabeça, pronoto e tégmina, vista lateral; (101) pronoto, vista dorsal; (102) cabeça e pronoto, vista frontal; (103) parâmero esquerdo, vista lateral; (104) placa lateral esquerda do pigóforo, vista lateral; (105) edeago, vista lateral; (106) placa subgenital, vista ventral; (107-113) Ceresa prosocera: (107) cabeça, pronoto e tégmina, vista lateral; (108) pronoto, vista dorsal; (109) cabeça e pronoto, vista frontal; (110) parâmero esquerdo, vista lateral; (111) placa lateral esquerda do pigóforo, vista lateral; (112) edeago, vista lateral; (113) placa subgenital, vista ventral; (114-120) Ceresa brunnicornis: (114) cabeça, pronoto e tégmina, vista lateral; (115) pronoto, vista dorsal; (116) cabeça e pronoto, vista frontal; (117) parâmero esquerdo, vista lateral; (118) placa lateral esquerda do pigóforo, vista lateral; (119) edeago, vista lateral; (120) placa subgenital, vista ventral.

Revista Brasileira de Zoologia 21 (4): 671-738, dezembro 2004 
desenvolvidos, prismáticos, retos na metade distal, dirigidos para os lados, inclinados para baixo e com os ápices voltados para os lados e para trás; face dorsal arredondada, face posterior pontuada na metade basal e corrugada na metade distal; espaço entre eles convexo; arestas A e P aparentes na metade distal; aresta $\mathrm{M}$ pronunciada na metade distal e apenas intumescida na metade basal; espaço anterior a aresta $\mathrm{M}$ normal, espaço posterior a aresta $\mathrm{M}$ escavado. Impressões semicirculares pouco distintas, áreas semicirculares planas e não impressas. Carena dorsal cortante a partir do ponto mais elevado do pronoto. Ápice não atingindo a altura da base da $3^{\text {a }}$ célula apical das tégminas.

Tégminas com a veia $\mathrm{R} 1$ originando-se na $1^{\mathrm{a}}$ célula discoidal.

Genitália. Edeago um pouco achatado ântero-posteriormente; face dorsal com uma fileira de dentículos de cada lado em toda a sua extensão, mais proeminentes na metade distal e algo em mosaico na porção basal. Parâmeros achatados lateralmente na metade distal, curvados para dentro e estrangulados pré-apicalmente no terço distal; ápice tridenteado, mais esclerotinizado, com duas pontas dirigidas para trás e uma ponta maior voltada para baixo; pilosidade heterogênea distribuída ao longo dos bordos superior e inferior, ao nível do terço distal, mais extensa no bordo inferior. Placas laterais do pigóforo com o dente apical bem intumescido, situado no ângulo central; dente lateral bem desenvolvido, localizado no terço mediano, fracamente dirigido para baixo e com o ápice arredondado. Placa subgenital duas vezes mais longa que larga basalmente, estreitando-se após a região mediana.

Fêmea. Semelhante ao macho, apenas um pouco maior. Material examinado. Brasil, Minas Gerais: Sete Lagoas, III.1963 (F. Werner, U. Martins \& L. Silva), 2 machos e 8 fêmeas (MZUSP); Paraná: Curitiba, 17.IX.1984 (Creão), 9 machos e 2 fêmeas (DZUP); Santa Catarina: Caçador, 16.X.1981 (A.I. Orth), 1 macho (DZUP); Itapiranga, 30.XII.1981 (A.I. Orth), 1 macho (DZUP); Nova Teutônia, 18.X.1952 (F. Plaumann), 3 machos e 4 fêmeas (DZUP); Nova Teutônia, 22.X.1952 (F. Plaumann), 1 macho e 1 fêmea (DZUP); Lajes, 22.VII.1986 (D.R. Jesus), 2 machos e 1 fêmea (DZUP); Rio Grande do Sul: Barão de Cotegipe, 15.I.1967 (F. Giacomel), 1 fêmea (DZUP); Barão de Cotegipe, 21.I.1967 (F. Giacomel), 1 fêmea (DZUP). Argentina, Buenos Aires: Buenos Aires, Tigre, 8.II.1920 (Cornell Univ. Exp.), 1 fêmea (CU); La Plata, 9.X.1968 (Tesón \& Marino), 1 fêmea (FCNM); Moreno, X.1970 (M.A. Fritz), 6 machos e 4 fêmeas (DZUP); Puán, Felipe Solá, XI.1959 (A. Martinez), 1 macho (MZUSP); sem indicação de localidade, sem data (sem coletor), 1 macho (FCNM).

Distribuição geográfica. Brasil: Rio Grande do Sul (RemesLenicov 1973), Minas Gerais, Paraná e Santa Catarina. Argentina: Buenos Aires (Germar 1835), Salta, Formosa, Chaco, Misiones, Tucumán, Corrientes, Santa Fe, Córdoba, Entre Ríos e La Pampa (Remes-Lenicov 1973).

Localidade-tipo. "Habitat in Buenos-Ayres." (Germar 1835)
Notas sobre o(s) tipo(s). Veja comentários apresentados sob este item para C. axillaris (Germar).

Plantas hospedeiras. "...haciendo daño en acacias, en sarmientos de vid y es muy frequente encontrarla en gran número en alfalfa a la cual también perjudica." (Torres 1946). “...sobre trigo (Triticum aestivum L.), alfalfa (Medicago sativa L.) y papa (Solanum tuberosum L.)." (Remes-Lenicov 1973).

Comentários. Esta espécie foi interpretada em consonância com Torres (1946) e com Remes-Lenicov (1973), cujas redescrições e ilustrações se ajustam muito bem a descrição original.

Não obstante, uma definição futura do tipo de Smilia brunnicornis Germar poderia alterar a interpretação adotada para a espécie.

Foram observadas variações na coloração, principalmente nas tégminas e na região ventral do corpo, no padrão de pontuação do pronoto e na extensão e inclinação dos processos supra-umerais.

Difere das demais espécies notadamente pela aparência brilhante do tegumento, por apresentar o metopídio e o espaço entre os processos supra-umerais formando uma convexidade contínua e bem pronunciada e pelo aspecto da aresta $\mathrm{M}$.

\section{Ceresa cuprea Funkhouser, 1927 Figs 121-127}

Ceresa cuprea Funkhouser, 1927: 160, pl. XVII, fig. 3; Metcalf \& Wade, 1965: 861 (cat.); Remes-Lenicov, 1973: 71, lám. IV e V, figs 23 a 31 (gen. masc. fem.); Kopp \& Yonke, 1974: 137 (rep. tip.); McKamey, 1998: 245 (cat.).

Medidas. Macho/fêmea. Largura da cabeça: 3,20/3,36; comprimento da cabeça: 1,52/1,60; distância entre os ângulos umerais: 3,28/3,48; distância entre os ápices dos processos supra-umerais: 5,00/5,33; comprimento do pronoto: 7,00/7,25; comprimento total: $8,67 / 8,67$.

Descrição. Macho. Coloração geral acastanhada, com máculas amareladas notadamente no metopídio e no espaço entre os processos supra-umerais, mais clara na cabeça e nos lados do pronoto. Face ventral dos processos supra-umerais, regiões supra-umerais e lóbulos pós-oculares, amarronzados; aresta $\mathrm{M}$ amarelada na metade basal; carena dorsal enegrecida a partir do ponto mais elevado do pronoto; porção distal dos processos supra-umerais e ápice do pronoto negros. Tégminas e veias ambarinas. Região ventral do corpo ferruginosa, com as pleuras torácicas e esternos abdominais enegrecidos. Pernas ferruginosas, com as coxas maculadas de negro.

Cabeça com a superfície fortemente estriada, corrugada no frontoclípeo e nos lóbulos supra-antenais. Sutura coronal atingindo a base do frontoclípeo. Espaço interocelar convexo, espaços ocelo-oculares planos. Lóbulos supra-antenais escavados, com as margens sinuosas. Frontoclípeo sublosângico, metade distal com os bordos laterais chanfrados e dirigida para baixo.

Pronoto com pontuação homogênea, não abaulado nas regiões adjacentes às impressões semicirculares, regularmente

Revista Brasileira de Zoologia 21 (4): 671-738, dezembro 2004 
elevado atrás do espaço entre os processos supra-umerais, gradualmente em declive e afilado para o ápice após o ponto mais elevado e constricto ao nível do ângulo interno das tégminas. Metopídio trapezoidal, com as impressões musculares em forma de $\mathrm{V}$ invertido. Lóbulos pós-oculares com a superfície corrugada, sulcados ao nível do ângulo externo dos olhos. Sulcos supra-umerais bem marcados, regiões supra-umerais com a superfície pontuada. Processos supra-umerais desenvolvidos, prismáticos, curvos na metade distal, dirigidos para os lados, inclinados para baixo e com os ápices voltados para os lados e para trás; face dorsal arredondada, face posterior pontuada na metade basal e corrugada na metade distal; espaço entre eles convexo; arestas A e P aparentes na metade distal; aresta $\mathrm{M}$ pronunciada em toda a sua extensão; espaço anterior a aresta $\mathrm{M}$ normal, espaço posterior a aresta $\mathrm{M}$ escavado. Impressões semicirculares pouco distintas, áreas semicirculares planas e bem impressas. Carena dorsal cortante a partir do ponto mais elevado do pronoto. Ápice não atingindo a altura da base da $3^{\mathrm{a}}$ célula apical das tégminas.

Tégminas com a veia $\mathrm{R} 1$ originando-se na $1^{\mathrm{a}}$ célula discoidal.

Genitália. Edeago achatado ântero-posteiormente, afilado para o ápice; face dorsal com uma fileira de dentículos de cada lado nos três quartos basais, delimitando denticulação em mosaico na metade distal. Parâmeros achatados lateralmente na metade distal, curvados para cima na região mediana e dirigidos para trás, um pouco curvados para dentro e ligeiramente alargados no terço distal; ápice laminar, mais esclerotinizado, com uma ponta voltada para baixo; pilosidade longa e heterogênea distribuída ao longo do terço distal do bordo superior, e externamente no bordo inferior, tufosa, ao nível da curvatura mediana. Placas laterais do pigóforo com o dente apical bem intumescido, situado no ângulo central; dente lateral bem desenvolvido, localizado no terço mediano, fracamente dirigido para baixo e com o ápice arredondado. Placa subgenital quase duas vezes mais longa que larga basalmente, estreitando-se após a região mediana.

Fêmea. Semelhante ao macho, apenas um pouco maior.

Material examinado. BrasiL, Goiás: Jataí, XI.1972 (F.M. Oliveira), 1 macho (DZUP); Minas Gerais: Aguas Vermelhas, XII.1983 (M. Alvarenga), 1 fêmea (DZUP); Araxá, 6.XI.1965 (C. \& T. Elias), 1 fêmea (DZUP); Araxá, 14.XI.1965 (C. Elias), 1 macho (DZUP); Tapira, 27.V.1965 (C. Elias), 1 fêmea (DZUP); São João Batista da Glória, V.1961 (C. Elias), 1 macho (DZUP); Passos, 22-26.V.1962 (C. Elias), 1 macho (DZUP); Passos, 1217.XI.1962 (C. Elias), 1 macho e 1 fêmea (DZUP); Passos, 1015.XII.1962 (C. Elias), 1 macho e 4 fêmeas (DZUP); Passos, 1722.XII.1962 (C. Elias), 1 macho e 3 fêmeas (DZUP); Passos, 2431.XII.1962 (C. Elias), 1 fêmea (DZUP); Passos, 13-19.III.1963 (C. Elias), 1 fêmea (DZUP); Passos, 9-15.X.1963 (C. Elias), 1 fêmea (DZUP); Passos, 4-9.XI.1963 (C. Elias), 1 macho (DZUP); São Paulo: Itapura, 1934 (sem coletor), 1 fêmea (MZUSP); Ilha Seca, 19-26.II.1940 (Com. Inst. O. Cruz), 1 fêmea (FIOC). ARGENTINA, Misiones: Villa Lanús, 10.II.1965 (Toga), 1 fêmea (FCNM).
Distribuição geográfica. Brasil: São Paulo (FunkHouser 1927a), Minas Gerais (Remes-Lenicov 1973) e Goiás. Argentina: Misiones e Corrientes (Remes-Lenicov 1973).

Localidade-tipo. “...at Bauru, S. Paulo, Brazil,..." (FunKHOUSER 1927a).

Notas sobre o tipo. O holótipo macho está depositado na CU. O exame de fotografias do exemplar mostrou que se encontra em razoável estado de conservação, alfinetado e com o abdome dissecado. É oportuno ressaltar que o abdome foi dissecado em 1988, atendendo a solicitação feita a CU para instruir o presente estudo.

Planta hospedeira. Desconhecida.

Comentários. Esta espécie foi interpretada com base na descrição e ilustração originais, na descrição e ilustrações de Remes-Lenicov (1973), em esquemas originais das estruturas da genitália do holótipo e em fotografias do holótipo.

Foram observadas variações na coloração geral e na extensão e inclinação dos processos supra-umerais, bem como na esclerotinização e conformação da metade distal dos parâmeros.

Esta espécie é muito semelhante à $C$. distans Butler, e também à C. brunnicornis (Germar) e C. nigripectus RemesLenicov, diferindo destas últimas pelos caracteres referidos na chave, bem como pelas diferenças ao nível das estruturas da genitália masculina.

Difere das demais espécies notadamente pelo tom bronzeado da coloração do pronoto, pelo aspecto contorcido da aresta $\mathrm{M}$ em sua porção mediana e por apresentar o pronoto fortemente constricto ao nível do ângulo interno das tégminas.

\section{Ceresa nigripectus Remes-Lenicov, 1973 Figs 128-134}

Ceresa nigripectus Remes-Lenicov, 1973: 80, lám. IX, figs 58 a 66; McKamey, 1998: 245 (cat.).

Ceresa cuprea; Kopp \& Yonke, 1979: 24, figs 258 a 265 (list.), non C. cuprea Funkhouser, 1927.

Medidas. Macho (holótipo)/fêmea (alótipo). Largura da cabeça: 2,76/2,96; comprimento da cabeça: 1,38/1,48; distância entre os ângulos umerais: $2,80 / 3,08$; distância entre os ápices dos processos supra-umerais: $4,36 / 5,25$; comprimento do pronoto: 6,33/6,83; comprimento total: 7,08/7,67.

Descrição. Macho. Coloração geral amarelada. Faces ventral e posterior dos processos supra-umerais, regiões supra-umerais e lóbulos pós-oculares, acastanhados; aresta M esbranquiçada na metade basal; ápices dos processos supra-umerais e do pronoto negros. Tégminas e veias hialinas. Região ventral do corpo amarelada, com as pleuras torácicas enegrecidas. Pernas amareladas, com as coxas maculadas de negro.

Cabeça com a superfície fortemente estriada, corrugada no frontoclípeo e nos lóbulos supra-antenais. Sutura coronal atingindo a base do frontoclípeo. Espaço interocelar plano, espaços ocelo-oculares planos. Lóbulos supra-antenais planos, 


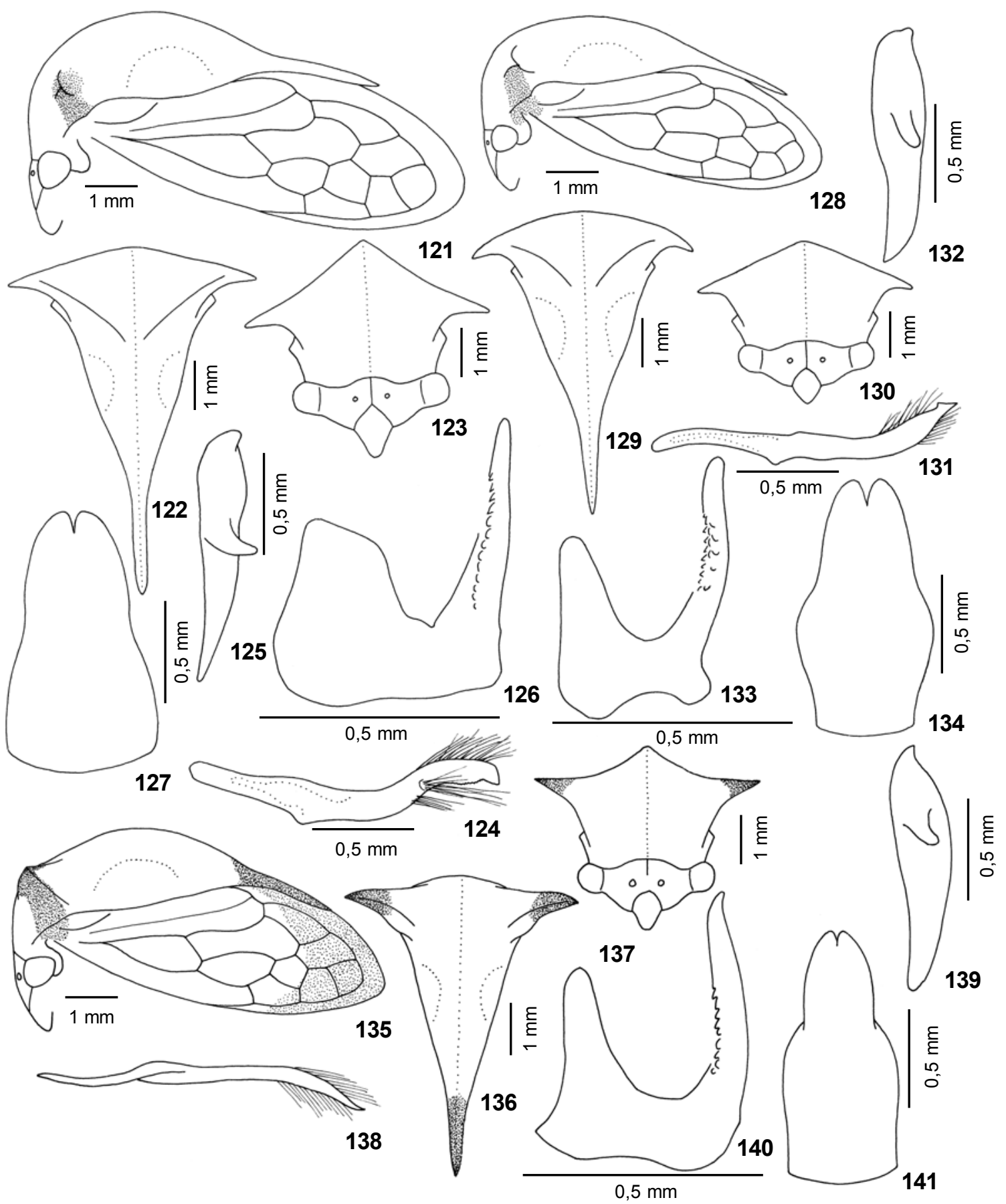

Figuras 121-141. (121-127) Ceresa cuprea: (121) cabeça, pronoto e tégmina, vista lateral; (122) pronoto, vista dorsal; (123) cabeça e pronoto, vista frontal; (124) parâmero esquerdo, vista lateral; (125) placa lateral esquerda do pigóforo, vista lateral; (126) edeago, vista lateral; (127) placa subgenital, vista ventral; (128-134) Ceresa nigripectus: (128) cabeça, pronoto e tégmina, vista lateral; (129) pronoto, vista dorsal; (130) cabeça e pronoto, vista frontal; (131) parâmero esquerdo, vista lateral; (132) placa lateral esquerda do pigóforo, vista lateral; (133) edeago, vista lateral; (134) placa subgenital, vista ventral; (135-141) Ceresa maculipennis: (135) cabeça, pronoto e tégmina, vista lateral; (136) pronoto, vista dorsal; (137) cabeça e pronoto, vista frontal; (138) parâmero, apud REMEs-LeNICOv (1973); (139) placa lateral esquerda do pigóforo, vista lateral; (140) edeago, vista lateral; (141) placa subgenital, vista ventral. 
com as margens sinuosas. Frontoclípeo sublosângico, metade distal com os bordos laterais inteiros e dirigida para baixo.

Pronoto com pontuação homogênea, não abaulado nas regiões adjacentes às impressões semicirculares, regularmente elevado atrás do espaço entre os processos supra-umerais, gradualmente em declive e afilado para o ápice após o ponto mais elevado e não constricto ao nível do ângulo interno das tégminas. Metopídio trapezoidal, com as impressões musculares em forma de L invertido. Lóbulos pós-oculares com a superfície corrugada, sem modificações ao nível do ângulo externo dos olhos. Sulcos supra-umerais bem marcados, regiões supra-umerais com a superfície pontuada. Processos supra-umerais rudimentares ou desenvolvidos, prismáticos ou prismáticos na metade basal e cônicos na metade distal, retos na metade distal, dirigidos para os lados, inclinados para baixo e com os ápices voltados para os lados e para trás; face dorsal arredondada, face posterior pontuada na metade basal e corrugada na metade distal; espaço entre eles convexo; arestas A e P ausentes ou aparentes na metade distal; aresta $\mathrm{M}$ pronunciada somente na metade basal ou pronunciada em toda a sua extensão; espaço anterior a aresta $\mathrm{M}$ normal, espaço posterior a aresta $\mathrm{M}$ escavado. Impressões semicirculares pouco distintas, áreas semicirculares planas e não impressas. Carena dorsal cortante a partir do ponto mais elevado do pronoto. Ápice atingindo a altura da base da $3^{\text {a }}$ célula apical das tégminas.

Tégminas com a veia $\mathrm{R} 1$ originando-se na $1^{\mathrm{a}}$ célula discoidal.

Genitália. Edeago subcilíndrico; face dorsal com uma fileira tripla e irregular de dentículos de cada lado nos dois quartos medianos, mais proeminentes na porção superior. Parâmeros achatados lateralmente, curvados para cima e para dentro no terço distal; ápice laminar, mais esclerotinizado, diagonalmente truncado, com uma formação denticular no ângulo superior e com uma margem cortante no bordo inferior; pilosidade longa e homogênea distribuída na face interna ao nível do terço distal. Placas laterais do pigóforo com o dente apical proeminente, situado no ângulo posterior; dente lateral bem desenvolvido, localizado no terço mediano, distintamente dirigido para baixo e com o ápice arredondado. Placa subgenital dilatada na região mediana, mais de duas vezes longa que larga basalmente.

Fêmea. Semelhante ao macho, apenas um pouco maior.

Material examinado. Brasil, Rio Grande do Sul: São Leopoldo, XII.1927 (sem coletor), 1 fêmea (MA); São Leopoldo, I.1933 (sem coletor), 1 macho e 2 fêmeas (MA); São Leopoldo, I.1933 (sem coletor), 2 machos (MZUSP); Porto Alegre, 22.XII. 1950 (J. Becker), 1 macho (MN); Pelotas, 27.III.1959 (C.M. Biezanko), 1 macho (DZUP); Pelotas, 5.III.1961 (C.M. Biezanko), 1 fêmea (DZUP); Estação Ecológica do Taim, margens do Arroio Taim, 5.II.1981 (J. Grazia), 2 machos (UFRGS); Estação Ecológica do Taim, 23.III-4.IV.1981 (J. Grazia), 7 fêmeas (UFRGS); Estação Ecológica do Taim, 1.IV.1981 (J. Grazia), 1 fêmea (UFRGS). Bolívia, Tarija: Bermejo, XI.1969 (Golbach), 1 fêmea (FML). ARGENTINA, Jujuy: San Juancito, 27.II.1920 (Cornell Univ. Exp.), 1 fêmea (CU; identificado como C. brunnicornis (Germar), W.D. Funkhouser det., e como C. cuprea Funkhouser, D.D. Kopp det.); sem indicação de localidade, 29.II.1920 (Cornell Univ. Exp.), 1 fêmea (CU; identificado como C. pauperata Berg, W.D. Funkhouser det.); Salta: Pocitos, II.1961 (A. Martinez), 2 fêmeas (MZUSP); 25 km N Guemes, 10.X.1968 (L.E. Peña), 1 macho (UPR); entre Galpon e Trancas, 1.V.1958 (Olivier), 1 fêmea (FCNM; alótipo); Catamarca: Andalgalá, El Rincón, 2.X.1968 (L.E. Peña), 1 macho (UPR); Santiago del Estero: Clodomira, 22.II.1920 (Cornell Univ. Exp.), 1 fêmea (CU; identificado com C. pauperata Berg, W.D. Funkhouser det.); Chilca, 7.VI.1945 (Maldonado), 1 macho (FCNM; holótipo); Lago Muyo, IV.1957 (Golbach), 1 fêmea (FML); Tucumán: La Vinita, 5.X.1968 (L.E. Peña), 1 fêmea (UPR); La Rioja: Chilecito, 29.II.1920 (R.G. Harris, Cornell Univ. Exp.), 1 fêmea (CU; identificado como C. brunncicornis (Germar), W.D. Funkhouser det.); Santa Fe: sem indicação de localidade, 19.II.1920 (Cornell Univ. Exp.), 5 machos e 3 fêmeas (CU; identificado como C. brunnicornis (Germar), W.D. Funkhouser det.); sem indicação de localidade, 19.II.1920 (Cornell Univ. Exp.), 1 fêmea (CU; identificado como C. brunnicornis (Germar), W.D. Funkhouser det., e como C. cuprea Funkhouser, D.D. Kopp det.); San Juan: Pie de Palo, 11.III.1920 (Cornell Univ. Exp.), 1 macho (CU; identificado como C. pauperata Berg, W.D. Funkhouser det.); Córdoba: sierra de Córdoba, Cosquin, 1-9.III.1920 (Cornell Univ. Exp.), 1 macho (CU; identificado como C. brunnicornis (Germar), W.D. Funkhouser det.); sierra de Córdoba, Cosquin, 1-9.III.1920 (Cornell Univ. Exp.), 1 macho (CU; identificado como $C$. brunnicornis (Germar), W.D. Funkhouser det., e como C. cuprea Funkhouser, D.D. Kopp det.); Balnearia, 2.III.1971 (Fritz), 1 macho e 1 fêmea (DZUP); Mendoza: Potrerillos, 4000 ft, 1620.III.1920 (Cornell Univ. Exp.), 1 macho (CU; identificado como C. pauperata Berg, W.D. Funkhouser det.); "C.S. Reed", sem data (sem coletor), 3 machos e 1 fêmea (CU; identificado como $C$. pauperata Berg, W.D. Funkhouser det.); sem indicação de localidade, 1907 (A.C. Jensen-Haarup) 1 macho e 1 fêmea (LU); Buenos Aires: Buenos Aires, San Isidro, XII.1961 (A. Martinez), 1 fêmea (MZUSP); Moreno, X.1970 (M.A. Fritz), 6 fêmeas (DZUP); Pehuajó, 100 m, 2.IV.1974 (Bordón), 1 macho (CB); La Pampa: General Acha, 2.IV.1974 (Bordón), 1 fêmea (CB); Sem indicação de Província: Laguna Paiva, 21-23.II.1920 (Cornell Univ. Exp.), 1 fêmea (CU; identificado como C. pauperata Berg, W.D. Funkhouser det.).

Distribuição geográfica. BRASIL: Rio Grande do Sul. Bolívia: Tarija. Argentrna: Jujuy, Salta, Formosa, Misiones, Santiago del Estero, Tucumán, Santa Fe, San Juan, Córdoba e Buenos Aires (Remes-Lenicov, 1973), Catamarca, La Rioja, Mendoza e La Pampa. Localidade-tipo. Argentina, Santiago del Estero: Chilca.

Notas sobre os tipos. O holótipo macho está depositado na FCNM, em bom estado de conservação, montado em cartão, com as pernas coladas no cartão e com o abdome não dissecado. Segundo a descrição original, existem quatro parátipos machos e dois parátipos fêmeas na EEAT, o alótipo fêmea (examinado), quinze parátipos machos e quatorze 
parátipos fêmeas também na FCNM e dezessete parátipos machos e vinte e três parátipos fêmeas no MACNBR.

Plantas hospedeiras. "...sobre alfalfa (Medicago sativa L.); trigo (Triticum aestivum L.) y papa (Solanum tuberosum L.)" (REMES-LENICOV 1973).

Comentários. Dentre as espécies reconhecidas esta é a que apresenta a maior disformidade na extensão dos processos supra-umerais, cuja variação vai desde totalmente obsoletos até bem desenvolvidos, e com a metade distal cônica ou prismática.

Foram observadas também variações na coloração, principalmente na região ventral do corpo e no processo pronotal posterior, às vezes acastanhado, na aparência dos sulcos supraumerais e no grau de extensão do ápice do pronoto com relação a altura da base da $3^{\text {a }}$ célula apical das tégminas, bem como na direção do dente lateral das placas laterais do pigóforo.

Difere das demais espécies, além dos demais caracteres referidos na chave, notadamente por apresentar a aresta $\mathrm{M}$ sempre bem pronunciada e com aspecto porcelanizado na metade basal dos processos supra-umerais, mesmo nos indivíduos que apresentam os processos supra-umerais rudimentares.

\section{Ceresa maculipennis Remes-Lenicov, 1973 Figs 135-141}

Ceresa maculipennis Remes-Lenicov, 1973: 95, lám. XV, figs 103 a 109; McKamey, 1998: 245 (cat.).

Medidas. Macho (holótipo). Largura da cabeça: 2,72; comprimento da cabeça: 1,36; distância entre os ângulos umerais: 2,72 ; distância entre os ápices dos processos supraumerais: 4,24; comprimento do pronoto: 6,25 ; comprimento total: 7,25 .

Descrição. Macho. Coloração geral amarelada. Porção apical da face dorsal, face ventral e porção apical da face posterior dos processos supra-umerais, regiões supra-umerais, lóbulos pós-oculares e processo pronotal posterior, amarronzados; aresta $\mathrm{M}$ esbranquiçada na metade basal; ápices dos processos supra-umerais e do pronoto negros. Tégminas hialinas, amarronzadas na base e acastanhadas ao longo das células apicais e no limbo; veias amareladas. Região ventral do corpo amarelada, com as pleuras torácicas acastanhadas. Pernas amareladas.

Cabeça com a superfície fracamente estriada, lisa no frontoclípeo e nos lóbulos supra-antenais. Sutura coronal atingindo a base do frontoclípeo, mais marcada junto a margem superior. Espaço interocelar convexo, espaços ocelo-oculares planos. Lóbulos supra-antenais escavados, com as margens sinuosas. Frontoclípeo piriforme, metade distal com os bordos laterais inteiros e dirigida para baixo.

Pronoto com pontuação homogênea, abaulado nas regiões adjacentes às impressões semicirculares, regularmente elevado atrás do espaço entre os processos supra-umerais, gradualmente em declive e afilado para o ápice após o ponto mais elevado e constricto ao nível do ângulo interno das tégminas. Metopídio trapezoidal, com as impressões musculares em forma de L invertido. Lóbulos pós-oculares com a superfície corrugada, sem modificações ao nível do ângulo externo dos olhos. Sulcos supra-umerais bem marcados, regiões supraumerais com a superfície pontuada. Processos supra-umerais desenvolvidos, prismáticos, curvos na metade distal, dirigidos para os lados, inclinados para cima e com os ápices voltados para os lados; face dorsal arredondada, face posterior pontuada; espaço entre eles plano; arestas A e P aparentes na metade distal; aresta $\mathrm{M}$ pronunciada na metade distal e fortemente intumescida na metade basal; espaço anterior a aresta $\mathrm{M}$ intumescido, espaço posterior a aresta $\mathrm{M}$ escavado. Impressões semicirculares pouco distintas, áreas semicirculares planas e não impressas. Carena dorsal cortante a partir do ponto mais elevado do pronoto. Ápice não atingindo a altura da base da $3^{\mathrm{a}}$ célula apical das tégminas.

Tégminas com a veia $\mathrm{R} 1$ originando-se na $1^{\mathrm{a}}$ célula discoidal.

Genitália. Edeago subcilíndrico, com o ápice curvado para trás; face dorsal com uma fileira dupla de dentículos de cada lado nos dois quartos medianos. Parâmeros, segundo RemesLenicov (1973), “...estrechados regularmente hacia el ápice, tercio distal divergente y recurvado hacia arriba, com larga pilosidad en sus márgenes...". Placas laterais do pigóforo com o dente apical intumescido, situado no ângulo central; dente lateral bem desenvolvido, localizado no terço superior, diagonalmente dirigido para baixo e com o ápice arredodado. Placa subgenital mais de duas vezes longa que larga basalmente, estreitando-se após a região mediana.

Fêmea. Desconhecida.

Material examinado. Argentina, Corrientes: Manantiales, XII.1946 (Denier), 1 macho (FCNM; holótipo).

Distribuição geográfica. Argentina: Chaco, Misiones, Corrientes e Córdoba (Remes-Lenicov 1973).

Localidade-tipo. Argentina, Corrientes: Manantiales. A indicação “...Resistencia, Chaco." feita na descrição original está errada. A simples leitura do item Material estudado da referida descrição mostra que estes dados são pertinentes a um dos parátipos.

Notas sobre os tipos. O holótipo macho está depositado na FCNM, em razoável estado de conservação, montado em triângulo, com a região látero-ventral direita do tórax colada no triângulo e com o abdome dissecado. Faltam tarso I esquerdo, trocânter, fêmur, tíbia e tarso II e III esquerdos e trocânter, fêmur, tíbia e tarso I e II direitos. Os parâmeros não se encontram no microtubo apenso ao alfinete. Segundo a descrição original existem dois parátipos machos também na FCNM, um deles erroneamente citado precedido pelo símbolo de fêmea. Esta opinião é reforçada pelo fato da autora afirmar que a fêmea é desconhecida e de não ter apresentado ilustrações da genitália da mesma.

Planta hospedeira. Desconhecida.

Revista Brasileira de Zoologia 21 (4): 671-738, dezembro 2004 
Comentários. Difere das demais espécies notadamente pelo padrão de coloração e por apresentar a aresta $M$ fortemente intumescida na metade basal.

\section{Ceresa paulistana Remes-Lenicov, 1976 Figs 142-148}

Ceresa paulistana Remes-Lenicov, 1976: 45, lám. I, figs 1 a 9; McKamey, 1998: 245 (cat.).

Medidas. Macho (holótipo)/fêmea (alótipo). Largura da cabeça: 3,04/3,20; comprimento da cabeça: 1,52/1,60; distância entre os ângulos umerais: 3,12/3,40; distância entre os ápices dos processos supra-umerais: 5,50/5,33; comprimento do pronoto: 7,67/7,83; comprimento total: 9,33/9,25.

Descrição. Macho. Coloração geral ferruginosa, mais clara na cabeça. Metade distal da face dorsal, face ventral e face posterior dos processos supra-umerais, regiões supra-umerais e banda transversal na região posterior do pronoto, amarronzadas; ápices dos processos supra-umerais e do pronoto negros. Tégminas ambarinas, com uma mácula amarronzada ao nível das $1^{\text {a }}$ e $2^{\text {a }}$ células apicais; veias ambarinas. Região ventral do corpo ferruginosa, com os esternos abdominais escurecidos. Pernas ferruginosas, com as coxas escurecidas.

Cabeça com a superfície fracamente estriada, lisa no frontoclípeo e nos lóbulos supra-antenais. Sutura coronal atingindo a base do frontoclípeo, mais marcada junto a margem superior. Espaço interocelar convexo, espaços ocelo-oculares calosos. Lóbulos supra-antenais escavados, com as margens sinuosas. Frontoclípeo piriforme, metade distal com os bordos laterais inteiros e dirigida para baixo.

Pronoto com pontuação homogênea, abaulado nas regiões adjacentes às impressões semicirculares, regularmente elevado atrás do espaço entre os processos supra-umerais, gradualmente em declive e afilado para o ápice após o ponto mais elevado e constricto ao nível do ângulo interno das tégminas. Metopídio tapezoidal, com as impressões musculares em forma de L invertido. Lóbulos pós-oculares com a superfície corrugada, sem modificações ao nível do ângulo externo dos olhos. Sulcos supra-umerais bem marcados, regiões supra-umerais com a superfície pontuada. Processos supra-umerais desenvolvidos, prismáticos, curvos na metade distal, dirigidos para os lados, inclinados para cima e com os ápices voltados para os lados e para trás; face dorsal arredondada, face posterior pontuada na metade basal e corrugada na metade distal; espaço entre eles côncavo; arestas A e P aparentes na metade distal; aresta M pronunciada na metade distal e apenas intumescida na metade basal; espaço anterior a aresta $\mathrm{M}$ normal, espaço posterior a aresta $\mathrm{M}$ escavado. Impressões semicirculares pouco distintas, áreas semicirculares planas e não impressas. Carena dorsal cortante a partir do ponto mais elevado do pronoto. Ápice não atingindo a altura da base da $3^{\mathrm{a}}$ célula apical das tégminas.

Tégminas com a veia $\mathrm{R} 1$ originando-se na $1^{\mathrm{a}}$ célula discoidal.
Genitália. Edeago plano-convexo, achatado ântero-posteriormente, notadamente na porção apical; face dorsal com uma fileira de dentículos muito tênues de cada lado nos três quintos medianos, paralelas entre si. Parâmeros contorcidos para fora na região mediana, achatados lateralmente na metade distal, dilatados no bordo inferior no quarto distal e curvados para dentro na porção apical; ápice laminar, mais esclerotinizado, com uma margem cortante no bordo superior e com a ponta dirigida para trás; pilosidade longa e homogênea distribuída ao longo da face interna do bordo superior e da face externa do bordo inferior, ao nível do quarto distal, mais densa no bordo inferior. Placas laterais do pigóforo com o dente apical proeminente, situado no ângulo anterior; dente lateral desproporcionalmente bem desenvolvido, localizado no terço superior, sinuoso e diagonalmente dirigido para baixo, com o ápice afilado e curvado também para baixo. Placa subgenital subretangular, constricta na região mediana, mais de duas vezes longa que larga basalmente.

Fêmea. Semelhante ao macho, apenas um pouco maior.

Material examinado. Brasil, Mato Grosso: Rosário Oeste, XI.1970 (sem coletor), 1 fêmea (MZUSP); Goiás: Goiânia, 9.II.1977 (N. Penny), 1 fêmea (INPA); Minas Gerais: Lassance, 9-19.XI.1919 (R.G. Harris), 1 fêmea (CU; identificado como C. uncicornis Fowler, W.D. Funkhouser det.); Corinto, VI.1979 (C. Elias), 1 fêmea (DZUP); Curvelo, 15.VI.1972 (O.H.H. Mielke), 1 fêmea (DZUP); Araxá, 22.IV.1965 (C. Elias), 1 fêmea (DZUP); Araxá, 15.V.1965 (C. \& T. Elias), 1 macho (DZUP); Araxá, 29.XI.1965 (C.T. \& C. Elias), 2 fêmeas (DZUP); Belo Horizonte, 1-6.XI.1919 (Cornell Univ. Exp.), 1 fêmea (CU; identificado como C. uncicornis Fowler, W.D. Funkhouser det.); Belo Horizonte, 15.II.1940 (Lopes), 1 macho (FIOC); Passos, IV.1961 (C. Elias), 1 fêmea (DZUP); Passos, V.1961 (C. Elias), 3 fêmeas (DZUP); Passos, 22-26.V.1962 (C. Elias), 1 macho (DZUP); Passos, 29-30.V.1962 (C. Elias), 1 fêmea (DZUP); Passos, 13-16.VI.1962 (C. Elias), 1 fêmea (DZUP); Passos, 24-29.X.1962 (C. Elias), 1 macho e 1 fêmea (DZUP); Passos, 13.XI.1962 (C. Elias), 1 macho (DZUP); Passos, 12-17.XI.1962 (C. Elias), 1 macho e 1 fêmea (DZUP); Passos, 10-15.XII.1962 (C. Elias), 1 fêmea (DZUP); Passos, 24-31.XII.1962 (C. Elias), 1 macho e 1 fêmea (DZUP); Passos, IV.1963 (C. \& T. Elias), 1 fêmea (DZUP); Passos, 1-7.V.1963 (C. Elias), 1 fêmea (DZUP); Passos, 8-14.V.1963 (C. Elias), 1 macho e 3 fêmeas (DZUP); Passos, VI.1963 (C. Elias), 1 fêmea (DZUP); Passos, 4-9.XI.1963 (C. Elias), 1 macho (DZUP); Pratápolis, 28.VIII.1963 (C. Elias), 1 macho (DZUP); Viçosa, 18.IX. 1982 (Fiuza \& Martins), 4 fêmeas (UFV); Carmo do Rio Claro, IX.1947 (Carvalho), 3 fêmeas (DZUP); Barbacena, V.1955 (F.M. Oliveira), 1 fêmea (DZUP); Varginha, I.1960 (Seabra \& Alvarenga), 1 fêmea (DZUP); Varginha, IX.1961 (M. Alvarenga), 5 machos e 10 fêmeas (DZUP); Juiz de Fora, IV.1975 (G.S. Andrade), 1 fêmea (CESJF); Juiz de Fora, XII.1981 (G.S. Andrade), 1 fêmea (CACS); Mar de Espanha, 2.XI.1908 (J.F. Zikán), 1 fêmea (FIOC); Borda da Mata, Sertãozinho, 12.I.1960 (Pereira \& Medeiros), 1 fêmea (DZUP); Itajubá, XI.1955 (R. Arlé), 1 macho (DZUP); São Paulo: Nova Granada, fazenda Guariruba, III.1960 (J. Lane), 1 fêmea 


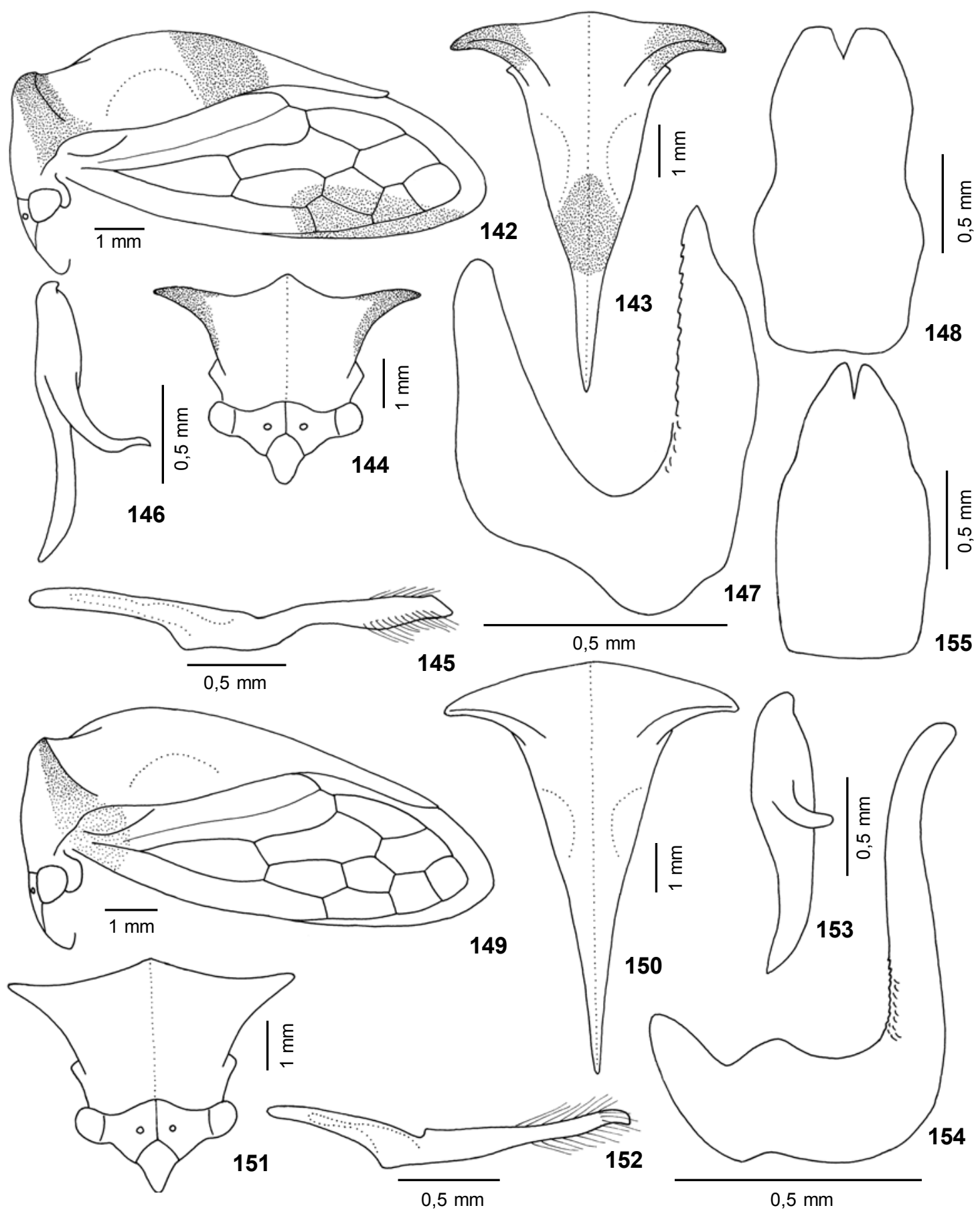

Figuras 142-155. (142-148) Ceresa paulistana: (142) cabeça, pronoto e tégmina, vista lateral; (143) pronoto, vista dorsal; (144) cabeça e pronoto, vista frontal; (145) parâmero esquerdo, vista lateral; (146) placa lateral esquerda do pigóforo, vista lateral; (147) edeago, vista lateral; (148) placa subgenital, vista ventral; (149-155) Ceresa paranaensis: (149) cabeça, pronoto e tégmina, vista lateral; (150) pronoto, vista dorsal; (151) cabeça e pronoto, vista frontal; (152) parâmero esquerdo, vista lateral; (153) placa lateral esquerda do pigóforo, vista lateral; (154) edeago, vista lateral; (155) placa subgenital, vista ventral. 
(MZUSP); Ribeirão Preto, II.1930 (R. Spitz), 2 fêmeas (MZUSP); Pirassununga, IV.1944 (D. Braz), 1 macho (MZUSP; parátipo); Leme, XII.1936 (D. Braz), 1 macho (FCNM; holótipo); [Boracéia], Estação Biológica, 1942 (sem coletor), 1 fêmea (MZUSP; parátipo); E.E. Moji-Guaçu, em Solanum erianthum, 28.V.1982 (B.C. Lopes), 1 macho (BCL); Rio Claro, 18.IX.1916 (K. Hunger), 1 sem abdome (MZUSP); Rio Claro, V.1940 (sem coletor), 1 fêmea (MZUSP); Rio Claro, I.1944 (Padre P.), 1 fêmea (MZUSP; parátipo); Piracicaba, mata da ESALQ 1.V.1962 (J. Becker), 2 fêmeas (MN); Piracicaba, 16.XII.1964 (S. Silveira Neto), 1 macho (ESALQ); Piracicaba, 540 m, X.1966 (T.J.C.), 1 macho (ESALQ); Botucatu, V.1965 (sem coletor), 1 fêmea (MZUSP); Campinas, $25 . I V .1937$ (H.F.G. Sauer), 1 fêmea (MZUSP); Campinas, Barão Geraldo, vila São João, em Byrsonima intermedia, 19.II.1982 (B.C. Lopes), 1 macho (BCL); Campinas, Barão Geraldo, vila São João, em Byrsonima intermedia, 29.II.1983 (B.C. Lopes), 1 fêmea (BCL); Campinas, fazenda Santa Elisa, em Aristolochia esperanzae, 17.III.1983 (A.B.B. Morais), 1 macho (BCL); Jundiaí, IX.1937 (D. Braz), 1 fêmea (MZUSP; alótipo); Jundiaí, IX.1937 (D. Braz), 1 fêmea (MZUSP); São Paulo, Alto da Serra, XI.1923 (sem coletor), 1 fêmea (MZUSP); Itararé, 1928 (sem coletor), 1 macho (MZUSP); Itararé, VIII.1935 (sem coletor), 1 macho (MZUSP); Itararé, 1940 (sem coletor), 1 fêmea (MZUSP); Rio de Janeiro: Paraíba do Sul, 1949 (J.C.M. Carvalho), 1 fêmea (DZUP); Macaé, Barra do Saná, I.1957 (Alceu), 2 machos (MN); estrada Rio de Janeiro-São Paulo, km 54, $10 . I I .1942$ (ilegível), 1 macho (MZUSP).

Distribuição geográfica. BRASIL: Minas Gerais e São Paulo (Remes-Lenicov 1976), Mato Grosso, Goiás e Rio de Janeiro.

Localidade-tipo. Brasil, São Paulo: Leme.

Notas sobre os tipos. Segundo a descrição original o holótipo macho estaria depositado no IB, mas foi localizado na FCNM. O exemplar está em razoável estado de conservação, microalfinetado, espetado em suporte de pita, e com o abdome dissecado. A tégmina esquerda está com o limbo rasgado entre as $3^{\mathrm{a}}$ e $4^{\mathrm{a}}$ células apicais, falta a porção apical da tégmina direita a partir do meio da $3^{\text {a }}$ célula apical, e faltam também trocânter, fêmur, tíbia e tarso II esquerdos, fêmur, tíbia e tarso III esquerdos e trocânter, fêmur, tíbia e tarso II e III direitos. Ainda segundo a descrição original, o alótipo fêmea, um parátipo macho e três parátipos fêmeas estariam depositados também no IB. Cabe ressaltar que foram localizados o alótipo, o parátipo macho e dois parátipos fêmeas no MZUSP, mas o repositório do outro parátipo fêmea é incógnito.

Plantas hospedeiras. Solanum erianthum e Byrsonima intermedia (observações de B.C. Lopes) e Aristolochia esperanzae (observação de A.B.B. Morais).

Comentários. Foram observadas variações na coloração, principalmente na região ventral do corpo, no padrão de pontuação do pronoto, no aspecto do espaço entre os processos supra-umerais e na aparência das impressões e áreas semicirculares.

Difere das demais espécies notadamente pelo padrão de coloração.

\section{Ceresa paranaensis Remes-Lenicov, 1976 Figs 149-155}

Ceresa paranaensis Remes-Lenicov, 1976: 47, lám. II, figs 10 a 18; McKamey, 1998: 245 (cat.).

Medidas. Macho (parátipo)/fêmea (alótipo). Largura da cabeça: 3,12/3,44; comprimento da cabeça: 1,56/1,72; distância entre os ângulos umerais: 3,20/3,52; distância entre os ápices dos processos supra-umerais: 5,17/5,83; comprimento do pronoto: 8,17/9,00; comprimento total: 9,50/10,17.

Descrição. Macho. Coloração geral ferruginosa. Face ventral e porção apical da face posterior dos processos supraumerais acastanhadas; aresta $\mathrm{M}$ amarelada; ápices dos processos supra-umerais e do pronoto negros. Tégminas ambarinas, acastanhadas na base; veias ambarinas. Região ventral do corpo ferruginosa, com as pleuras torácicas acastanhadas. Pernas ferruginosas, com as coxas acastanhadas.

Cabeça com a superfície fracamente estriada, lisa no frontoclípeo e nos lóbulos supra-antenais. Sutura coronal atingindo a base do frontoclípeo, mais marcada junto a margem superior. Espaço interocelar convexo, espaços ocelo-oculares calosos. Lóbulos supra-antenais escavados, com as margens sinuosas. Frontoclípeo sublosângico, metade distal com os bordos laterais chanfrados e dirigida para baixo.

Pronoto com pontuação homogênea, não abaulado nas regiões adjacentes às impressões semicirculares, regularmente elevado atrás do espaço entre os processos supra-umerais, gradualmente em declive e afilado para o ápice após o ponto mais elevado e não constricto ao nível do ângulo interno das tégminas. Metopídio trapezoidal, com as impressões musculares em forma de $\mathrm{V}$ invertido. Lóbulos pós-oculares com a superfície lisa, sem modificações ao nível do ângulo externo dos olhos. Sulcos supra-umerais bem marcados, regiões supraumerais com a superfície pontuada. Processos supra-umerais desenvolvidos, prismáticos, curvos na metade distal, dirigidos para os lados, inclinados para cima e com os ápices voltados para os lados e para trás; face dorsal arredondada, face posterior pontuada na metade basal e corrugada na metade distal; espaço entre eles plano; arestas A e P aparentes na metade distal; aresta $\mathrm{M}$ pronunciada como um intumescimento em toda a sua extensão; espaço anterior a aresta $\mathrm{M}$ intumescido, espaço posterior a aresta $\mathrm{M}$ escavado. Impressões semicirculares pouco distintas, áreas semicirculares planas e não impressas. Carena dorsal cortante a partir do ponto mais elevado do pronoto. Ápice atingindo a altura da base da $3^{\text {a }}$ célula apical das tégminas. Tégminas com a veia $\mathrm{R} 1$ originando-se na $1^{\mathrm{a}}$ célula discoidal.

Genitália. Edeago subcilíndrico na metade basal e achatado lateralmente na metade distal, com o terço apical curvado para trás; face dorsal com dentículos muito tênues distribuídos em mosaico no terço basal. Parâmeros subcilíndricos, curvados para dentro no terço distal e achatados lateralmente na porção apical; ápice laminar, mais esclerotinizado, com mar- 
gens cortantes em ambos os bordos e com uma ponta dirigida para baixo; pilosidade longa e homogênea distribuída nos bordos superior e inferior, ao nível do terço distal. Placas laterais do pigóforo com o dente apical intumescido, situado no ângulo central; dente lateral bem desenvolvido, localizado no terço mediano, curvado para baixo e para trás, com o ápice arredondado. Placa subgenital glandiforme, mais de duas vezes longa que larga basalmente.

Fêmea. Semelhante ao macho, apenas um pouco maior. Material examinado. BRASIL, Minas Gerais: serra do Caraça, III.1963 (F. Werner, U. Martins \& L. Silva), 2 fêmeas (MZUSP); serra do Caraça, Santa Bárbara, I.1971 (F.M. Oliveira), 1 fêmea (DZUP); serra do Caraça, Santa Bárbara, III.1971 (F.M. Oliveira), 1 fêmea (DZUP); Juiz de Fora, V.1975 (G.S. Andrade), 1 fêmea (CESJF); Poços de Caldas, morro do Ferro, 2.VII.1967 (J. Becker, O. Roppa \& O. Leoncini), 1 macho (MN); Poços de Caldas, morro Santa Rosália, 5.VII.1971 (J. Becker), 1 fêmea (MN); Passa Quatro, 915 m, 19.I.1923 (J. Zikán), 1 fêmea (FIOC); Itajubá, 8.I.1961 (Herbert), 1 fêmea (MN); Espírito Santo: Barra de São Francisco, XII.1947 (Ruschi), 1 fêmea (MZUSP); São Paulo: Itapura, 1934 (sem coletor), 1 fêmea (MZUSP); serra da Bocaina, São José do Barreiro, 1680 m, III.1973 (F.M. Oliveira), 1 macho (DZUP); Campos do Jordão, VIII.1949 (J. Lane), 1 macho (MZUSP); Campinas, VII.1936 (D. Braz), 1 fêmea (MZUSP; parátipo); Campinas, VII.1936 (D. Braz), 2 fêmeas (IB); Campinas, 4.IV.1938 (H.F.G. Sauer), 1 fêmea (MZUSP); Campinas, I.1940 (sem coletor), 1 fêmea (MZUSP); Campinas, I.1951 (sem coletor), 1 fêmea (MZUSP); São José dos Campos, II.1935 (D.B.), 1 macho (MZUSP); Barueri, 9.II.1955 (K. Lenko), 1 fêmea (MZUSP); Barueri, 30.VIII.1955 (K. Lenko), 1 fêmea (MZUSP); São Paulo, X.1935 (E. Sch.), 1 fêmea (IB); São Paulo, VII.1936 (D. Braz), 1 fêmea (IB); São Paulo, VII.1936 (J.P.F.), 1 fêmea (MZUSP); São Paulo, V.1937 (E. Schw.), 1 fêmea (MZUSP); São Paulo, VII.1937 (E. Schuz.), 1 fêmea (MZUSP; parátipo); São Paulo, VII.1937 (E. Schw.), 4 fêmeas (MZUSP); São Paulo, V.1938 (Guerin), 1 fêmea (MZUSP; parátipo); São Paulo, VII.1941 (D. Braz), 1 macho (MZUSP); São Paulo, Mata do Governo, XI.1925 (sem coletor), 1 macho (MZUSP); São Paulo, M. Governo, 1939 (sem coletor), 1 fêmea (MZUSP); São Paulo, Parque Jabaquara, IX.1931 (sem coletor), 2 machos (MZUSP); São Paulo, Parque Jabaquara, III.1937 (Schw.), 2 fêmeas (MZUSP); São Paulo, Jabaquara, VI.1937 (Schw.), 1 fêmea (MZUSP); São Paulo, Parque Jabaquara, II.1948 (Margarida), 1 macho (MZUSP); São Paulo, Cantareira, VI.1937 (Schw.), 1 fêmea (MZUSP); São Paulo, Cantareira, VII.1937 (Schw.), 3 fêmeas (MZUSP); Itararé, VIII.1935 (sem coletor), 2 fêmeas (MZUSP); Itararé, 1940 (J.P.F.), 1 fêmea (MZUSP); Sem indicação de Estado: serra da Bocaina, I.1969 (Alvarenga), 1 macho (DZUP); serra da Bocaina, XI.1970 (M. Alvarenga), 1 fêmea (DZUP); Rio de Janeiro: Nova Friburgo, Muri, 1-15.I.1978 (Gred \& Guimarães), 1 macho e 1 fêmea (MZUSP); Nova Friburgo, Muri, XII.1980 (Gred \& Guimarães), 1 macho e 1 fêmea (MZUSP); Teresópolis, 25.I.1940 (Lopes), 2 fêmeas (FIOC); Teresópolis, Parque Nacional da Serra dos Órgãos,
29.VIII.1957 (J. Becker), 1 fêmea (MN); Parque Nacional do Itatiaia, I.1958 (D. Zajciw), 1 macho (FIOC); Itatiaia, $700 \mathrm{~m}$, 5.I.1925 (J.F. Zikán), 1 fêmea (FIOC); Itatiaia, 700 m, 17.II.1927 (J.F. Zikán), 1 fêmea (FIOC); Itatiaia, km 7, 25.I.1937 (J.F. Zikán), 1 fêmea (FIOC); Itatiaia, 700 m, 13.X.1942 (W. Zikán), 1 fêmea (MN); Itatiaia, 20.XII.1946 (J.F. Zikán), 1 fêmea (FIOC); Itatiaia, 1300 m, 3-8.II.1951 (Travassos \& Albuquerque), 1 macho (FIOC); Itatiaia, 850 m, I.1955 (U. Barth), 1 fêmea (MN); Itatiaia, 800 m, VII.1956 (U. Barth), 3 fêmeas (MN); Itatiaia, 2000 m, I.1957 (U. Barth), 1 macho e 1 fêmea (MN); Itatiaia, 1000 m, em Urticaceae, 8.IX.1983 (B.C. Lopes), 1 fêmea (BCL); Itatiaia, Maromba, 29.XII.1952 (C. Leite, Seabra \& Zikán), 1 fêmea (MN); Itatiaia, Maromba, 1200 m, 26.XII.1953 (Seabra \& Alvarenga), 1 macho (DZUP); Itatiaia, Parque das Agulhas Negras, 1950-2200 m, 18.XII.1966 (H. Reichardt), 1 fêmea (MZUSP); Rio de Janeiro, floresta da Tijuca, 25.X.1982 (C.A.C. Seabra), 1 macho (CACS); Rio de Janeiro, represa Rio Grande, 10.II.1966 (F.M. Oliveira), 1 sem abdome (DZUP); Rio de Janeiro, represa Rio Grande, 2.III.1967 (M. Oliveira), 1 fêmea (DZUP; identificado como C. axillaris (Germar), A.M. Sakakibara det.); Rio de Janeiro, represa Rio Grande, 20.V.1967 (F.M. Oliveira), 2 fêmeas (DZUP; identificado como C. axillaris (Germar), A.M. Sakakibara det.); Rio de Janeiro, represa Rio Grande, 15.X.1967 (F. Oliveira), 1 macho e 1 fêmea (DZUP); Rio de Janeiro, represa Rio Grande, 18.X.1967 (F. Oliveira), 1 fêmea (DZUP); Rio de Janeiro, represa Rio Grande, IV.1972 (F.M. Oliveira), 1 fêmea (DZUP); Rio de Janeiro, represa Rio Grande, IX.1972 (F.M. Oliveira), 2 machos (DZUP); Itacuruça, 1950 (J.C.M. Carvalho), 2 fêmeas (DZUP; identificado como C. axillaris (Germar), A.M. Sakakibara det.); Paraná: Campo Mourão, 1954 (sem coletor), 1 macho (FCNM; holótipo); Campo Mourão, 1954 (sem coletor), 2 fêmeas (MZUSP; alótipo e parátipo); Campo Mourão, 1954 (J.P.F.), 1 macho (MZUSP); Castro, 1948 (sem coletor), 1 macho e 1 fêmea (MZUSP); Ponta Grossa, X.1937 (J.P. Machado), 1 macho (MZUSP); Ponta Grossa, 11.XI.1937 (J.P. Machado), 1 fêmea (MZUSP); Ponta Grossa, Lageado, III.1971 (sem coletor), 1 macho (CESJF); Quatro Barras, 6.II.1966 (J.S. Moure), 1 fêmea (DZUP); Curitiba, XII.1939 (J. Leprevost), 1 fêmea (MZUSP); Curitiba, 15-27.XI.1983 (E.C. Costa), 1 fêmea (DZUP); Curitiba, Barigui, 20.III.1962 (R. Lange), 1 fêmea (RBL); Curitiba, Barigui, 8.IV.1962 (R. Lange), 2 fêmeas (RBL); Curitiba, Barigui, 20.IV.1962 (R. Lange), 1 fêmea (RBL); Curitiba, Cascatinha, 5.IV.1974 (O.H.H. Mielke), 1 macho (DZUP); Morretes, 29.XI.1970 (V.O. Becker), 1 macho (DZUP); São José dos Pinhais, BR 277, km 30, IV.1986 (H.J. Barbosa), 1 macho (DZUP); Lapa, III.1988 (G.S. Andrade), 1 fêmea (DZUP); Tijucas do Sul, 27.II.1986 (O.H.H. Mielke \& J. C. Callaghan), 1 fêmea (DZUP); Santa Catarina: São Bento do Sul, Rio Vermelho, 21.II.1974 (Sakakibara \& Mielke), 1 fêmea (DZUP); São Bento do Sul, Rio Vermelho, 850 m, 17.III.1974 (Rank), 1 macho e 2 fêmeas (DZUP); São Bento do Sul, Rio Vermelho, $850 \mathrm{~m}$, 24.III.1974 (Rank), 4 fêmeas (DZUP); São Bento do Sul, Rio Vermelho, 850 m, 1.IV.1974 (Rank), 1 fêmea (DZUP); Rio Vermelho, sem data (sem coletor), 2 fêmeas (MZUSP; parátipos); Santa

Revista Brasileira de Zoologia 21 (4): 671-738, dezembro 2004 
Cecília, Campo Alto, km 227, 12.II.1973 (Sakakibara \& Mielke), 2 fêmeas (DZUP); Bom Retiro, I.1929 (sem coletor), 1 macho (MZUSP); Rio Grande do Sul: Porto Alegre, vila Oliva, 11.II.1948 (sem coletor), 1 fêmea (MA); Porto Alegre, vila Oliva, 8.II.1949 (sem coletor), 1 macho (MA); Porto Alegre, vila Oliva, I.1961 (sem coletor), 1 macho (MA). Sem indicação de localidade, sem data (sem coletor), 1 macho e 1 fêmea (MZUSP; parátipos!).

Distribuição geográfica. BRASIL: São Paulo, Rio de Janeiro, Paraná e Santa Catarina (Remes-Lenicov 1976), Minas Gerais, Espírito Santo e Rio Grande do Sul.

Localidade-tipo. Brasil, Paraná: Campo Mourão.

Notas sobre os tipos. Segundo a descrição original o holótipo macho estaria depositado no IB, mas foi localizado na FCNM. O exemplar está em péssimo estado de conservação, microalfinetado, espetado em suporte de cortiça, e com o abdome dissecado. A porção mediana do processo supra-umeral esquerdo está rachada, faltam o processo pronotal posterior, um pedaço do limbo da tégmina esquerda ao nível de seu ângulo interno e a porção distal de ambas as tégminas a partir da altura da base da $3^{\text {a }}$ célula apical. Ainda segundo a descrição original, o alótipo fêmea, um parátipo macho e onze parátipos fêmeas estariam depositados também no IB. Cabe ressaltar que foram localizados o alótipo e seis parátipos fêmeas no MZUSP, mas o repositório do parátipo macho e dos outros parátipos fêmeas é incógnito. Foram encontrados também no MZUSP um macho e uma fêmea não citados na descrição original, sem nenhuma etiqueta de dados apensa aos alfinetes, mas cada qual com etiqueta de parátipo manuscrita pela autora!

Planta hospedeira. Desconhecida.

Comentários. Foram observadas variações na coloração, principalmente na aresta $\mathrm{M}$, nas extremidades do pronoto e na região ventral do corpo, no padrão de pontuação do pronoto, na extensão e inclinação dos processos supra-umerais e que alguns exemplares apresentam uma mácula acastanhada ao nível da $1^{\text {a }}$ célula apical das tégminas.

Difere das demais espécies notadamente por apresentar a aresta $\mathrm{M}$ intumescida em toda a sua extensão.

\section{Ceresa malina (Germar, 1835) Figs 156-162}

Smilia malina Germar, 1835: 236.

Ceresa malina; Metcalf \& Wade, 1965: 864 (cat.); Remes-Lenicov, 1973: 91, lám. XIII e XIV, figs 94 a 102 (rdescr., gen. masc. fem.), 97 e 102 (not.); Kopp \& Yonke, 1979: 24 (list.); McKamey, 1998: 245 (cat.).

Medidas. Macho/fêmea. Largura da cabeça: 3,28/3,36; comprimento da cabeça: 1,64/1,68; distância entre os ângulos umerais: 3,48/3,56; distância entre os ápices dos processos supra-umerais: 5,83/6,00; comprimento do pronoto: $8,50 / 7,92$; comprimento total: 9,67/9,00.

Descrição. Macho. Coloração geral amarelo-esverdeada, com máculas esbranquiçadas. Porção apical da face dorsal, face ventral e porção apical da face posterior dos processos supraumerais, regiões supra-umerais, carena dorsal a partir do ponto mais elevado do pronoto e processo pronotal posterior, acastanhados; faixa nos lados do metopídio e metade basal da aresta M esbranquiçadas; ápices dos processos supra-umerais e do pronoto negros. Tégminas e veias hialinas. Região ventral do corpo amarelada, com as pleuras torácicas e esternos abdominais com máculas enegrecidas. Pernas amareladas.

Cabeça com a superfície estriada, corrugada no frontoclípeo e nos lóbulos supra-antenais. Sutura coronal atingindo a base do frontoclípeo, mais marcada junto a margem superior. Espaço interocelar convexo, espaços ocelo-oculares planos. Lóbulos supra-antenais planos, com as margens sinuosas. Frontoclípeo sublosângico, metade distal com os bordos laterais chanfrados e dirigida para baixo.

Pronoto com pontuação homogênea, não abaulado nas regiões adjacentes às impressões semicirculares, regularmente elevado atrás do espaço entre os processos supra-umerais, gradualmente em declive e afilado para o ápice após o ponto mais elevado e constricto ao nível do ângulo interno das tégminas. Metopídio trapezoidal, com as impressões musculares em forma de L invertido. Lóbulos pós-oculares com a superfície pontuada, sulcados ao nível do ângulo externo dos olhos. Sulcos supra-umerais bem marcados, regiões supra-umerais com a superfície pontuada. Processos supra-umerais desenvolvidos, prismáticos, retos na metade distal, dirigidos para os lados, inclinados para baixo e com os ápices voltados para os lados; face dorsal arredondada, face posterior pontuada na metade basal e corrugada na metade distal; espaço entre eles plano; arestas A e P aparentes na metade distal; aresta $\mathrm{M}$ pronunciada na metade distal e apenas intumescida na metade basal; espaço anterior a aresta $\mathrm{M}$ normal, espaço posterior a aresta $\mathrm{M}$ escavado. Impressões semicirculares pouco distintas, áreas semicirculares planas e não impressas. Carena dorsal cortante a partir do ponto mais elevado do pronoto. Ápice atingindo a altura da base da $3^{\mathrm{a}}$ célula apical das tégminas.

Tégminas com a veia $\mathrm{R} 1$ originando-se na $1^{\mathrm{a}}$ célula discoidal.

Genitália. Edeago subcilíndrico, afilado distalmente; face dorsal com uma fileira dupla e irregular de dentículos de cada lado nos dois quartos medianos, algo em mosaico na porção basal. Parâmeros achatados lateralmente na metade distal, curvados para dentro e gradualmente afilados para o ápice no terço distal, e abruptamente alargados na porção apical; ápice laminar, em forma de machado, mais esclerotinizado, com uma ponta dirigida para baixo; pilosidade longa e homogênea, imbricada para dentro, distribuída nos bordos superior e inferior, ao nível do quarto distal. Placas laterais do pigóforo com o dente apical proeminente, situado no ângulo central; dente lateral bem desenvolvido, localizado no terço superior, diagonalmente dirigido para baixo e com o ápice arredondado. Placa subgenital dilatada na região mediana, mais de duas vezes longa que larga basalmente. 
Fêmea. Semelhante ao macho, apenas um pouco maior. Material examinado. Brasil, Minas Gerais: Passos, 1015.XII.1962 (C. Elias), 2 machos (DZUP); Barbacena, X.1955 (sem coletor), 1 macho (FIOC); Poços de Caldas, campo do Saco, 10.I.1967 (J. Becker, O. Roppa \& O. Leoncini), 2 fêmeas (MN); Poços de Caldas, morro do Ferro, 13.I.1967 (J. Becker e O. Leoncini), 1 fêmea (MN); Poços de Caldas, morro São Domingos, 16.I.1968 (J. Becker, O. Roppa \& O. Leoncini), 1 fêmea (MN); Borda da Mata, Sertãozinho, 12.I.1960 (Pereira \& Medeiros), 1 macho (MZUSP); Passa Quatro, 915 m, 14.XII.1922 (J. Zikán), 1 fêmea (FIOC); Passa Quatro, XII.1972 (F.M. Oliveira), 3 machos e 15 fêmeas (DZUP); Espírito Santo: Baixo Guandu, 23-31.XII.1970 (C. Elias), 1 fêmea (DZUP); São Paulo: Leme, XII.1936 (D. Braz), 1 fêmea (IB); Boracéia, 8.III.1948 (D. Braz), 1 fêmea (MZUSP); Campos do Jordão, 17-29.I.1977 (A. Scivittaro), 1 fêmea (MZUSP); São José dos Campos, I.1937 (H.S. Lopes), 1 macho (MZUSP); Mairiporã, 4-13.I.1967 (C. Costa), 8 machos e 13 fêmeas (MZUSP); Barueri, XI.1954 (K. Lenko), 1 macho (CACS); São Paulo, 10.I.1933 (M.C. Leite), 1 fêmea (MZUSP); São Paulo, 20.II.1933 (M.C. Leite), 2 fêmeas (IB); São Paulo, 2.I.1965 (F. Wiendl), 1 macho (ESALQ); São Paulo, Pádua Salles, X.1936 (sem coletor), 1 fêmea (MZUSP); São Paulo, Parque Jabaquara, IX.1931 (sem coletor), 1 fêmea (MZUSP); São Paulo, Santo Amaro, I.1936 (J. Lane), 1 fêmea (MZUSP); São Paulo, Santo Amaro, XII.1941 (J. Lane), 1 macho (MZUSP); São Paulo, Santo Amaro, XII.1962 (J. Lane), 2 fêmeas (MZUSP); São Paulo, Penha, VII.1957 (J. Thom...), 1 fêmea (MZUSP); Salesópolis, Estação Biológica da Boracéia, 14-18.XI.1973 (Exp. Mus. Zool.), 1 macho (MZUSP); Paraná: Tibaji, 6.XII.1965 (V. Graf \& L. Azevedo), 1 fêmea (DZUP); Ponta Grossa, XII.1938 (Camargo), 2 fêmeas (DZUP); Ponta Grossa, Pedreira, II.1942 (sem coletor), 2 machos (DZUP); Guaraúna, 3.XII.1938 (Camargo \& Andrade), 1 fêmea (MZUSP); Curitiba, XII.1937 (sem coletor), 2 machos e 2 fêmeas (MZUSP); Curitiba, 19.I.1968 (A. Sakakibara), 1 macho e 6 fêmeas (DZUP); Curitiba, 10.I.1969 (Sakakibara), 2 machos e 7 fêmeas (DZUP); Curitiba, 15.I.1971 (A.M. Sakakibara), 1 macho e 1 fêmea (DZUP); São José dos Pinhais, 22.XI.1985 (Cavichioli), 1 fêmea (DZUP); Lapa, 22.XI.1970 (Moure), 1 macho (DZUP); Campo do Tenente, 8.XII.1965 (Moure \& Marinoni), 1 fêmea (DZUP); Rincão, 25.II.1969 (Sakakibara), 14 fêmeas (DZUP); Santa Catarina: Nova Teutônia, $27^{\circ} 11^{\prime} \mathrm{B}, 5^{\circ} 23^{\prime} \mathrm{L}, 300-500 \mathrm{~m}$, XI.1974 (F. Plaumann), 1 macho e 2 fêmeas (DZUP); Nova Teutônia, $27^{\circ} 11^{\prime} \mathrm{B}, 52^{\circ} 23^{\prime} \mathrm{L}$, 300-500 m, XII.1980 (F. Plaumann), 1 fêmea (DZUP); Lajes, Parque Pedra Branca, 13.II.1973 (Sakakibara \& Mielke), 4 fêmeas (DZUP); Rio Grande do Sul: Barão de Cotegipe, 3.I.1966 (F. Giacomel), 1 fêmea (DZUP); Barão de Cotegipe, 21.I.1967 (F. Giacomel), 1 fêmea (DZUP); Santo Augusto, XII.1975 (O. Roppa), 1 macho e 13 fêmeas (DZUP); São Leopoldo, sem data (sem coletor), 1 fêmea (MA); Porto Alegre, 8.XI.1933 (sem coletor), 1 macho (MA). CHILE, Santiago: (?) Santiago, 1941 (sem coletor), 1 macho (MZUSP). ParaguaI, Cagguazú: Coronel Pirareta, 25.XII. 1971 (L.E. Peña), 1 fêmea (UPR); Central: San Lorenzo, I.1962 (Sakagami \& Laroca), 1 macho (DZUP). Argentina, Misiones:
Loreto, sem data (A.A. Oglobin), 1 macho (MZUSP); Tucumán: sem indicação de localidade, 10.XI.1944 (Golbach), 1 macho (FML; identificado como C. axillaris (Germar), A.M.M. RemesLenicov det.); Corrientes: San Roque, II.1920 (Bosq), 1 macho (MZUSP); (?) Corrientes, I.1921 (de Carlo), 1 fêmea (MZUSP); Santa Fe: Candioti, 21.XI.1939 (Birabén \& Bezzi), 1 macho (FCNM); Córdoba: Balnearia, 2.III.1971 (Fritz), 1 fêmea (DZUP); Marcos Juárez, 30.I.1981 (Bordón), 1 fêmea (CB); Agua de Oro, I.1940 (J.A. de Carlo), 3 fêmas (MZUSP); Punilla, I.1943 (? Villafañe), 1 fêmea (FML); Buenos Aires: San Isidro, XII.1961 (A. Martinez), 1 fêmea (MZUSP); (?) Buenos Aires, sem data (sem coletor), 1 fêmea (MZUSP; identificado como C. brunnicornis (Germar), A.M.M. Remes-Lenicov det.); (?) Buenos Aires, sem data (Stål), 1 sem abdome e 1 fêmea (MZUSP); Moreno, X.1970 (M.A. Fritz), 3 machos (DZUP); Los Acantilados, 22.XII.1968 (De Santis \& Millán), 3 fêmeas (FCNM).

Distribuição geográfica. Brasil: Minas Gerais, Espírito Santo, São Paulo, Paraná, Santa Catarina e Rio Grande do Sul. Bolívia: La Paz (Remes-Lenicov 1973). Chile: Santiago. Paraguai: Caaguazú e Central. Argentina: Buenos Aires (Germar 1835), Chaco, Misiones, Tucumán, Corrientes, Santa Fe, Córdoba e Entre Ríos (Remes-Lenicov 1973). 1835).

Localidade-tipo. "Habitat in Buenos-Ayres." (Germar

Notas sobre o(s) tipo(s). Veja comentários apresentados sob este item para C. axillaris (Germar).

Plantas hospedeiras. "...sobre alfalfa (Medicago sativa L.) y papa (Solanum tuberosum L.)." (Remes-Lenicov 1973).

Comentários. Esta espécie foi interpretada em consonância com Remes-Lenicov (1973), cuja redescrição e ilustrações se ajustam muito bem a descrição original.

Não obstante, uma definição futura do tipo de Smilia malina Germar poderia alterar a interpretação adotada para a espécie.

Foram observadas variações na coloração, principalmente na região ventral do corpo, na inclinação e na direção dos ápices dos processos supra-umerais, e no grau de extensão do ápice do pronoto com relação a altura da base da $3^{\text {a }}$ célula apical das tégminas.

Difere das demais espécies notadamente pelo padrão de coloração.

\section{Ceresa plaumanni Sakakibara, 1977 Figs 163-169}

Ceresa plaumanni Sakakibara, 1977: 31, figs 1 a 7; McKamey, 1998: 246 (cat.).

Ceresa concinna; Remes-Lenicov, 1973: 100, lám. XVII, figs 119 a 127 (rdescr., gen. masc. fem.), 93 (not.), non C. concinna Fowler, 1895.

Medidas. Macho (parátipo)/fêmea (holótipo). Largura da cabeça: 3,00/3,08; comprimento da cabeça: 1,50/1,54; distância entre os ângulos umerais: 3,16/3,16; distância entre os ápi- 
ces dos processos supra-umerais: 4,84/4,76; comprimento do pronoto: 7,00/7,50; comprimento total: 8,67/8,75.

Descrição. Macho. Coloração geral amarelo-ferruginosa, mais escurecida no fundo das pontuações, mais clara na cabeça, no metopídio e no espaço entre os processos supra-umerais, com máculas amareladas nas regiões adjacentes às impressões semicirculares e nas áreas semicirculares. Faces ventral e posterior dos processos supra-umerais e regiões supra-umerais acastanhadas; metade basal da aresta $\mathrm{M}$ e uma mancha pré-apical no processo pronotal posterior amareladas; porção apical dos processos supra-umerais e ápice do pronoto negros. Tégminas ambarinas, com uma mácula acastanhada ao nível da $2^{\mathrm{a}}$ célula apical; veias ambarinas. Região ventral do corpo e pernas amareladas.

Cabeça com a superfície estriada, corrugada no frontoclípeo e nos lóbulos supra-antenais. Sutura coronal atingindo a base do frontoclípeo. Espaço interocelar convexo, espaços ocelo-oculares deprimidos. Lóbulos supra-antenais escavados, com as margens sinuosas. Frontoclípeo sublosângico, metade distal com os bordos laterais chanfrados e dirigida para baixo.

Pronoto com pontuação homogênea, abaulado nas regiões adjacentes às impressões semicirculares, regularmente elevado atrás do espaço entre os processos supra-umerais, gradualmente em declive e afilado para o ápice após o ponto mais elevado e constricto ao nível do ângulo interno das tégminas. Metopídio trapezoidal, com as impressões musculares em forma de L invertido. Lóbulos pós-oculares com a superfície corrugada, sem modificações ao nível do ângulo externo dos olhos. Sulcos supra-umerais bem marcados, regiões supraumerais com a superfície pontuada. Processos supra-umerais desenvolvidos, prismáticos, retos na metade distal, dirigidos para os lados, sem inclinação e com os ápices voltados para os lados; face dorsal arredondada, face posterior pontuada na metade basal e corrugada na metade distal; espaço entre eles plano; arestas A e P aparentes na metade distal; aresta M pronunciada na metade distal e apenas intumescida na metade basal; espaço anterior a aresta $\mathrm{M}$ normal, espaço posterior a aresta $\mathrm{M}$ escavado. Impressões semicirculares pouco distintas, áreas semicirculares planas e não impressas. Carena dorsal cortante a partir do ponto mais elevado do pronoto. Ápice atingindo a altura da base da $3^{\text {a }}$ célula apical das tégminas. discoidal.

Tégminas com a veia $\mathrm{R} 1$ originando-se na $1^{\mathrm{a}}$ célula

Genitália. Edeago subcilíndrico, afilado distalmente; face dorsal com uma fileira dupla e irregular de dentículos de cada lado, algo em mosaico na porção basal. Parâmeros achatados lateralmente na metade distal, curvados para cima e para dentro no terço distal, e abruptamente constrictos na porção préapical; ápice laminar, em forma de machado, mais esclerotinizado, com um dentículo conspícuo no ângulo póstero-superior; pilosidade longa e homogênea, imbricada para dentro, distribuída nos bordos superior e inferior, ao ní- vel do quarto distal, mais densa no bordo inferior. Placas laterais do pigóforo com o dente apical proeminente, situado no ângulo central; dente lateral bem desenvolvido, localizado no terço mediano, diagonalmente dirigido para baixo, com o ápice agudo e discretamente curvado também para baixo. Placa subgenital quase duas vezes mais longa que larga basalmente, estreitando-se após a região mediana.

Fêmea. Semelhante ao macho, apenas um pouco maior. Material examinado. Brasil, Minas Gerais: Poços de Caldas, morro São Domingos, 17.XII.1965 (O. Leoncini), 1 macho e 1 fêmea $(\mathrm{MN})$; Poços de Caldas, morro São Domingos, 16.XII.1967 (J. Becker, O. Roppa \& O. Leoncini), 1 fêmea (MN); Poços de Caldas, morro São Domingos, 4.II.1968 (J. Becker, O. Roppa \& O. Leoncini), 1 fêmea (MN); Poços de Caldas, morro do Ferro, 13.I.1967 (J. Becker \& O. Leoncini), 1 fêmea (MN); Poços de Caldas, morro do Ferro, 28.I.1968 (J. Becker \& O. Leoncini), 1 fêmea (MN); Poços de Caldas, Retiro Branco, 1.I.1968 (J. Becker \& O. Leoncini), 1 fêmea $(\mathrm{MN})$; São Paulo: Itararé, XII.1935 (E. Sch.), 1 fêmea (MZUSP; identificado como C. concinna Fowler, A.M.M. Remes-Lenicov det.); Paraná: Curitiba, 24.XI.1937 (Claret), 1 macho (MZUSP); Santa Catarina: Santa Cecília, 8.XII.1983 (Exc. Dep. Zool. UFPR), 1 macho e 1 fêmea (DZUP); Nova Teutônia, 16.IX.1952 (F. Plaumann), 1 fêmea (DZUP; holótipo); Nova Teutônia, 26.IX.1952 (F. Plaumann), 1 macho (DZUP; parátipo); Nova Teutônia, XI.1966 (F. Plaumann), 1 macho (MZUSP); Nova Teutônia, XII.1966 (F. Plaumann), 1

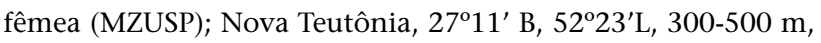
XI.1973 (F. Plaumann), 1 macho e 1 fêmea (DZUP; parátipos); Nova Teutônia, $27^{\circ} 11^{\prime} \mathrm{B}, 52^{\circ} 23^{\prime} \mathrm{L}, 300-500$ m, XI.1980 (F. Plaumann), 1 macho e 6 fêmeas (DZUP); Nova Teutônia, $27^{\circ} 11^{\prime} \mathrm{B}$, $52^{\circ} 23^{\prime} \mathrm{L}, 300-500$ m, XIII.1980 (F. Plaumann), 2 machos e 3 fêmeas (DZUP); Nova Teutônia, $27^{\circ} 11^{\prime} \mathrm{B}, 52^{\circ} 23^{\prime} \mathrm{L}, 300-500 \mathrm{~m}$, II.1981 (F. Plaumann), 2 fêmeas (DZUP); Anita Garibaldi, V.1954 (sem coletor), 1 macho (MZUSP; identificado como C. concinna Fowler, A.M.M. Remes-Lenicov det.); Rio Grande do Sul: Santo Augusto, XII.1975 (O. Roppa), 1 fêmea (DZUP); Cruz Alta, sem data (sem coletor), 1 fêmea (LU); Sobradinho, 8.II.1948 (J. Becker), 1 fêmea (MN); São Francisco de Paula, I.1936 (sem coletor), 1 fêmea (MA); São Francisco de Paula, II.1936 (sem coletor), 1 fêmea (MA); São Francisco de Paula, I.1937 (sem coletor), 1 macho e 3 fêmeas (MA); São Francisco de Paula, I.1958 (sem coletor), 1 fêmea (MA); Pareci Novo, III.1932 (sem coletor), 1 macho (MA); São Leopoldo, I.1938 (sem coletor), 1 fêmea (MA); Porto Alegre, vila Oliva, 8.II.1949 (sem coletor), 2 fêmeas (MA); Porto Alegre, vila Oliva, 19.II.1949 (sem coletor), 1 fêmea (MA); Porto Alegre, vila Oliva, 15.II.1951 (sem coletor), 1 fêmea (MA); Porto Alegre, vila Oliva, III.1956 (sem coletor), 1 macho (MA); Itapiranga, II.1934 (sem coletor), 1 fêmea (MA); Itapiranga, II.1953 (sem coletor), 1 fêmea (MA); Itapiranga, I.1954 (sem coletor), 1 macho e 1 fêmea (MA); Palmeira, I.1929 (sem coletor), 2 fêmeas (MA). Argentina, Misiones: San Pedro, 3.XII.1957 (Birabén), 1 fêmea (FCNM; identificado como C. concinna Fowler, A.M.M. Remes-Lenicov det.); San Ignacio, XII.1946 (T. Montes), 


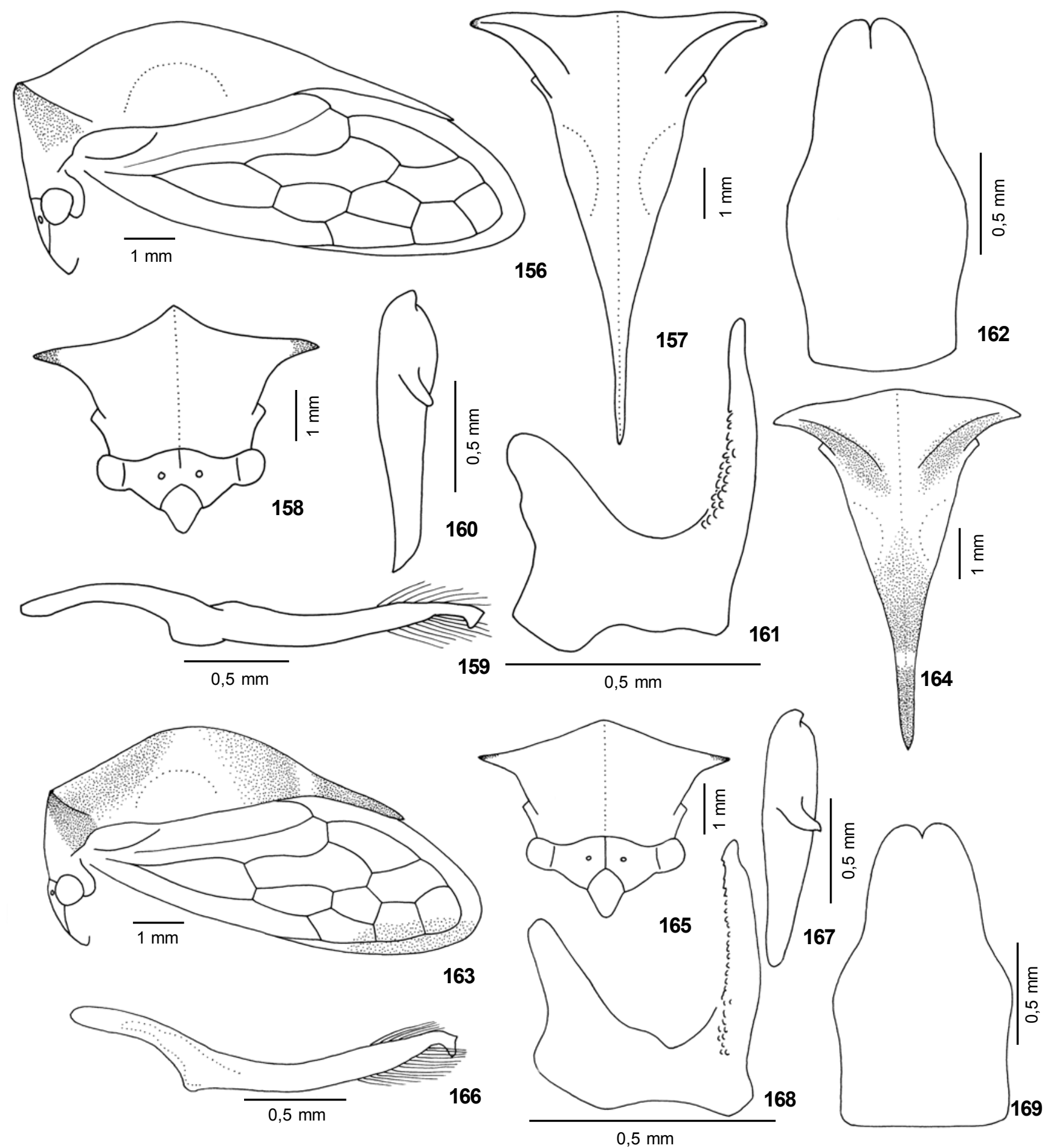

Figuras 156-169. (156-162) Ceresa malina: (156) cabeça, pronoto e tégmina, vista lateral; (157) pronoto, vista dorsal; (158) cabeça e pronoto, vista frontal; (159) parâmero esquerdo, vista lateral; (160) placa lateral esquerda do pigóforo, vista lateral; (161) edeago, vista lateral; (162) placa subgenital, vista ventral; (163-169) Ceresa plaumanni: (163) cabeça, pronoto e tégmina, vista lateral; (164) pronoto, vista dorsal; (165) cabeça e pronoto, vista frontal; (166) parâmero esquerdo, vista lateral; (167) placa lateral esquerda do pigóforo, vista lateral; (168) edeago, vista lateral; (169) placa subgenital, vista ventral. 
1 macho (FCNM; identificado como C. concinna Fowler, A.M.M. Remes-Lenicov det.); Leandro N. Alem, X.1958 (A. Martinez), 1 fêmea (MZUSP). Sem indicação de localidade, sem data (sem coletor), 4 fêmeas (MZUSP; identificado como C. concinna Fowler, A.M.M. Remes-Lenicov det.).

Distribuição geográfica. BRASIL: (?) Pará, São Paulo, Paraná, Santa Catarina e Rio Grande do Sul (SaKakibara 1977) e Minas Gerais. Paraguai: Central (Remes-Lenicov 1973). Argentina: Misiones e Catamarca (Remes-Lenicov 1973).

Localidade-tipo. BRASIL, Santa Catarina: Nova Teutônia.

Notas sobre os tipos. O holótipo fêmea está depositado na DZUP, em bom estado de conservação, alfinetado e com o abdome não dissecado. Faltam antena direita, trocânter, fêmur, tíbia e tarso II direitos e fêmur, tíbia e tarso III direitos. Segundo a descrição original, existem seis parátipos machos e quatorze parátipos fêmeas no MZUSP, quinze parátipos machos e vinte oito parátipos fêmeas também na DZUP e um parátipo macho e um parátipo fêmea na UM. Destes foram localizados e examinados apenas dois parátipos machos e um parátipo fêmea depositados na DZUP.

Planta hospedeira. Desconhecida.

Comentários. Foram observadas variações na coloração geral, na inclinação e na direção dos ápices dos processos supra-umerais, e no grau de extensão do ápice do pronoto com relação a altura da base da $3^{\mathrm{a}}$ célula apical das tégminas.

Difere das demais espécies notadamente pelo padrão de coloração.

\section{Ceresa denticulata Andrade, 2002 Figs 170-176}

Ceresa denticulata Andrade, 2002: 46, figs 5 e 6, 17 a 20.

Medidas. Macho (holótipo)/fêmea (parátipo). Largura da cabeça: 3,24/3,28; comprimento da cabeça: 1,56/1,60; distância entre os ângulos umerais: 3,44/3,64; distância entre os ápices dos processos supra-umerais: 5,42/5,92; comprimento do pronoto: 8,08/8,50; comprimento total: 9,50/9,75.

Descrição. Macho. Coloração geral amarelada, com máculas esbranquiçadas. Ápices dos processos supra-umerais e do pronoto acastanhados. Tégminas e veias hialinas. Região ventral do corpo amarelada, com os esternos abdominais com máculas enegrecidas. Pernas ferruginosas, com as coxas com máculas enegrecidas.

Cabeça calosa junto a margem superior na direção dos ocelos, com a superfície estriada na base e nos espaços ocelooculares, lisa no espaço interocelar e corrugada nas demais regiões. Sutura coronal atingindo a base do frontoclípeo, mais marcada junto a margem superior. Espaço interocelar convexo, espaços ocelo-oculares planos. Lóbulos supra-antenais planos, com as margens sinuosas. Frontoclípeo sublosângico, metade distal com os bordos laterais inteiros e dirigida para trás.

Pronoto com pontuação homogênea, não abaulado nas regiões adjacentes às impressões semicirculares, fortemente ele- vado atrás do espaço entre os processos supra-umerais, abruptamente em declive e afilado para o ápice após o ponto mais elevado e não constricto ao nível do ângulo interno das tégminas. Metopídio trapezoidal, com as impressões musculares irregulares e fortemente impressas. Lóbulos pós-oculares com a superfície corrugada, sulcados ao nível do ângulo externo dos olhos e intumescidos na porção distal. Sulcos supra-umerais bem marcados, regiões supra-umerais com a superfície pontuada. Processos supra-umerais desenvolvidos, prismáticos na metade basal e cônicos na metade distal, retos na metade distal, dirigidos para os lados, sem inclinação e com os ápices voltados para os lados; face dorsal arredondada, face posterior pontuada; espaço entre eles plano; arestas A e P ausentes na metade distal; aresta $\mathrm{M}$ pronunciada como um intumescimento somente na metade basal; espaço anterior a aresta $\mathrm{M}$ normal, espaço posterior a aresta $\mathrm{M}$ escavado. Impressões semicirculares pouco distintas, áreas semicirculares planas e não impressas. Carena dorsal cortante a partir do ponto mais elevado do pronoto. Ápice atingindo a altura da base da $3^{\mathrm{a}}$ célula apical das tégminas.

Tégminas com a veia $\mathrm{R} 1$ originando-se na $2^{\mathrm{a}}$ célula discoidal.

Genitália. Edeago convexo-plano, achatado ântero-posteriormente na porção apical; face dorsal com dentículos bem proeminentes distribuídos em mosaico nos dois quartos medianos. Parâmeros contorcidos na região mediana, achatados lateralmente na metade distal, curvados para cima no quarto distal e com um dentículo conspícuo na porção apical do bordo superior; ápice laminar, mais esclerotinizado, com uma margem cortante no bordo superior e um ponta dirigida para cima; pilosidade longa e divaricada distribuída junto ao dentículo préapical e na face interna da porção apical. Placas laterais do pigóforo com o dente apical intumescido, situado no ângulo central; dente lateral rudimentar, localizado no terço superior, discretamente curvado para cima e com o ápice arredondado. Placa subgenital piriforme, quase duas vezes mais longa que larga no terço basal, estreitando-se após a região mediana.

Fêmea. Semelhante ao macho, apenas um pouco maior.

Material examinado. Peru, Junín: Valle Chanchamayo, 1600 m, IV.1943 (Weyrauch), 1 macho (FML; holótipo, identificado como C. affinis Fairmaire, A.M.M. Remes-Lenicov det. e C. vitulus (Fabricius), J.A. Ramos det.); Valle Chanchamayo, 1400 m, 13.VIII.1951 (Weyrauch), 1 fêmea (FML; identificado como C. affinis Fairmaire, A.M.M. Remes-Lenicov det. e $C$. vitulus (Fabricius), J.A. Ramos det.); Huánuco: Tingo Maria, 2050 m, 15.V.1972 (Bordón), 1 fêmea (CB); Cuzco: Tambo Eneñas, 5.VII.1920 (Cornell Univ. Exp.), 3 machos (CU; um exemplar identificado como C. sallei Stål, W.D. Funkhouser det.). (Todos os exemplares examinados pertencem à série-tipo).

Distribuição geográfica. Peru: Junín (Remes-Lenicov 1973), Huánuco e (?) Cuzco (ANDRAde 2002).

Localidade-tipo. Peru, Junín: Valle Chanchamayo.

Notas sobre os tipos. O holótipo macho está depositado na FML, em razoável estado de conservação, alfinetado e com 
o abdome dissecado. O ápice do pronoto está quebrado, faltam o tarso II esquerdo e o trocânter, fêmur, tíbia e tarso II e III direitos. Existem um parátipo fêmea na coleção $\mathrm{CB}$, três parátipos machos na CU e um parátipo fêmea também na FML.

Planta hospedeira. Desconhecida.

Comentários. Difere das demais espécies notadamente pela escultura da superfície da cabeça e pela conformação do pronoto.

\section{Ceresa vitulus (Fabricius, 1775) Figs 177-183}

Membracis Vitulus (sic) Fabricius, 1775: 677; Zimsen, 1964: 286 (rep. tip.).

Membracis vitulus; Broomfield, 1971: 385 (tip.).

Ceresa vitulus; Metcalf \& Wade, 1965: 868 (cat.); Remes-Lenicov, 1973: 85, lám. XI, figs 76 a 84 (rdescr., gen. masc. fem.), 79, 87, 88 e 131 (not.); Kopp \& Yonke, 1979: 24, figs 242 a 249 (list.), 25 (tip.); McKamey, 1998: 246 (cat.).

Membracis pallens Germar, 1821: 25; Metcalf \& Wade, 1965:

865 (cat., = C. vitulus (Fabricius, 1775)); McKamey, 1998:

246 (cat., = C. vitulus (Fabricius, 1775))

Ceresa excisa Walker, 1858a: 68. syn. rev.

Ceresa excisa; Metcalf \& Wade, 1965: 862 (cat.); Broomfield, 1971: 348 (tip.); Kopp \& Yonke, 1979: 24 (list.); McKamey, 1998: 245 (cat.).

Ceresa curvilinea Walker, 1858b: 132. part.

Ceresa curvilinea; Metcalf \& Wade, 1965: 862 (cat., = C. vitulus (Fabricius, 1775)); Broomfield, 1971: 344 (tip.); McKamey, 1998: 246 (cat., $=$ C. vitulus (Fabricius, 1775)).

Medidas. Macho (lectótipo)/fêmea. Largura da cabeça: 2,60/2,80; comprimento da cabeça: 1,30/1,40; distância entre os ângulos umerais: 2,60/2,80; distância entre os ápices dos processos supra-umerais: $4,52 / 4,48$; comprimento do pronoto: 6,50/6,58; comprimento total: 8,08/7,75.

Descrição. Macho. Coloração geral amarelo-pálida. Duas faixas que partem da face posterior dos processos supra-umerais e circundam as áreas semicirculares esbranquiçadas; ápices dos processos supra-umerais e do pronoto negros. Tégminas hialinas, veias amareladas. Região ventral do corpo e pernas amareladas.

Cabeça com a superfície fracamente estriada na base e nos espaços ocelo-oculares, lisa nas demais regiões. Sutura coronal não atingindo a base do frontoclípeo. Espaço interocelar convexo, espaços ocelo-oculares planos. Lóbulos supra-antenais escavados, com as margens sinuosas. Frontoclípeo piriforme, metade distal com os bordos laterais inteiros e dirigida para baixo.

Pronoto com pontuação homogênea, não abaulado nas regiões adjacentes às impressões semicirculares, regularmente elevado atrás do espaço entre os processos supra-umerais, gradualmente em declive e afilado para o ápice após o ponto mais elevado e não constricto ao nível do ângulo interno das tégmi- nas. Metopídio trapezoidal, com as impressões musculares em forma de L invertido. Lóbulos pós-oculares com a superfície corrugada, sem modificações ao nível do ângulo externo dos olhos. Sulcos supra-umerais bem marcados, regiões supraumerais com a superfície pontuada. Processos supra-umerais desenvolvidos, prismáticos na metade basal e cônicos na metade distal, curvos na metade distal, dirigidos para os lados, inclinados para baixo e com os ápices voltados para os lados e para trás; face dorsal arredondada, face posterior pontuada na metade basal e lisa na metade distal; espaço entre eles convexo; arestas A e P ausentes na metade distal; aresta $\mathrm{M}$ pronunciada como um intumescimento somente na metade basal; espaço anterior a aresta $\mathrm{M}$ normal, espaço posterior a aresta $\mathrm{M}$ escavado. Impressões semicirculares pouco distintas, áreas semicirculares planas e bem impressas. Carena dorsal cortante a partir do ponto mais elevado do pronoto. Ápice não atingindo a altura da base da $3^{\text {a }}$ célula apical das tégminas.

Tégminas com a veia $\mathrm{R} 1$ originando-se na $2^{\mathrm{a}}$ célula discoidal.

Genitália. Edeago achatado ântero-posteriormente, espatulado na porção apical e com o ápice um pouco curvado para trás; face dorsal com uma fileira de dentículos de cada lado nos dois quartos medianos, um pouco divergentes entre si. Parâmeros achatados dorso-ventralmente na metade distal, um pouco curvados para dentro e dilatados no quarto distal, e abruptamente estreitados na porção apical; ápice espatulado, mais esclerotinizado, com uma margem cortante no bordo inferior; pilosidade longa e heterogênea, esparsamente distribuída ao nível do quarto distal. Placas laterais do pigóforo com o dente apical intumescido, situado no ângulo central; dente lateral bem desenvolvido, localizado no terço mediano, curvado para baixo e para trás e com o ápice agudo. Placa subgenital quase duas vezes mais longa que larga na metade basal, constricta na região mediana e estreitada distalmente.

Fêmea. Semelhante ao macho, apenas um pouco maior.

Material examinado. ColômBIA, Cundinamarca: Guayabetal, 18.IX.1965 (J.A. Ramos), 1 fêmea (UPR); Sem indicação de Departamento: sem indicação de localidade, 11.III.1912 (sem coletor), 1 macho (CU). Venezuela, Bolivar: rio Caura, Suapure, 5.II.1899 (E.A. Klages), 1 macho (CU); rio Caura, Suapure, 29.IV.1899 (E.A. Klages), 1 fêmea (CU). SuRINAmE, Saramacca: rio Saramacca, Kwakoegron, 10.VI.1927 (sem coletor), 1 macho (CU). Brasil, Pará: Belém, IX.1964 (E. Dente), 1 fêmea (MZUSP); serra dos Carajás, X.1986 (O. Roppa), 2 machos e 16 fêmeas (CACS); Jacareacanga, XII.1968 (M. Alvarenga), 1 macho e 16 fêmeas (DZUP); Amazonas: BR 174, km 45, 2.IV.1982 (A.T.S. Jatahy), 1 fêmea (INPA); BR 174, km 45, 2.IV.1982 (E.F. Ribeiro), 1 fêmea (INPA); BR 174, km 45, 4.IV.1982 (E.L. Oliveira), 1 macho (INPA); Manaus, sem data (Huebner), 1 macho e 3 fêmeas (MZUSP); Manaus, reserva Ducke, V.1968 (E.V. Silva \& A. Faustino), 1 fêmea (INPA); Manaus, reserva Ducke, 29.VII.1971 (J. Becker), 1 macho (MN); Manaus, reserva Ducke, 1.X.1976 (N.D. Penny), 1 macho (INPA); Manaus, E.E. Silvic. 
Tropical, 31.VII.1981 (F.A.P.L. Costa), 1 fêmea (BCL); Manaus, Cidade Universitária, 17.V.1982 (J.A. Rafael), 1 macho (INPA); Manaus, F.U.A., 25.V.1982 (L.R. La Torre), 1 macho e 1 fêmea (INPA); Manaus, INPA, 26.IV.1976 (E. Castellón B.), 1 macho (INPA); Manaus, INPA, V.1982 (V. Py-Daniel), 1 fêmea (INPA); Manaus, INPA, 13.V.1982 (J.A. Rafael), 1 fêmea (INPA); Manaus, INPA, 17.V.1982 (J.A. Rafael), 1 macho (INPA); Manaus, INPA, 3.IV.1986 (A. Henriques \& R. Sampaio), 1 fêmea (INPA); Manaus, INPA, 4.IV.1986 (M.G. Paes), 1 macho e 1 fêmea (INPA); rio Purus, lago de Beruri, 6-8.IV.1967 (Exp. Perm. Amaz.), 1 fêmea (MZUSP); Tabatinga, VII.1958 (E. Lima), 2 fêmeas (CACS); Tabatinga, IX.1958 (E. Lima), 1 fêmea (CACS); Benjamim Constant, I.1961 (L.G. Pereira), 2 machos e 7 fêmeas (CACS); Benjamin Constant, 18-28.IX.1962 (K. Lenko), 1 fêmea (MZUSP); Humaitá, VIII.1980 (G.S. Andrade), 2 machos e 3 fêmeas (CACS); Pernambuco: Caruaru, 900 m, V.1972 (J.M. Lima), 1 fêmea (DZUP); Acre: Cruzeiro do Sul, 330 m, II.1963 (M. Alvarenga), 3 machos e 5 fêmeas (MZUSP); Rondônia: Porto Velho, 16.III.1979 (D. Need), 1 macho (INPA); Ouro Preto d'Oeste, 4.X.1986 (J. Becker), 1 fêmea (MN); Bahia: Itapetinga, 23-27.VII.1967 (C. \& C.T. Elias), 2 fêmeas (DZUP; um exemplar comparado com o lectótipo de Membracis vitulus Fabricius); Minas Gerais: Juiz de Fora, 13.IV.1975 (G.S. Andrade), 1 macho e 2 fêmeas (DZUP); Pouso Alegre, 2425.VI.1965 (Vulcano \& Pereira), 4 machos e 10 fêmeas (MZUSP); Espírito Santo: Santa Teresa, 28.III.1967 (C.T. \& C. Elias), 1 fêmea (DZUP); Santa Teresa, 23-31.V.1967 (C. \& C.T. Elias), 2 machos e 2 fêmeas (DZUP); Santa Teresa, 26.VI.1967 (C.T. \& C. Elias), 1 macho e 1 fêmea (DZUP); Santa Teresa, 1-8.IX.1967 (C. \& C.T. Elias), 2 machos e 1 fêmea (DZUP; um exemplar macho comparado com o lectótipo de Membracis vitulus Fabricius); Santa Teresa, 12.IX.1967 (C.T. \& C. Elias), 1 macho (DZUP); Santa Teresa, 27.IX.1967 (C.T. \& C. Elias), 2 machos e 1 fêmea (DZUP); Cariacica, 2-8.V.1967 (C. Elias \& C.T. Elias), 2 fêmeas (DZUP); São Paulo: Leme, sem data (M.C. Leite), 1 fêmea (MZUSP); Barueri, 5.VI.1966 (K. Lenko), 1 fêmea (MZUSP); Barueri, 12.VI.1966 (K. Lenko), 3 machos e 1 fêmea (MZUSP); São Paulo, 25.I.1933 (M.C. Leite), 1 fêmea (IB); São Paulo, X.1935 (M.C. Leite), 1 macho (MZUSP); São Paulo, Ipiranga, sem data (sem coletor), 1 fêmea (MZUSP); Osasco, XII.1960 (M.A. Vulcano),1 macho (MZUSP); [Caraguatatuba], Porto Novo, 20.XI.1942 (J.P. Fonseca), 1 fêmea (IB); Caraguatatuba, res. flor., 40 m, VII.1965 (Exp. Dep. Zool.), 1 macho (MZUSP); Rio de Janeiro: Vassouras, I.1940 (D. Machado), 1 macho (FIOC); Teresópolis, XI.1940 (Freitas), 1 fêmea (FIOC); Itatiaia, 5.II.1957 (M.A. Vulcano), 1 fêmea (MZUSP); Magé, 400 m, 17.I.1985 (V.O. Becker), 1 macho (DZUP); Duque de Caxias, São Bento, VIII.1960 (F.M. Oliveira), 3 machos e 2 fêmeas (CACS); Duque de Caxias, Imbariê, VIII.1961 (M. Alvarenga), 2 machos e 1 fêmea (DZUP); Rio de Janeiro, Jacarepaguá, Taquara, 7.I.1940 (Oliveira), 2 fêmeas (FIOC); Rio de Janeiro, Jacarepaguá, 25.IX.1981 (C.A.C. Seabra), 1 macho (CACS); Rio de Janeiro, Cordovil, X.1941 (Antonio), 1 fêmea (FIOC); Rio de Janeiro, Guaratiba, XII.1955 (J.H. Guimarães), 1 fêmea (FIOC); Rio de Janeiro, Guaratiba, II.1956 (J.H. Guimarães), 1 macho e 1 fêmea
(FIOC); Rio de Janeiro, represa Rio Grande, 15.II.1967 (F.M. Oliveira), 2 fêmeas (DZUP); Muriqui, X.1961 (M. Alvarenga), 4 fêmeas (DZUP); Muriqui, VII.1969 (M. Alvarenga), 6 machos, 8 fêmeas e 1 sem abdome (DZUP); sem indicação de localidade, 20.X.1919 (Cornell Univ. Exp.), 2 fêmeas (CU); sem indicação de localidade, XII.1929 (C. Lacerda), 1 fêmea (MZUSP); sem indicação de localidade, sem data (De Vylder), 1 macho (MZUSP). Equador, Napo: Coca, V.1965 (L.E. Peña), 2 fêmeas (UPR); Pastaza: El Puyo, 950 m, 10.IV.1958 (Weyrauch), 1 fêmea (FML; identificado como C. vacca Fowler, H.L. Rihtv...det. e como C. vitulus (Fabricius), A.M.M. Remes-Lenicov det.). Peru, Loreto: W de Iquitos, 4.II. 1984 (L. Huggert), 1 fêmea (LU); Ucayali: Pucallpa, Neshuya, 16.XII.1970 (R. Garcia), 2 fêmeas (MHNJP); Huánuco: Tingo Maria, IV.1963 (L.E. Peña), 1 macho e 4 fêmeas (UPR); Tingo Maria, 26.I.1984 (L. Huggert), 2 fêmeas (LU); Pasco: Iscozacín, 250 m, 12.VIII.1987 (P. Lozada), 1 macho (MHNJP); San Juan de Cacazú, 830 m, 15.VIII.1987 (P. Lozada), 1 macho (MHNJP); Madre de Dios: Tambopata, "malaise trap", 21.II.1987 (P. Lozada), 1 fêmea (MHNJP); Tambopata, "malaise trap", 2425.III.1987 (P. Lozada), 1 fêmea (MHNJP); Junín: Satipo, 21.I.1984 (L. Huggert), 1 fêmea (LU). Argentina, Salta: Orán, II.1967 (Golbach), 1 macho (FML); Misiones: San Favies, 4.VII.1937 (Denier), 1 fêmea (FCNM). "America", sem indicação de localidade, sem data (sem coletor), 1 macho (ZM; lectótipo).

Distribuição geográfica. Colômbia: Cundinamarca. VENEzuela: Bolivar. Suriname: Saramacca. Brasil: Rio de Janeiro (RemesLenicov 1973), Pará, Amazonas, Pernambuco, Acre, Rondônia, Bahia, Minas Gerais, Espírito Santo e São Paulo. Equador: Pastaza (Remes-Lenicov 1973) e Napo. Peru: Huánuco e Junín (RemesLenicov 1973), Loreto, Ucayali, Pasco e Madre de Dios. Argentina: Salta, Catamarca e La Rioja (Remes-Lenicov 1973) e Misiones.

Localidade-tipo. "Habitat in America. Drury." (Fabricius 1775). Segundo J.S. Moure (comunicação pessoal), D. Drury, assim como outros naturalistas holandeses, obtiveram material na América do Sul principalmente nas "Guianas". A existência de três exemplares de Stictolobus minor (Fowler, 1895) entre os síntipos de Membracis vitulus Fabricius (cf. Kopp \& Yonke 1979), vem reforçar a opinião de que a localidade-tipo de $C$. vitulus seja ao menos próxima à alguma das três "Guianas". $S$. minor tem o limite meridional de dispersão até então conhecido situado na altura do paralelo $0^{\circ}$ de latitude e, como de fato, C. vitulus é simpátrica com $S$. minor ao menos em parte do norte da América do Sul, acima do paralelo referido, onde é comprovado o seu limite setentrional de distribuição.

A localidade-tipo de Membracis pallens Germar foi indicada como um vaguíssimo "...Habitat in Brasilia." (Germar 1835), ao passo que a de C. curvilinea Walker pode ser precisada com maior acuracidade. Segundo Broomfield (1971), existe uma etiqueta “...'Brazil; $51 ; 55^{\prime} . .$. " apensa ao alfinete do lectótipo fêmea desta espécie, embora a descrição original indique claramente " $a$. Rio Negro. From Mr. Wallace's collection." e "b. Venezuela. From Mr. Birschell's collection.", respectivamente, para os dois exemplares examinados. É possível que os 


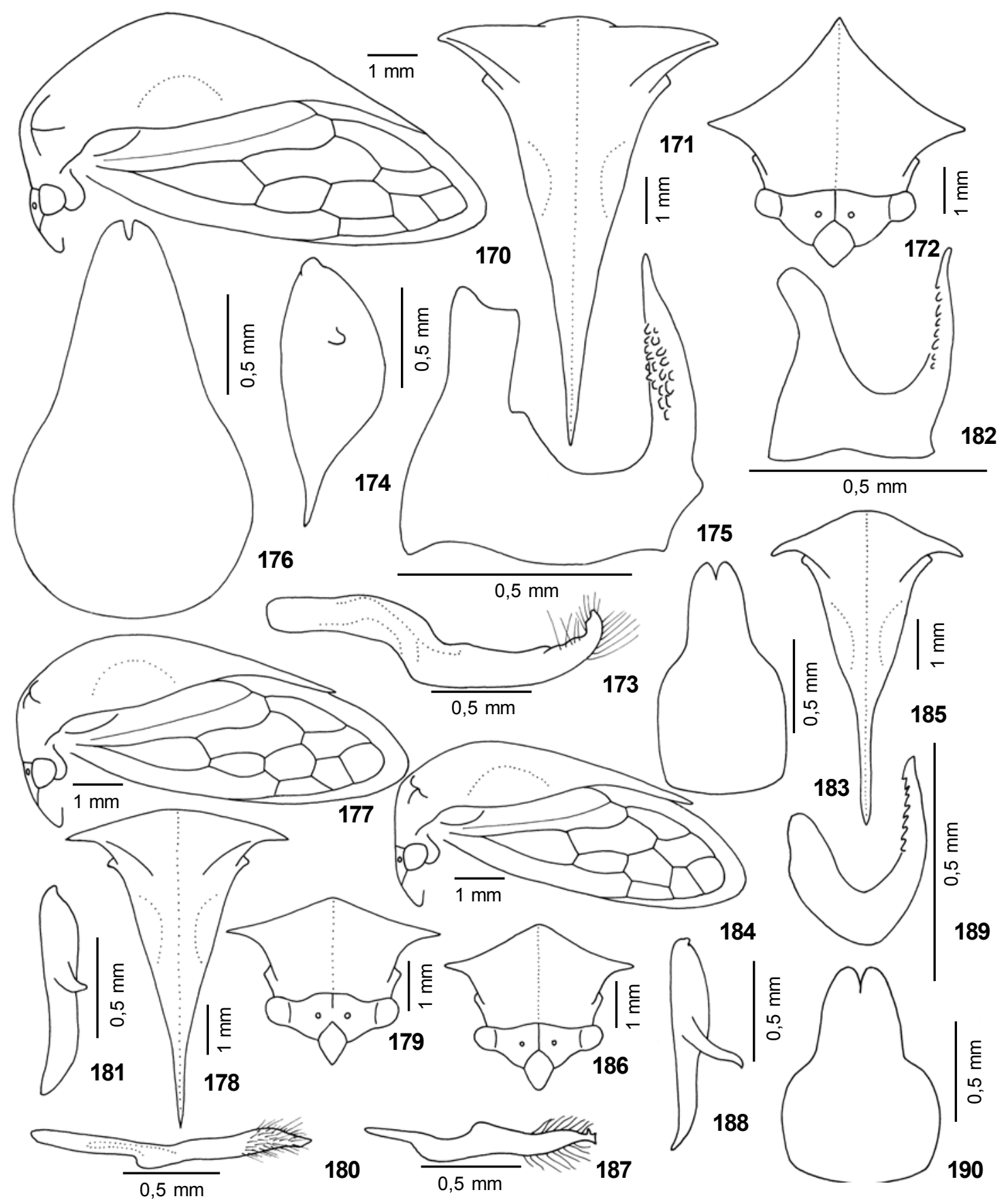

Figuras 170-190. (170-172) Ceresa denticulata: (170) cabeça, pronoto e tégmina, vista lateral; (171) pronoto, vista dorsal; (172) cabeça e pronoto, vista frontal; (173-176) Ceresa denticulata: (173) parâmero esquerdo, vista lateral; (174) placa lateral esquerda do pigóforo, vista lateral; (175) edeago, vista lateral; (176) placa subgenital, vista ventral; (177-183) Ceresa vitulus: (177) cabeça, pronoto e tégmina, vista lateral; (178) pronoto, vista dorsal; (179) cabeça e pronoto, vista frontal; (180) parâmero esquerdo, vista lateral; (181) placa lateral esquerda do pigóforo, vista lateral; (182) edeago, vista lateral; (183) placa subgenital, vista ventral; (184-190) Ceresa albosignata: (184) cabeça, pronoto e tégmina, vista lateral; (185) pronoto, vista dorsal; (186) cabeça e pronoto, vista frontal; (187) parâmero esquerdo, vista lateral; (188) placa lateral esquerda do pigóforo, vista lateral; (189) edeago, vista lateral; (190) placa subgenital, vista ventral.

Revista Brasileira de Zoologia 21 (4): 671-738, dezembro 2004 
números constantes na etiqueta sejam referentes a algum registro existente no BMNH e possam precisar mais a localidadetipo desta espécie. Mas em ambas as espécies, as indicações originais e subsequentes são compatíveis com a área de distribuição admitida para C. vitulus.

Notas sobre os tipos. Foram feitas duas designações de lectótipo para Membracis vitulus Fabricius, uma por Broomfield (1971), sobre um exemplar pertencente à coleção J. Banks, depositada no BMNH, e outra por Kopp \& Yonke (1979), dentre os síntipos desta espécie existentes na coleção J.C. Fabricius, depositada no ZM. Embora, à primeira vista, a designação de BRoOMFIELD (1971) tenha prioridade, optou-se por considerar o exemplar designado por Kopp \& YonKe (1979) como o verdadeiro lectótipo desta espécie.

No primeiro caso não há como comprovar com certeza a autenticidade do exemplar como síntipo e, além do mais, como o exemplar é fêmea, fica difícil a caracterização do gênero Ceresa com base na genitália masculina. Já no segundo caso as evidências a favor da autenticidade dos síntipos são mais consistentes. STÅL (1869a) cita “...(Mus. Havn. et FABRICII.)" como repositório de síntipos de C. vitulus e Zimzen (1964) faz referência a cinco síntipos existentes na coleção depositada originalmente em Kiel, mas a nenhum pertencente a coleção J. Banks. O lectótipo designado por Kopp \& YONKE (1979) corresponde à interpretação dos autores para a espécie e à recaracterização do gênero feita por CaLDWell (1949), o que é oportuno do ponto de vista da estabilidade da nomenclatura.

Cabe ressaltar que a análise do catálogo de BRoOMFIELD (1971) indica desconhecimento ou omissão da contribuição de Zimzen (1964) e que o exame do lectótipo depositado no BMNH mostrou que ele não é conspecífico com o lectótipo depositado no ZM.

O lectótipo está em mal estado de conservação, alfinetado e com o abdome dissecado, e superficialmente fungado e empoeirado. Falta a antena esquerda, o dorso do pronoto está quebrado ao nível da parte posterior das regiões adjacentes às impressões semicirculares e as tégminas estão abertas.

Planta hospedeira. Desconhecida.

Comentários. FaIRMAIRE (1846) colocou Membracis pallens Germar na sinonímia de C. vitulus, mas a identidade entre as duas espécies só poderá ser confirmada após a definição do tipo da espécie descrita por E.F. Germar.

C. curvilinea Walker foi incluída na sinonímia de $C$. vitulus por Butler (1877). O estudo da descrição de WALKer (1858b) e o exame do lectótipo fêmea desta espécie mostrou que esta opinião é correta. Adicionalmente, respondendo a envio prévio de material identificado como C. vitulus ao BMNH, para comparação com os tipos de C. curvilinea e de C. excisa Walker, P.S. Broomfield (comunicação pessoal) informou: "Iam satisfied that the synonymy of Ceresa curvilinea Walker with C. vitulus (Fabricius) is correct but am less sure about C. excisa Walker. The unique type of this species is considerably smaller than any of the many specimens of vitulus in the collection and the pronotum is slightly less elevated; unfortunately, though from its small size I assume the specimem to be a male, the abdomen is missing and I am unable to make any comparison of genitalia. Such a synonymy as proposed therefore seems to me extremely doubtful." (sic).

A sinonímia de C. excisa Walker com C. vitulus (Fabricius) foi feita por ButLer (1877), o que foi seguido pela maioria dos autores subsequentes. Apesar das considerações de P.S. Broomfield, o exame do lectótipo mostrou que a espécie se enquadra dentre a variabilidade de $C$. vitulus, o que permite revalidar a sinonímia proposta por BUTLER (1877).

O estudo do paralectótipo macho de C. curvilinea Walker mostrou que o mesmo corresponde a C. albosignata RemesLenicov.

Foram observadas variações na coloração, principalmente nas tégminas, e na extensão e na inclinação dos processos supra-umerais.

Difere das demais espécies notadamente pela tonalidade pálida da coloração e pela conformação do pronoto e dos processos supra-umerais.

\section{Ceresa albosignata Remes-Lenicov, 1973 Figs $184-190$}

Ceresa albosignata Remes-Lenicov, 1973: 77, lám. VIII, figs 49 a 57; McKamey, 1998: 244 (cat.).

Ceresa curvilinea Walker, 1858b: 132. part.

Medidas. Macho (holótipo)/fêmea (alótipo). Largura da cabeça: 2,48/2,68; comprimento da cabeça: 1,24/1,34; distância entre os ângulos umerais: $2,52 / 2,76$; distância entre os ápices dos processos supra-umerais: $3,88 / 4,24$; comprimento do pronoto: 6,33/6,33; comprimento total: 7,42/7,58.

Descrição. Macho. Coloração geral amarelo-ferruginosa. Cabeça, metopídio, espaço entre os processos supra-umerais, regiões supra-umerais, áreas semicirculares e região posterior do pronoto com máculas esbranquiçadas; margens laterais do pronoto adiante dos ângulos umerais e duas faixas que partem da face posterior dos processos supra-umerais e circundam as áreas semicirculares, esbranquiçadas; ápices dos processos supra-umerais e do pronoto negros. Tégminas hialinas, veias acastanhadas, mais escurecidas no terço distal. Região ventral do corpo e pernas ferruginosas.

Cabeça com a superfície fracamente estriada, corrugada no frontoclípeo e nos lóbulos supra-antenais. Sutura coronal atingindo a base do frontoclípeo. Espaço interocelar convexo, espaços ocelo-oculares deprimidos. Lóbulos supra-antenais escavados, com as margens sinuosas. Frontoclípeo piriforme, metade distal com os bordos laterais inteiros e dirigida para baixo.

Pronoto com pontuação homogênea, não abaulado nas regiões adjacentes às impressões semicirculares, regularmente elevado atrás do espaço entre os processos supra-umerais, gradualmente em declive e afilado para o ápice após o ponto mais 
elevado e não constricto ao nível do ângulo interno das tégminas. Metopídio trapezoidal, com as impressões musculares em forma de L invertido. Lóbulos pós-oculares com a superfície corrugada, sulcados ao nível do ângulo externo dos olhos. Sulcos supra-umerais bem marcados, regiões supra-umerais com a superfície lisa. Processos supra-umerais desenvolvidos, prismáticos na metade basal e cônicos na metade distal, curvos na metade distal, dirigidos para os lados, inclinados para baixo e com os ápices voltados para os lados e para trás; face dorsal arredondada, face posterior pontuada na metade basal e lisa na metade distal; espaço entre eles convexo; arestas A e P ausentes na metade distal; aresta $\mathrm{M}$ pronunciada como um intumescimento somente na metade basal; espaços anterior e posterior a aresta $\mathrm{M}$ normais. Impressões semicirculares pouco distintas, áreas semicirculares planas e não impressas. Carena dorsal cortante a partir do ponto mais elevado do pronoto. Ápice não atingindo a altura da base da $3^{\mathrm{a}}$ célula apical das tégminas.

Tégminas com a veia $\mathrm{R} 1$ originando-se na $2^{\mathrm{a}}$ célula discoidal.

Genitália. Edeago achatado ântero-posteriormente; face dorsal com uma fileira de dentículos de cada lado nos dois terços distais, paralelas entre si. Parâmeros achatados lateralmente na metade distal, curvados para fora e depois para dentro no terço distal e abruptamente estrangulados na porção apical; ápice bidenteado, mais esclerotinizado, com as duas pontas dirigidas para cima; pilosidade longa e homogênea distribuída na face interna, ao nível do terço distal. Placas laterais do pigóforo com o dente apical proeminente, situado no ângulo central; dente lateral desproporcionalmente bem desenvolvido, localizado no terço mediano, diagonalmente dirigido para baixo, com o ápice afilado e curvado também para baixo. Placa subgenital quase uma vez e meia mais longa que larga na metade basal, constricta na região mediana e estreitada distalmente.

Fêmea. Semelhante ao macho, apenas um pouco maior. Material examinado. ColômBia, Cundinamarca: Bogotá, sem data (Lindig), 2 fêmeas (MZUSP; um exemplar identificado como C. vitulus (Fabricius), A.M.M. Remes-Lenicov det.); Monterredondo, 1400 m, I.1959 (sem coletor), 1 fêmea (MZUSP); Meta: entre Villavicencio e Granada, em Mimosa invisa, 25.VI.1986 (C. Garcia), 4 machos e 1 fêmea (DZUP). Venezuela, Distrito Federal: El Limón, 1300 m, 19.III.1967 (Bordón), 1 macho (CB); Carabobo: Puerto Cabello, sem data (sem coletor), 1 fêmea (MZUSP); Miranda: Alpes del Tuy, Parque Nacional Guatopo, 400 m, 20.XI.1966 (C. Bordón), 1 fêmea (CB); Lara: Sanare, Parque Nacional Yacambú, 1500 m, 2.VII.1983 (Bordón), 1 macho (CB); Aragua: Cagua, 22.V.1951 (Ronderos), 1 macho (FCNM; holótipo); Trujillo: Trujillo, 19.II.1952 (Ronderos), 1 fêmea (FCNM; alótipo); Mosquey, Boconó, 1500 m, 22-27.VII.1967 (Bordón), 1 fêmea (CB); Delta Amacuro: Isla C. Mánamo, 20 K S Tucupita, 3-8.I.1967 (Bordón), 1 macho (CB); Bolivar: rio Caura, Suapure, 28.VI.1899 (E.A. Klages), 1 fêmea (CU; identificado como C. vitulus (Fabricius),
D.D. Kopp det.); rio Caura, Suapure, 18.X.1899 (E.A. Klages), 2 machos e 1 fêmea (CU; identificado como C. vitulus (Fabricius), D.D. Kopp det.). BrasiL, Amazonas: Tapuruquara, VII.1962 (F.M. Oliveira), 1 fêmea (DZUP); Tapuruquara, VIII.1962 (F.M. Oliveira), 1 macho (DZUP); rio Negro, Tapuruquara, 26-27.XI.1962 (J. Bechyné), 2 fêmeas (MZUSP). Equador, Napo: Sacha, 5.III.1983 (L. Huggert), 1 macho e 1 fêmea (LU); Coca, V.1965 (L.E. Peña), 2 machos (UPR).

Distribuição geográfica. ColômbIA: Cundinamarca e Meta. Venezuela: Aragua e Trujillo (Remes-Lenicov 1973), Distrito Federal, Carabobo, Miranda, Lara, Delta Amacuro e Bolivar. BRASIL: Amazonas. EQUADOR: Napo.

Localidade-tipo. Venezuela, Aragua: Cagua.

Notas sobre os tipos. O holótipo macho está depositado na FCNM, em bom estado de conservação, alfinetado e com o abdome dissecado. Falta o flagelo antenal direito, o ápice do processo supra-umeral direito está ralado e o tarso II direito está quebrado. Existe o alótipo fêmea depositado também na FCNM (examinado).

Planta hospedeira. Mimosa invisa (observação de C. Garcia).

Comentários. O estudo do paralectótipo macho de $C$. curvilinea Walker mostrou que o mesmo corresponde a $C$. albosignata Remes-Lenicov.

Foram observadas variações na coloração, principalmente nas tégminas, e na inclinação dos processos supra-umerais.

Esta espécie é muito semelhante a C. vitulus (Fabricius). Difere notadamente pelo padrão de coloração e por apresentar a cabeça com a superfície mais fortemente esculturada.

\section{Ceresa spinifera Fairmaire, 1846 sp. rev. Figs 191-193}

Ceresa spinifera Fairmaire, 1846: 284. sp. rev.

Ceresa spinifera; Metcalf \& Wade, 1965: 867 (cat., = C. vitulus

(Fabricius, 1775)); McKamey, 1998: 246 (cat., = C. vitulus (Fabricius, 1775)).

Medidas. Fêmea (lectótipo). Largura da cabeça: 2,44; comprimento da cabeça: 1,32; distância entre os ângulos umerais: 2,52; distância entre os ápices dos processos supra-umerais: 4,32; comprimento do pronoto:...; comprimento total: 7,00.

Descrição. Fêmea. Coloração geral amarelo-pálida. Metade distal dos processos supra-umerais, carena dorsal a partir do ponto mais elevado do pronoto e região posterior do pronoto, acastanhadas; duas faixas que partem da face posterior dos processos supra-umerais e circundam as áreas semicirculares, esbranquiçadas; ápices dos processos supra-umerais e do pronoto negros. Tégminas e veias hialinas. Região ventral do corpo e pernas amareladas.

Cabeça com a superfície fracamente estriada na base e nos espaços ocelo-oculares, lisa nas demais regiões. Sutura coronal não atingindo a base do frontoclípeo. Espaço interocelar convexo, espaços ocelo-oculares deprimidos. Lóbulos su- 
pra-antenais escavados, com as margens arredondadas. Frontoclípeo piriforme, metade distal com os bordos laterais inteiros e dirigida para baixo.

Pronoto com pontuação heterogênea, não abaulado nas regiões adjacentes às impressões semicirculares, regularmente elevado atrás do espaço entre os processos supra-umerais, gradualmente em declive e afilado para o ápice após o ponto mais elevado e não constricto ao nível do ângulo interno das tégminas. Metopídio trapezoidal, com as impressões musculares em forma de L invertido. Lóbulos pós-oculares com a superfície corrugada, sem modificações ao nível do ângulo externo dos olhos. Sulcos supra-umerais bem marcados, regiões supra-umerais com a superfície pontuada. Processos supra-umerais desenvolvidos, prismáticos na metade basal e cônicos na metade distal, retos na metade distal, dirigidos para frente e para os lados, inclinados para cima e com os ápices voltados para os lados; face dorsal arredondada, face posterior pontuada; espaço entre eles côncavo; arestas A e P ausentes na metade distal; aresta $\mathrm{M}$ pronunciada somente na metade basal; espaço anterior a aresta $\mathrm{M}$ intumescido, espaço posterior a aresta $\mathrm{M}$ normal. Impressões semicirculares bem distintas, áreas semicirculares planas e não impressas. Carena dorsal cortante a partir do ponto mais elevado do pronoto. Ápice ultrapassando a altura da base da $3^{\text {a }}$ célula apical das tégminas.

Tégminas com a veia $\mathrm{R} 1$ originando-se na $2^{\mathrm{a}}$ célula discoidal.

Macho. Desconhecido.

Material examinado. Brasil, Paraná: Ponta Grossa, 6.V. 1975 (D. Link), 1 fêmea (DZUP; comparado com o lectótipo). "Brésil", sem indicação de localidade, sem data (sem coletor), 1 fêmea (MRSN; lectótipo, cf. em Notas sobre o(s) tipo(s)).

Distribuição geográfica. BRASIL: Paraná.

Localidade-tipo. "Brésil..." (Fairmaire 1846). Talvez seja possível precisar mais esta indicação. Segundo CASALE (1981), os dados constantes na etiqueta de caixa pertinente ao lectótipo são "Ceresa spinifera Fairmaire, Brésil e Buquet". Em HoRn \& KaHLE (1935-1937) encontramos a informação de que J.B.L. Buquet foi um comerciante de insetos estabelecido em Paris por volta de 1829. Certamente, todo o material existente na coleção M. Spinola com a indicação "Buquet" foi obtido por seu intermédio. Segundo Casolari \& Casolari Moreno (1980), a correspondência mantida por M. Spinola com seus contemporâneos foi toda organizada e deve estar disponível à consulta. É possível que dentre ela existam cartas de J.B.L. Buquet com dados adicionais sobre o material fornecido a M. Spinola, os quais poderiam definir a localidade-tipo desta e de outras espécies com maior acuracidade.

Notas sobre o(s) tipo(s). Segundo a descrição original esta espécie foi descrita com base em material da coleção M. Spinola, atualmente depositada no MRSN. Dentre os exemplares obtidos para estudo junto a esta instituição encontrou-se um, fêmea, que se ajusta à descrição original, o qual é aqui designado como lectótipo.
O exemplar está em mal estado de conservação, alfinetado e com o abdome não dissecado, e um pouco fungado. Faltam antenas, o pronoto está um pouco solto e com a porção apical quebrada e faltam também o trocânter, fêmur, tíbia e tarso I direitos.

A existência de outros síntipos é incógnita.

Planta hospedeira. Desconhecida.

Comentários. STÅL (1869b) colocou esta espécie na sinonímia de C. vitulus (Fabricius, 1775). O estudo comparativo do lectótipo de C. spinifera com o lectótipo de C. vitulus mostrou que se tratam de espécies distintas.

Embora o macho não seja conhecido, o aspecto nitidamente tectiforme do pronoto e a distribuição geográfica até então conhecida permitem incluir esta espécie no gênero Ceresa.

Difere das demais espécies notadamente pelo padrão de coloração e pela conformação do pronoto.

\section{Ceresa viridilineata Funkhouser, 1943 Figs 194-200}

Ceresa viridilineata Funkhouser, 1943: 472, pl. II, fig. 11; Metcalf \& Wade, 1965: 868 (cat.); Kopp \& Yonke, 1974: 137 (rep. tip.); Kopp \& Yonke, 1979: 24, figs 250 a 257 (list.); McKamey, 1998: 246 (cat.).

Medidas. Macho/fêmea (? holótipo). Largura da cabeça: 2,60/2,60; comprimento da cabeça: 1,30/1,30; distância entre os ângulos umerais: 2,60/2,60; distância entre os ápices dos processos supra-umerais:.../4,36; comprimento do pronoto:.../ 6,75; comprimento total: 7,75/7,92.

Descrição. Macho. Coloração geral amarelo-escura. Máculas no metopídio e no espaço entre os processos supraumerais, e duas faixas que partem da face posterior dos processos supra-umerais e circundam as áreas semicirculares, esbranquiçadas; ápices dos processos supra-umerais e do pronoto negros. Tégminas e veias amareladas, mais escurecidas no terço distal. Região ventral do corpo e pernas amareladas.

Cabeça com a superfície lisa. Sutura coronal não atingindo a base do frontoclípeo. Espaço interocelar covexo, espaços ocelo-oculares planos. Lóbulos supra-antenais escavados, com as margens sinuosas. Frontoclípeo piriforme, metade distal com os bordos laterais inteiros e dirigida para baixo.

Pronoto com pontuação heterogênea, não abaulado nas regiões adjacentes às impressões semicirculares, regularmente elevado atrás do espaço entre os processos supra-umerais, gradualmente em declive e afilado para o ápice após o ponto mais elevado e constricto ao nível do ângulo interno das tégminas. Metopídio trapezoidal, com as impressões musculares em forma de $\mathrm{V}$ invertido. Lóbulos pós-oculares com a superfície corrugada, sem modificações ao nível do ângulo externo dos olhos. Sulcos supra-umerais bem marcados, regiões supraumerais com a superfície lisa. Processos supra-umerais desenvolvidos, levemente prismáticos na metade basal e cônicos na metade distal, curvos na metade distal, dirigidos para os lados 


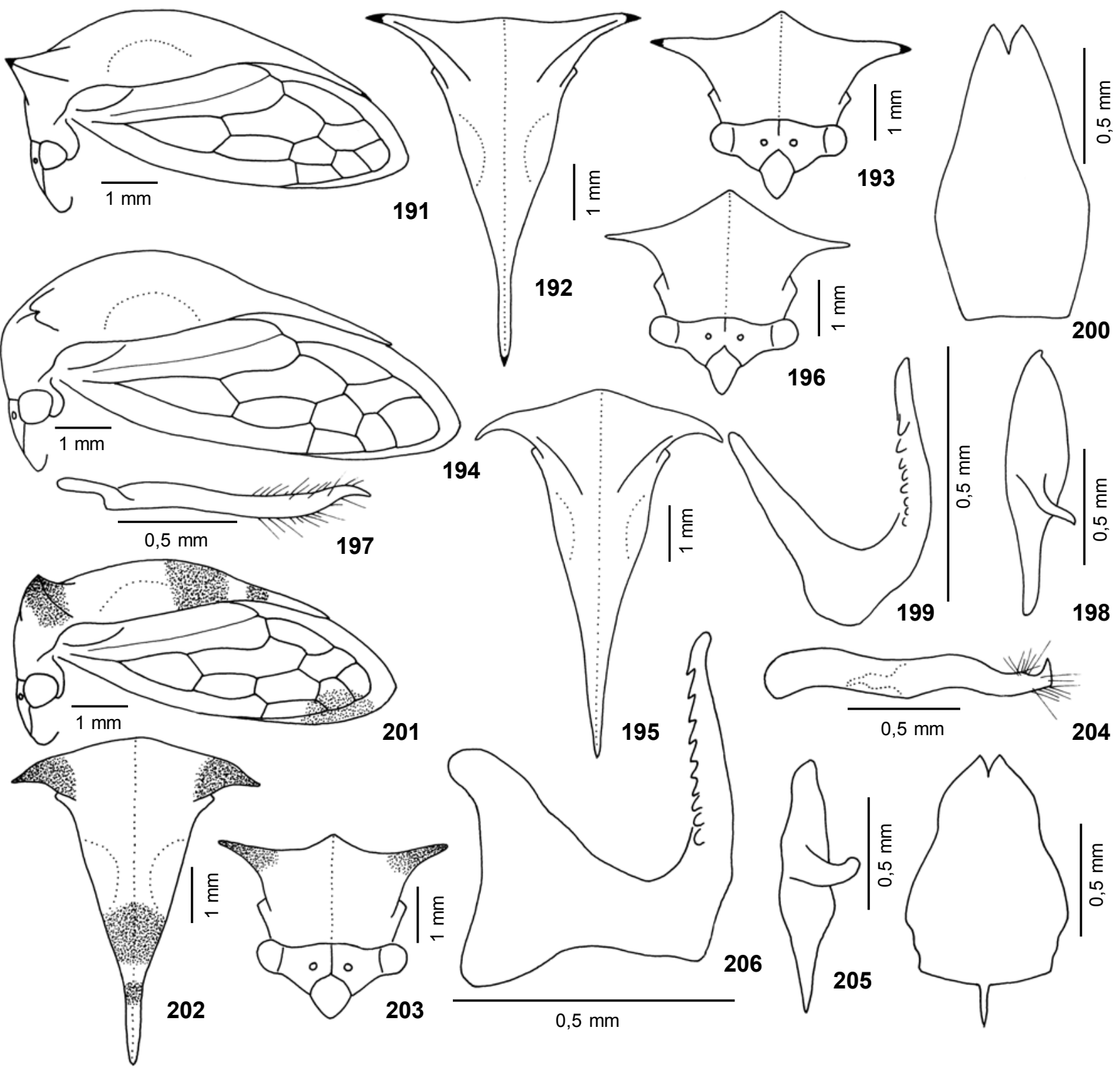

Figuras 191-207. (191-193) Ceresa spinifera: (191) cabeça, pronoto e tégmina, vista lateral; (192) pronoto, vista dorsal; (193) cabeça e pronoto, vista frontal; (194-200) Ceresa viridilineata: (194) cabeça, pronoto e tégmina, vista lateral; (195) pronoto, vista dorsal; (196) cabeça e pronoto, vista frontal; (197) parâmero esquerdo, vista lateral; (198) placa lateral esquerda do pigóforo, vista lateral; (199) edeago, vista lateral; (200) placa subgenital, vista ventral; (201-207) Ceresa fasciatithorax: (201) cabeça, pronoto e tégmina, vista lateral; (202) pronoto, vista dorsal; (203) cabeça e pronoto, vista frontal; (204) parâmero esquerdo, vista lateral; (205) placa lateral esquerda do pigóforo, vista lateral; (206) edeago, vista lateral; (207) placa subgenital, vista ventral.

e para trás, inclinados para baixo e com os ápices voltados para os lados e para trás; face dorsal arredondada, face posterior pontuada na metade basal e lisa na metade distal; espaço entre eles plano; arestas A e P ausentes na metade distal; aresta M pronunciada como um leve intumescimento somente na metade basal; espaço anterior a aresta $\mathrm{M}$ normal, espaço posterior a aresta $\mathrm{M}$ escavado. Impressões semicirculares bem distintas, áreas semicirculares planas e não impressas. Carena dorsal cor- 
tante a partir do ponto mais elevado do pronoto. Ápice atigindo a altura da base da $3^{\text {a }}$ célula apical das tégminas.

Tégminas com a veia R1 originando-se na $2^{\mathrm{a}}$ célula discoidal.

Genitália. Edeago achatado ântero-posteriormente, espatulado na porção apical e com o ápice um pouco curvado para trás; face dorsal com uma fileira de dentículos de cada lado nos dois quartos medianos, um pouco divergentes entre si. Parâmeros subcilíndricos na metade distal, curvados para cima no quarto distal e depois para baixo na porção apical; ápice fusiforme, pouco esclerotinizado, com uma margem pouco cortante na face externa; pilosidade longa e heterogênea esparsamente distribuída ao nível do terço distal, mais abundante na face interna. Placas laterais do pigóforo com o dente apical proeminente, situado no ângulo central; dente lateral desproporcionalmente bem desenvolvido, localizado no terço mediano, diagonalmente dirigido para baixo, com o ápice afilado e curvado também para baixo. Placa subgenital dilatada na região mediana, mais de duas vezes longa que larga basalmente.

Fêmea. Semelhante ao macho, apenas um pouco maior.

Material examinado. Guatemala, Quezaltenango: (?) Quezaltenango, 16.II.1942 (sem coletor), 2 fêmeas (NMNH; ? holótipo e ? alótipo, cf. em Notas sobre os tipos). ColômBia, Cundinamarca: Monterredondo, $1400 \mathrm{~m}$, sem data (sem coletor), 1 macho (MZUSP). Peru, Huánuco: Tingo Maria, Cueva de Las Pavas, 30.I.1984 (L. Huggert), 1 fêmea (LU).

Distribuição geográfica. Guatemala: Quetzeltenango (sic). (Funkhouser 1943). Colômbia: Cundinamarca. Peru: Huánuco.

Localidade-tipo. “...at Quetzeltenango, Guatemala,..." (FunKHouser 1943). Uma etiqueta apensa a cada um dos tipos examinados também tem os dizeres "Quetzel/Guat...", mas não é possível localizar este topônimo. Segundo Selander \& Vaurie (1962), existem na Guatemala o departamento e a cidade com o nome Quezaltenango. Certamente esta é a grafia correta para a indicação de FunkHouser (1943) e é a localidade-tipo da espécie.

Notas sobre os tipos. A série-tipo está confusa. Segundo a descrição original existem o holótipo macho, o alótipo fêmea e dois parátipos fêmeas. Foram obtidos para estudo o holótipo e o alótipo junto ao NMNH, mas o exemplar cujo alfinete porta a etiqueta de holótipo, manuscrita por W.D. Funkhouser, é fêmea. Já o alfinete com a etiqueta de alótipo traz junto uma etiqueta de parátipo, ambas manuscritas também pelo próprio W.D. Funkhouser, e no triângulo onde está colado o exemplar, fêmea, observamos a existência do terceiro par de patas de um outro exemplar, presumivelmente antes montado no mesmo triângulo. Infelizmente, uma consulta adicional ao NMNH não obteve resposta e, assim, somente um estudo conjunto de toda a série-tipo poderia talvez definir se houve engano na referência original ou manipulação posterior.

É oportuno ressaltar que KopP \& YONKE (1979) ilustraram a espécie, inclusive a genitália masculina, sob a legenda “...male, paratype:..." !

Planta hospedeira. Desconhecida.
Comentários. Observamos variações na coloração, principalmente nas tégminas.

Difere das demais espécies notadamente por apresentar os processos supra-umerais bem afilados e com a metade distal nitidamente curvada para trás.

\section{Ceresa fasciatithorax Remes-Lenicov, 1973 Figs 201-207}

Ceresa fasciatithorax Remes-Lenicov, 1973: 119, lám. XXV, figs 186 a 194; McKamey, 1998: 245 (cat.).

Medidas. Macho (holótipo)/fêmea. Largura da cabeça: 2,60/2,88; comprimento da cabeça: $1,30 / 1,44$; distância entre os ângulos umerais: 2,60/2,88; distância entre os ápices dos processos supra-umerais: $4,12 / 4,68$; comprimento do pronoto: 5,58/6,08; comprimento total: 6,67/7,00.

Descrição. Macho. Coloração geral amarelada. Metade distal da face dorsal, face ventral e face posterior dos processos supra-umerais, e duas bandas transversais na região posterior do pronoto, amarronzadas; aresta $\mathrm{M}$ amarelada na metade basal; ápices dos processos supra-umerais e do pronoto negros. Tégminas hialinas, com uma mácula acastanhada ao nível da

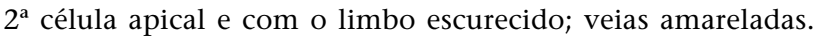
Região ventral do corpo e pernas amareladas.

Cabeça com a superfície fortemente estriada, corrugada no frontoclípeo e nos lóbulos supra-antenais. Sutura coronal atingindo a base do frontoclípeo, mais marcada junto a margem superior. Espaço interocelar convexo, espaços ocelo-oculares deprimidos. Lóbulos supra-antenais planos, com as margens sinuosas. Frontoclípeo sublosângico, metade distal com os bordos laterais chanfrados e dirigida para baixo.

Pronoto com pontuação homogênea, abaulado nas regiões adjacentes às impressões semicirculares, regularmente elevado atrás do espaço entre os processos supra-umerais, gradualmente em declive e afilado para o ápice após o ponto mais elevado e não constricto ao nível do ângulo interno das tégminas. Metopídio trapezoidal, com as impressões musculares em forma de L invertido. Lóbulos pós-oculares com a superfície corrugada, calosos ao nível do ângulo externo dos olhos. Sulcos supra-umerais bem marcados, regiões supraumerais com a superfície pontuada. Processos supra-umerais desenvolvidos, prismáticos, curvos na metade distal, dirigidos para os lados, inclinados para cima e com os ápices voltados para os lados e para trás; face dorsal plana, face posterior pontuada; espaço entre eles convexo; arestas A e P cortantes na metade distal; aresta $\mathrm{M}$ pronunciada em toda a sua extensão; espaços anterior e posterior a aresta $\mathrm{M}$ escavados. Impressões semicirculares pouco distintas, áreas semicirculares planas e não impressas. Carena dorsal cortante a partir do ponto mais elevado do pronoto. Ápice não atingindo a altura da base da $3^{\mathrm{a}}$ célula apical das tégminas.

Tégminas com a veia $\mathrm{R} 1$ originando-se na $2^{\mathrm{a}}$ célula discoidal.

Revista Brasileira de Zoologia 21 (4): 671-738, dezembro 2004 
Genitália. Edeago achatado ântero-posteriormente, com o ápice curvado para trás; face dorsal com uma fileira de dentículos bem desenvolvidos de cada lado, divergentes entre si. Parâmeros contorcidos na região mediana, subcilíndricos e gradualmente afilados na metade distal, curvados para baixo e para dentro no terço distal e abruptamente alargados na porção apical; ápice laminar, mais esclerotinizado, curvado para dentro, ortogonalmente truncado e cortante na porção terminal, e com uma ponta dirigida para cima; pilosidade longa, heterogênea e divaricada, distribuída pré-apicalmente no bordo superior e no ângulo póstero-inferior. Placas laterais do pigóforo com o dente apical obsoleto, situado no ângulo central; dente lateral bem desenvolvido, localizado no terço mediano, curvado para baixo e para trás, com o ápice dilatado e curvado para cima. Placa subgenital glandiforme, quase duas vezes mais longa que larga basalmente.

Fêmea. Semelhante ao macho, apenas um pouco maior. Material examinado. Bolívia, Santa Cruz: Parapeti, X.1960 (A. Martinez), 1 fêmea (MZUSP); Sem indicação de Departamento: sem indicação de localidade, sem data (sem coletor), 1 macho (FCNM; holótipo).

Distribuição geográfica. Bolívia: Santa Cruz.

Localidade-tipo. Bolívia.

Notas sobre os tipos. Segundo a descrição original o holótipo macho estaria depositado no MACNBR, mas foi localizado na FCNM. O exemplar está em razoável estado de conservação, montado em triângulo, com a região ventral da cabeça, do tórax e pernas coladas no triângulo, e com o abdome dissecado. O pronoto tem uma perfuração de alfinete, azinhavrada, ao nível da região anterior à impressão semicircular direita, faltam antenas, pernas I e II esquerdas, tíbia e tarsos III esquerdos, tarso I direito e tíbia e tarso II direitos. Ainda segundo a descrição original, existe o alótipo fêmea também no MACNBR.

Planta hospedeira. Desconhecida.

Comentários. Difere das demais espécies notadamente pelo padrão de coloração.

\section{Ceresa similis Andrade, 1989 Figs 208-214}

Ceresa similis Andrade, 1989: 141, figs 3 e 4, 9 a 12; McKamey, 1998: 246 (cat.).

Medidas. Macho (parátipo)/fêmea (holótipo). Largura da cabeça: 2,76/2,80; comprimento da cabeça: 1,38/1,40; distância entre os ângulos umerais: 2,88/3,04; distância entre os ápices dos processos supra-umerais: 5,50/5,50; comprimento do pronoto: 6,42/6,42; comprimento total: 6,83/6,67.

Descrição. Macho. Coloração geral amarelada. Faces dorsal, ventral e posterior dos processos supra-umerais, espaço entre os processos supra-umerais e uma banda transversal na região posterior do pronoto, amarronzadas; aresta $\mathrm{M}$ amarelada na metade basal; ápices dos processos supra-umerais e do pronoto negros. Tégminas hialinas, veias amareladas. Região ventral do corpo e pernas amareladas.

Cabeça com a superfície fortemente estriada, corrugada no frontoclípeo e nos lóbulos supra-antenais. Sutura coronal atingindo a base do frontoclípeo, mais marcada junto a margem superior. Espaço interocelar convexo, espaços ocelo-oculares deprimidos. Lóbulos supra-antenais planos, com as margens sinuosas. Frontoclípeo sublosângico, metade distal com os bordos laterais chanfrados e dirigida para baixo.

Pronoto com pontuação homogênea, abaulado nas regiões adjacentes às impressões semicirculares, regularmente elevado atrás do espaço entre os processos supra-umerais, gradualmente em declive e afilado para o ápice após o ponto mais elevado e não constricto ao nível do ângulo interno das tégminas. Metopídio trapezoidal, com as impressões musculares em forma de L invertido. Lóbulos pós-oculares com a superfície pontuada, sem modificações ao nível do ângulo externo dos olhos. Sulcos supra-umerais bem marcados, regiões supraumerais com a superfície pontuada. Processos supra-umerais desenvolvidos, prismáticos, curvos na metade distal, dirigidos para os lados, inclinados para cima e com os ápices voltados para os lados e para trás; face dorsal escavada, face posterior pontuada; espaço entre eles convexo; arestas A e P cortantes na metade distal; aresta $\mathrm{M}$ pronunciada em toda a sua extensão; espaços anterior e posterior a aresta $M$ escavados. Impressões semicirculares pouco distintas, áreas semicirculares planas e não impressas. Carena dorsal cortante a partir do ponto mais elevado do pronoto. Ápice ultrapassando a altura da base da $3^{\text {a }}$ célula apical das tégminas.

Tégminas com a veia R1 originando-se na $2^{\mathrm{a}}$ célula discoidal.

Genitália. Edeago subcilíndrico, afilado distalmente, com o ápice curvado para trás; face dorsal com uma fileira de dentículos de cada lado nos dois quartos medianos, um pouco divergentes entre si. Parâmeros subcilíndricos na metade distal e algo intumescidos ao nível do terço distal; ápice laminar, lanceolado, mais esclerotinizado, com uma margem cortante no bordo inferior e a ponta discretamente dirigida para baixo; pilosidade heterogênea distribuída na face interna e nos bordos superior e inferior, ao nível do quarto distal, mais abundante no bordo superior. Placas laterais do pigóforo com o dente apical proeminente, situado no ângulo anterior; dente lateral desproporcionalmente bem desenvolvido, localizado no terço mediano, curvado para baixo e para trás, com o ápice agudo e discretamente curvado para baixo. Placa subgenital glandiforme, uma vez e meia mais longa que larga medianamente.

Fêmea. Semelhante ao macho, apenas um pouco maior.

Material examinado. Brasil, Mato Grosso do Sul: Salobra, III.1940 (Com. Inst. O. Cruz), 1 macho e 1 fêmea (FIOC; parátipos); Bodoquena, III.1940 (Com. Inst. O. Cruz), 1 fêmea (FIOC; holótipo).

Distribuição geográfica. BRASIL: Mato Grosso do Sul (ANDRADE 1989).

Revista Brasileira de Zoologia 21 (4): 671-738, dezembro 2004 
Localidade-tipo. Brasil, Mato Grosso do Sul: Bodoquena.

Notas sobre os tipos. O holótipo fêmea está depositado na FIOC, em bom estado de conservação, alfinetado e com o abdome não dissecado. Faltam antena e tarso I direitos. Existem um parátipo macho e um parátipo fêmea também na FIOC.

Planta hospedeira. Desconhecida.

Comentários. Ao contrário do referido na descrição original, esta espécie é mais semelhante a $C$. fasciatithorax RemesLenicov e não a C. ustulata Fairmaire, por apresentar a veia R1 das tégminas originando-se na $2^{\text {a }}$ célula discoidal e pela similaridade das estruturas da genitália masculina.

Difere dela e das demais espécies notadamente pelo padrão de coloração e pelo aspecto da face dorsal dos processos supra-umerais.

\section{Ceresa rufescens Butler, 1877 sp. rev. Figs 215-221}

Ceresa rufescens Butler, 1877: 218. sp. rev.

Ceresa rufescens; Metcalf \& Wade, 1965: 866 (cat., = C. vitulus

(Fabricius, 1775)); Broomfield, 1971: 373 (tip.); McKamey,

1998: 246 (cat., = C. vitulus (Fabricius, 1775)).

Ceresa alboguttata Remes-Lenicov, 1973: 129, lám. XXIX, figs

220 a 228. syn. nov.

Ceresa alboguttata; McKamey, 1998: 244 (cat.).

Medidas. Macho/fêmea. Largura da cabeça: 2,44/2,72; comprimento da cabeça: 1,22/1,36; distância entre os ângulos umerais: 2,52/2,80; distância entre os ápices dos processos supra-umerais: $4,20 / 4,72$; comprimento do pronoto: $6,42 / 6,67$; comprimento total: 7,75/7,42.

Descrição. Macho. Coloração geral amarelo-escura. Cabeça, metopídio, espaço entre os processos supra-umerais e região posterior do pronoto com máculas esbranquiçadas; margens laterais do pronoto adiante dos ângulos umerais e duas faixas que partem da face posterior dos processos supra-umerais e circundam as áreas semicirculares, esbranquiçadas; ápices dos processos supra-umerais e do pronoto negros. Tégminas hialinas e veias amareladas, mais escurecidas no terço distal. Região ventral do corpo e pernas amareladas.

Cabeça com a superfície fracamente estriada na base e nos espaços ocelo-oculares, lisa nas demais regiões. Sutura coronal não atingindo a base do frontoclípeo. Espaço interocelar convexo, espaços ocelo-oculares planos. Lóbulos supra-antenais escavados, com as margens sinuosas. Frontoclípeo piriforme, metade distal com os bordos laterais inteiros e dirigida para baixo.

Pronoto com pontuação heterogênea, abaulado nas regiões adjacentes às impressões semicirculares, regularmente elevado atrás do espaço entre os processos supra-umerais, gradualmente em declive e afilado para o ápice após o ponto mais elevado e constricto ao nível do ângulo interno das tégminas. Metopídio tapezoidal, com as impressões musculares em forma de V invertido. Lóbulos pós-oculares com a superfície lisa, sem modificações ao nível do ângulo externo dos olhos. Sulcos supra-umerais bem marcados, regiões supra-umerais com a superfície lisa. Processos supra-umerais desenvolvidos, prismáticos, curvos na metade distal, dirigidos para os lados e para trás, inclinados para cima e com os ápices voltados para os lados e para trás; face dorsal arredondada, face posterior pontuada na metade basal e lisa na metade distal; espaço entre eles plano; arestas A e P aparentes na metade distal; aresta M pronunciada em toda a sua extensão, mais intumescida na metade basal; espaço anterior a aresta $\mathrm{M}$ normal, espaço posterior a aresta $\mathrm{M}$ escavado. Impressões semicirculares bem distintas, áreas semicirculares convexas e não impressas. Carena dorsal cortante a partir do ponto mais elevado do pronoto. Ápice atingindo a altura da base da $3^{\text {a }}$ célula apical das tégminas. Tégminas com a veia $\mathrm{R} 1$ originando-se na $2^{\mathrm{a}}$ célula discoidal.

Genitália. Edeago achatado ântero-posteriormente; face dorsal com uma fileira de dentículos de cada lado nos três quintos medianos, ligeiramente divergentes entre si. Parâmeros um pouco achatados lateralmente na metade distal, curvados para cima e para dentro no quarto distal; ápice laminar, espatulado, mais esclerotinizado, com uma margem cortante no bordo inferior; pilosidade longa e esparsa distribuída na face interna, ao nível do quarto distal. Placas laterais do pigóforo com o dente apical proeminente, situado no ângulo central; dente lateral bem desenvolvido, localizado no terço mediano, diagonalmente dirigido para baixo, com o ápice afilado e curvado também para baixo. Placa subgenital quase duas vezes mais longa que larga medianamente, estreitando-se após a região mediana.

Fêmea. Semelhante ao macho, apenas um pouco maior. Material examinado. Brasil. Pernambuco: Caruaru, V.1972 (J.M. Lima), 1 fêmea (DZUP). Minas Gerais: serra do Caraça, Santa Bárbara, I.1971 (F.M. Oliveira), 2 fêmeas (DZUP); Poços de Caldas, campo do Saco, 10.I.1967 (J. Becker, O. Roppa \& O. Leoncini), 1 fêmea (MN); Poços de Caldas, morro do Ferro, 13.I.1967 (J. Becker \& O. Leoncini), 1 sem abdome (MN); Espírito Santo: vale do Itaúnas, ribeirão Engano, IX.X.1944 (Travassos \& N. Santos), 1 macho (FIOC); parque Sooretama, 27.XI.1967 (F. Oliveira), 1 fêmea (DZUP); Linhares, IX.1972 (M. Alvarenga), 1 macho (DZUP); São Paulo: [Boracéia], Estação Biológica, 1942 (sem coletor), 1 fêmea (MZUSP); Barueri, 18.X.1955 (K. Lenko), 1 fêmea (MZUSP); Barueri, 29.V.1966 (K. Lenko), 1 fêmea (MZUSP); Barueri, 5.VI.1966 (K. Lenko), 1 fêmea (MZUSP); São Paulo, 2.I.1965 (F. Wiendl), 1 fêmea (ESALQ); São Paulo, Cantareira, III.1906 (sem coletor), 1 fêmea (MZUSP; identificado como C. vitulus (Fabricius), W.D. Funkhouser det.); São Paulo, Jabaquara, XI.1938 (sem coletor), 1 fêmea (MZUSP); São Paulo, Jabaquara, III.1953 (L. Travassos Filho \& L. Guimarães), 1 macho (MZUSP); Itararé, VIII.1935 (sem coletor), 1 fêmea (MZUSP); Sem indicação de Estado: serra da Bocaina, I.1969 (Alvarenga), 1 fêmea (DZUP); Rio de Janeiro: Teresópolis, XII.1939 (Freitas), 1 fêmea (FIOC); Teresópolis, 2-5.XII.1958 (Martinez, Werner, Alvarenga \& Seabra), 1 macho (DZUP); Par- 


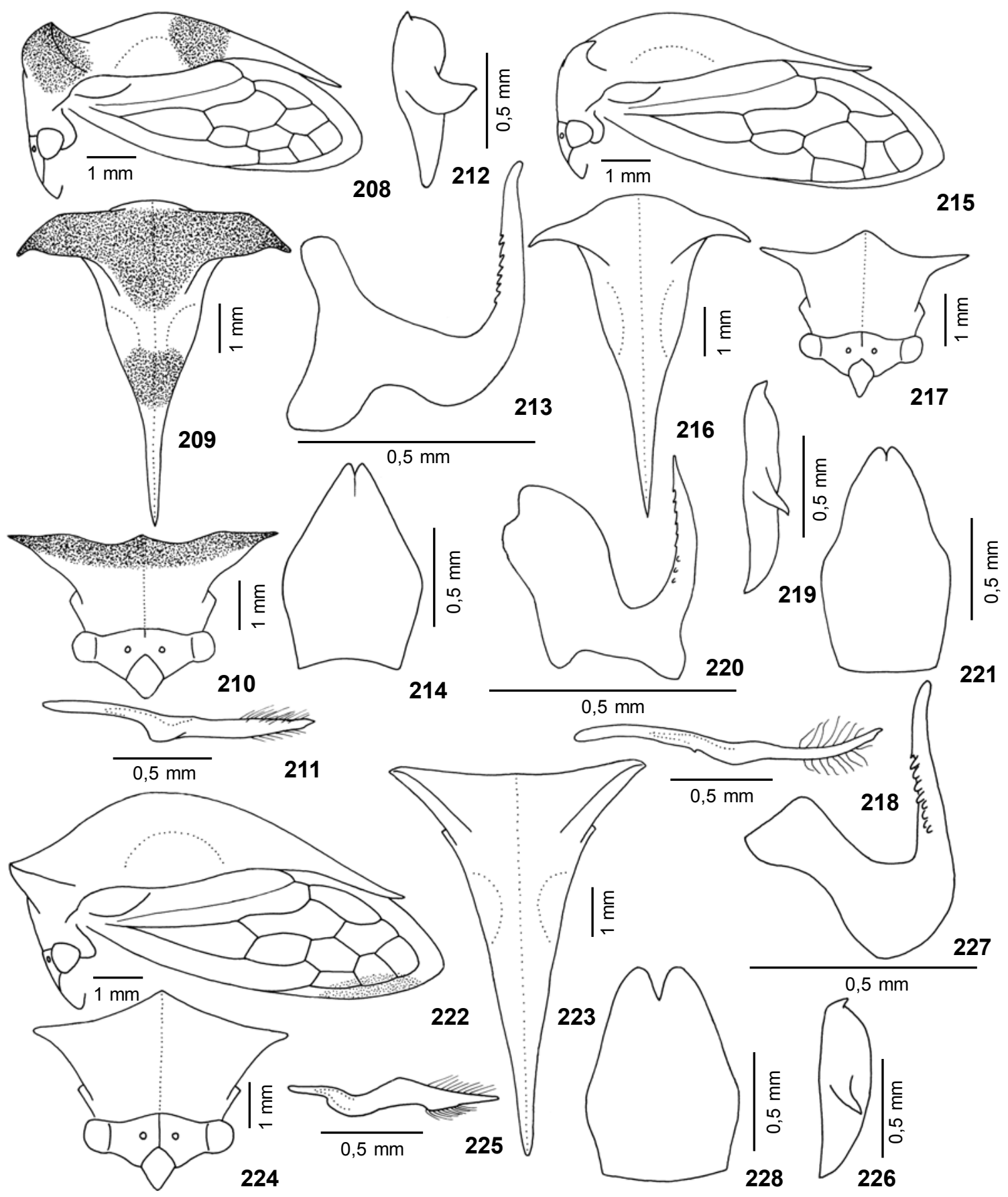

Figuras 208-228. (208-214) Ceresa similis: (208) cabeça, pronoto e tégmina, vista lateral; (209) pronoto, vista dorsal; (210) cabeça e pronoto, vista frontal; (211) parâmero esquerdo, vista lateral; (212) placa lateral esquerda do pigóforo, vista lateral; (213) edeago, vista lateral; (214) placa subgenital, vista ventral; (215-221) Ceresa rufescens: (215) cabeça, pronoto e tégmina, vista lateral; (216) pronoto, vista dorsal; (217) cabeça e pronoto, vista frontal; (218) parâmero esquerdo, vista lateral; (219) placa lateral esquerda do pigóforo, vista lateral; (220) edeago, vista lateral; (221) placa subgenital, vista ventral; (222-228) Ceresa calosa: (222) cabeça, pronoto e tégmina, vista lateral; (223) pronoto, vista dorsal; (224) cabeça e pronoto, vista frontal; (225) parâmero esquerdo, vista lateral; (226) placa lateral esquerda do pigóforo, vista lateral; (227) edeago, vista lateral; (228) placa subgenital, vista ventral. 
que Nacional de Itatiaia, 10.XII.1950 (L. \& H. Travassos), 1 macho (MN); Itatiaia, 700 m, 26.XII.1929 (J.F. Zikán), 1 fêmea (FIOC); Itatiaia, 800 m, VII.1956 (U. Barth), 1 macho e 1 fêmea (MN); Itatiaia, $800 \mathrm{~m}$, XII.? (S. Lopes \& R. Cunha), 1 macho (MZUSP); Resende, 450 m, I.1957 (U. Barth), 1 macho (MN); Rio de Janeiro, Corcovado, 6.X.1967 (Moure \& Seabra), 1 fêmea (DZUP); Rio de Janeiro, Corcovado, IX.1968 (Alvarenga \& Seabra), 1 macho e 1 fêmea (DZUP; o exemplar fêmea identificado como C. vitulus (Fabricius), A.M. Sakakibara det.); Paraná: Astorga, sem data (sem coletor), 1 macho (MZUSP); Quatro Barras, Banhado, 7.II.1970 (Becker \& Laroca), 1 macho (DZUP); Curitiba, 4.IV.1967 (DZUP), 1 fêmea (DZUP); Curitiba, 19.I.1968 (A. Sakakibara), 1 fêmea (DZUP); Curitiba, 9.VI.1973 (A.M. Sakakibara), 1 fêmea (DZUP); Curitiba, 15-27.X.1983 (E.C. Costa), 1 sem abdome e 1 fêmea (DZUP); Morretes, Marumbi, 500 m, à noite, 14.II.1967 (Laroca \& Giacomel), 1 macho (DZUP); Morretes, I.1984 (Sakakibara), 1 macho (DZUP); São José dos Pinhais, 22.XI.1985 (Cavichioli), 1 fêmea (DZUP); Caiobá, 28.III.1964 (R. Lange), 1 fêmea (RBL); Foz do Iguaçu, à noite, lâmpada de mercúrio, 7.XII.1966 (DZUP), 1 macho (DZUP); Santa Catarina: São Bento do Sul, Rio Vermelho, 850 m, 16.III.1974 (Rank), 1 fêmea (DZUP); São Bento do Sul, Rio Vermelho, 850 m, 17.III.1974 (Rank), 2 fêmeas (DZUP); São Bento do Sul, Rio Vermelho, 850 m, 1.IV.1974 (Rank), 1 fêmea (DZUP); São Bento do Sul, 1.VI.1974 (Rank), 1 macho e 1 fêmea (DZUP); Corupá, XII.1951 (A. Maller), 1 fêmea (DZUP); Corupá, III.1953 (A. Maller), 1 fêmea (DZUP); Corupá, IV.1953 (A. Maller), 1 macho (DZUP); Corupá, X.1953 (A. Maller), 1 macho (DZUP); Corupá, XI.1953 (A. Maller), 1 macho e 1 fêmea (DZUP); Corupá, XII.1953 (A. Maller), 6 machos e 5 fêmeas (DZUP); Corupá, I.1954 (A. Maller), 2 machos e 2 fêmeas (DZUP); Corupá, IV.1954 (A. Maller), 1 macho e 1 fêmea (DZUP); Brusque, 20.I.1983 (V.O. Becker), 11 machos e 3 fêmeas (DZUP); Nova Teutônia, 27²11'B, 52²3'L, 21.X.1938 (F. Plaumann), 1 fêmea (LU); Rio Grande do Sul: São Leopoldo, VI.1927 (sem coletor), 1 fêmea (MA); Porto Alegre, 16.VI.1931 (sem coletor), 1 fêmea (MA); Porto Alegre, 20.V.1939 (sem coletor), 1 macho (MZUSP). Argentina, Misiones: Dos de Mayo, 12.XII.1957 (Birabén), 1 fêmea (FCNM: holótipo de C. alboguttata Remes-Lenicov).

Distribuição geográfica. Brasil: Pernambuco, Minas Gerais, Espírito Santo, São Paulo, Rio de Janeiro, Paraná, Santa Catarina e Rio Grande do Sul. Bolívia: Cochabamba e (?) Anazani (RemesLenicov 1973). Argentina: Misiones (Remes-Lenicov 1973).

Localidade-tipo. BRASIL.

Notas sobre os tipos. O holótipo fêmea está depositado no BMNH, em razoável estado de conservação, microalfinetado em suporte de poliestireno, com o abdome não dissecado e superficialmente empoeirado. Faltam antenas e a cabeça está um pouco deslocada à esquerda.

Planta hospedeira. Verbesina sp. (informação de C.F. Varella).

Comentários. FunkHouser (1927b) colocou esta espécie na sinonímia de C. vitulus (Fabricius, 1775). O estudo comparati- vo do holótipo de C. rufescens, depositado no BMNH, com o lectótipo macho de $C$. vitulus, depositado no ZM, mostrou que se tratam de espécies distintas.

O mesmo procedimento com o holótipo fêmea de $C$. alboguttata mostrou que se tratam da mesma espécie.

Foram observadas variações na coloração, principalmente nas máculas e nas tégminas, na inclinação dos processos supra-umerais e no grau de extensão do ápice do pronoto com

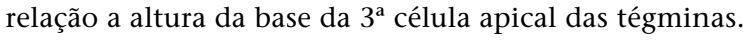

Esta espécie é bem semelhante a $C$. vitulus (Fabricius) e a C. viridilineata Funkhouser. Difere delas e das demais espécies notadamente pela conformação do pronoto.

\section{Ceresa calosa Andrade, 2002 Figs 222-228}

Ceresa calosa Andrade, 2002: 43, figs 3 e 4, 13 a 16.

Medidas. Macho (parátipo)/fêmea (holótipo). Largura da cabeça: 2,64/2,88; comprimento da cabeça: 1,32/1,44; distância entre os ângulos umerais: 2,96/3,08; distância entre os ápices dos processos supra-umerais: 4,92/5,17; comprimento do pronoto: 7,08/7,42; comprimento total: 8,33/8,17.

Descrição. Macho. Coloração geral amarelada, com máculas esbranquiçadas. Aresta M esbranquiçada; ápice do pronoto negro. Tégminas hialinas, com uma mácula acastanhada ao nível das $1^{\mathrm{a}}$ e $2^{\mathrm{a}}$ células apicais; veias amareladas. Região ventral do corpo e pernas amareladas.

Cabeça com a superfície corrugada. Sutura coronal não atingindo a base do frontoclípeo. Espaço interocelar plano, espaços ocelo-oculares planos. Lóbulos supra-antenais planos, com as margens sinuosas. Frontoclípeo sublosângico, metade distal com os bordos laterais inteiros e dirigida para baixo.

Pronoto com pontuação homogênea, não abaulado nas regiões adjacentes às impressões semicirculares, regularmente elevado atrás do espaço entre os processos supra-umerais, gradualmente em declive e afilado para o ápice após o ponto mais elevado e não constricto ao nível do ângulo interno das tégminas. Metopídio trapezoidal, com as impressões musculares em forma de $\mathrm{V}$ invertido. Lóbulos pós-oculares com a superfície lisa, sulcados, calosos e angulosos ao nível do ângulo externo dos olhos. Sulcos supra-umerais pouco marcados, regiões supra-umerais com a superfície pontuada. Processos supra-umerais desenvolvidos, prismáticos, retos na metade distal, dirigidos para frente e para os lados, inclinados para cima e com os ápices voltados para os lados; face dorsal arredondada, face posterior pontuada na metade basal e corrugada na metade distal; espaço entre eles côncavo; arestas A e P aparentes na metade distal; aresta $\mathrm{M}$ pronunciada como um intumescimento em toda a sua extensão; espaços anterior e posterior a aresta M normais. Impressões semicirculares pouco distintas, área semicirculares planas e não impressas. Carena dorsal arredondada a partir do ponto mais elevado do pronoto. Ápice ultrapassando a altura da base da $3^{\text {a }}$ célula apical das tégminas. 
Tégminas com a veia $\mathrm{R} 1$ originando-se na $2^{\mathrm{a}}$ célula discoidal.

Genitália. Edeago achatado ântero-posteriormente, um pouco curvado para trás na porção apical; face dorsal com uma fileira de dentículos bem desenvolvidos de cada lado nos dois quartos medianos, divergentes entre si. Parâmeros achatados lateralmente e gradualmente afilados para o ápice na metade distal, com uma margem cortante no bordo superior e uma margem em destaque no bordo inferior, ao nível do terço distal; ápice afilado, pouco esclerotinizado, curvado para dentro; pilosidade homogênea distribuída no bordo superior e na face interna, ao nível do terço distal, e na margem em destaque do bordo inferior. Placas laterais do pigóforo com o dente apical proeminente, situado no ângulo anterior; dente lateral bem desenvolvido, localizado no terço mediano, afilado e diagonalmente dirigido para baixo. Placa subgenital glandiforme, quase duas vezes mais longa que larga basalmente.

Fêmea. Semelhante ao macho, apenas um pouco maior. Material examinado. BRAsIL, Paraná: Curitiba, IX.1961 (S. Laroca), 1 fêmea (DZUP; holótipo); Curitiba, 900 m, 9.X.1966 (DZUP), 1 fêmea (FCNM; identificado como C. patruelis (sic) Stål, A.M.M. Remes-Lenicov det.); Curitiba, 900 m, 13.XII.1967 (DZUP), 1 fêmea (DZUP; identificado como C. patruelis (sic) Stål, A.M.M. Remes-Lenicov det.); Santa Catarina: Nova Teutônia, $27^{\circ} 11^{\prime} \mathrm{B}, 52^{\circ} 23^{\prime} \mathrm{L}, 300-500$ m, V.1975 (F. Plaumann), 1 macho (DZUP; identificado como Vestistilus sp., D.D. Kopp det.); Rio Grande do Sul: Canela, 6.II.1962 (P. Buck), 1 fêmea (MA); Porto Alegre, 20.IV.1938 (P. Buck), 1 macho (MA). (Todos os exemplares examinados pertencem à série-tipo).

Distribuição geográfica. Brasil: Paraná (Remes-Lenicov 1973), Santa Catarina e Rio Grande do Sul (ANDRAde 2002).

Localidade-tipo. Brasil, Paraná: Curitiba.

Notas sobre os tipos. O holótipo fêmea está depositado na DZUP, em perfeito estado de conservação, alfinetado e com o abdome não dissecado. Existem um parátipo fêmea na FCNM, um parátipo macho e um parátipo fêmea no MA, e um parátipo macho e um parátipo fêmea também na DZUP.

Planta hospedeira. Desconhecida.

Comentários. Foram observadas variações na extensão da mácula acastanhada das tégminas.

Difere das demais espécies notadamente por apresentar os lóbulos pós-oculares nitidamente sulcados, calosos e angulosos ao nível do ângulo externo dos olhos.

\section{Ceresa chacoana Remes-Lenicov, 1973} Figs 229-235

Ceresa chacoana Remes-Lenicov, 1973: 111, lám. XXII, figs 159 a 167; McKamey, 1998: 244 (cat.).

Medidas. Macho (holótipo)/fêmea (alótipo). Largura da cabeça: 2,88/3,00; comprimento da cabeça: 1,44/1,50; distância entre os ângulos umerais: 3,00/3,04; distância entre os ápices dos processos supra-umerais: 4,64/4,76; comprimento do pronoto: 7,08/7,50; comprimento total: 7,92/8,17.

Descrição. Macho. Coloração geral ferruginosa, mais escurecida no metopídio, no espaço entre os processos supraumerais e na face ventral dos processos supra-umerais. Porção distal das faces dorsal, ventral e posterior dos processos supraumerais negra; faixa ao longo das margens laterais do pronoto amarelada; ápice do pronoto negro. Tégminas hialinas, com uma mácula acastanhada ao nível das $1^{\mathrm{a}}, 2^{\mathrm{a}}$ e $3^{\mathrm{a}}$ células apicais; veias acastanhadas. Região ventral do corpo e pernas ferruginosas.

Cabeça com a superfície estriada, com algumas pontuações, corrugada no frontoclípeo e nos lóbulos supra-antenais. Sutura coronal atingindo a base do frontoclípeo, mais marcada junto a margem superior. Espaço interocelar convexo, espaços ocelo-oculares planos. Lóbulos supra-antenais planos, com as margens sinuosas. Frontoclípeo piriforme, metade distal com os bordos laterais inteiros e dirigida para baixo.

Pronoto com pontuação homogênea, não abaulado nas regiões adjacentes às impressões semicirculares, fracamente elevado atrás do espaço entre os processos supra-umerais, levemente em declive e afilado para o ápice após o ponto mais elevado e não constricto ao nível do ângulo interno das tégminas. Metopídio trapezoidal, com as impressões musculares em forma de L invertido. Lóbulos pós-oculares com a superfície corrugada, sulcados e calosos ao nível do ângulo externo dos olhos. Sulcos supra-umerais bem marcados, regiões supra-umerais com a superfície pontuada. Processos supra-umerais desenvolvidos, prismáticos, curvos na metade distal, dirigidos para os lados, inclinados para cima e com os ápices voltados para os lados e para trás; face dorsal arredondada, face posterior pontuada na metade basal e corrugada na metade distal; espaço entre eles convexo; arestas A e P cortantes na metade distal; aresta M pronunciada em toda a sua extensão; espaços anterior e posterior a aresta $\mathrm{M}$ escavados. Impressões semicirculares pouco distintas, áreas semicirculares planas e não impressas. Carena dorsal arredondada a partir do ponto mais elevado do pronoto, cortante apenas em sua porção distal. Ápice atingindo a altura da base da $3^{\text {a }}$ célula apical das tégminas. discoidal.

Tégminas com a veia $\mathrm{R} 1$ originando-se na $2^{\mathrm{a}}$ célula

Genitália. Edeago achatado ântero-posteriormente, notadamente na porção apical; face dorsal com uma fileira de dentículos de cada lado, divergentes entre si e unindo-se próximo ao ápice. Parâmeros achatados lateralmente na metade distal, um pouco intumescidos ao nível do quarto distal e curvados para dentro na porção apical; ápice laminar, mais esclerotinizado, com uma margem cortante no bordo superior; pilosidade longa e homogênea distribuída na face interna, ao nível do quarto distal. Placas laterais do pigóforo com o dente apical proeminente, situado no ângulo central; dente lateral bem desenvolvido, localizado no terço mediano, diagonalmente dirigido para baixo e com o ápice arredondado. Placa subgenital uma vez e meia mais longa que larga basalmente, estreitando-se após a região mediana.

Revista Brasileira de Zoologia 21 (4): 671-738, dezembro 2004 
Fêmea. Semelhante ao macho, apenas um pouco maior. Material examinado. Brasil, Bahia: Caravelas, 23.VI.1969 (J. Becker), 7 machos e 1 fêmea (MN); Minas Gerais: Passos, IX.1963 (C. \& T. Elias), 1 fêmea (DZUP; parátipo); Passos, 712.X.1963 (C. Elias), 1 fêmea (DZUP; parátipo); Passos, 49.XI.1963 (C. Elias), 1 fêmea (DZUP; parátipo); São Paulo: Bebedouro, 26.IV.1938 (A. Silva), 1 fêmea (MZUSP); Rio de Janeiro: Duque de Caxias, São Bento, VI.1954 (P.A. Teles), 1 macho (DZUP); Rio de Janeiro, Guaratiba, II.1956 (J.H. Guimarães), 1 macho e 2 fêmeas (FIOC). Argentina, Misiones: Concepción, Santa María, V.1944 (M.J. Viana), 1 fêmea (FCNM; alótipo); Concepción, Santa María, X.1947 (M.J. Viana), 1 macho (FCNM; holótipo).

Distribuição geográfica. Brasil: Minas Gerais (Remes-Lenicov 1973), Bahia, São Paulo e Rio de Janeiro. Argentina: Chaco, Misiones e Neuquén (Remes-Lenicov 1973).

Localidade-tipo. Argentina, Misiones: Concepción, Santa María.

Notas sobre os tipos. O holótipo macho está depositado na FCNM, em bom estado de conservação, montado em cartão, com a região ventral da cabeça, do tórax e as pernas coladas no cartão, e com o abdome não dissecado. Faltam os flagelos antenais e o tarso I direito. Segundo a descrição original, existem o alótipo fêmea (examinado), dois parátipos machos e um parátipo fêmea também na FCNM, quatro parátipos machos e dois parátipos fêmeas no MACNBR e um parátipo macho e três parátipos fêmeas na DZUP (apenas os três parátipos fêmeas foram localizados e examinados).

Planta hospedeira. Desconhecida.

Comentários. Foram observadas variações na coloração, principalmente na extensão da mácula acastanhada das tégminas, na inclinação dos processos supra-umerais e no grau de extensão do ápice do pronoto com relação a altura da base da $3^{\text {a }}$ célula apical das tégminas.

Difere das demais espécies notadamente pelo padrão de coloração e pela conformação falciforme dos processos supraumerais.

\section{Ceresa remeslenicovae Andrade, 2002 Figs 236-242}

Ceresa remeslenicovae Andrade, 2002: 48, figs 7 e 8, 21 a 24 .

Medidas. Macho (holótipo)/fêmea (parátipo). Largura da cabeça: 2,56/2,76; comprimento da cabeça: 1,36/1,44; distância entre os ângulos umerais: 2,60/2,88; distância entre os ápices dos processos supra-umerais: $4,32 / 4,92$; comprimento do pronoto: 6,08/6,42; comprimento total: 7,17/7,50.

Descrição. Macho. Coloração geral amarelada, com máculas esbranquiçadas no metopídio e no espaço entre os processos supra-umerais. Porção apical das faces dorsal, ventral e posterior dos processos supra-umerais negra; regiões ao longo da aresta $\mathrm{P}$, regiões adjacentes à carena dorsal a partir do espaço entre os processos supra-umerais e, notadamente, o processo pronotal posterior, acastanhados; duas faixas que partem da face posterior dos processos supra-umerais e circundam as áreas semicirculares, esbranquiçadas; ápice do pronoto negro. Tégminas hialinas, com escurecimento nas células apicais e no limbo; veias amareladas. Região ventral do corpo e pernas amareladas.

Cabeça com a superfície estriada na base e nos espaços ocelo-oculares, lisa nas demais regiões. Sutura coronal atingindo a base do frontoclípeo, mais marcada junto à margem superior. Espaço interocelar convexo, espaços ocelo-oculares planos. Lóbulos supra-antenais escavados, com as margens sinuosas. Frontoclípeo piriforme, metade distal com os bordos laterais inteiros e dirigida para baixo.

Pronoto com pontuação homogênea, não abaulado nas regiões adjacentes às impressões semicirculares, regularmente elevado atrás do espaço entre os processos supra-umerais, gradualmente em declive e afilado para o ápice após o ponto mais elevado e constricto ao nível do ângulo interno das tégminas. Metopídio trapezoidal, com as impressões musculares em forma de $\mathrm{V}$ invertido. Lóbulos pós-oculares com a superfície corrugada, sem modificações ao nível do ângulo externo dos olhos. Sulcos supra-umerais bem marcados, regiões supraumerais com a superfície pontuada. Processos supra-umerais desenvolvidos, prismáticos, curvos na metade distal, dirigidos para os lados, inclinados para baixo e com os ápices voltados para os lados e para trás; face dorsal arredondada, face posterior pontuada na metade basal e lisa na metade distal; espaço entre eles plano; arestas A e P cortantes na metade distal; aresta $\mathrm{M}$ pronunciada na metade distal e apenas intumescida na metade basal; espaço anterior a aresta $\mathrm{M}$ normal, espaço posterior a aresta $\mathrm{M}$ escavado. Impressões semicirculares pouco distintas, áreas semicirculares planas e não impressas. Carena dorsal cortante a partir do ponto mais elevado do pronoto. Ápice atingindo a altura da base da $3^{\mathrm{a}}$ célula apical das tégminas.

Tégminas com a veia $\mathrm{R} 1$ originando-se na $2^{\mathrm{a}}$ célula discoidal.

Genitália. Edeago subcilíndrico, um pouco curvado para trás na porção apical; face dorsal com uma fileira de dentículos de cada lado nos dois quartos medianos, um pouco divergentes entre si. Parâmeros subcilíndricos, gradualmente afilados para o ápice, curvados um pouco para fora e para cima ao nível do terço distal; ápice fusiforme, mais esclerotinizado, curvado para dentro; pilosidade longa e esparsa distribuída ao longo do bordo superior do terço distal, e em menor quantidade na face interna e no bordo inferior da porção apical. Placas laterais do pigóforo com o dente apical proeminente, situado no ângulo anterior; dente lateral bem desenvolvido, localizado no terço mediano, curvado para baixo e para trás, com o ápice afilado e discretamente curvado para baixo. Placa subgenital dilatada na região mediana, mais de duas vezes longa que larga basalmente.

Fêmea. Semelhante ao macho, apenas um pouco maior. Material examinado. BRASIL, Mato Grosso: Chapada dos Guimarães, 23.XI.1983 (Exc. Dep. Zool. UFPR, Polonoroeste), 1 macho (DZUP); Chapada dos Guimarães, "malaise", 1-3.XII.1983 

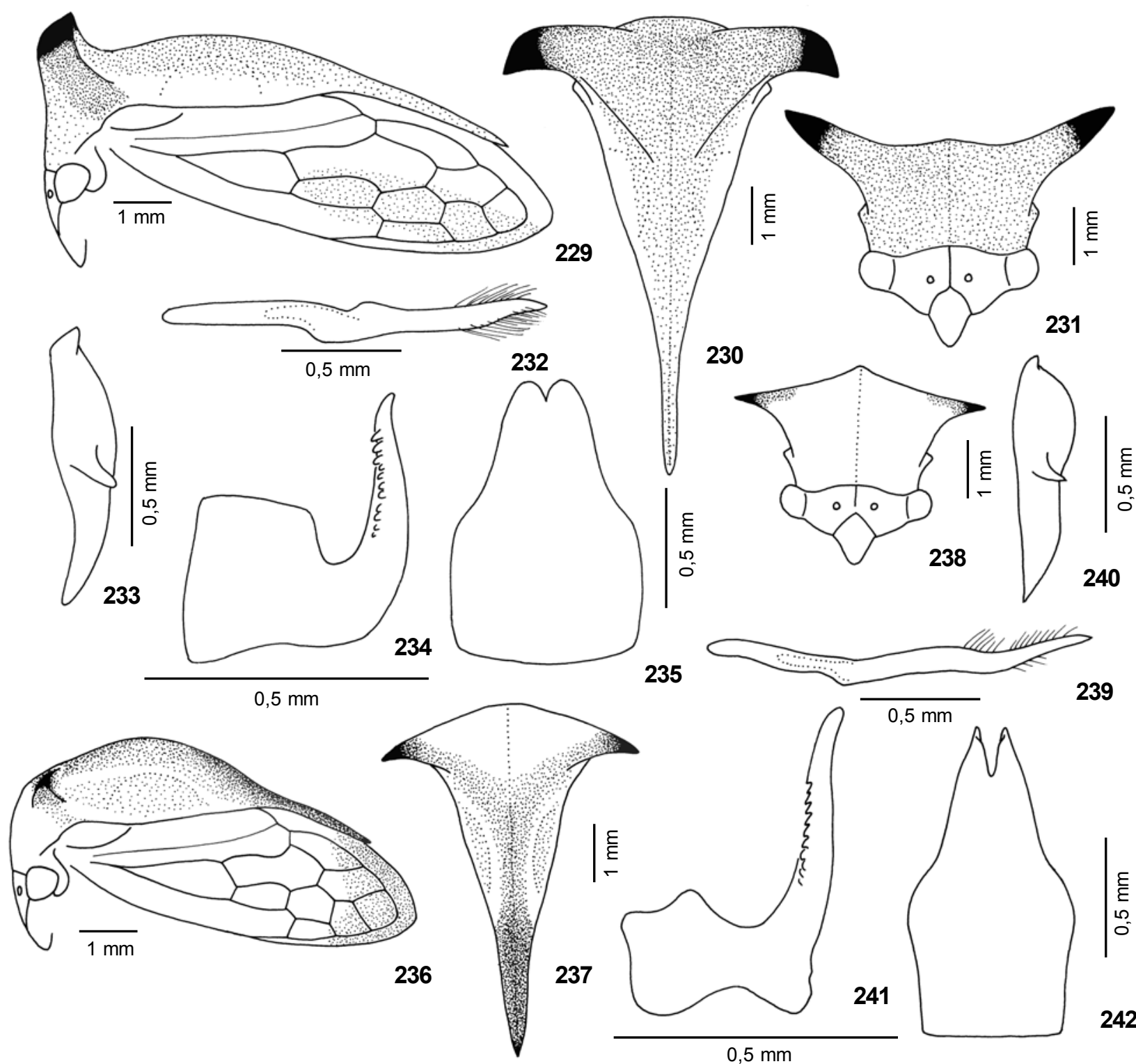

Figuras 229-242. (229-235) Ceresa chacoana: (229) cabeça, pronoto e tégmina, vista lateral; (230) pronoto, vista dorsal; (231) cabeça e pronoto, vista frontal; (232) parâmero esquerdo, vista lateral; (233) placa lateral esquerda do pigóforo, vista lateral; (234) edeago, vista lateral; (235) placa subgenital, vista ventral; (236-242) Ceresa remeslenicovae: (236) cabeça, pronoto e tégmina, vista lateral; (237) pronoto, vista dorsal; (238) cabeça e pronoto, vista frontal; (239) parâmero esquerdo, vista lateral; (240) placa lateral esquerda do pigóforo, vista lateral; (241) edeago, vista lateral; (242) placa subgenital, vista ventral.

(Exc. Dep. Zool. UFPR, Polonoroeste), 1 fêmea (DZUP); Minas Gerais: Santa Vitória, II.1970 (F.M. Oliveira), 2 machos e 8 fêmeas (DZUP; um macho identificado como C. integra Walker, G.S. Andrade det.); Sete Lagoas, IPEACO, 13.III.1974 (V.O. Becker), 2 machos (DZUP); Sete Lagoas, IPEACO, 10.IV.1974 (V.O. Becker), 2 machos (DZUP); Sete Lagoas, IPEACO, 15.IV.1974 (V.O. Becker), 2 machos (DZUP); Passos, 28.V.1962 (C. Elias), 1 fêmea (DZUP; identificado como C. integra Walker, A.M.M. Remes-Lenicov det.); Passos, 21-26.VI.1962 (C. Elias), 1 macho (DZUP; identificado como C. integra Walker, A.M.M. Remes-Lenicov det.); Passos, 510.VII.1962 (C. Elias), 1 fêmea (DZUP; identificado como C. integra Walker, A.M.M. Remes-Lenicov det.); Passos, 11-17.VII.1962 (C. Elias), 1 fêmea (DZUP; identificado como C. integra Walker, A.M.M. Remes-Lenicov det.); Passos, 12-17.XI.1962 (C. Elias), 1

Revista Brasileira de Zoologia 21 (4): 671-738, dezembro 2004 
fêmea (DZUP; identificado como C. integra Walker, A.M.M. Remes-Lenicov det.); Passos, 10-15.XII.1962 (C. Elias), 1 fêmea (DZUP; identificado como C. integra Walker, A.M.M. RemesLenicov det.); Alpinópolis, II.1961 (C. Elias), 1 fêmea (DZUP; identificado como C. integra Walker, A.M.M. Remes-Lenicov det.); Nova Rezende, VII.1961 (C. Elias), 1 macho e 2 fêmeas (DZUP; identificado como C. integra Walker, A.M.M. Remes-Lenicov det.); Cataguases, III.1985 (G.S. Andrade), 1 fêmea (DZUP); Mato Grosso do Sul: Rio Brilhante, à luz, 25.I.1971 (V.O. Becker), 1 fêmea (DZUP); Espírito Santo: Córrego do Itá, XII.1981 (B. Silva), 1 fêmea (CACS); São Paulo: Ribeirão Prêto, 17.XII.1975 (M. Mazucato), 1 fêmea (FMRP); Ilha Seca, 19-26.II.1940 (Com. Inst. O. Cruz), 1 fêmea (FIOC); Rio Claro, V.1940 (sem coletor), 1 fêmea (MZUSP); Piracicaba, EECJV, 540 m, "light trap", 3.XII.1965 (sem coletor), 1 macho (ESALQ); Piracicaba, ESALQ, 540 m, "light trap", 13.XII.1965 (Neto \& Wiendl), 1 fêmea (ESALQ); Piracicaba, ESALQ, 540 m, "light trap", 28.II.1966 (Neto \& Wiendl), 1 macho (DZUP; holótipo); Piracicaba, ESALQ, 540 m, "light trap", 7.III.1966 (Neto \& Wiendl), 1 fêmea (ESALQ); Campinas, 15.IV.1938 (H.F.G. Sauer), 2 machos (MZUSP); Campinas, 27.VI.1939 (H.F.G. Sauer), 1 macho (MZUSP); Campinas, UNICAMP, sem formigas, em Panicum maximum, 1.III.1982 (B.C. Lopes), 1 fêmea (BCL); Campinas, UNICAMP, em Solanum sp., 5.XII.1983 (B.C. Lopes), 1 fêmea (BCL); Barueri, 18.II.1966 (K. Lenko), 1 fêmea (MZUSP); Itararé, XII.1935 (E. Sch.), 1 fêmea (IB); Bocaiúva, VI.1935 (A.L. Amadio), 1 macho (MZUSP); Paraná: Porto Mendes, XII.1941 (Com. E.N.V.), 1 fêmea (FIOC); Santa

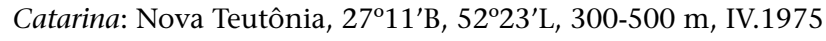
(F. Plaumann), 1 fêmea (DZUP). BolívIA, Santa Cruz: Santa Cruz de la Sierra, II.1958 (Monrós), 1 fêmea (FML; identificado como C. integra Walker, A.M.M. Remes-Lenicov det.). Paraguai, Central: Asunción, 13.I.1962 (Sakagami \& S. Laroca), 1 fêmea (DZUP; identificado como C. integra Walker, A.M.M. Remes-Lenicov det.). ARgentina, Jujuy: Jujuy, 1.IV.1911 (P. Jörgensen), 1 macho (FCNM; identificado como C. integra Walker, A.M.M. Remes-Lenicov det.); Chaco: Chaco, $30 . I I I .1931$ (J.A.R. Costa), 1 fêmea (FCNM; identificado como C. integra Walker, A.M.M. Remes-Lenicov det.); Tucumán: Tucumán, XI.1946 (Córdoba), 1 fêmea (FML; identificado como C. integra Walker, A.M.M. Remes-Lenicov det.). Todos os exemplares examinados pertencem à série-tipo.

Distribuição geográfica. BRAsil: Paraná (Remes-Lenicov 1973), Mato Grosso, Minas Gerais, Mato Grosso do Sul, Espírito Santo, São Paulo e Santa Catarina (Andrade 2002). Bolívia: Santa Cruz (Remes-Lenicov 1973). Paraguai: Central (Andrade 2002). Argentina: Jujuy, Salta, Chaco, Misiones, Corrientes e Córdoba (Remes-Lenicov 1973) e Tucumán (ANDRAde 2002).

Localidade-tipo. Brasil, São Paulo: Piracicaba.

Notas sobre os tipos. O holótipo macho está depositado na DZUP, em razoável estado de conservação, alfinetado e com o abdome dissecado. O pronoto está um pouco solto, a tégmina direita está aberta e falta a perna II direita. Existem dois parátipos fêmeas na coleção BCL, um parátipo fêmea na coleção CACS, um parátipo macho e dois parátipos fêmeas na ESALQ, um parátipo macho e um parátipo fêmea na FCNM, dois parátipos fêmeas na FIOC, dois parátipos fêmeas na FML, um parátipo fêmea na FMRP, dois parátipos machos e um parátipo fêmea no IB, quatro parátipos machos e três parátipos fêmeas no MZUSP e doze parátipos machos e vinte e dois parátipos fêmeas também na DZUP.

Plantas hospedeiras. Panicum maximum e Solanum sp. (observações de B.C. Lopes).

Comentários. Foram observadas variações na coloração, na escultura da superfície da cabeça, às vezes mais amplamente estriada, e na inclinação dos processos supra-umerais.

É oportuno ressaltar que, dentre todas as espécies reconhecidas, esta é a única a apresentar os lóbulos apicais da placa subgenital dos machos envolvendo a porção apical dos parâmeros, o que pode ser observado mesmo sem a dissecção do abdome dos exemplares.

Difere das demais espécies notadamente pelo padrão de coloração.

\section{Ceresa jugifera Goding, 1929 nom. dub.}

[Ceresa jugifera] Stoll, 1788: 36, pl. 6, figs 32 e $a$. nom. dub.

Ceresa jugifera Goding, 1929: 260; Metcalf \& wade, 1965: 864 (cat., = C. colon (Germar, 1835)); McKamey, 1998: 244 (cat., = C. colon (Germar, 1835)).

GodiNg (1929) assumiu inadvertidamente a autoria deste binômio, ao fazer indicação a descrição e ilustrações de STOLL (1788), colocando em sua sinonímia C. colon (Germar, 1835), C. puncticeps Stål, 1864 e C. pauperata Berg, 1884 (sic).

Este lapso não foi percebido por FunKhouser (1951) que, embora tenha listado C. colon e C. puncticeps como espécies distintas, e $C$. pauperata na sinonímia de $C$. extensa Walker, admitiu C. jugifera como sendo de autoria de STOLL (1788).

Metcalf \& Wade (1965) consideraram C. puncticeps e $C$. jugifera como sinônimos de C. colon, mantendo entretanto $C$. pauperata na sinonímia de $C$. extensa, em consonância com FunKHOUSER (1927b).

Ceresa pauperata é espécie distinta, a situação taxonômica de C. extensa foi esclarecida por SaKakibara (2002), a de C. colon por Andrade (2004a) e a de C. puncticeps por Andrade (2004b), mas $C$. jugifera, entretanto, não pode ter sua posição sistemática e identidade esclarecidas.

Buscas à material-tipo desta espécie foram infrutíferas. É possível que esteja depositado no "Rijksmuseum van Natuurlijke Histoire", em Leiden.

\section{Ceresa conica Sakakibara, 1977 incertae sedis}

Ceresa conica Sakakibara, 1977: 33, figs 8 a 11; McKamey, 1998: 244 (cat.).

Esta espécie apresenta caracteres do pronoto e das estruturas da genitália masculina comuns também ao gênero Paraceresa Kopp \& Yonke, 1979, necessitando estudos adicionais para precisar sua posição sistemática. 


\section{Vestistilus affinis (Fairmaire, 1846) comb. nov.}

Ceresa affinis Fairmaire, 1846: 284, pl. V, figs 21 e 22; Metcalf \& Wade, 1965: 843 (cat.); McKamey, 1998: 244 (cat.).

\section{CONCLUSÕES}

Dentre os vários aspectos abordados ao longo do trabalho, merecem destaque os pertinentes ao dimorfismo sexual, à coloração, aos caracteres da morfologia externa, às estruturas da genitália masculina e à distribuição geográfica.

Com exceção de C. atrata Remes-Lenicov, que requer estudos complementares, a única discrepância observada quando indivíduos de ambos os sexos de uma mesma espécie são confrontados é o tamanho. Como regra, geralmente as fêmeas apresentam maiores proporções.

A coloração merece consideração especial. Embora a maioria das espécies apresente coloração praticamente uniforme, existem casos em que são observados padrões peculiares de coloração, sendo esta característica então o suficiente para distinguir uma dada espécie entre as demais. Entretanto, em ambos os casos, é importante ter em mente que métodos diferentes de coleta, sacrificação e preservação de exemplares, e a idade in vivo e in vitro dos mesmos, podem influenciar a expressão desta característica.

Dos caracteres da morfologia externa utilizados, ainda que seja constatado que possam apresentar variações individuais, alguns são mais confiáveis e são abordados a seguir. A cabeça tem na sua escultura as melhores características para diferenciar as espécies. Já no pronoto merecem menção a conformação geral, o padrão de pontuação, a escultura dos lóbulos pós-oculares, a aparência dos sulcos e regiões supra-umerais, a conformação dos processos supra-umerais e a aparência da carena dorsal. A variabilidade observada no grau de inclinação, curvatura e extensão das extremidades do pronoto pode ser razoavelmente entendida se levado em consideração que condições climáticas diferentes no momento de emergência dos imagos das ninfas, podem influenciar no processo de distensão e endurecimento do pronoto. As tégminas tem como bom caráter somente a posição da veia R1, variável apenas em C. cavicornis Stål. As demais veias e células das tégminas não mostram caracteres que possam ser utilizados com clareza nas descrições, ocorrendo variações inclusive entre as tégminas de um mesmo indivíduo.

O montante de estruturas da genitália masculina examinado corrobora as colocações de CALDWELl (1949) sobre os caracteres mais relevantes: “...The form and size of the apical portion of the styles [parâmeros] and the form and location of the teeth on the lateral valves are perhaps the most significant specific characters. The aedeagus is usually slightly different in each form, and in some groups it is sufficiently distinct for specific placement.".

A distribuição geográfica do gênero Ceresa é confirmada como estritamente Neotropical, cuja área de ocorrência das espécies foi constatada desde o departamento de Quezaltenango na Guatemala até a província de Río Negro na Argentina. Embora o presente estudo amplie bastante a área de distribuição conhecida de algumas espécies, outras continuam registradas apenas pela localidade-tipo, às vezes vagamente indicada, o que dificulta estudos de escopo biogeográfico e reflete claramente a escassez de coletas representativas em muitas áreas da região Neotrópica.

\section{AGRADECIMENTOS}

Ao Prof. Dr. Albino Morimasa Sakakibara, pela orientação, apoio e estímulos durante o desenvolvimento de meus estudos. Pelas sugestões, informações, fornecimento ou empréstimo de bibliografia, traduções, confecção ou empréstimo de fotografias de tipos, comparação de exemplares com os tipos, empréstimo de tipos ou de material para estudo, a M.C. Almeida (Universidade Federal do Paraná, Curitiba, Brasil), N.M. Andersen (Zoologisk Museum, København, Denmark), U. Aspöck (Naturhistorisches Museum Wien, Wien, Osterreich), J. Becker (Museu Nacional, Rio de Janeiro, Brasil), C. Bordón (Maracay, Venezuela), M. Boulard (Museum National d'Histoire Naturelle, Paris, France), A.D. Brisolla (Instituto Biológico, São Paulo, Brasil), P.S. Broomfield (The Natural History Museum, London, United Kingdon), J.M.F. Camargo (Faculdade de Medicina de Ribeirão Preto, Ribeirão Preto, Brasil), C.J.B. Carvalho (Universidade Federal do Paraná, Curitiba, Brasil), G.S. Carvalho (Pontifícia Universidade Católica do Rio Grande do Sul, Porto Alegre, Brasil), J.C.M. Carvalho (Museu Nacional, Rio de Janeiro, Brasil), A. Casale (Museo Regionale di Scienze Naturali, Torino, Italia), R. Danielsson (Lunds Universitet, Lund, Sweden), L.L. Deitz (North Carolina State University, Raleigh, United States of America), O.V. Ferreira (Fundação Instituto "Osvaldo Cruz", Rio de Janeiro, Brasil), P.S.F. Ferreira (Universidade Federal de Viçosa, Viçosa, Brasil), R.C. Froeschner (National Museum of Natural History, Washington, United States of America), C. Garcia (San Miguel de Tucumán, Argentina), U. GöllnerScheiding (Museum für Naturkunde der Humboldt-Universität zu Berlin, Berlin, Deutschland), J. Grazia (Universidade Federal do Rio Grande do Sul, Porto Alegre, Brasil), C.M.F. von Hayek (The Natural History Museum, London, United Kingdon), E.R. Hoebke (Cornell University, Ithaca, United States of America), D.S. (Woody) Horning, Jr. (The MacLeay Museum, Sydney, Australia), A. Kedziorek (Warzawa, Poland), D.D. Kopp (North Dakota State University, Fargo, United States of America), L. Krieger (Centro de Ensino Superior de Juiz de Fora, Juiz de Fora, Brasil), R.B. Lange (Curitiba, Brasil), S. Laroca (Universidade Federal do Paraná, Curitiba, Brasil), J.K. Liebherr (Cornell University, Ithaca, United States of America), B.C. Lopes (Florianópolis, Brasil), P.W. Lozada (Museo de Historia Natural "Javier Prado", Lima, Peru), U.R. Martins (Museu de Zoologia da Universidade de São Paulo, São Paulo, Brasil), S.H. McKamey (National Museum of Natural History, Washington, United States

Revista Brasileira de Zoologia 21 (4): 671-738, dezembro 2004 
of America), O.H.H. Mielke (Universidade Federal do Paraná, Curitiba, Brasil), M.A. Monné (Museu Nacional, Rio de Janeiro, Brasil), J.S. Moure (Universidade Federal do Paraná, Curitiba, Brasil), J.R.P. Parra (Escola Superior de Agricultura "Luiz de Queiroz", Piracicaba, Brasil), C.M. Penz (Museu Anchieta, Porto Alegre, Brasil), J.A. Rafael (Instituto Nacional de Pesquisas da Amazônia, Manaus, Brasil), J.A. Ramos (Universidad de Puerto Rico, Mayagüez, Puerto Rico), R.A. Ronderos (Facultad de Ciencias Naturales y Museo, La Plata, Argentina), A.M. Sakakibara (Universidade Federal do Paraná, Curitiba, Brasil), C.A.C. Seabra (Rio de Janeiro, Brasil), S.A. Slipinski (Polska Akademia Nauk, Warszawa, Poland), C.A.D. Teixeira (Embrapa/Cenargen, Brasília, Brasil), R.T. Thompson (The Natural History Museum, London, United Kingdon), M.V.A. Toledo (Fundacion "Miguel Lillo", San Miguel de Tucumán, Argentina), F.C. do Val (Museu de Zoologia da Universidade de São Paulo, São Paulo, Brasil), P.E. Vanzolini (Museu de Zoologia da Universidade de São Paulo, São Paulo, Brasil), C.F. Varella (Florianópolis, Brasil) e a M.D. Webb (The Natural History Museum, London, United Kingdon). Aos professores do Departamento de Zoologia da Universidade Federal do Paraná e aos colegas do curso de pós-graduação em Entomologia da mesma Universidade, pelos ensinamentos, companheirismo, críticas e sugestões. Ao Prof. Dr. Germano Henrique Rosado Neto, do Departamento de Zoologia da Universidade Federal do Paraná, pela "carona" amiga. Ao Governo do Estado de Minas Gerais, na pessoa dos Excelentíssimos Senhores Governadores Hélio Garcia e Newton Cardoso, pela concessão e manutenção da autorização especial para frequentar o curso de pós-graduação em Entomologia da Universidade Federal do Paraná. Ao Conselho Nacional de Desenvolvimento Científico e Tecnológico (CNPq) e à Coordenação de Aperfeiçoamento de Pessoal de Nível Superior (CAPES), pelas bolsas concedidas. Aos revisores, Albino Morimasa Sakakibara e Gabriel Mejdalani, e à Comissão Editorial desse periódico, por valiosas sugestões para a versão final do trabalho. Aos que acompanharam o trabalho, em especial Márcia Pinheiro de Andrade, por sua compreensão e colaboração para com minhas lides entomológicas.

\section{REFERÊNCIAS BIBLIOGRÁFICAS}

Amyot, C.J.B. \& A. Serville. 1843. Histoire Naturelle des Insectes. Hémiptères. Paris, Libraire Encyclopedique de Roret, $676 \mathrm{p}$.

ANDRADE, G.S. 1989. Duas novas espécies do gênero Ceresa Amyot \& Serville, 1843 (Homoptera: Membracidae). Anais da Sociedade Entomológica do Brasil, Porto Alegre, 18 (Supl.): 139-145.

. 1997. Stictocephala alta (Walker,1851) sp. rev., comb. nov., the correct name for the "buffalo treehopper", with $S$. bisonia Kopp \& Yonke, 1977 as a new synonym, and notes on Hadrophallus bubalus (Fabricius, 1794) comb. nov. (Homoptera: Membracidae). Transactions of the American
Entomological Society, Philadelphia, 123 (4): 289-295. . 1999a. Nomenclatural and taxonomic notes on Alcmeone robusta (Butler) comb. nov. (Hemiptera, Auchenorrhyncha, Membracidae). Revista Brasileira de Zoologia, Curitiba, 16 (1): 267-268.

- 1999b. Nomenclatural and taxonomic notes on Proranus intractus (Walker) comb. rev. (Hemiptera, Auchenorrhyncha, Cicadellidae). Revista Brasileira de Zoologia, Curitiba, 16 (1): 269.

. 1999c. Nota nomenclatural sobre Amastris stali Fowler, nom. nud. (Hemiptera, Auchenorrhyncha, Membracidae). Revista Brasileira de Zoologia, Curitiba, 16 (1): 271.

. 2002. Sobre quatro novas espécies de Ceresa Amyot \& Serville (Hemiptera, Auchenorrhyncha, Membracidae). Revista Brasileira de Zoologia, Curitiba, 19 (suplemento 2): 39-51.

. 2003. Vestistiloides, um novo gênero de Ceresini (Hemiptera, Auchenorrhyncha, Membracidae). Revista Brasileira de Zoologia, Curitiba, 20 (1): 1-2.

- 2004a. Contribuições ao conhecimento do gênero Paraceresa Kopp \& Yonke (Hemiptera, Auchenorrhyncha, Membracidae). Revista Brasileira de Zoologia, Curitiba, 21 (1): 39-41.

. 2004b. Novas combinações e sinonímia em Spissistilus Caldwell (Hemiptera, Auchenorrhyncha, Membracidae). Revista Brasileira de Zoologia, Curitiba, 21 (1): 43-44.

Berg, C. 1879. Hemiptera Argentina (Continuación). Anales de la Sociedad Cientifica Argentina, Buenos Aires, 8: 209 226.

. 1883. Addenda et emendanda ad Hemiptera Argentina (Continuatio). Anales de la Sociedad Cientifica Argentina, Buenos Aires, 16: 285-294.

Broomfield, P.S. 1971. A catalogue of the Membracid types (Homoptera: Membracidae) in the British Museum (Natural History). Bulletin of the British Museum of Natural History (Entomology), London, 25 (8): 325-386.

BUTLER, A.G. 1877. On various genera of the homopterous family Membracidae with descriptions of new species. Cistula Entomologica, London, 2: 205-222.

Caldwell, J.S. 1949. A generic revision of the treehoppers of the tribe Ceresini in America north of Mexico, based on a study of the male genitalia. Proceedings of the United States National Museum, Washington, 98: 491-521.

CASAle, A. 1981. Cataloghi II - Collezione Emitterologica di Massimiliano Spinola. Torino, Museo Regionale di Scienze Naturali, 120p.

Casolari, C. \& R. Casolari Moreno. 1980. Cataloghi I - Collezione Imenotterologica di Massimiliano Spinola. Torino, Museo Regionale di Scienze Naturali, 165p.

Deitz, L.L. 1975. Classification of the higher categories of the New World treehoppers (Homoptera: Membracidae). North Carolina Agricultural Experiment Station Technical Bulletin, Raleigh, 225: 1-177. 
1989. Bibliography of the Membracoidea (Homoptera: Aetalionidae, Biturritiidae, Membracidae, and Nicomiidae) 1981-1987. North Carolina Agricultural Research Service Technical Bulletin, Raleigh, 290: 1-31.

DeitZ, L.L. \& D.D. Kopp. 1987. Bibliography of the Membracoidea (Homoptera: Aetalionidae, Biturritiidae, Membracidae, and Nicomiidae) 1956-1980. North Carolina Agricultural Research Service Technical Bulletin, Raleigh, 284: 1-39.

Dennis, C.J. 1952. Genitalia of the Membracidae of Wisconsin. Canadian Entomologist, Guelph, 84 (6): 157-173.

. 1960. The genitalia of the buffalo treehopper, Stictocephala bubalus (Fabricius). American Midland Naturalist, Notre Dame, Indiana, 64 (2): 459-473.

FABRICIUS, J.C. 1775. Systema entomologiae, sistens insectorum classes, ordines, genera, species adiectis synonymis, locis, descriptionibus, observationibus. Flensburgi et Lipsiae, 832p.

. 1794. Entomologia systematica emendata et aucta 4. Hafniae, 472p.

Fairmaire, L.M.H. 1846. Revue de la tribu des Membracides. Annales de la Société Entomologique de France, Paris, 4: 235-320.

Fowler, W.W. 1895. Order Rhynchota. Suborder HemipteraHomoptera, p. 89-112. In: F.D. Godman \& O. Salvin (Eds). Biologia Centrali-Americana, vol. 2.

FunKHOUSER, W.D. 1914. Report on a collection of Membracidae from the Colombian Andes, taken by Mr. John Thomas Lloyd. Journal of the New York Entomological Society, New York, 22: 275-281.

- 1927a. General catalogue of the Hemiptera. Fascicle I: Membracidae. Northampton, Smith College, $581 \mathrm{p}$.

. 1927b. New Membracidae collected by the Cornell South American Expedition. Journal of the New York Entomological Society, New York, 35: 159-164.

. 1943. Membracidae of Guatemala. Annals of the Entomological Society of America, Columbus, 36: 455482.

. 1951. Homoptera Fam. Membracidae. Genera Insectorum, Bruxelles, 208: 1-383.

Germar, E.F. 1835. Species Membracidum Musae E.F. Germari. Revue Entomologique, Strasbourg, 3: 223-262.

Goding, F.W. 1893. Bibliographical and synonymical catalogue of the described Membracidae of North America. Bulletin of the Illinois State Laboratory of Natural History 3: 391482 .

. 1929. The Membracidae of South America and the Antilles. IV. Subfamilies Hoplophorioninae, Darninae, Smiliinae, Tragopinae (Homoptera). Transactions of the American Entomological Society, Philadelphia, 55: 197330.

. 1930. Membracidae in the American Museum of Natural History. American Museum Novitates, New York, 421:
$1-27$.

Horn, W. \& I. Kahle. 1935-1937. Über entomologische Sammlungen, Entomologen und Entomo-Museologie. Entomologische Beihefte aus Berlin-Dahlem, Berlin, 2-4: 1-536.

Kopp, D.D. \& T.R. YonkE. 1974. Willian D. Funkhouser (18811948 ) bibliography and a list of names proposed. Entomological News, Philadelphia, 85 (5-6): 131-145.

. 1977. Taxonomic status of the buffalo treehopper and the name Ceresa bubalus (Fabricius). Annals of the Entomological Society of America, Columbus, 70 (6): 901905.

1979. A taxonomic review of the tribe Ceresini (Homoptera: Membracidae). Miscellaneous Publications of the Entomological Society of America, College Park, 11 (2): 1-97.

Lawson, P.B. 1922. The Membracidae of Kansas (Homoptera). University of Kansas Science Bulletin, Lawrence, 14: 27110.

Lichtenstein, A.A.H. 1796. Catalogus musei Zoologici ditissimi Hamburgi, d III. Februar 1796. Auctionis lege distrahendi. Sectio Tertia. Continens Insecta. Hamburg, G.F. Schniebes, 224p.

McKamey, S.H. 1997. Nomenclatural changes in the Membracidae and Aetalionidae (Hemiptera: Membracoidea): speciesgroup names and Sphongophorus Fairmaire, revised status. Steenstrupia, Copenhagen, 22: 1-11.

. 1998. Taxonomic Catalogue of the Membracoidea (Exclusive of Leafhoppers) - Second Supplement to Fascicle 1 - Membracidae of the General Catalogue of the Hemiptera. Memoirs of the American Entomological Institute, Gainesville, 60: 1-377.

METCALF, Z.P. \& V. WADE. 1965. General catalogue of the Homoptera. A supplement to Fascicle I - Membracidae of the General catalogue of Hemiptera. Membracoidea. In two sections. Raleigh, North Carolina State University, 1552p.

PAPAVERO, N. 1971-1973. Essays on the history of neotropical dipterology, with special reference to collectors (17501905). São Paulo, Museu de Zoologia, Universidade de São Paulo, 2 vols.

- 1994. Fundamentos Práticos de Taxonomia Zoológica. Coleções, Bibliografia, Nomenclatura. São Paulo, Editora UNESP, $2^{\text {a }}$ ed., 285p.

Remes-Lenicov, A.M.M. 1973. Contribución al estudio de los Membrácidos neotropicales I. Revisión del género "Ceresa" (sic) Amyot et Serville. Acta Zoologica Lilloana, Tucuman, 30: 53-134.

- 1976. Adiciones a la fauna neotropical de Ceresa Amyot et Serville, 1843 (Insecta, Homoptera, Membracidae). Neotropica, La Plata, 22 (67): 45-49.

SAKAKIBARA, A.M. 1977. Duas espécies novas de Ceresa Amyot \& Serville (Homoptera, Membracidae). Revista Brasileira de Biologia, Rio de Janeiro, 37 (1): 31-34. 2002. Revalidation of Ilithucia Stål and descriptions 
of new species (Homoptera, Membracidae, Smiliinae). Revista Brasileira de Zoologia, Curitiba, 19 (1): 189-200.

Selander, R.B. \& P. Vaurie. 1962. A gazetteer to accompany the "Insecta" volumes of the Biologia Centrali Americana. American Museum Novitates, New York, 2099: 1-70.

STÅL, C. 1859. Hemiptera. Species novas descripsit. In: Kongliga Svenska Vetenskaps-AKademien. 1857-1900. Kongliga svenska fregatten Eugenies resa omkring jorden under befäl af C.A. Virgin aren 1851-1853. Stockholm, P.A. Norstedt \& Söner, 3 vols.

. 1867. Bidrag till Hemipterernas systematik. Öfversigt af Kongliga Svenska Vetenskaps-Akademiens Förhandlingar, Stockholm, 24: 491-560.

. 1869a. Hemiptera Fabriciana. Fabricianska Hemipterarter, efter de i Köpenhamn och Kiel förvarade typexemplaren granskade och beskrifne. 2. Kongliga Svenska Vetenskaps-Akademiens Förhandlingar, Stockholm, 8 (1): 1-130. . 1869b. Bidrag till Membracidernas kannedom.

Öfversigt af Kongliga Svenska Vetenskaps-Akademiens
Förhandlingar, Stockholm, 1869: 231-300.

STOLL, C. 1788. Natuurlyke en Naar't Leeven Naauwkeurig Gekleurde Afbeeldingen en Beschryvingen der Cicaden, in alle vier waerelds deelen Europa, Asia, Africa en America Huishoudende. Amsterdam, B.J.C. Sepp., 124p.

ToRres, B.A. 1946. Homopteros (Auquenorrincos) perjudiciales en nuestro país. Boletin do Laboratorio de Zoologia Agricola, La Plata, 9: 1-38.

WALKER, F. 1851. List of the specimens of homopterous insects in the collection of the British Museum. London. 2: 261636.

. 1858a. Insecta saundersiana: or characteres of undescribed insects in the collection of William Wilson Saunders, Esq. Homoptera. London, J.V. Voorst. 117p.

. 1858b. List of the specimens of homopterous insects in the collection of the British Museum. London, Supplement, 307p.

Zimzen, E. 1964. The type material of I.C. Fabricius. Copenhagen, Munksgaard, 656p.

Recebido em 12.VIII.2003; aceito em 23.X.2004. 